\title{
O ZONEAMENTO E O TERRITÓRIO DO TERCIARIO NA CIDADE DE CAMPINAS
}

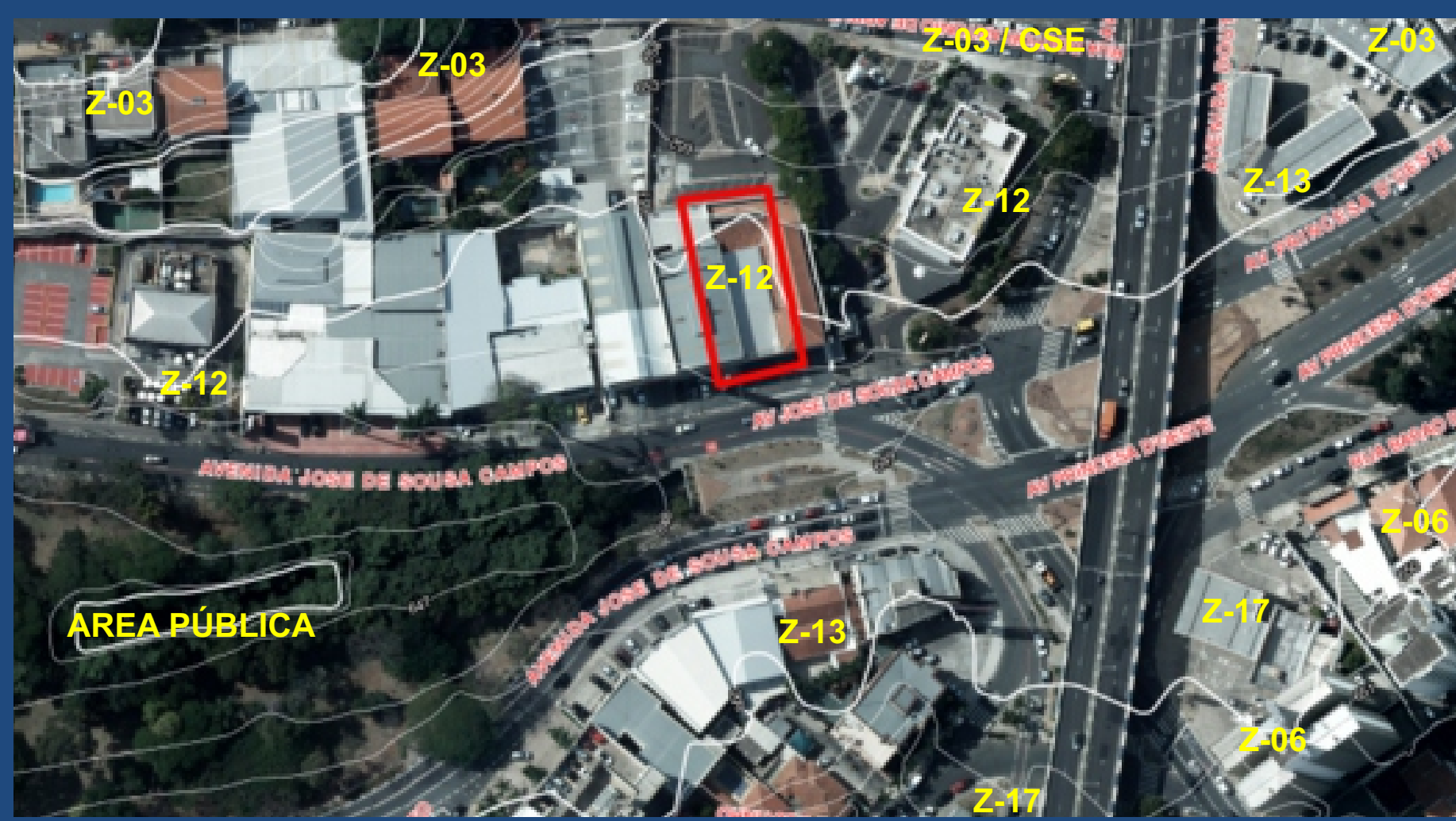

Faculdade de Arquitetura e Urbanismo da Universidade de São Paulo 
O ZONEAMENTO E O TERRITÓRIO DO TERCIÁRIO NA CIDADE DE CAMPINAS

Dissertação à

Faculdade de Arquitetura e Urbanismo da Universidade de São Paulo para a obtenção do título de Mestre em Arquitetura e Urbanismo

Área de Concentração:

Planejamento Urbano e Regional

Linha de Pesquisa: Políticas Públicas

Orientação: Prof $^{a} \operatorname{Dr}^{\mathrm{a}}$ Heliana Comin Vargas

São Paulo

2016

AUTORIZO A REPRODUÇÃO E DIVULGAÇÃO TOTAL OU PARCIAL DESTE TRABALHO, POR QUALQUER MEIO CONVENCIONAL OU ELETRÔNICO, PARA FINS DE ESTUDO E PESQUISA, DESDE QUE 


\section{CITADA A FONTE.}

E-MAIL DO AUTOR: gardela@uol.com.br

Juliano, Marcelo Alexandre

J94z O zoneamento e o território do terciário na cidade de Campinas / Marcelo Alexandre Juliano. -- São Paulo, 2016.

175 p. : il.

Dissertação (Mestrado - Área de Concentração: Planejamento Urbano e Regional) - FAUUSP.

Orientadora: Heliana Comin Vargas

1.Zoneamento - Campinas (SP) 2.Setor terciário 3.Planejamento territorial urbano I.Título 

Aos meus filhos, Isabelle e Marcelo, à minha esposa Adriana, e às cidades, maior invenção do gênero humano. 


\section{Agradecimentos:}

Inicialmente, gostaria de agradecer à Professora Heliana pela dedicada orientação, por sua disponibilidade, paciência e generosidade em compartilhar seus conhecimentos;

Aos professores da FAU, pelos ensinamentos, pela busca do rigor científico e pelas discussões proveitosas nestes três anos;

Aos funcionários da FAU pela gentileza e presteza na disponibilização das informações e no atendimento de minhas solicitações;

À Banca de qualificação, composta pelos professores Maria Beatriz Cruz Rufino e Eugênio Fernandes Queiroga, pelos apontamentos e observações que muito contribuíram para o desenvolvimento deste trabalho;

Aos colegas da Secretaria Municipal de Educação da Prefeitura Municipal de Campinas e aos meus chefes, a Arquiteta Fabiane S. Mariotto Dal Fabbro, o Diretor do DAE, Dr. Maurilei Pereira e a Secretária Municipal de Educação, Solange V. Pellicer, que generosamente contribuíram para que eu pudesse obter os créditos;

Aos colegas da Secretaria Municipal e Planejamento e Desenvolvimento Urbano (SEPLAN), ao Secretário Fernando Vaz Pupo, e aos colegas do Depto. de Informação, Documentação e Cadastro pelas informações e dados disponibilizados;

Ao Centro de Documentação da Rede Anhanguera de Comunicação, pelo acesso ao acervo de fotos e reportagens.

À Coordenadoria Setorial do Patrimônio Cultural, CSPC, e aos colegas Conselheiros do CONDEPACC, pelo apoio e disponibilidade, a quem agradeço nas pessoas dos Historiadores Daisy Ribeiro e Henrique Anunziata;

À família Brásio, pela gentileza em me receber, pela paciência em esclarecer dúvidas, e pela disponibilização de documentos do acervo familiar;

Aos moradores, ex-moradores, e proprietários de empresas situadas na Nova Campinas com quem tive oportunidade de conversar, em especial ao Eng. ${ }^{\circ}$ Raul Garcia Jr., ao Dr. João Rocha e ao Sr. Antônio De Lucca.

Ao presidente da Câmara Municipal de Campinas, Vereador Rafa Zimbaldi, que gentilmente me franqueou o acesso aos arquivos da Câmara.

Aos Arquitetos Onofre dos Santos Jr. e Márcia Barbin, pelo auxílio no tratamento de imagens e mapas.

À minha esposa Adriana, e aos meus filhos Isabelle e Marcelo, agradeço por sua compreensão e paciência nas várias noites e finais de semana, em que fiquei sem poder Ihes dedicar a merecida atenção, por estar pesquisando ou escrevendo este texto, entretido nos livros e materiais de pesquisa. 
"Classified telephone directories tell us the greatest single fact about cities: the immense numbers of parts that make up a city, and the immense diversity of those parts. Diversity is natural to big cities."

"As listas telefônicas classificadas nos contam o mais importante fato sobre as cidades: o número imenso de partes que compõem uma cidade, e a enorme diversidade destas partes. Diversidade é algo natural para as grandes cidades."

Jane Jacobs, The death and life of great American cities, 1961.p.187 


\section{RESUMO:}

JULIANO, Marcelo. O Zoneamento e o território do terciário na cidade de Campinas. 2016. Dissertação de Mestrado - Faculdade de Arquitetura e Urbanismo, Universidade de São Paulo, São Paulo, 2016.

Decorridos 14 anos da promulgação do Estatuto das Cidades, com todos seus instrumentos de intervenção no território, o zoneamento ainda permanece como a principal ferramenta de planejamento de nossas cidades. É o grande foco das disputas entre os diversos atores e seus interesses, que agem na produção do espaço urbano. No Brasil, este instrumento recebeu a influência do "zoning" norte-americano que, agindo basicamente na proteção e valorização do modelo de habitação singular, segrega os demais usos, que seriam supostamente incompatíveis com a habitação. Com as mudanças econômicas a partir dos anos 70 , o setor terciário assume posição de destaque na economia dos grandes centros, a reboque do novo modo de produção flexível, passando a evidenciar novas formas de consumo que, juntamente com as facilidades de transporte e comunicação, promovem outras dinâmicas no uso do espaço urbano e outras manifestações locacionais. Estas dinâmicas, próprias da inserção do setor terciário no tecido urbano, se chocam com um modelo de ordenamento do território inspirado nas premissas do urbanismo funcional modernista do IV CIAM, explicitadas na Carta de Atenas, e no "zoning" norte-americano. Ao mesmo tempo em que herdamos esta cultura de planejamento, focada no zoneamento, nunca tivemos a capacidade institucional (e tampouco a vontade política) para garantir sua aplicação efetiva. Este modelo encontrará numa sociedade de raiz patrimonialista (acostumada à cultura do jeitinho, do privilégio e do tráfico de influência), um viés diverso do norte-americano, muito mais sujeito aos interesses dos detentores do poder ou dos grupos com capacidade econômica e força política para negociar em prol de seus interesses específicos. Apesar deste regramento restritivo, o setor terciário representa uma parcela cada vez maior, na geração de riqueza e de postos de trabalho nas grandes cidades. Ele busca as oportunidades locacionais, de acordo com a disponibilidade e viabilidade para cada atividade. E, onde a legislação demonstra defasagem com a dinâmica urbana, o setor terciário vai se instalar, com os seus agentes buscando (politicamente, quando possível) as adequações nesta legislação, ou então simplesmente ignorando-a. O presente trabalho, servindo-se do exemplo da cidade de Campinas/SP, procura demonstrar a inadequação do modelo de zoneamento restritivo, como principal ferramenta de ordenação do território, em especial quanto à distribuição espacial das atividades do setor terciário.

Palavras-chave: Campinas, zoneamento, setor terciário, planejamento territorial urbano. 


\begin{abstract}
:
After 14 years of the enactment of the Statute of the City, with all its instruments of intervention in the territory, the zoning remains as the main planning tool for our cities. It is the major focus of disputes between the various actors and their interests, which act in the production of urban space. In Brazil, this instrument has received the influence of "American zoning" which acting primarily in the protection and enhancement of the single-family housing model, segregate other uses, which were supposed to be incompatible with. With the economic changes from the $70 \mathrm{~s}$, the tertiary sector assumes a prominent position in the economy of the major centers, the trailer of the new flexible production mode, starting to show new forms of consumption which, together with transport and communication facilities, promote other dynamics in the use of urban space and other locational demonstrations. These dynamics, proper insertion of the tertiary sector in the urban fabric, collide with a spatial model of the territory inspired by the premises of modernist functional urbanism of the IV CIAM, embedded in the Charter of Athens, and in the "American zoning". While we have inherited this culture of planning, focused on zoning, never had the institutional capacity (nor the political will) to ensure its effective implementation. This model will find a patrimonialism rooted society (used to knack culture of privilege and influence peddling), a diverse bias of the United States, far more subject to the interests of those in power or groups with economic power and political power to negotiate on behalf of their specific interests. Despite this restrictive codes, the tertiary sector accounts for an increasing share in the generation of wealth and jobs in big cities. It seeks the locational opportunities, according to the availability and feasibility for each activity. And where legislation demonstrates gap with urban dynamics, the tertiary sector will be installed with its agents seeking (politically, if possible) the adjustments in this legislation, or simply ignoring it. This work, drawing on the example of the city of Campinas / $\mathrm{SP}$, seeks to demonstrate the inadequacy of the restrictive zoning model as the main sorting tool of the territory, in particular concerning the spatial distribution of the activities of the tertiary sector.
\end{abstract}

Keywords: Campinas, zoning, tertiary sector, urban land planning. 


\section{LISTA DE ILUSTRAÇÕES:}

Figura 1 Mapa do $1^{\circ}$ Plano compreensivo de zoneamento (Frankfurt, 1891). fl. 27

Figura 2 Modelo alemão genérico proposto de cidade autossustentável.

fl. 33

Figura 3 Modelo alemão genérico de bairro autossustentável.

fl. 33

Figura 4 Projeto alemão de habitação social do período 1900-1910.

fl. 33

Figura 5 Projeto alemão de habitação social do período 1900-1910.

fl. 33

Figura 6 Siedlung Römerstadt de 1927 (projeto).

fl. 34

Figura 7 Foto residência Ernst May.

fl. 34

Figura 8 Siedlung Römerstadt de 1927 (foto aérea anos 30). fl. 34

Figura 9 Siedlung Hohenblick (1926). fl. 35

Figura 10 Siedlung Riedhof West (1927-32). fl. 35

Figura 11 Mapa de zoneamento de parte da ilha de Manhattan conforme a fl. 39 Zoning Ordinance Law de Nova York (1916).

Figura 12 Equitable Building e o princípio do setback.

fl. 40

Figura 13 O padrão "Bolo de noiva".

Figura 14 Cartoon promovendo o zoning (Atlanta, 1922).

fl. 43

Figura 15 Cartoon promovendo o zoning (Evansville, 1929).

fl. 43

Figura 16 Terciário em via residencial: Av. Jesuíno Marcondes Machado.

fl. 53

Figura 17 Terciário em via residencial: Av. Jesuíno Marcondes Machado.

fl. 53

Figura 18 Empreendimento no Eixo da Rod. D. Pedro I: Hipermercado. fl. 55

Figura 19 Empreendimento no Eixo da Rod. D. Pedro I: Shopping center. fl. 55

Figura 20 Rua 13 de Maio - eixo de comércio popular. fl. 57

Figura 21 Rua 13 de Maio - eixo de comércio popular. fl. 57

Figura 22 "The Mall”, shopping de conveniência. fl. 59

Figura 23 "The Mall”, shopping de conveniência. fl. 59

Figura 24 Agência Bancária em área residencial. fl. 60

Figura 25 Mapa de Campinas em $1900 . \quad$ fl. 67

Figura 26 Mapa de Campinas em $1929 . \quad$ fl. 68

Figura 27 Área urbanizada de Campinas até a década de $1950 . \quad$ fl. 72

Figura 28 Foto aérea circa $1955 . \quad$ fl. 73

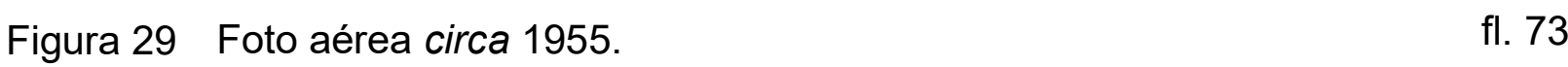

Figura 30 Mapa da evolução da mancha urbana de Campinas. fl. 76 
Figura 31 Megalópole do Sudeste brasileiro.

fl. 82

Figura 32 Rodovias no território de Campinas.

fl. 83

Figura 33 Modelo de projeto simplificado com módulos comerciais.

fl. 93

Figura 34 A Nova Campinas e a área urbanizada até 1940.

fl. 104

Figura 35 Avenidas perimetrais do plano de Prestes Maia.

fl. 105

Figura 36 Loteamento Vila Nova Campinas (1939).

fl. 106

Figura 37 A Nova Campinas (perímetro sobre imagem de satélite).

fl. 108

Figura 38 Ficha de Habite-se imóvel Rua Carlos Stevenson.

Figura 39 Distribuição das datas de ocupação de imóveis da rua Carlos Stevenson por década.

Figura 40 Distribuição das datas de ocupação de imóveis da rua Dr. Hermas Braga.

Figura 41 Igreja Santa Rita de Cássia circa 1980.

Figura 42 Igreja Santa Rita de Cássia em 2015.

Figura 43 Guarita de vigilância e viatura de segurança particular.

Figura 44 Áreas de concentração de condomínios e loteamento fechados e áreas de favelas e ocupações.

Figura 45 Padrão de ocupação no entorno dos shopping centers.

Figura 46 Eixo econômico metropolitano - corredor Rod. D. Pedro I.

Figura 47 Nova Campinas - zoneamento em 1988.

Figura 48 Viaduto São Paulo (Laurão) em 1976.

Figura 49 Viaduto São Paulo (Laurão) em 1984.

Figura 50 Loja McDonald's na Av. José de Sousa Campos (1986).

Figura 51 Ventura Mall na Av. Dr. Moraes Salles (1993).

Figura 52 Mapa dos acessos pela Av. José de Sousa Campos.

Figura 53 Imagem aérea região do viaduto São Paulo.

Figura 54 Fotos da região do córrego Proença.

Figura 55 Imóvel para locação após a aprovação da Lei n 10.566/00.

Figura 56 Demolição de imóveis na Av. José de Sousa Campos para a construção de torre comercial.

Figura 57 Prédio do Fórum Trabalhista da $15^{\mathrm{a}}$ Região.

Figura 58 Uso do solo na Nova Campinas após aprovação da Lei Complementar n 62/2014.

Figura 59 Levantamento de uso do solo da Nova Campinas em Fevereiro de 2015. 
Figura 60 Modelo de planilha utilizada no levantamento de uso do solo.

Figura 61 Gráfico de uso do solo em fevereiro de 2015.

Figura 62 Imóvel para locação com faixa anunciando o uso comercial (após a promulgação da Lei Complementar n62/2014).

Figura 63 Loja de Móveis na Av. Jesuíno Marcondes Machado.

Figura 64 Loja de móveis planejados na Av. Jesuíno Marcondes Machado.

Figura 65 Complexo de exames hospitalares, por imagem e laboratoriais, ocupando 4 imóveis na Av. Jesuíno Marcondes Machado.

Figura 66 Estacionamento do complexo na Av. Jesuíno Marcondes Machado.

Figura 67 Imóvel trabalhando de "portas fechadas" em rua sem permissão de usos terciários.

Figura 68 Imóvel trabalhando de "portas fechadas" em rua sem permissão de usos terciários.

Figura 69 Imóvel em reforma para receber uso comercial (Janeiro de 2015).

Figura 70 Dificuldades de mobilidade na Rua Viscondessa de Campinas.

\section{LISTA DE TABELAS:}

Tabela 1 - Loteamentos aprovados 1920-2010.

Tabela 2 - Dados estatísticos: Economia e Demografia.

Tabela 3 - Empresas por segmento econômico.

Tabela 4 - Habite-se imóveis Rua Carlos Stevenson. 


\section{SIGLAS E ABREVIATURAS:}

APA: Área de Proteção Ambiental. Se refere à MZ1-APA Macrozona 1, que, grosso modo, compreende o território dos Distritos de Sousas e Joaquim Egídio.

CIATEC: Companhia de Desenvolvimento do Polo de Alta Tecnologia de Campinas; CONDEPACC: Conselho de Defesa do Patrimônio Artístico e Cultural de Campinas;

CNAE: Cadastro Nacional de Atividade Econômica;

CSE e CSE-1 a CSE-6: Tipos de ocupação (conjunto de parâmetros construtivos) previstos na Lei 6.031/88 para edificações destinadas a abrigar atividades comerciais, de serviços e institucionais. Quando se tratar de edificações de uso misto as tipologias são HCSE e HCSE-1 a HCSE-5;

CSE-BG, CSE1-BG e CSE2-BG: Tipos de ocupação (conjunto de parâmetros construtivos) previstos na Lei 9.199/96 (Plano Local de Barão Geraldo) para edificações destinadas a abrigar atividades comerciais, de serviços e institucionais. Quando se tratar de edificações de uso misto as tipologias são HCSE-BG e HCSE1BG e HCSE2-BG;

CSPC: Coordenadoria Setorial do Patrimônio Cultural - Órgão técnico de apoio ao CONDEPACC;

EHIS: Empreendimento Habitacional de Interesse Social, conforme Lei $n^{\circ}$ 10.410/00;

LUOS: Lei de Uso e Ocupação do Solo de Campinas - Lei no 6.031/88;

PLG-BG: Lei n 9.199/96 - Plano Local de Gestão de Barão Geraldo. Abrange todo o território do Distrito (Macrozona 3) e cria parâmetros e Zoneamentos específicos (CSE-BG, Zona 3 BG, etc.);

MACROZONA: Subdivisão macroterritorial prevista no Plano Diretor (Lei Complementar $n^{\circ} 15 / 2006$ ) que estipula 9 Macrozonas no Município de Campinas. Em cada Macrozona deveria ser estabelecido um Plano Local de Gestão próprio; Estas Macrozonas são compostas por 34 APs (Áreas de Planejamento), subdivididas, por sua vez, em 77 UTBs (Unidades Territoriais Básicas);

NEPO: Núcleo de Estudos de População da UNICAMP, Universidade Estadual de Campinas;

PMC: Prefeitura Municipal de Campinas;

SBNC: Sociedade do Bairro Nova Campinas;

SMAJ: Secretaria Municipal de Assuntos Jurídicos;

SEPLAN: Secretaria de Planejamento e Desenvolvimento Urbano;

SEMURB: Secretaria Municipal de Urbanismo;

ZONA: área cujas características de uso e ocupação são definidas na lei de zoneamento, com o intuito teórico de se evitar incompatibilidade de usos e relacionar as densidades à capacidade de suporte da infraestrutura urbana. Em Campinas, a LUOS previa, inicialmente, a existência de 18 zonas. 


\section{SUMÁRIO:}

Índice de ilustrações $\quad$ fl. 08

Índice de tabelas $\quad$ fl. 10

$\begin{array}{ll}\text { Índice de Siglas e abreviaturas } & \text { fl. } 11\end{array}$

$\begin{array}{ll}\text { INTRODUCÃO } & \text { fl. } 13\end{array}$

CAP 1 - ZONEAMENTO: ORIGENS E REPERCUSSÕES NO TERRITÓRIO PAULISTA

1.1 - A Gênese do zoning system: $\quad$ fl.18

$\begin{array}{ll}1.2 \text { - A experiência alemã } & \text { fl.24 }\end{array}$

$\begin{array}{ll}\text { 1.3 - A Matriz Norte-americana } & \text { fl.35 }\end{array}$

1.4 - A influência no território paulista: $\quad$ fl.44

CAP 2 - A DINÂMICA DO SETOR TERCIÁRIO $\quad$ fl.50

CAP 3 - O ZONEAMENTO EM CAMPINAS

3.1 - Campinas, a Lei de Uso e Ocupação, e o setor terciário. fl.65

3.2 - Parâmetros e definições da LUOS $\quad$ fl.90

CAP 4 - O BAIRRO NOVA CAMPINAS

4.1 - A Nova Campinas $\quad$ fl.104

4.2 - O Ocaso residencial e a ascenção do terciário. fl.116

4.3 - Os Impasses entre a lei e a dinâmica urbana. fl.134

4.4- Levantamento de usos e conclusões. $\quad$ fl.150

5-CONSIDERACÕES FINAIS $\quad$ fl.158

6-REFERÊNCIAS

4.1 - Referências bibliográficas. $\quad$ fl.162

4.2 - Referências sítios eletrônicos. fl.165

7-ANEXOS

Anexo A - Ata de constituição da Sociedade do Bairro Nova Campinas. fl.167 Anexo B - Trechos da transcrição de audiência pública sobre o PL $\mathrm{n}^{0} 31 / 2000$.

Anexo C - Reportagens sobre as visões conflitantes a respeito dos usos terciários na Nova Campinas. 


\section{INTRODUÇÃO:}

Em Campinas, a base da legislação urbanística é o zoneamento como definido pela Lei Municipal $n^{\circ}$ 6.031/88, promulgada em 28 de dezembro de 1988 e que ainda está em vigência.

Há um consenso entre todos os meios técnicos, acadêmicos e políticos da cidade, quanto à necessidade de repensar a legislação de modo global. Este tema é recorrente, e não foram poucas as tentativas neste sentido, todas abortadas por algum motivo superveniente, devido principalmente às vicissitudes políticas de cada momento ${ }^{1}$.

O fato é, que apesar desta alteração conceitual nunca ter sido encaminhada de maneira sistemática, a legislação foi sendo alterada (às vezes pontualmente, e respondendo a interesses de grupos muito específicos) de maneira a, pelo menos, mitigar parcialmente os conflitos decorrentes de sua inadequação em lidar com as necessidades de uma sociedade em processo de constante e acelerada mudança.

A questão que se coloca é se, e como, uma legislação engendrada no final dos anos 80 e com um arcabouço teórico datado do início do Séc. XX pode dar conta das necessidades espaciais em uma sociedade pós-industrial e do modelo de produção pós-fordista, em constante mutação nestas quase três décadas em que a Lei, em que pesem suas inúmeras alterações, permanece com sua estrutura teórica engessada.

Qual a origem desta maneira de se tentar ordenar a cidade? Por que o termo Zoneamento se confunde com planejamento?

Em relação ao setor terciário ${ }^{2}$, especificamente, (setor sujeito a dinâmicas muito próprias de acordo com fatores macro e microeconômicos, e especialmente sensível à questão da localização no território), a defasagem das concepções que

\footnotetext{
${ }^{1}$ Atualmente está em curso mais uma destas tentativas, desta vez com o apoio técnico de uma consultoria da FUPAM, porém até o momento (2015), ainda não foi enviado à Câmara Municipal o Projeto de Lei da nova Lei se Uso e Ocupação do Solo.

${ }^{2}$ Setor Terciário: Segundo Vargas (2001, p.32), “[...] a origem do nome setor terciário é decorrência do seu posicionamento com relação à terra, onde a agricultura assume o primeiro lugar (primário). A transformação do produto da terra realizada pela indústria vem em segundo lugar (secundário), deixando para as demais atividades, o terceiro lugar (terciário).

Outro aspecto a destacar e a própria natureza da atividade terciária, que apresenta um alto grau de efemeridade e ausência de corporeidade, Isto é, ela encerra-se no momento do ato da troca e, portanto, é efêmera e não se materializa através de nenhum produto, É apenas um ato, e, portanto, não tem corpo."
} 
norteiam a legislação, exige uma investigação mais aprofundada a respeito da capacidade do modelo de zoneamento funcional restritivo dar conta das mais diversas demandas sociais, no sentido da sua espacialização no território.

Este modelo de zoneamento restritivo e de proteção ao uso residencial singular encontra dificuldades de toda ordem, ao ser transplantado tardiamente para as áreas já consolidadas de nossas cidades, onde encontra um território muito menos homogêneo.

A aplicação destes dispositivos depende da capacidade por parte do poder público e da vontade dos grupos de interesse em fazer com que sejam observados. Entre nós, este cenário praticamente só ocorre em bairros de alta renda, e mesmo assim, somente enquanto os interesses dos proprietários ainda seguem numa mesma direção, isto é, o interesse pelo valor de uso do imóvel, em contrapartida ao seu valor de troca.

O modelo da residência unifamiliar em um lote singular consolida-se no Brasil nas primeiras décadas do Séc. XX, se tornando hegemônico no desenho da cidade que se expande através da abertura de loteamentos, de forma a reproduzir os excedentes de capitais disponíveis.

$E$, imbricado à figura da residência unifamiliar, desenvolve-se este padrão de zoneamento monofuncional que resulta, segundo Choay (2005, p.45), em uma "morte parcial dos bairros", cuja ocupação só acontece em horas fixas.

Este tipo de expansão contribui sobremaneira para o fenômeno da dispersão urbana, que por sua vez, se agrava com a consolidação da matriz rodoviária nos transportes públicos e privados.

Em Campinas, esta morte parcial pode ser observada em diversos bairros residenciais onde predomina este padrão de ocupação monofuncional ${ }^{3}$.

Ao contrário dos novos loteamentos de alta renda (quase sempre fechados) e da profusão de condomínios residenciais horizontais ${ }^{4}$ onde fica sempre mais simples

\footnotetext{
${ }^{3}$ A maior parte do território de Campinas recebe na LUOS a definição de "estritamente residencial".

${ }^{4} \mathrm{O}$ modelo de condomínios residenciais horizontais, ganha força com o aumento da violência urbana ao ser vendido pelo mercado imobiliário como uma alternativa que fornece uma suposta sensação de segurança. Este modelo também apresenta maiores facilidades para o empreendedor em relação aos loteamentos convencionais, a partir das restrições impostas pela legislação federal (Lei 6.766/1979) que obriga o loteador a fornecer a infraestrutura e a doação de áreas mínimas institucionais e de lazer além do sistema viário, o que não ocorre nos condomínios que são regulados pela Lei federal 4.591/64.
} 
garantir as características monofuncionais previstas na legislação, alguns bairros tradicionais consolidados de alta renda já apresentavam um padrão de uso menos homogêneo, quando da promulgação da LUOS.

Entre estes bairros que já apresentavam uma ocupação com alguma diversidade, podemos citar bairros tradicionais como a Nova Campinas, o Parque Taquaral, o Jardim Guanabara, o Jardim Nossa Sra. Auxiliadora, o Jardim Flamboyant, Jardim Alto do Cambuí e a Cidade Universitária Campineira, entre outros.

Apesar de serem bairros que surgiram em diferentes momentos históricos ${ }^{5}$, em 1988 todos apresentavam porções de seu território onde outros usos, especialmente os do terciário, já haviam se instalado.

Devido ao terciário já existente, com fluxos maiores nas vias principais ou lindeiras, ou mesmo em vias que se conectavam com áreas mais adensadas e com usos mistos, estes bairros não foram zoneados integralmente como Z-3 no momento da promulgação da LUOS.

A LUOS está em vigor há quase 28 anos. Não foram poucas as mudanças culturais, econômicas, tecnológicas e sociais destas quase três décadas.

Quanto ao setor terciário, um enorme número de atividades, bens e serviços, surgiu e outros tantos desapareceram ou estão em vias de desaparecer.

Os avanços tecnológicos permitiram que serviços que antes demandavam grande concentração de funcionários e equipamentos, como agências bancárias (que costumavam se concentrar nas áreas mais centrais e mais adensadas, pois demandavam edificações de maior porte) possam ser oferecidos de maneira dispersa no território, inclusive ocupando imóveis residenciais adaptados.

Com a dispersão da população e as mudanças da direção e da intensidade de fluxos em constante evolução na cidade, há um processo natural de substituição do uso das edificações por atividades de comércio e serviços.

No caso do bairro Nova Campinas, que será nosso estudo de caso, há

\footnotetext{
${ }^{5}$ A Nova Campinas, o Jardim Guanabara e o Jardim N. S. Auxiliadora, por ex., têm sua origem nas décadas de 30 e 40 , enquanto a Cidade Universitária Campineira foi aprovada em 1968, mas somente viria a ser mais ocupada a partir de meados da década de 70
} 
claramente um aumento na disponibilidade de imóveis residenciais que se esvaziam a partir do início dos anos 90. São imóveis em geral muito bem construídos, adequados à instalação de escritórios ou clínicas, com localização quase central e facilidade de acesso, na região com maior infraestrutura da cidade.

Esta situação é decorrência também da modificação no padrão de expectativas quanto à habitação nas camadas de renda mais altas, a partir do final dos anos 80. Nesta ocasião, verificou-se uma explosão de condomínios e loteamentos fechados em Campinas (SILVA, 2008), além de novos lançamentos de edifícios multifamiliares residenciais, estes após a retomada dos financiamentos e o ciclo de desenvolvimento que se sucede à crise de 1998.

Algumas dessas áreas se tornaram desinteressantes como espaço de moradia com imóveis sendo paulatinamente ocupados por outros usos ligados ao terciário, especialmente pelo setor de serviços, numa velocidade que a legislação não acompanhou.

Enquanto na maior na parte do município, que tinha como característica zoneamentos "estritamente residenciais" (Z-2, Z-3, Z-4 e Z-6 a Z-8) os usos terciários foram acomodados de alguma maneira, através das leis de flexibilização, (cujo paradigma, como veremos no Cap. 3, foi a pioneira Lei $n^{\circ} 8.737 / 96$ ). Nestes bairros de alta renda "protegidos"6, o discurso da exclusividade permaneceu até bem pouco tempo, e quando aconteceram alterações, estas foram sempre muito tímidas, envolvendo apenas trechos de algumas vias e algumas poucas categorias de serviços e comerciais.

Este quadro somente viria a se modificar mais radicalmente em 2014, com a edição da Lei Complementar $n^{\circ}$ 62/2014, mas ainda aqui as alterações são no sentido reconhecer que alguns (na verdade, hoje a maioria) dos imóveis residenciais unifamiliares, hoje somente adquirem interesse econômico ao possibilitar outros usos.

A compreensão deste processo de inércia da legislação urbanística, frente à dinâmica urbana cada vez mais veloz, bem como a indicação dos equívocos

\footnotetext{
${ }^{6}$ A LUOS define uma listagem de 28 bairros de alta renda, das zonas 3 e 4, como "protegidos", ou seja, o comércio e os serviços ainda que de suporte local, estão completamente excluídos (proibidos), bem como as edificações multifamiliares verticais, conforme exposto na Alínea d) do Inciso III do Artigo 27, Lei n ${ }^{\circ}$ 6.031/88.
} 
relacionados à definição rígida dos parâmetros e dos usos do setor terciário presentes nessas legislações são os objetivos principais da presente dissertação, tendo como referência a cidade de Campinas.

Para tanto, o primeiro capítulo apresenta uma introdução às origens do zoneamento, suas primeiras formulações teóricas e aplicações práticas, inicialmente na Alemanha recém-unificada e depois sua adoção e disseminação, nos Estados Unidos (a partir do plano de Nova York, em 1916), onde o zoning adquire um caráter diverso do modelo alemão, muito mais focado na proteção aos valores imobiliários.

É esta concepção norte-americana do zoning que vai ser incorporada nas nossas legislações de uso e ocupação do solo.

O segundo capítulo traz algumas reflexões sobre a dinâmica do setor terciário e sobre as dificuldades de normatizá-lo de acordo com este modelo de legislação.

A partir destas discussões, o capítulo 3 apresenta a evolução da cidade de Campinas e o processo de adoção de suas legislações urbanísticas, suas intenções e dificuldades para então criar o contexto para a análise do bairro Nova Campinas, objeto desta Dissertação, a ser tratado no Capítulo 4.

Este capítulo, por sua vez, examina mais detidamente um bairro que já foi a mais importante área residencial de alta renda da cidade e suas transformações, com uma ocupação hoje predominantemente voltada ao setor de serviços, apesar de todas as restrições existentes na Lei de Uso e Ocupação do Solo de Campinas e da oposição de parte dos moradores.

Nas considerações finais, esperamos poder pontuar os principais aspectos que devem nortear as legislações de uso e ocupação do solo, quando se tratar de definições sobre o uso, ocupação e localização das atividades do setor terciário. 


\section{CAPÍTULO 1}

\section{ZONEAMENTO: ORIGENS E REPERCUSSÕES NO TERRITÓRIO PAULISTA}

\section{1 - A Gênese do zoning system:}

ZONEAMENTO URBANO: (urban zoning/zonage urbain/zonificiación urbana): Divisão das zonas urbana e de expansão urbana, delimitadas por lei, em zonas ou espaços especializados de usos e ocupação do solo, de forma predominante. [...] LEI DE ZONEAMENTO (zoning act/loi de zonage/ley de usos del suelo): Preceito legal, de natureza administrativa, que, em benefício do bem comum e de cada cidadão, regulamenta os usos e ocupação do solo urbano, estabelecendo para cada zona as normas e restrições urbanísticas. Consiste praticamente na divisão das zonas urbanas e de expansão urbana de um Município em zonas menores, claramente definidas e delimitadas (planta de zonificação), para as quais são prescritos: os tipos de uso do solo permitidos (residencial, comercial, industrial e institucional); as taxas, coeficientes ou índices de ocupação e de aproveitamento dos lotes pela construções; os recuos mínimos com relação às divisas do lote, gabaritos de altura das construções, áreas e medidas mínimas dos lotes, densidades demográficas e algumas outras normas urbanísticas. O mesmo que lei de usos e ocupação do solo urbano (FERRARI, 2004, p. 395 e 213).

A existência de normas que de alguma maneira procuram regular as edificações e seus usos, e especialmente, determinadas atividades consideradas de potencial nocivo nas cidades, não é uma invenção ou consequência da era industrial. Segundo Hirt (2014), o próprio Código de $\mathrm{Hamurabi}^{7}$ já trazia algumas disposições no sentido de garantir a estabilidade e segurança das edificações.

\footnotetext{
${ }^{7} \mathrm{O}$ código de Hamurabi é o considerado o conjunto integral de leis (282, em cerca de 3.600 linhas de escrita cuneiforme acadiana) mais antigo que chegou até nossos dias. Datado de cerca de 1700 A. C., regula praticamente todos os aspectos cotidianos da vida na Suméria (Mesopotâmia) de então. A estela de pedra com as inscrições foi encontrada próximo a Susa Irã, por uma expedição francesa em 1901 e hoje está exposto no Museu do Louvre. Fontes: Wikipedia: https://pt.wikipedia.org/wiki/C\%C3\%B3digo de Hamurabi e dhnet.org: www.dhnet.org.br/direitos/anthist/hamurabi.htm
} 
A autora afirma que regulamentos edilícios estiveram presentes em diversas culturas desde as civilizações do Indo (Harappa, Mohenjo-Daro) e antigo Egito, passando pela China, Grécia (Porto de Pireu, cujo plano de autoria de Hippodamus, foi citado tanto por Platão como por Aristóteles, que considerava o autor como "inventor da arte de planejar cidades") e num nível acima, Roma, cujos princípios de planejamento foram compilados através da obra de Vitruvius.

Para além das regras quanto às estruturas de defesa, e as destinadas a definir posição de templos e edifícios públicos ou localização dos mercados, havia as questões de divisão de castas, religião ou etnia.

Outra preocupação que perpassa todos estes momentos históricos é a segregação de atividades consideradas indesejáveis por resultarem em insalubridade, odores, ou riscos de incêndio (tais como curtimento de couros, matadouros, forjas e produção de tijolos). Após o grande incêndio de 1666, Londres estipulou novas regras mais rígidas quanto aos materiais, além de vedar vielas estreitas com edificações muito próximas.

A autora argumenta que mesmo onde havia claramente disposições identificando áreas residenciais, isto jamais assumiu o caráter excludente do zoning moderno, até mesmo por que as atividades comerciais e de manufatura sempre estiveram intimamente ligadas à moradia dos que as exerciam.

O advento da renascença e do barroco, bem como a obsolescência das muralhas diante do desenvolvimento da artilharia, trazem novas preocupações estéticas quanto ao desenho das cidades.

Os grandes espaços públicos passam a ser mais bem definidos, e alguns enclaves de moradias de extratos sociais mais altos podem ser notados, porém sempre coexistindo ao lado de bolsões de habitações da classe trabalhadora.

A utilização do andar térreo para o exercício de atividades profissionais ou comerciais não era exclusiva somente da classe trabalhadora: A atividade de banqueiro, por exemplo, era exercida na própria residência. Em Londres, o primeiro edifício de uso especializado, o do Banco da Inglaterra, somente aparece em 1734. (ABRANSON, apud HIRT, 2014) ${ }^{8}$.

\footnotetext{
${ }^{8}$ Abranson, D. Money's Architecture: The building of Bank of England, 1731-1833. Ph. D. Dissertation, Harvard University.
} 
O advento da revolução industrial modifica completamente a vida urbana nas grandes cidades europeias. Os contingentes populacionais de trabalhadores se aglomeravam em condições insalubres em cortiços e porões. A descrição do pesadelo em que se tornaram as grandes aglomerações urbanas da era industrial permanece vívida no clássico publicado em 1845, "A Situação da classe trabalhadora na Inglaterra" de Friedrich Engels.

O século XIX assistiu ao aumento da especialização funcional nas cidades, seja em termos de distritos que aglomeram atividades similares e/ou complementares ${ }^{9}$, ou em relação aos edifícios que assumem um caráter altamente especializado e monofuncional (bancos, escritórios, lojas de departamentos).

Ao mesmo tempo em que esta especialização de funções das edificações avançava, as áreas de moradia se apartavam cada vez mais do restante da cidade.

Conforme aponta Hirt (2014), a separação entre moradia e trabalho é uma característica da sociedade industrial.

Os engenheiros municipais das primeiras décadas do Séc. XIX se depararam com uma transformação inédita na história da cidade por sua velocidade, intensidade e escala. Segundo Choay (2005), Londres passa de 864.845 habitantes em 1801 para 1.873 .676 em 1841 e 4.232 .118 em 1891. O número de cidades inglesas com mais de 100.000 habitantes passa de duas para trinta, de duas para vinte e oito na Alemanha e de três para doze na França. Em 1800 não há nenhuma cidade com mais de 100.000 habitantes nos Estados Unidos, mas em 1850 são seis e em 1890 chegam a vinte e oito.

A urbanização decorrente da industrialização e seus fenômenos mais visíveis, a especulação imobiliária e a deterioração do ambiente urbano, ensejaram a adoção de regulamentos de controle dos volumes e da distribuição dos usos produtivos, como a proibição de determinadas atividades em áreas específicas das cidades.

\footnotetext{
${ }^{9}$ As condicionantes logísticas da produção e consumo em massa na era industrial logo tornaram vantajoso que negócios similares localizassem suas atividades e edifícios próximos uns aos outros. Segundo Hirt $(2014$, p.103) isto permitiria um melhor aproveitamento das cadeias de suprimentos e transportes e a competição pelos mesmos consumidores. A concentração de determinados ramos de comércio nas chamadas ruas especializadas também se inserem neste contexto, com ganhos de escala superando as adversidades de uma possível concorrência predatória.
} 
Em 1810, Napoleão Bonaparte emitiu um Decreto Imperial (Reynard, 2002 ${ }^{10}$ apud HIRT, 2014 p.105) criando distritos protegidos nas cidades do império, exigindo que indústrias poluidoras obtivessem permissão do estado para se instalarem nestas áreas. Enquanto algumas cidades alemãs já exerciam estas restrições, na esteira das disposições Napoleônicas o governo prussiano logo emitiu legislação com alcance nacional esta direção.

$\mathrm{Na}$ Grã-Bretanha, em 1844 a cidade de Londres emite o "Metropolitan Building $A c t^{\text {"11 }}$ que supera a simples divisão entre indústrias nocivas e as atividades restantes, ao instituir uma classificação das edificações de acordo com seus usos, que seriam divididos em três classes: $1^{\text {a }}$ (habitacionais), $2^{\text {a }}$ (atividades comerciais e industriais, como lojas, cervejarias, manufaturas ou mesmo estábulos), $3^{\text {a }}$ (edifícios público ou de caráter público: igrejas, teatros, universidades, escolas, hospitais e edifícios governamentais). O Ato não estipulava locais específicos para cada categoria, mas aqui estão as sementes das categorias modernas do zoneamento: residencial, industrial, comercial e cívico (institucional).

Segundo Hirt (2014), este modelo de legislação não tinha o caráter de separação de funções que viriam a caracterizar o zoning norte-americano no Séc. $\mathrm{XX}$, pois atividades comerciais e industriais estavam relacionadas em uma mesma categoria e somente se segregavam as atividades com alto potencial nocivo (poluição ou risco de causar incêndios).

Os urbanistas alemães da última metade do Séc. XIX, aprendendo com os erros e acertos de seus antecessores, acabaram por radicalizar o princípio do controle dos solos, sistematizando-o e organizando uma estrutura teórica e metodológica geral em que são incorporadas questões de eficiência produtiva, alocação de recursos (dentro de um projeto de desenvolvimento estruturado, numa nação recém-unificada) e também questões de ordem socioeconômica, como a manutenção dos valores da terra e uma tentativa de controlar as tensões políticas oriunda do choque dos diversos grupos sociais que habitam a cidade. (Mancuso, 1980).

\footnotetext{
${ }^{10}$ REYNARD, P. Public order and privilege: eighteenth-century french roots of enviromental regulation. Technology and culture 43, $\mathrm{n}^{\circ} 1: 1-28$.

${ }^{11} \mathrm{O}$ texto integral do Ato está disponível em: https://archive.org/details/metropolitanbui00britgoog
} 
De sua origem na Alemanha, o zoning se espalha rapidamente pelo mundo e especialmente nos Estados Unidos, onde questões da preservação do valor da terra e de seu rendimento assumem a preponderância (nem sempre de modo explícito) na conformação da legislação urbanística.

Ao acessarmos a página web do Departamento de Planejamento de Nova lorque (New York City Planning), nos deparamos com a seguinte afirmação a respeito do zoning: "O zoning molda a cidade" (Zoning shapes the city, no original) ${ }^{12}$.

Este "fetiche" pelo zoneamento como principal instrumento de planejamento urbano criou profundas raízes na tradição americana de "urban planning", se espalhando pela maior parte das cidades norte-americanas, de todos os portes. (TOLL, 1969).

No início da década de 1920, em Euclid, cidade da região metropolitana de Cleveland - Ohio, uma empresa de "real state" a Ambler Realty, pretendia desenvolver um empreendimento industrial em uma vizinhança onde o plano feito em 1922 pelo comitê de Zoneamento (Zoning Board) da cidade havia estipulado o uso residencial, o que inviabilizava as pretensões da empresa. Esta conseguiu uma vitória nos tribunais estaduais, alegando que se tratava de intromissão indevida no seu direito de propriedade.

Em 1926, julgando um recurso da municipalidade de Euclid, a Suprema corte reforma a decisão e declara que a adoção do zoning era "uma extensão razoável dos poderes de polícia da municipalidade" e que poderia se sobrepor à expectativa de lucro com um empreendimento, não se equivalendo, portanto, ao direito à propriedade $^{13}$. Esta decisão é o grande marco jurídico da disseminação do zoning por todo o país (TOLL, 1969, p.213; WOLF, 2008) ${ }^{14}$. Sua importância é de tal ordem que na literatura norte-americana sobre planejamento, o modelo de zoneamento restritivo, segregador de usos, recebe o nome de "Euclidean Zoning".

Segundo Toll (1969), em fins de 1916, ano em que New York adotou o zoning,

\footnotetext{
${ }^{12}$ Sítio do NYCity Department of City Planning: http://www.nyc.gov/html/dcp/html/zone/zonehis.shtml

${ }^{13}$ Village of Euclid, Ohio v. Ambler Realty Co. - https://supreme.justia.com/cases/federal/us/272/365/case.html

${ }^{14} \mathrm{O}$ caso Euclid x Ambler é apontado pela maioria dos autores que escrevem sobre a história do planejamento como o grande marco da consolidação do zoning nos Estados Unidos, tanto por defensores como por detratores do modelo. Para uma melhor compreensão de seu contexto e a amplitude de suas consequências na urbanização dos Estados Unidos, ver The Zoning of America: Wolf, Michael A. The Zoning of America: Euclid x Ambler. Lawrence, Kansas: 2008.
} 
havia 8 cidades com legislações semelhantes. Ao final dos anos 20, cerca de 800 localidades já utilizavam planos semelhantes. (TOLL, 1969 p.193).

E em 1936, vinte anos após o pioneirismo de New York, o total somava 1.322 localidades. Das 86 cidades americanas, então com mais de 100.000 habitantes, somente 14 ainda não tinham plano de zoneamento. (MANCUSO, 1980 p.171). Atualmente, entre as grandes cidades dos Estados Unidos, somente Houston (Texas), não possui um plano de zoneamento.

O Professor, Arquiteto e Urbanista Italiano Franco Mancuso (1980), em sua obra seminal sobre a questão do zoning se indaga o porquê das atividades deverem ser reagrupadas em áreas específicas (zonas) ao contrário das cidades antigas, onde estas atividades estão misturadas, atuando umas sobre as outras e produzindo um ambiente mais estimulante e um espaço mais visível.

Segundo o autor, os manuais modernos de urbanismo dizem que assim zonificada, a cidade será mais funcional, mais ordenada, com cada coisa em seu devido lugar, utilizando-se de um verniz de neutralidade científica ao embasar-se em cálculos demográficos muito precisos (tantos habitantes para tanto de transporte, tanto de escolas e de postos de trabalho, etc.) e que estudos sociológicos podem definir a quantidade de área verde ou de serviços demandada por uma determinada população.

Mancuso (1980, p.16) demole este entendimento que atribui ao zoning, um caráter de instrumento essencialmente técnico:

“[...] em su origem, el zoning es um fundamental instrumento ideológico, marcadamente funcional para la consecucción de objetivos económicos y sociales (...) estrechamente ligado al contexto ideológico, político e econômico - donde se origina; no es neutral, ni mucho menos los fenômenos considerados como negativos, que derivam de su aplicación - la segregación de los grupos sociales y el apoio a la renta, la esquematización de la ciudad y la rigidez de las prescripiciones - no son, de hecho consecuencias accidentales, em tanto coinciden com los objetivos mismos que el zoning assume desde um primer momento como prioritários. 


\section{2 - A Experiência alemã:}

A Alemanha, somente foi unificada em 1871 sob a dinastia prussiana dos Hohenzollern (BURNS, 1998) que a partir de então busca freneticamente acelerar seu desenvolvimento de modo a se equiparar às outras potências europeias.

A industrialização e o desenvolvimento econômico eram estimulados pelo estado e, encontrando condições adequadas como matérias-primas e mão-de-obra qualificada em abundância, em pouco tempo o grau de industrialização alemão equiparava-se (e até sobrepujava em vários setores) ao do Reino Unido e ao da França, principais forças econômicas europeias (a produção de aço e ferro dobrou no período 1880-90, dobrou novamente entre 1890 e 1900 e superou a do Reino Unido já na primeira década do Séc. $X X)$.

O crescimento das cidades alemãs foi exponencialmente acelerado no período, o que apresentou novas dificuldades às administrações municipais ${ }^{15}$.

Os conflitos entre os diversos agentes econômicos e sociais advindos dessa veloz transformação não podem ser, de modo algum, desprezados.

Mancuso (1980) explica que estes conflitos no campo econômico se dão em dois níveis: primeiro, entre os proprietários do solo urbano e todos os empresários industriais, comerciais e imobiliários; num segundo nível todos estes agentes se contrapõem, em relação às necessidades específicas dos diversos setores em que operam.

No primeiro caso o que existe é o conflito da renda da terra, enquanto mercadoria, em contraposição à terra como instrumento obrigatório de suporte à todas as outras atividades econômicas e produtivas, como o comércio, a indústria e a produção da habitação. Em suma, os interesses de quem faz uso da terra para produzir renda diretamente (grandes proprietários), em contraposição a todas as outras atividades produtivas.

No segundo, temos a competição entre os diversos segmentos que precisam da terra como suporte a sua atividade, em busca de uma localização que

\footnotetext{
${ }^{15}$ Dresden, por exemplo, passa de 90.000 hab em 1850 para mais de 400.000 hab em 1900 e mesmo em cidades menores como Bochum (passa no mesmo período de 4.000 para 65.000hab) e Dortmund (de 7.500 para 140.000hab), o fenômeno se multiplica. (MANCUSO, 1980).
} 
potencializem a sua atividade específica e diminua os custos incidentes.

Os altos custos dos terrenos urbanos começaram a se tornar um sério entrave, por exemplo, ao modelo alemão de grandes complexos industriais e a necessidade de mediação do poder público se torna então primordial para um país que perseguia o objetivo de desenvolvimento industrial acelerado.

Em relação a este problema específico, o advento da zonificação possibilita que se reservem grandes espaços localizados na periferia das cidades, para a instalação das indústrias, de maneira a beneficiar o investimento industrial, protegendo-o da valorização acelerada das áreas centrais ${ }^{16}$.

Por outro lado, no caso da habitação há um conflito que se se desenvolve entre os interesses das diversas classes sociais. Enquanto as classes abastadas tentam garantir a exclusividade do lote unifamiliar, sendo copiadas pelas classes médias emergentes (funcionários qualificados, burocratas, etc.), os enormes contingentes populacionais de trabalhadores para as indústrias acabam por se amontoar em condições de densidade insuportáveis e ameaçando as áreas de moradia da burguesia.

Estas áreas de alta densidade e péssimas condições de vida são um propício meio de cultura para a propagação dos ideais socialistas. Na Alemanha do último quarto do Séc. XIX há uma proliferação de construções de blocos de aluguel com altíssimas densidades e precárias condições sanitárias, num modelo de cortiço conhecido como "mietkasernen", ou seja, caserna de aluguel, numa referência aos quartéis militares ${ }^{17}$.

A questão que se apresenta como inadiável é como organizar esta cidade que precisa crescer e absorver toda a população necessária às fábricas e ao mesmo tempo garantir a produção e a propriedade privada do solo.

A solução: dividir a cidade em diferentes zonas e adotar em cada uma delas diferentes regras de edificação e de uso do solo. O zoning se torna a ferramenta de intervenção e mediação destes conflitos, porém intervindo sobre situações já

\footnotetext{
${ }^{16}$ Este tipo de solução encontra eco em muitos planos diretores atuais, com os famosos "distritos industriais" que são comuns até nos planos de cidades de pequeno porte, muitas vezes ocupando áreas muito superiores ao necessário para as dinâmicas econômicas locais.

${ }^{17} \mathrm{http} / /$ www.vitruvius.com.br/revistas/read/arquitextos/09.097/136
} 
estabelecidas, muito mais do que sobre as causas estruturantes destes conflitos.

A velocidade da urbanização da Alemanha pós-unificação, como já comentamos, traz enormes tensões e novos problemas a toda a sociedade.

Começa-se a esboçar uma consciência coletiva da necessidade de intervenção na cidade, em seu ambiente físico e social, ainda mais que se pôde observar os efeitos da urbanização em outros países que passaram pelo mesmo processo e há uma sensibilidade política e cultural, com vários autores discutindo estas questões já na década de 1870.

Em 1876 Reinhard Baumeister, professor da Universidade de Karlsrühe, publica "As ampliações urbanas em seus aspectos técnicos, normativos e econômicos"18. De acordo com Hirt (2014, p.135), os especialistas em história do zoning do início do Séc. XX classificam este como o trabalho pioneiro na ideia de dividir a cidade em distritos e estabelecer a cada um deles os tipos de edificação e de atividades permitidos.

Segundo aquela autora, uma das mais importantes observações do trabalho de Baumeister é a constatação de que as atividades econômicas na cidade industrial tendem a se concentrar em determinadas áreas e por isto propõe um mecanismo legal para reforçar esta tendência.

O município de Frankfurt $^{19}$ adota em 1891 um plano de zoneamento que abrange todo seu território, dividindo a cidade em zonas concêntricas e designando a cada uma delas, normas que definem densidade de edificação (mediante parâmetros de altura e taxa de ocupação) e a sua destinação de uso, dividindo o território em áreas residenciais, industriais e para usos mistos.

\footnotetext{
${ }^{18}$ Baumeister é citado por diversos autores, especialmente os americanos que foram no início do Séc. XX buscar conhecer a experiência alemã, visando sua aplicação nos Estados Unidos, como sendo o precursor teórico do zoning system (HIRT, 2014; TALEN, 2012; TOLL,1969;).

${ }^{19}$ Segundo Mancuso (1980) o primeiro documento onde aparece a aplicação do zoning é: "Polizeiverordnung vom 13 Oktober 1891, das Bauen in der Aussenstadt Frankfurt Am Main" - Norma da polícia de 13 de outubro de 1891 sobre as construções na cidade exterior em Frankfurt. Este documento usa o termo Zone System, e seus instrumentos de aplicação são o "bauzonenplan" (mapa que define as zonas) e a normativa de construção correspondente ou "zonenbauordnung".
} 


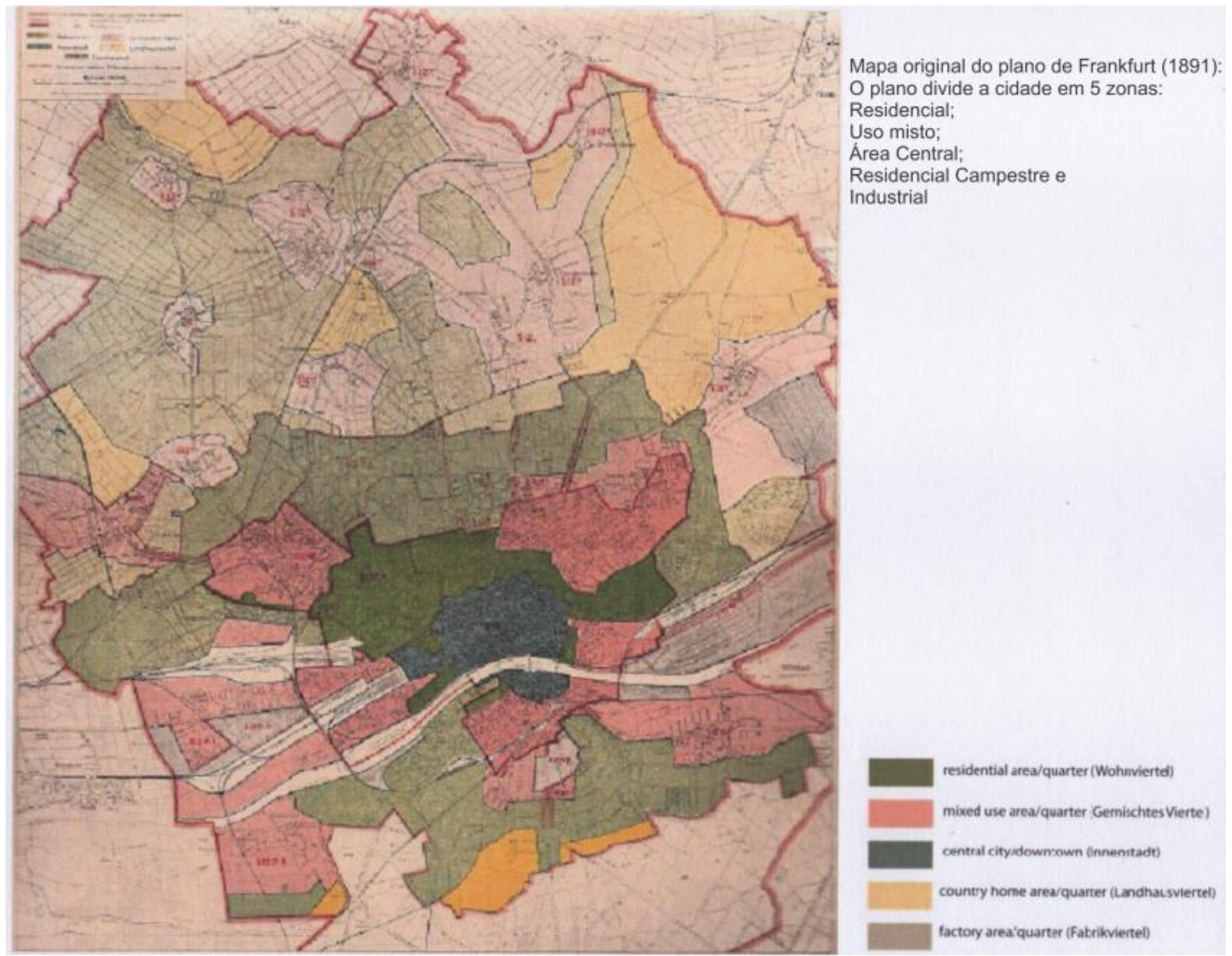

Fig. 1: Mapa do Zoneamento de Frankfurt de 1891. Fonte: a partir de Talen (2012a).

De acordo com Franz Adickes ${ }^{20}$, prefeito de Frankfurt, a zonificação por usos significa:

[...] "uma adequada classificação dos novos bairros urbanos em distritos residenciais, industriais e mistos, definindo sua distribuição e possibilidade de desenvolvimento em relação às distintas necessidades de edificação correspondentes aos distintos usos e funções (das casas maiores às menores, das grandes fábricas às pequenas oficinas industriais)”. (MANCUSO, 1980 p. 83) ${ }^{21}$

De acordo com sua visão, a cidade pode assim se desenvolver de modo mais ordenado, com as pessoas encontrando onde habitar conforme suas possibilidades de renda, as fábricas poderão se expandir, os portos se desenvolver, e até a

\footnotetext{
${ }^{20}$ O Dr. Franz Adickes assume como prefeito (Bürgermeister) de Frankfurt em 1891, cargo que ocuparia até 1912. Segundo Mancuso, Adickes é reconhecido como "O Urbanista" pela historiografia alemã, devido a sua extensa produção teórica e suas práticas reformadoras, com preocupações sociais bastante avançadas para a sociedade marcadamente conservadora do império alemão.

21 Tradução nossa.
} 
iniciativa privada após o choque inicial irá apoiar a regulação, dadas as vantagens dela oriunda e de quebra ainda se responde às demandas sociais, afastando o perigo da pregação socialista.

Era preciso incorporar a massa proletária dentro do esforço de construção do Império Alemão, sem incorrer em riscos de ruptura. Neste sentido, nada melhor do que a intervenção esclarecida de técnicos de formação cultural qualificada com visão progressista, muitos ligados à "Verein Fur Sozialpolitik" (União para a política Social) de corte liberal e socialdemocrata ${ }^{22}$.

Os principais instrumentos defendidos por Adickes, que vinha pondo-os em prática durante sua gestão em Frankfurt são:

1. A "zonenbauordnung", ou seja, o controle da exploração do uso do solo edificável mediante normas específicas através do sistema de zoneamento;

2. A apropriação, pela municipalidade da maior quantidade de solo possível, através da compra, sendo inviável a simples expropriação de todo o solo municipal;

3. A aplicação de normas legais sobre o parcelamento do solo, prevendo a expropriação pela municipalidade dos terrenos necessários para as necessidades públicas (parques, ruas, praças, ferrovias, etc.);

4. E, finalmente, a revisão do sistema de tributação dos solos.

Adickes procura tranquilizar os empresários e proprietários apresentado essas medidas como corretivas das distorções, de modo a controlar as ações especulativas e a garantir um ambiente empresarial e de investimentos saudável e próspero.

Assim, as propostas urbanísticas alemãs conseguem atingir o apoio de todos os agentes sociais. Ao mesmo tempo em que propõem medidas de controle e intervenção sobre o território, os urbanistas alemães como executores destas medidas intervém diretamente em operações que reestruturam completamente as grandes cidades alemãs.

\footnotetext{
22 “Verein Fur Sozialpolitik” é uma sociedade existente até hoje, fundada em 1873 como um encontro de jornalistas, economistas, cientistas sociais, ativistas políticos e homens de negócio e tinha como objetivo antagonizar os extremismos, tanto do laissez-faire, como das ideias socialistas revolucionárias, dentro de uma concepção de corte social-democrata. Como objetivo de então, propunham educar as classes proletárias, reconciliando-as com a ordem existente de modo a integrá-las no organismo social de modo pacífico e ordeiro. Fonte: sítio da Associação: https://socialpolitik.de/en/history
} 
Atinge-se um nível de reformas que melhora as condições de vida da classe trabalhadora, ainda que a ação sobre a construção de moradias populares pelo poder público seja limitada até pelo menos o fim da $1^{\text {a }}$ Guerra e, ao mesmo tempo, maximizam-se as capacidades produtivas da cidade.

Os sucessos do sistema alemão atraem a atenção nos Estados Unidos: há um importante fluxo de pesquisadores norte-americanos que, na primeira década de 1900 buscam conhecer os resultados da experiência alemã, ainda que muito mais atraídos pelo viés econômico do que pelo social (HIRT, 2014; TOLL, 1969).

O controle de densidades permite manejar adequadamente a distribuição de habitação, adequando-as à infraestrutura de transportes que se formava então e mesclando-se a áreas verdes e equipamentos públicos, resultando em condições melhores de salubridade, além do ganho no valor estético urbano.

O aumento na qualidade de vida, com melhor mobilidade, parques, museus, melhor infraestrutura urbana (portos e ferrovias são construídos pelas cidades como forma de atrais empresas), terrenos mais baratos para as indústrias, e moradia em melhores condições para as classes trabalhadoras resultam em uma cidade mais humana e ao mesmo tempo mais próspera. Deste modo, podemos dizer que o instrumento do zoning na sua vertente alemã, aparece como resposta tanto do ponto de vista econômico-social como do ponto de vista funcional (FELDMAN, 1997; TALEN, 2012a; TALEN, 2012b; TOLL, 1969).

A utilização da ferramenta do zoning (os trabalhos de Baumeister, especialmente) como base teórica para o que se convencionou de chamar de urbanismo funcional cria as condições para o posterior desenvolvimento do urbanismo modernista, com a separação de funções dividindo o território em áreas industriais, comerciais e residenciais:

Para as indústrias e o grande comércio se trata de diminuir os custos e maximizar os benefícios decorrentes da necessidade de espaço e de sua relação com o transporte e com as infraestruturas (o setor terciário, seguindo a mesma lógica, busca a localização como fator-chave, de modo a facilitar o fluxo e o contato das pessoas, maximizando a oportunidade das trocas, porém, como veremos mais adiante, quase nunca esta separação de usos dá conta das múltiplas facetas do terciário e de suas necessidades específicas). 
Já para as residências os critérios são tanto mais soltos, com exceção das moradias das classes mais abastadas, onde se busca densidades mínimas, de preferência com vistas, e abundância de verde ao redor. Em relação às moradias da classe trabalhadora, somente se ataca os excessos de densidade dos blocos de aluguel, limitando-se $o n^{\circ}$ de pavimentos de acordo com a zona. Com o tempo, procura-se alocar as densidades de acordo com a infraestrutura de transporte existente ou prevista.

Outro interessante aspecto da obra de Baumeister é seu posicionamento quanto à questão da segregação sócio-espacial entre diferentes classes sociais. Segundo ele existem duas tendências antagônicas, que advogam ou o completo apartamento ou o contato total. Para ele, contudo, deve-se encontrar um termo médio, pois do ponto de vista funcional não é possível que haja uma separação total entre pobres e ricos: "Lo cierto es que ni un gran número de pobres, ni un gran número de ricos puedem vivir aislados. Em efecto, existem ciertas necessidades que ligan una classe a otra, y hacen que sua separación este llena de problemas" (BAUMEISTER, $1876^{23}$ apud MANCUSO, 1980). Aqui, ainda são as questões relativas à eficiência econômica da cidade como máquina produtiva, que balizam a questão.

Nesta fase inicial os planos costumam ser muito sucintos e esquemáticos: em relação à densidade variam entre três e cinco zonas na maioria dos casos, sendo a densidade controlada pelo número de pavimentos permitidos, que varia de dois a cinco, em franjas concêntricas com maior densidade nas áreas centrais e menores nas periféricas.

Quanto aos usos divide-se geralmente a cidade em bairros mistos, bairros residenciais e bairros industriais, nos quais a habitação só é permitida para os casos de trabalhadores e proprietários das indústrias. Este é de grosso modo, o modelo que vai perdurar até meados da primeira década do Séc. XX.

A simplicidade esquemática destes planos iniciais acarreta problemas como a escassa articulação entre as diferentes zonas e o tamanho das zonas de uso singular. Além disto, o esquema de franjas concêntricas acaba por segregar a população de menor renda para as áreas periféricas, pois é onde se encontram os

${ }^{23}$ BAUMEISTER, Reinhardt. "As ampliações urbanas em seus aspectos técnicos, normativos e econômicos". 
terrenos de preço mais acessível.

A partir da primeira década do Séc. $X X$ começam a se delinear planos mais complexos, levando em conta, por exemplo, não apenas o número de pavimentos, mas também determinadas tipologias, especialmente no que tange às áreas residenciais, diferenciando os apartamentos operários de blocos de aluguel, os apartamentos "senhoriais" e as casas burguesas unifamiliares ou geminadas, sempre de acordo com as classes a que se destinam. Para isto fazem relações entre a largura da rua e a altura das edificações, bem como a necessidade ou não de espaços ajardinados.

Outra inovação que aparece neste momento é a atribuição de determinados usos específicos a ruas ou agrupamentos de ruas num fracionamento que procura dar conta da complexidade da vida urbana moderna e de maneira a permitir a coexistência de usos diversificados situados relativamente próximos, numa maior integração das diferentes atividades. A rua passa a ser a unidade de delimitação da zona.

Os êxitos atraíram a atenção de urbanistas e advogados norte-americanos, que vão buscar na Alemanha subsídios para aplicar nos Estados Unidos, o que Hirt (2014, p.134) classifica como "A Invenção Alemã", isto é, a ideia de que as cidades devam ser divididas em distritos, onde se aplicam diferentes regras de uso e ocupação do solo.

Na América o zoning adquire um caráter diverso, muito mais focado na questão da proteção aos valores das propriedades. Por isto há uma ênfase muito maior na separação de usos, especialmente nas áreas destinadas às habitações unifamiliares. Enquanto que na Europa vários tipos de pequenos negócios e atividades terciárias de suporte, são permitidas em áreas residenciais, no modelo norte-americano, a exclusão total é a regra mais comum (TALEN, 2012b; HIRT, 2014).

Williams (1922 p.215) nota que no ordenamento de Frankfurt, por exemplo, não há a exclusão de negócios nas áreas residenciais. Para o autor, a tendência de segregar negócios e habitação tão forte nos Estados Unidos, não encontra paralelo na maior parte da Europa. Este autor aponta que não há um único quarteirão em Berlin onde lojas e escritórios estejam completamente proibidos, e pouquíssimos em 
Paris e Viena.

Segundo Hirt (2014, p.158-9) apesar de o zoning compreensivo (isto é, em todo o território da cidade) ser uma invenção alemã, foram os americanos que, progressivamente desenvolveram a ideia de separação total entre habitação e trabalho.

Talen (2012a) afirma que a partir das gestões de Herbert Hoover como Secretário de Comércio e depois durante sua Presidência, foram estabelecidas legislações promovendo os códigos de zoneamento (zoning ordinances) e, em especial, a criação dos distritos exclusivamente residenciais singulares.

Ao compararmos a concepção alemã acerca da ferramenta do zoneamento à norte-americana, podemos observar que há um desvio da ideia original do conceito de zoning. $\mathrm{Na}$ Alemanha, o Zoneamento persegue uma lógica espacial da maximização da eficiência produtiva e da qualidade do espaço urbano, procurando mitigar os efeitos indesejáveis da rápida industrialização do país após 1871 .

Segundo Talen (2012b), o zoning como proposto pelos planejadores alemães aparece como uma forma codificar um arranjo espacial determinado pelas linhas de transporte onde toda uma gradação se estabelecia. Próximo aos parques, áreas abertas e equipamentos esportivos, uma fileira de residências unifamiliares, circundados por pequenos edifícios multifamiliares de médio porte que por sua vez estão adjacentes (mas protegidos) de prédios comerciais e lojas em ruas comerciais de maneira a garantir a todos um bom acesso para suprir as necessidades do dia-adia.

Outro ponto que Talen (2012b) aponta como diferenciação entre o modelo alemão e o americano, é que no primeiro, a proposição de baixas densidades se destina a manter baixo o preço solo para as classes trabalhadoras, enquanto que no segundo essas mesmas baixas densidades servem para garantir a exclusão de contingentes indesejáveis das áreas mais valorizadas, ao estimular a figura da residência unifamiliar em lotes com áreas mínimas elevadas.

Para Feldman (1997, p.9), o zoning, em sua concepção alemã atua tanto do ponto de vista técnico/estrutural como no campo compositivo/formal, sempre acoplado a políticas sociais, inclusive preocupando-se com a habitação social, como no caso das "siedlugen" - conjuntos habitacionais destinados à classe operária e 
patrocinados pela municipalidade, que se disseminarão após 1919, dentro do esforço de reconstrução pós I Guerra, sendo que algumas contam inclusive com projeto de arquitetos renomados como Bruno Taut, Martin Wagner e, especialmente, Ernst May, com vários projetos executados em Frankfurt.
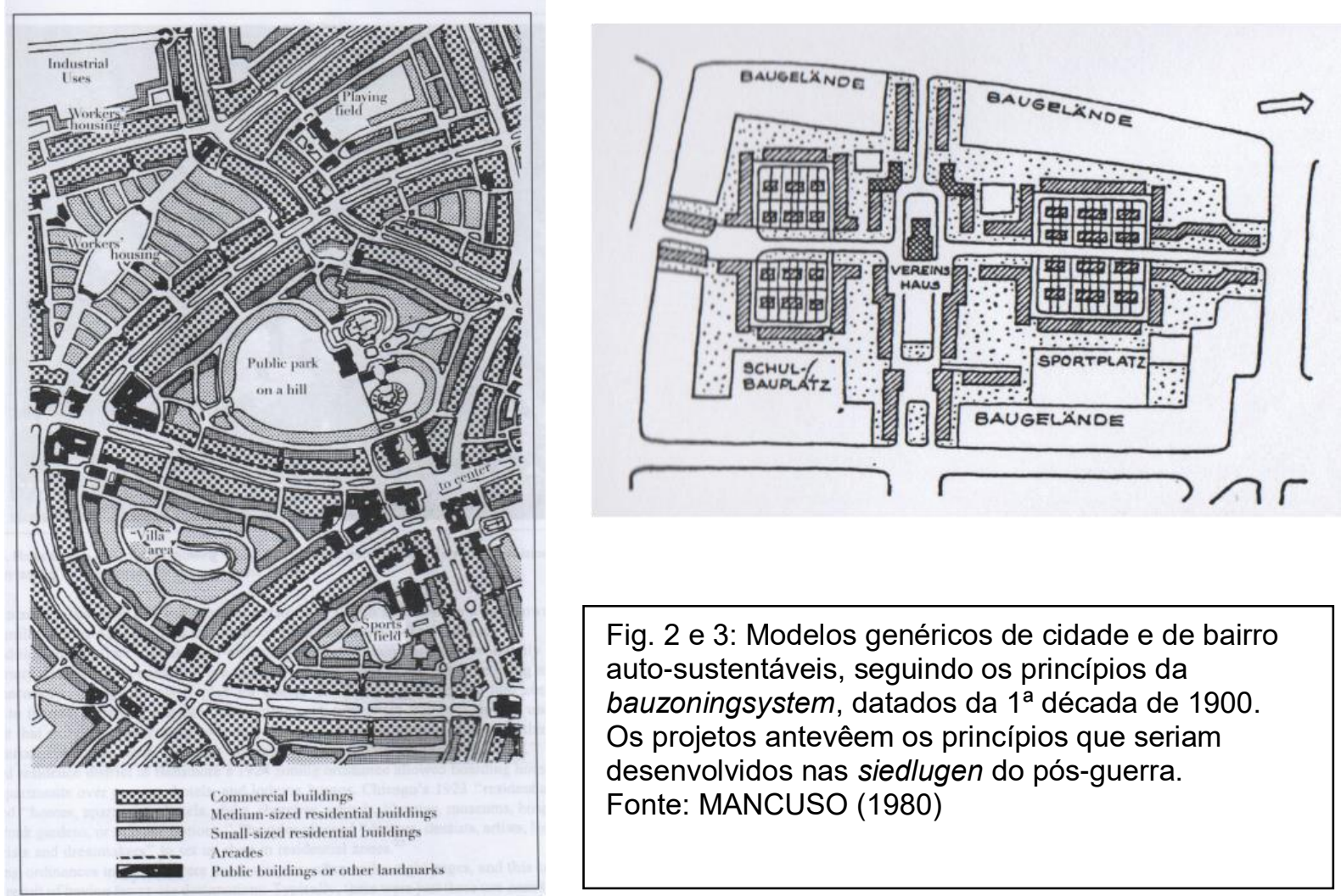

Fig. 2 e 3: Modelos genéricos de cidade e de bairro auto-sustentáveis, seguindo os princípios da bauzoningsystem, datados da $1^{\text {a }}$ década de 1900. Os projetos antevêem os princípios que seriam desenvolvidos nas siedlugen do pós-guerra. Fonte: MANCUSO (1980)
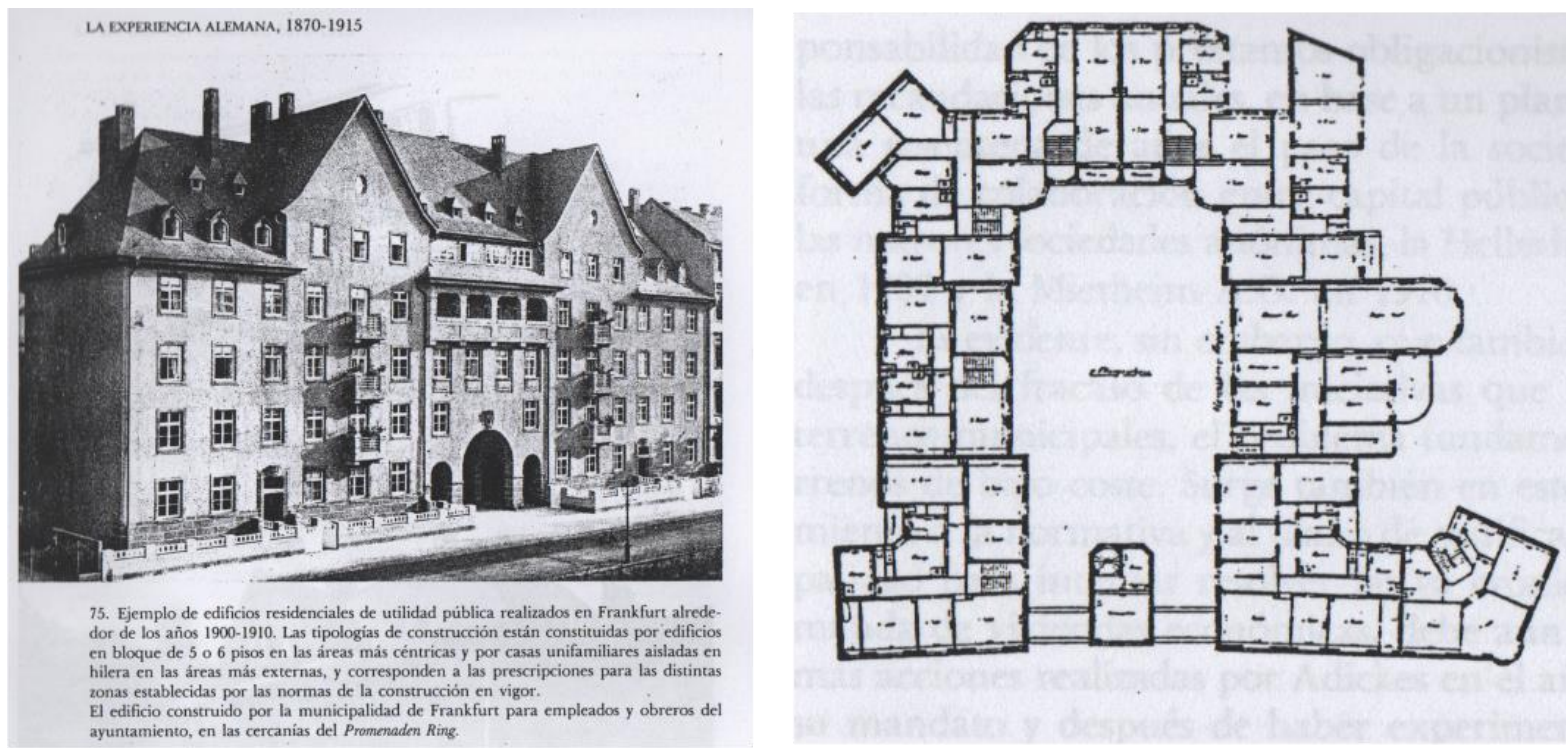

Figuras 4 e 5: Exemplos de Projetos para habitação destinada à classe trabalhadora, na primeira década do séc. XX. Fonte: Mancuso(1980) 


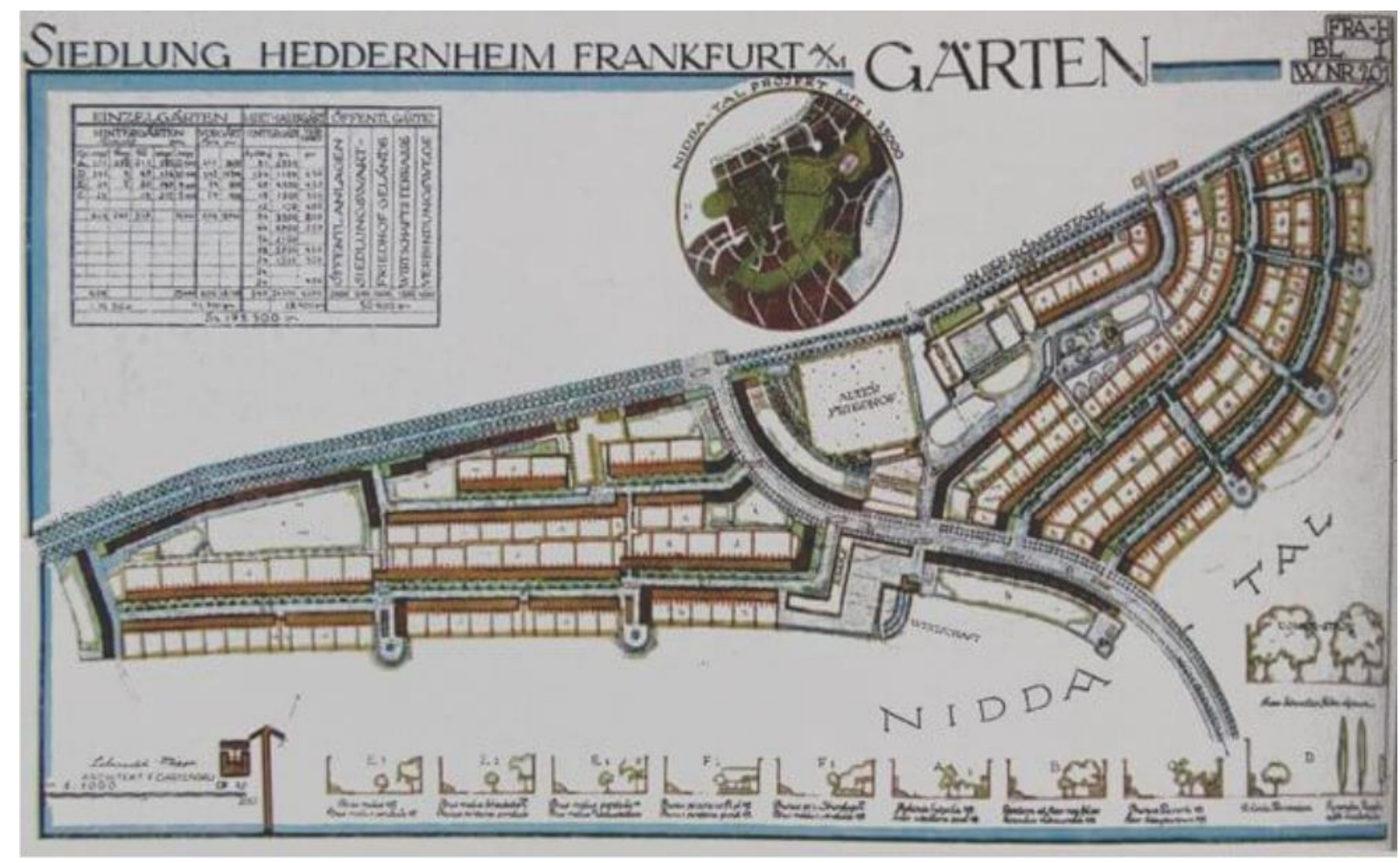

Figura 6 (acima): Projeto da Siedlung Römerstadt de 1927, com a definição das tipologias de construção, o que permite o rebatimento no plano geral, definindo a forma das zonas, que correspondem, então, à intervenção projetada. Fonte: Sociedade Ernst May (site)
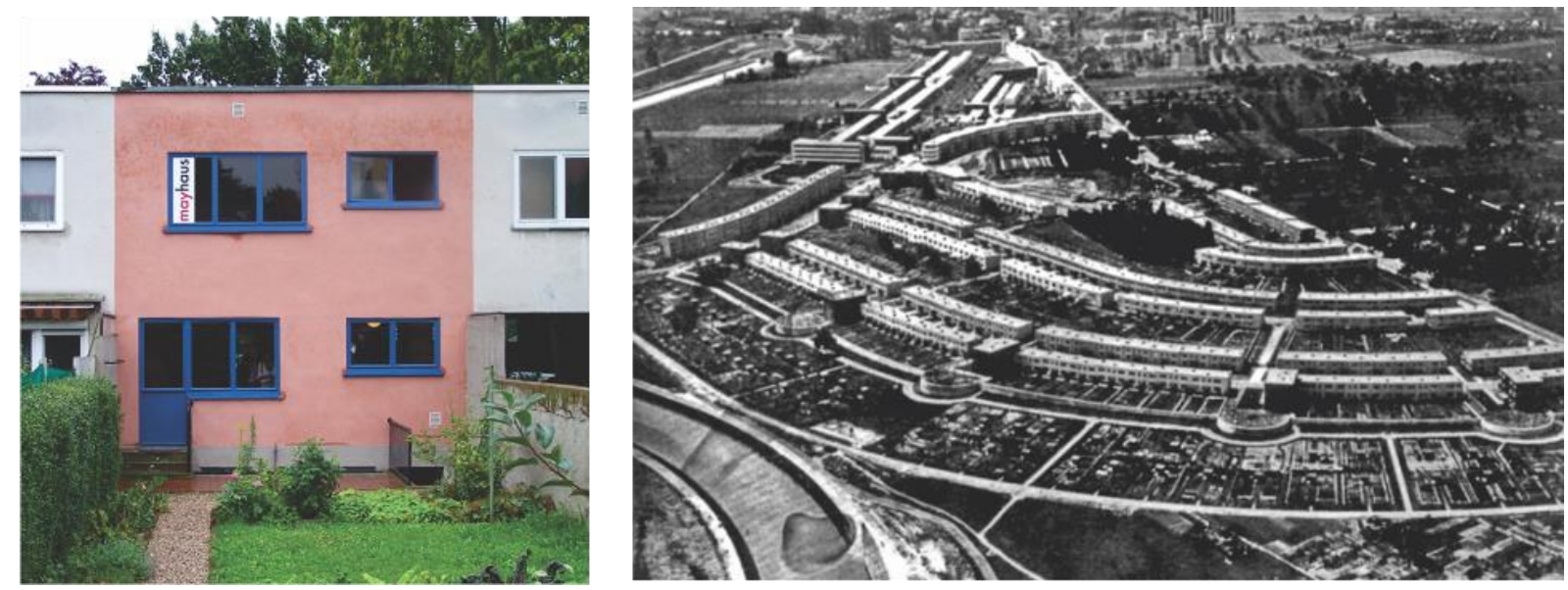

Figuras 7 (esq.) e 8 (dir.): Siedlung Römerstadt de 1927. Casa de Ernst May (hoje Museu) e vista aérea datada dos anos 30. Fonte: Sociedade Ernst May (site) 

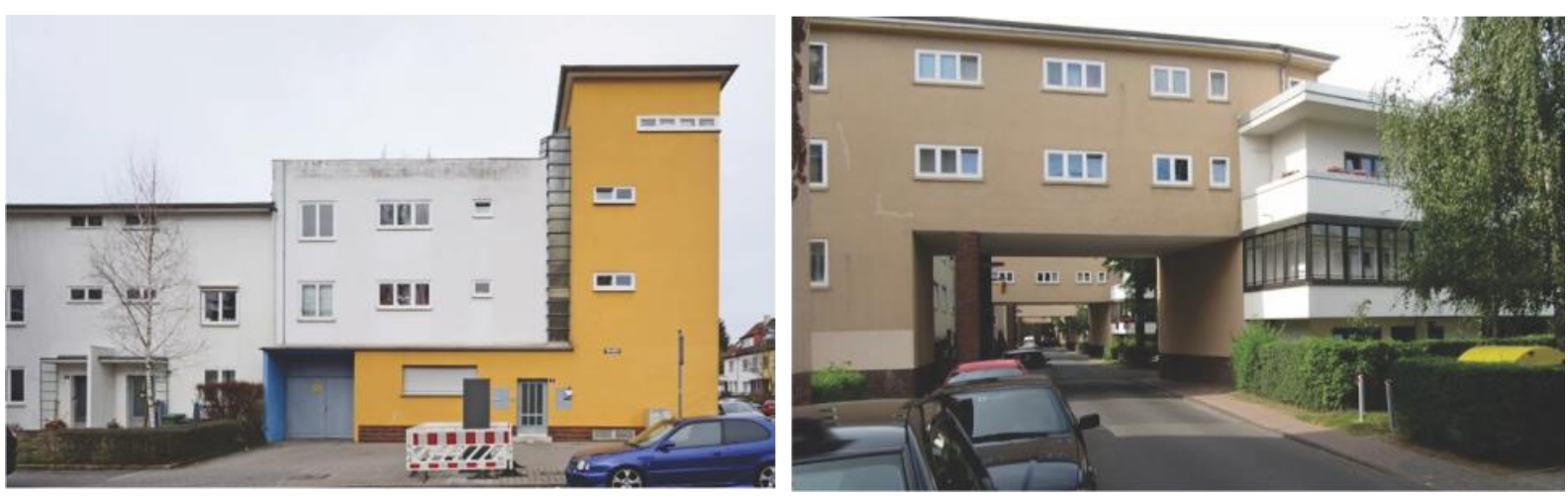

Figuras 9 (esq.) e 10 (dir.): Siedlung Hohenblick (1926) e Siedlung Riedhof West (1927-32), também projetadas por Ernst May.

Fonte: Sociedade (Gesellschaft) Ernst May (site) http://ernst-may-gesellschaft.de/

\section{3 - A Matriz Norte-americana:}

O entendimento americano sobre o zoning foca na proteção dos investimentos das classes proprietárias nas áreas mais valorizadas e em estabelecer de forma antecipada garantias para os investimentos naquelas em que se quer investir, mediando conflitos e excluindo atividades incômodas ou indesejáveis. Ao contrário da vertente alemã, que tem entre seus principais objetos de preocupação a moradia e a mobilidade das classes trabalhadoras, a concepção americana sobre o zoning dá pouca atenção ao conteúdo social.

Como já dissemos, o instrumento do zoning se disseminou velozmente pelos E.U.A., a partir da experiência de Nova York que foi a primeira cidade deste país a adotar um plano compreensivo (abrangendo todo seu território) em 1916.

Porém, outras experiência de controles de usos e densidades já estavam sendo adotadas com algum sucesso nas décadas precedentes. A própria Nova York, já em 1901, havia promulgado uma legislação de controle de cortiços, o "Tenement House Act";

Em meados da década de 1880 a cidade de Modesto, vizinha a San Francisco na Califórnia, estava enfrentando um grande aumento na imigração, com o agravante (para a sociedade da época) de que, ao contrário da costa leste onde o 
grosso da imigração à época tinha origem europeia, aqui era de origem asiática, sobretudo chinesa ${ }^{24}$.

Determinadas áreas centrais estavam sendo ocupadas predominantemente por atividades econômicas exercidas quase exclusivamente pela etnia, que tendia a se concentrar em uma mesma área (este fenômeno da concentração de uma população unida por laços étnicos, religiosos ou de idioma não é novidade nas aglomerações urbanas, sendo identificado genericamente pelo termo gueto ${ }^{25}$ ).

A cidade adota então uma divisão em duas zonas, a central e outra para além da linha férrea com a segregação da atividade das "laundries" para esta zona mais afastada, e a imediata proibição delas na área central, inclusive das já existentes. Utilizando-se inclusive do uso da força policial foram removidas cerca de 300 lavanderias de imigrantes chineses.

Ao invés de agir sobre os indivíduos da comunidade, a cidade de Modesto tenta controlar a distribuição territorial das populações chinesas adotando restrições legais sobre as edificações ocupadas pelas lavanderias (principal atividade econômica da etnia) onde também habitavam em condições precárias. Deste modo, pôde-se invocar questões de segurança (riscos de incêndio), de saúde pública (produtos químicos, odores e dejetos), enfim alegar que tal atividade traria riscos ao bem comum sendo necessário que seja disciplinada.

A justificativa da medida era assim descrita:

“[...]la localización incontrolada de lavanderias públicas, em las que se lavam ropa y otros artículos, es peligrosa y daniña para la salud y la seguridade públicas, y prejudicial para el bienestar y el confort de lacomunidad, y disminuye el valor de la propriedade em los barrios em que tales lavanderías están ubicadas[...]"(MODESTO, CA (cidade), apud MANCUSO, 1980, p.198)

\footnotetext{
${ }^{24}$ De acordo com Hobsbawn (1977, p.77): “[...] os chineses vieram para a Califórnia aos milhares. Em1849 havia 76 chineses, pelo final de 1850, 4mil; em 1852, não menos de 20 mil e por volta de 1876, havia cerca de 111 mil [...]". O preconceito com os asiáticos era tanto, que 1882 o congresso criou uma lei, o Chinese Restriction Act proibindo a entrada de "chineses, presidiários, indigentes e criminosos".

${ }^{25}$ A palavra Gueto vem do nome do bairro judeu de Veneza, o Ghetto, antiga área de fundição na ilha de Canarregio, onde a comunidade judaica de Veneza residia e tinha seus estabelecimentos. O termo passou a designar os bairros judeus por toda a Europa ainda durante a idade média (em Portugal se usava o termo "judiaria") e hoje possui uma conotação que transcende a origem, sendo aplicado com maior ou menor rigor, a qualquer vizinhança de características étnicas e/ou sociais específicas. Fontes: https://pt.wikipedia.org/wiki/Gueto ; http://venice.jc-r.net/campi/ghetto.htm
} 
Afastou-se deste modo a possibilidade de contestação judicial das ordenações Municipais pela Suprema Corte do Estado da Califórnia sendo lançados os alicerces onde se basearam todo este tipo de ordenações, que reuniam em um mesmo diploma dois princípios legislativos: primeiro, de que o desenvolvimento de uma atividade fora de uma zona em que a mesma é permitida é prejudicial aos interesses da cidade e depois, que tal violação pode ser penalizada de acordo com a lei municipal que a criou.

As municipalidades alcançam, então, o direito de regular as atividades e usos em seu território, com a Suprema Corte da Califórnia estabelecendo pela primeira vez na América o princípio jurídico do zoning.

O modelo adotado por Modesto (pouco antes San Francisco também propôs legislação semelhante) serviu para várias outras cidades da Califórnia: Los Angeles e San Diego logo emitiram ordenanças proibindo salões de baile, matadouros, aluguel de coches e muitas outras atividades com potencial de gerar conflitos de ordem social e racial (MANCUSO, 1980).

Isto é ainda mais notável em um país que tanto preza a livre iniciativa e o direito à propriedade privada, mas como veremos mais adiante é justamente a proteção aos valores imobiliários uma das maiores, senão a maior causa da aceitação quase geral que em pouco tempo o instrumento do zoning obteria na América.

A sequência natural do exemplo californiano foi a adoção por diversas cidades do sul de legislações de cunho abertamente racial, logo no início dos 1900, numa espécie de "racial zoning", onde cada quarteirão era reservado para uma ou outra categoria racial (Baltimore adotou um código deste tipo em 1910) (TALEN, 2012b; HIRT, 2014).

Em $1917^{26}$ a Suprema Corte declarou o "racial zoning" inconstitucional (TOLL, 1969, p.227), porém isto não impediu que localidades como Atlanta e St. Louis emitissem regras de ocupação tão rígidas que inviabilizavam qualquer possibilidade de cidadãos negros ocuparem determinadas áreas. Apesar de disposições raciais explícitas terem sido declaradas inconstitucionais a componente racial continuou a

\footnotetext{
${ }^{26}$ BUCHANAN versus WARLEY, 245, U.S. $60 \mathrm{em}: \mathrm{http} / /$ supeme.justia.com/cases/federal/us/245/60
} 
exercer forte influência, ainda que camuflada de restrições construtivas, nos planos de cidades americanas (especialmente, mas não somente nas cidades do sul) até pelo menos até a década de 1950. (SILVER, 1997)

Nos anos iniciais do século $\mathrm{XX}$, a $5^{\mathrm{a}}$ Avenida que era a área mais nobre de Manhattan (local de residência da plutocracia - famílias como os Carnegies, Vanderbilts e Morgans lá residiam num trecho conhecido como "millionaire row" - e de um comércio de elite), estava sendo "invadida" por imigrantes relacionados com o setor de confecção, os chamados "garment workers" (TOLL, 1969; MANCUSO, 1980).

Pequenos ateliês atraem uma enorme quantidade de imigrantes em busca de trabalho, além de outras empresas e fornecedores do setor do vestuário atraídos pela especialização da Avenida. Aumentam então o trânsito, o barulho e a poluição. Os trabalhadores ocupam os becos e as sobrelojas, usam como moradia todos os espaços remanescentes, e demandam uma grande quantidade de bares e estabelecimentos para alimentação e após o expediente, se aglomeram em grupos por toda a rua.

O prestígio da $5^{a}$ Avenida, e consequentemente o valor das propriedades, estava sendo ameaçado por esta "invasão". Como forma de reação, proprietários, banqueiros e industriais fundam em 1907 uma associação, a "Fifth Avenue Association" que assume a "defesa" da via, através de peças de publicidade nos jornais e da pressão junto às autoridades municipais. Buscam instrumentos para intervir, e seguindo os trabalhos apresentados em 1909 nas National Conferences of City Planning, indicam a possibilidade de utilização de um novo instrumento, o "zoning", que estava sendo aplicado com sucesso na Europa, notadamente na Alemanha (TOLL, 1969).

Em 1913, o City Council de Nova York envia à Alemanha uma comissão de estudos para analisar as aplicações e efeitos da aplicação do zoning. Em 1916, após três anos de estudo a cidade adota pela primeira vez um instrumento de zonificação que abrange todo seu território, inclusive as áreas ainda não edificadas.

O nome mais importante deste período é o do Advogado Edward M. Basset, cujo nome passou à história como "pai do zoning". Basset, que é reconhecido como reformador social, pela luta que empreendeu por condições mais dignas de moradia 
para as classes mais desfavorecidas, foi eleito deputado pelo partido Democrata em 1905, mas abandonou a carreira na câmara dos representantes para se dedicar a atividades em nível local, sendo apontado em 1907, pelo Governador Charles E. Hughes para a "New York Public Service Comission" onde serviria até 1911. Durante este tempo ajudou o desenvolvimento do plano do metrô de Nova York e posteriormente como chairman da comissão de Edificação apresentou o relatório que serviu de base para o plano de zoneamento de 1916.
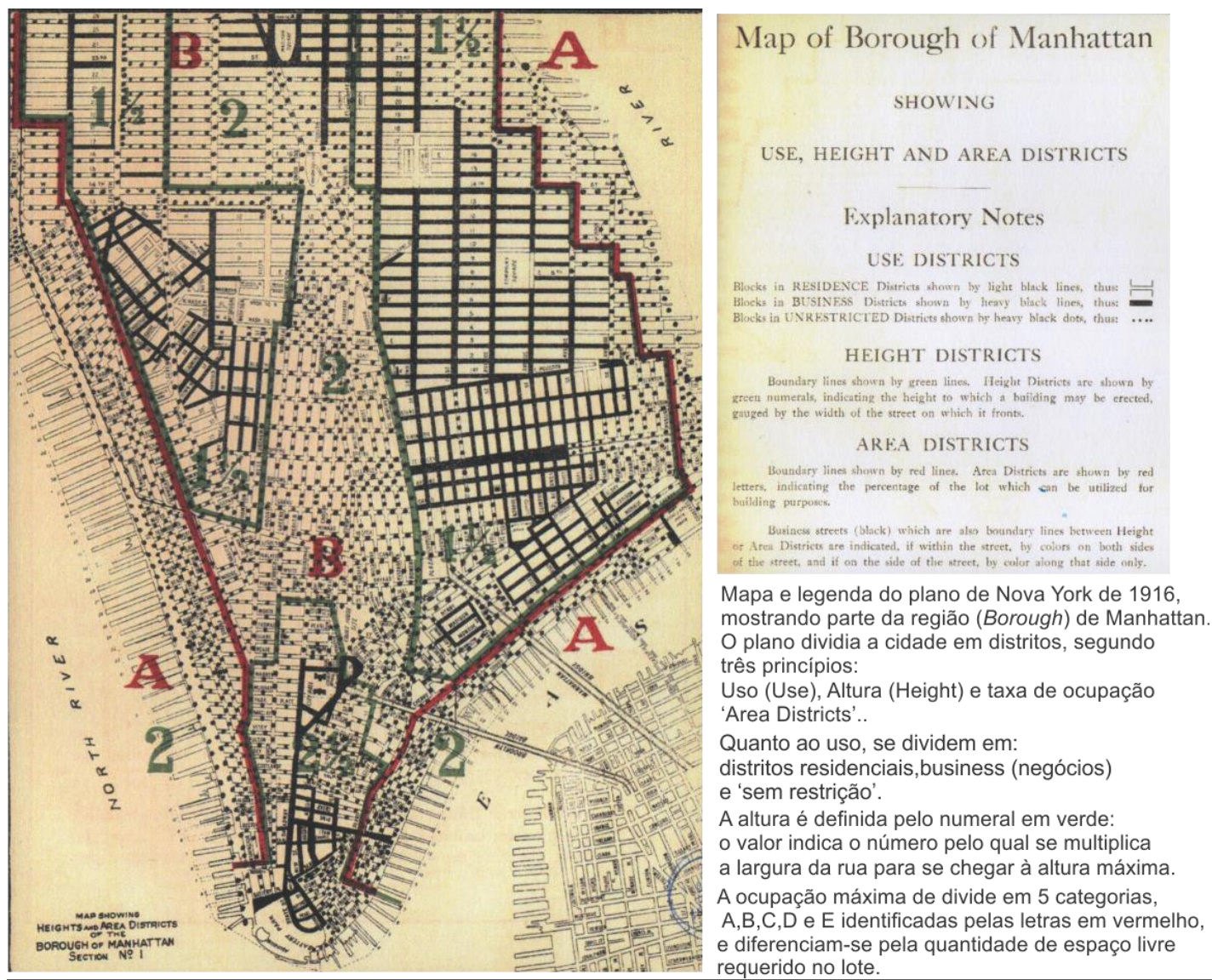

Fig. 11: NYC 1916 Zoning Ordinance Map. Fonte: a partir de Talen,( 2012a), com tradução nossa.

Outro personagem chave é o reformador social e Secretário Geral do "Commitee on Congestion of Population of New York", Benjamin Marsh, estudioso da experiência alemã com o instrumento do zoning. Em 1909, Marsh publicou o que é considerada a primeira obra norte-americana dedicada exclusivamente ao Planejamento Urbano: "An Introduction to City Planning". Conforme Toll (1969, pgs.123-125) o livro saudava a experiência de Frankfurt e advogava a adoção do instrumento do zoneamento, das taxas sobre a propriedade da terra e dos controles das áreas urbanizáveis, e da adoção de um sistema público e acessível de transportes, nos moldes das cidades alemãs. Marsh acreditava que a utilização 
destes instrumentos poderia prevenir a multiplicação dos cortiços e melhorar o acesso à moradia para as classes trabalhadoras.

Entre as novidades que o plano apresenta está o "setback", ou recuo escalonado com limitação de altura em função da largura da rua e que vai orientar a forma características dos arranha-céus tão familiares do skyline de Manhattan. A adoção deste conceito se relaciona com o problema de iluminação e ventilação colocado pelos novos edifícios que estavam sendo construído neste momento, tendo como marco a comoção provocada pelo Equitable Building, arranha-céu de 42 andares terminado em 1915.
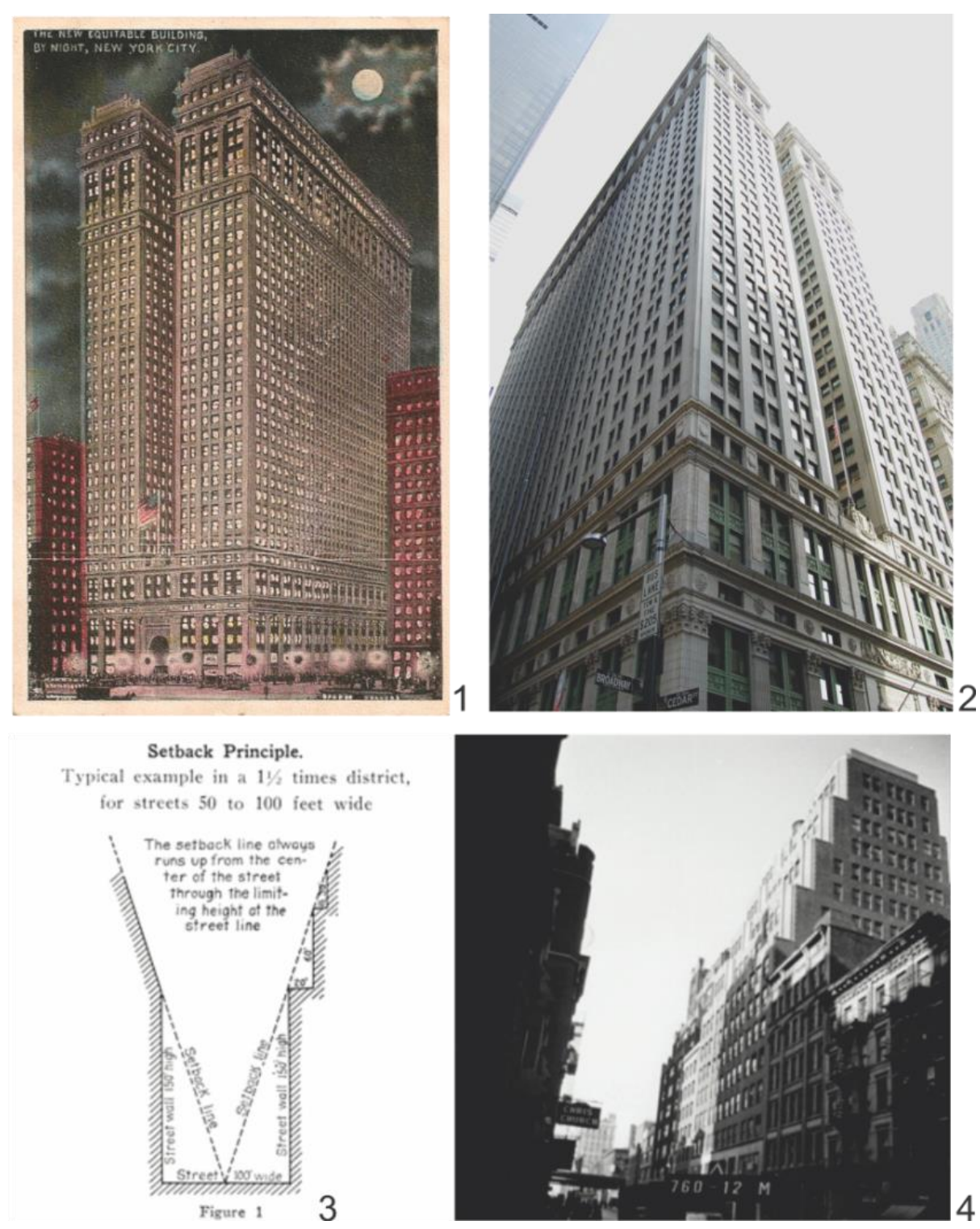

Figura 12: Equitable Building em uma ilustração da época de sua construção e foto atual (1 e 2); Ilustração sobre o princípio do setback e uma foto como exemplo (3 e 4). Fontes: Museum of the City of New York (1,2 e 4) collections.mcny.org e Mancuso (1980) (3). 

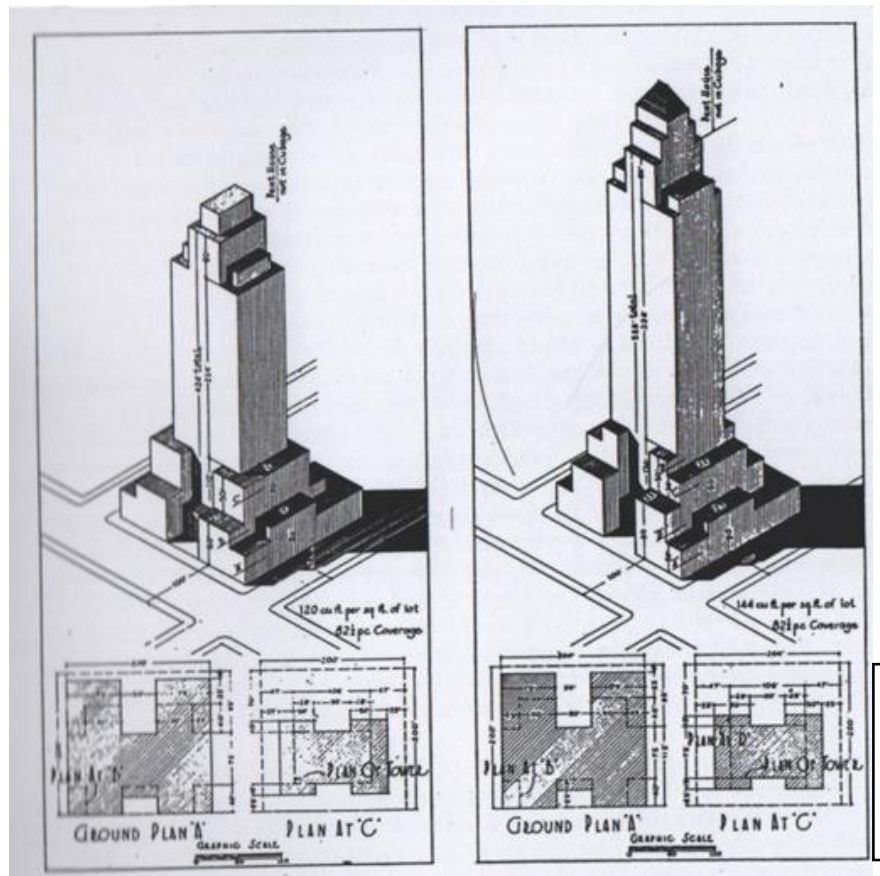

Figura 13: O padrão bolo de noiva: não havia restrição de altura para a parcela do edifício que ocupasse até $25 \%$ do lote. Fonte: Mancuso (1980).

Em termos formais, o setback é o responsável pelo desenho característico de boa parte dos arranha-céus que povoam o skyline de Manhattan, cujo formato lembra um "wedding cake", ou bolo de noiva.

$\mathrm{Na}$ verdade, o modelo americano ao invés de ser uma proposta de desenho global da cidade se parece mais com um mosaico de disposições locais, emanadas de diferentes grupos com interesses específicos como a Fifth Avenue Association. Diferentemente do modelo alemão, este modelo rapidamente tende a ser mais fragmentário e também mais sujeito a alterações pontuais de acordo com os interesses destes grupos e sua capacidade de influenciar a opinião pública e os governos locais. Segundo uma pesquisa feita pela National Zoning Conference de 1937, somente Chicago registra cerca de 1000 emendas por ano alterando disposições do código de zoneamento (TOLL, 1969; HIRT, 2014).

Hirt (2014, p.141) considera que, em um país de forte tradição individualista e avesso às interferências governamentais ao direito de propriedade, a proteção aos valor econômico das propriedades (que poderia ser atingido pela vizinhança de usos e edificações como arranha-céus, tidos como indesejáveis), a criação de espaços dentro da tradição de "individualismo espacial" e a pequena margem de discricionariedade dos agentes públicos na aplicação da legislação são a chave para entender a aceitação do zoning entre os acadêmicos e público em geral, nos Estados Unidos. 
A justificativa mais comum para a aparição do zoneamento é a necessidade de se controlar usos e densidades e impedir atividades incompatíveis em um mesmo território.

A Carta de Atenas, documento do IV CIAM - Congresso Internacional de Arquitetura Moderna, em 1933 explicita a visão dos modernistas (especialmente a de Le Corbusier) sobre a questão do zoning, da seguinte maneira:

"A zonificação é aquela operação realizada sobre a planta de uma cidade com o fim de designar a cada função e a cada indivíduo seu justo lugar. Se baseia na necessária discriminação entre as distintas atividades humana que requerem seu próprio e particular espaço: lugares para habitação, centros industriais ou comerciais, salas ou espaços destinados ao lazer."

Dizer que se deve "designar a cada função e a cada indivíduo seu justo lugar" pode ser percebido como uma intenção de se segregar não apenas as atividades ditas indesejáveis, mas principalmente os indivíduos a elas relacionados. (HIRT, 2014; MANCUSO, 1980; TOLL, 1969).

Hirt (2014, p.168-177) afirma que fica claro nos escritos do período formativo do zoning americano que a segregação racial e por renda está na raiz da supremacia das tipologias residenciais singulares. Citando diversos autores do primeiro quartel do Séc. XX, a autora demonstra a aversão de então, quanto à presença em vizinhanças residenciais unifamiliares, de atividades terciárias (por atrair indivíduos supostamente indesejáveis) e também em relação às tipologias residenciais multifamiliares, consideradas inadequadas para propiciar ambientes familiares respeitáveis.

Analisando os efeitos indesejáveis do zoning sob o viés da economia urbana, Fischel (2001) indica que a aceitação que esta ferramenta obteve nos Estados Unidos tem como explicação fundamental fatores econômicos. Ele afirma que o real propósito do Zoneamento na América era proteger os proprietários de imóveis em áreas residenciais da desvalorização causada por outros usos, como os industriais, comerciais e multifamiliares, que com o advento da mobilidade rodoviária proporcionada por caminhões e ônibus se espalhavam pelo território das cidades pondo em risco o valor de seus imóveis.

Este risco levaria os proprietários ("homeowners") a se organizarem 
politicamente como grupos de pressão sobre que o poder público para que este adote medidas que protejam seu capital da desvalorização que pode representar atividades comerciais, habitações multifamiliares, fluxos de pessoas e mercadorias indesejáveis (FISCHEL, 2001).

Outro ponto apontado pelos críticos, especialmente os ligados ao movimento "New Urbanism" (seguindo os argumentos originalmente apresentados originalmente por Jacobs (1964)), é que o modelo de zoneamento restritivo adotado nos Estados Unidos é causa fundamental da acentuação do urban sprawl, aqui chamado de dispersão urbana (DUANY, PLATER-ZYBERK, SPECK, 2000).

A enorme predominância do modelo de habitação singular em clusters monofuncionais resultou que na maior parte dos E.U.A. mesmo as funções mais básicas do cotidiano tenham de ser intermediadas pelo automóvel, com os resultados conhecidos para o meio ambiente, horas e vidas perdidas no trânsito e a perda do sentido de comunidade.

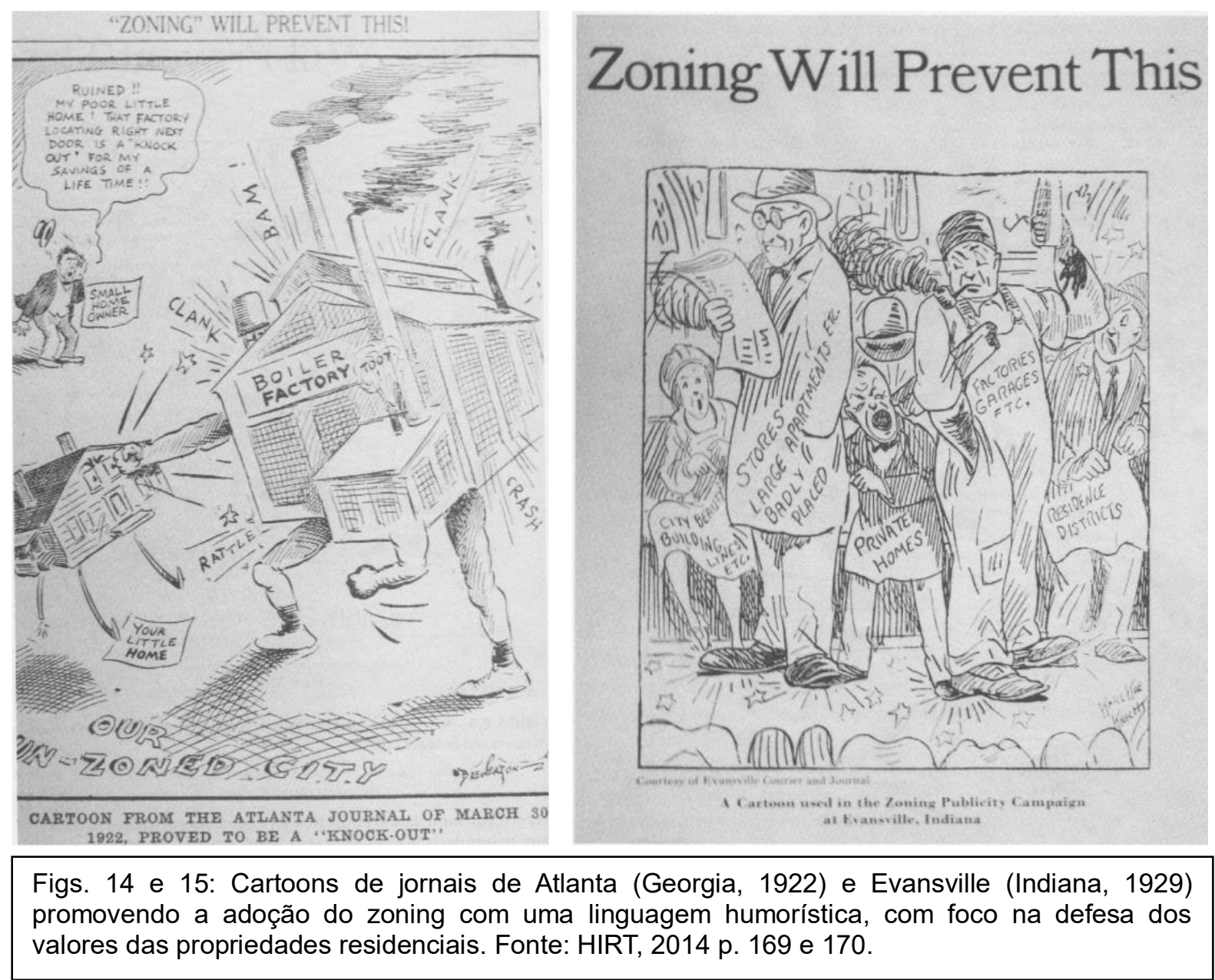




\section{4 - A influência no território paulista:}

A transformação do conceito do zoning em um modelo engessado e excludente, incapaz de acompanhar as mudanças tecnológicas, econômicas e sociais com a velocidade que se sucederam especialmente após a II Guerra, tende a acabar com a diversidade e riqueza dos espaços urbanos, principalmente ao incorporar no imaginário coletivo os ideais modernistas da separação de funções e o conceito dos "bairros exclusivamente residenciais unifamiliares".

Mesmo na América, os planos originais eram muito menos restritivos, permitindo certa mistura de usos que garantiam a autonomia do cotidiano, mesmo em distritos residenciais. O modelo restritivo com dezenas de zoneamentos excludentes e grandes manchas de zoneamento uniforme foi se consolidando ao longo do Séc. XX.

A principal consequência deste tipo de zoneamento, especialmente nas grandes cidades, foi a separação entre moradia e emprego, com os efeitos terríveis sobre a mobilidade urbana que podemos observar hoje em todas as grandes cidades brasileiras.

No Brasil a propositura de regulamentos urbanísticos ganha força a partir do final do Séc. XIX, com o viés higienista dos Códigos Sanitários. Ao propor eliminar as moradias insalubres, os cortiços (leia-se moradia das classes de menor renda) de determinadas áreas, se agia onde se identificava como "o lugar de onde emergem as epidemias". Ventilação e aeração, aliadas a densidades mais baixas são o norte destas propostas.

Exemplo cabal das consequências é a reforma Pereira Passos no Rio de Janeiro, que causou a perda do espaço popular na área central e a ocupação do morro da Providência (também conhecido como morro da Favela) que daria início ao processo de formação das favelas (PINHEIRO, FIALHO JR, 2006).

A questão da preservação do valor da propriedade se colocou muito cedo no debate sobre a legislação pertinente. Inicialmente filiada à tradição do urbanismo higienista francês, logo une a estas preocupações sanitárias a preocupação com o rendimento da terra. 
Rolnik, (1997) ao analisar o pensamento de Vitor da Silva Freire (Eng ${ }^{\circ}$ formado na França e que dirigiu o setor de obras da cidade de São Paulo por 37 anos, entre 1899 e 1926) demonstra como ele foi influenciado por pelo planning norte-americano, especialmente pelo trabalho de Lawrence Veiller para a Russell Sage Foundation ${ }^{27}$ de 1914 e na legislação urbanística baseada no zoning que se espalhava pelos Estados Unidos na década de 1910.

Citando a obra de Veiller apresentada na Segunda Conferência de Planejamento da Cidade da Filadélfia em 1911, Freire defendeu a adaptação da técnica imobiliária às propostas higienistas, ou seja, pensar a higiene e o rendimento simultaneamente. Para tanto propõe a utilização de embasamentos (desde que bem aerados e iluminados, diferenciando-os dos porões) para habitação, diminuição de pés-direitos e aumento do número de andares das construções:

"Baixados os pés-direitos, utilizados os subsolos em condições aceitáveis, não seria a população que se revoltaria contra uma transformação que desde logo the assegurava allivio imediato no bolso ${ }^{\text {,28 }}$ (SILVA FREIRE, 1918 apud ROLNIK,1997, p.45).

Freire, apesar de inteirado do debate sobre as experiências com o zoneamento na Europa e nos Estados Unidos, acredita que o meio brasileiro ainda não está preparado para absorver tal forma de organização da cidade: “[...]o nosso meio parece-me crú ainda para este progresso, que constitue a verdadeira orientação da legislação sanitária" (Ibidem).

$\mathrm{Na}$ introdução de sua obra sobre a formação da legislação urbanística em São Paulo, Rolnik (1997, p.14) afirma seus princípios se consolidaram no período entre 1886 (data do Código de Posturas Municipais) e 1936 (Primeira Lei de Anistia geral às construções irregulares):

“[...]foram formulados alguns princípios presentes até nossos dias na legislação urbanística paulistana: a muralha protetora em torno dos

\footnotetext{
${ }^{27}$ A Russel Sage Foundation é uma fundação que tem por objetivo "a melhoria das condições de vida no Estados Unidos" e o desenvolvimento das Ciências Sociais, apoiando pesquisas na área. Fundada em 1907, em seus anos iniciais desenvolveu projetos nas áreas de habitação para baixa renda, planejamento urbano, assistência social e reformas trabalhistas. A Fundação atualmente se dedica a fortalecer a pesquisa científica na área das Ciências Sociais, como meio de diagnosticar e melhorar problemas e políticas sociais. Fonte: sítio da fundação: www.rusellsage.org

${ }^{28}$ Texto de Vitor da Silva Freire para o Boletim do Instituto de Engenharia em fevereiro de 1918.
} 
bairros residenciais de elite, a posição eternamente periférica dos bairros populares, a concentração dos investimentos e a superregulação do centro-sudoeste da cidade, a expansão horizontal de baixa densidade."

O estudo da concepção de zoneamento norte-americana é de suma importância para entendermos a construção das ideias sobre zoneamento na cultura urbanística brasileira. Feldman (2005) dedica um capítulo inteiro de seu livro sobre a relação entre planejamento e zoneamento em São Paulo no período de 1947-1972 para analisar a influência do pensamento urbanístico norte-americano na atuação do Departamento de Urbanismo da Prefeitura de São Paulo.

Para Feldman a preponderância do instrumento do zoneamento é tamanha que na verdade, o termo zoneamento acaba por se tornar sinônimo de Planejamento, ocupando o lugar do Plano.

Já Vilaça (2010, p.177) considera que o zoneamento, entendido como " $a$ legislação urbanística que varia no espaço urbano" aparece no Brasil de forma independente no Rio de Janeiro e São Paulo, nas últimas décadas do Séc. XIX, desprovida de qualquer fundamentação teórica, correspondendo apenas a soluções e interesses específicos das elites brasileiras ${ }^{29}$.

O autor afirma ainda, que o zoneamento aparece nos planos diretores sempre de forma vaga e pouco operacional, ao contrário das leis específicas de zoneamento, separadas dos planos e que são aplicadas quase sempre para atender a interesses específicos dos bairros das populações de mais alta renda. Segundo este autor:

\begin{abstract}
"A história do zoneamento é totalmente distinta da história do planejamento urbano stricto sensu, e até hoje predomina o zoneamento separado do plano diretor (embora no discurso, se afirme que o zoneamento é parte integrante de um plano diretor). Esta é a razão pela qual o zoneamento é a prática de planejamento urbano
\end{abstract}

\footnotetext{
${ }^{29}$ Evidentemente, o Prof. Vilaça está se referindo a disposições específicas e restritas a determinadas atividades e/ ou localizações dentro da cidade. O Zoneamento compreensivo, sobre a totalidade do território da cidade, nos moldes de Nova York (1916) somente foi adotado em São Paulo em 1972 (FELDMAN, 1997; 2005; ROLNIK, 1997) e consolidado no Rio de Janeiro em 1976 (BORGES, 2007), ainda que se possa considerar o Código Saboya (1929) e o Ato 127 (1931) em São Paulo e o Decreto n 6.000 de 1937 (Código de Obras do Distrito Federal) no Rio de Janeiro como importantes marcos iniciais.
} 
lato sensu mais difundida no Brasil” (VILAÇA, 2010, p.178).

Feldman (1997) aponta que o entendimento sobre o zoneamento que se consolida em São Paulo a partir dos anos 40 apresenta três características que o definem: Em primeiro lugar, deve ter caráter compreensivo, isto é se entende como um instrumento de planejamento que regule a utilização do solo urbano em toda a área da cidade; diferentes regras se aplicam a diferentes partes da cidade, de modo sistemático; e, finalmente, explicita os seus objetivos de proteção aos valores imobiliários, controlando os processos econômicos ligados à utilização do solo urbano.

A preservação do valor da terra como finalidade do zoneamento pode ser observada no pensamento dos dois principais expoentes que polarizaram o debate sobre urbanismo entre as décadas de 20 e 60 em São Paulo e cujas obras exercem influência que até hoje se faz presente: Anhaia Mello e Prestes Maia. Apesar de suas concepções divergentes sobre urbanismo e progresso, ambos se aproximavam na noção que tinham sobre a real função do zoneamento.

Enquanto Anhaia Mello afirmava que:

“[...]O zoning, portanto não é restrição, é uma garantia, um princípio fundamental para a salvaguarda dos direitos dos proprietários urbanos.” (MELLO, 1929, p.113).

Prestes Maia tecia as seguintes considerações:

“Em São Paulo, como aliás em muitas outras cidades, o cidadão que empata boa porção de sua fortuna na construção de um lar ou mesmo de um prédio para renda, nunca está seguro no dia seguinte. Quando menos espera, um arranha-céu erigido ao lado de seu palacete virá esmagá-lo. Uma fábrica, com seu ruído e chaminés, afugentará os inquilinos dos seus apartamentos. Um armazém, um açougue, uma garagem ou um cortiço depreciarão seus prédios. Só o zoneamento poderá remediar isto, introduzindo ordem nas construções, especialização nos bairros e organização em toda a cidade" 30 (MAIA, 1936, p.2 apud ROLNIK, 1997 p.191).

\footnotetext{
${ }^{30}$ MAIA, Francisco Prestes . O zoneamento urbano. São Paulo, Sociedade Amigos da Cidade,1936 p.2.
} 
É este entendimento do zoneamento, aliado à incorporação do ideário modernista com a separação total das funções preconizada pela Carta de Atenas, que influenciou a conformação da legislação urbanística no Brasil.

Outro ponto fundamental para compreendermos a importância que o zoneamento alcançou em todas as esferas de discussão sobre as cidades brasileiras é a sua capacidade de criar valor (especulativo) sobre o valor original de um imóvel, e daí se origina sua centralidade na maioria das disputas dos diversos interesses em luta pelo espaço urbano.

O zoneamento pode agir de duas maneiras sobre a questão dos valores:

Passivamente, preservando uma determinada área da invasão de atividades ou indivíduos que possam depreciar o valor do solo, como já vimos anteriormente.

Ou então, ativamente, através da simples mudança na legislação de modo a permitir novos tipos de uso e ocupação, especialmente ao conferir maiores coeficientes de aproveitamento a um imóvel, quadra, ou área maior da cidade, através das emendas (Decretos e Leis de alteração de Zoneamento), sempre a reboque de interesses particulares de indivíduos e grupos específicos.

Exemplificando: sendo o objetivo real a multiplicação do valor da terra pela mudança do Coeficiente de Aproveitamento, no caso de Campinas uma mudança de Zona 3 para Zona 13, significa no mínimo aumentá-lo de 1 (uma vez) para 3 (três vezes a área do terreno), podendo chegar a 4 , no caso da tipologia CSE-4, prevista pela LUOS.

No caso do terciário, as mudanças de zoneamento podem estar relacionadas a um movimento especulativo, introduzindo determinados usos de modo a aproveitar as características locacionais de terrenos, seja pelo baixo preço buscando uma valorização da terra ou para agregar rendimento a terrenos cujo zoneamento original (por exemplo, áreas estritamente residenciais), não remunera de modo atrativo o valor deste terreno.

Estas alterações de zoneamento podem também ser um reconhecimento da mudança de determinadas dinâmicas urbanas, em porções do território onde o uso permitido não condiz mais com a realidade, e muitas vezes são a única ferramenta de intervenção que o poder público pode fazer uso em cidades cuja regulação 
urbanística é demasiadamente engessada.

A grande questão que se coloca é como identificar e separar as alterações de fundo especulativo daquelas destinadas a melhor organizar e reconhecer o território da cidade e, sobretudo, se isto é possível de ser feito em um ambiente de grandes disputas econômicas e ideológicas.

Cândido Malta (2001.p.48) define a especulação imobiliária da seguinte maneira:
"Como se sabe, a especulação imobiliária urbana, de um modo geral
é, no quadro do capitalismo, uma forma pela qual os proprietários da terra recebem uma renda transferida de outros setores produtivos da economia, especialmente através de investimentos públicos na infraestrutura e serviços urbanos, que são os meios coletivos de produção e consumo ao nível do espaço urbano[...]Esse ganho, oriundo de uma melhoria pública é aquele que definimos como especulativo, pois não derivou de investimentos de seu proprietário, $e$ sim, da coletividade”.

Já há muito tempo, aqueles que lucram com a especulação descobriram os mecanismos de mudanças pontuais na legislação de uso e ocupação do solo dentro do sistema de zoneamento, como forma de criar valor, seja através das mudanças de coeficiente de aproveitamento ou ao conferir a possibilidade de novos usos em áreas mais restritas.

E este valor é criado sem a necessidade de investimentos concretos, exceto aqueles no sentido de influenciar a opinião pública propagandeando supostas vantagens coletivas de uma eventual alteração da lei, ou de modo mais silencioso (e mais típico, numa sociedade patrimonialista), ao influenciar os donos da caneta. 


\section{CAPÍTULO 2}

\section{A Dinâmica do Setor Terciário}

Primeiramente, gostaríamos de mencionar a dificuldade de se encontrar bibliografia referente à relação do setor terciário (comércio e serviços) e seu rebatimento espacial. Neste sentido, a formulação deste capítulo lastreia-se, fundamentalmente, nos trabalhos de Heliana Comin Vargas, permitindo-me fazer as reflexões necessárias para dar conta das análises referente ao setor terciário e a legislação de uso e ocupação do solo na cidade de Campinas.

O setor terciário é o setor pelo qual a produção se consubstancia em mercadoria, adquirindo valor de troca (comércio), e fornece recursos à produção e ao consumo (serviços), incluindo o próprio processo de criação. (VARGAS, 1985)

Divide-se em diversas categorias, compreendendo não apenas o comércio varejista e atacadista, mas também a prestação de serviços, as atividades de educação, cultura, lazer, turismo, sistema financeiro e atividades administrativas, públicas e privadas. (VARGAS, 2001)

Segundo Vargas (2001), podemos definir o setor terciário como aquele que incorpora atividades que não produzem nem modificam objetos físicos (produtos ou mercadorias), sendo que estas atividades possuem alto grau de efemeridade, e ausência de corporeidade, isto é, se esgotam no momento do ato da troca, não se materializando em nenhum novo produto.

A origem das atividades terciárias está intimamente ligada à própria origem dos assentamentos humanos, como lugar do encontro e das oportunidades de troca:

"Desde o inicio das civilizações, comércio e cidade têm uma relação de simbiose. Ou seja, não tem significado e definham quando separadas. Ambos são causa e efeito da mesma centralidade que pressupõe o encontro do fluxo de pessoas, mercadorias, ideias e mensagens" (VARGAS, 2000 p1).

"[...] em nenhuma civilização a vida urbana floresceu sem a presença das trocas. O comércio faz parte da razão de ser da cidade. Viabiliza 
sua existência, explica sua organização e justifica muito do movimento e animação que nesta acontece. Por meio do comércio e dos lugares onde este se exerce, as pessoas satisfazem necessidades, realizam desejos, veicula-se informação, difundem-se inovações, criam-se laços de sociabilidade. Em suma, no comércio reside o verdadeiro embrião da vida urbana naquilo que esta pressupõe de interacção, de troca em sentido lato e de produção de inovação. [...] as relações entre a cidade e o comércio são dinâmicas e fundadoras em ambos os sentidos [...] O comércio faz cidade ao atrair clientes e mercadorias, ao vivificar determinadas áreas e precipitar o declínio de outras, mas a sua evolução, do ponto de vista econômico e espacial, é também influenciada pelas mudanças da sociedade, a transformação de valores e estilos de vida, a evolução dos aglomerados e as metamorfoses da estrutura urbana"(CACHINHO; SALGUEIRO, 2009 p.9-10).

A partir dos anos 70, as mudanças econômicas globais criaram um cenário onde a importância do terciário nas grandes cidades, em termos de geração de riqueza e absorção da mão-de-obra, começa a sobrepujar a produção manufatureira, produção esta que foi afetada ainda mais pela globalização e pela ascensão do capital financeiro como principal motor do capitalismo, em substituição ao modelo fordista-taylorista. Neste momento, trabalhos como da de Saskia Sassen (1998) sobre cidades globais, vão direcionar o olhar para o setor terciário, marcado pelo que chamou de serviços produtivos, ou seja, aqueles direcionados a servir empresas, o que já fora definido anteriormente por Rochefort (1976) quando classificara o terciário como atendendo a indivíduos ou a empresas (produtivos) Vargas (2001).

A produção industrial se desloca para países ou áreas onde a mão-de-obra é mais barata, permanecendo nos centros mais desenvolvidos as instâncias de pesquisa, administração e controle, enquanto que o crescimento da economia dos serviços, especialmente os ligados às áreas de finanças, marketing e administração resulta no aparecimento das cidades mundiais. (VARGAS, 2001 p.51)

Estas mudanças consolidam um cenário em que as oportunidades de emprego tendem a se concentrar cada vez mais no setor terciário, com previsões de 
que até 2.100 atingirá $80 \%$ do total de postos de trabalho (HEALEY ${ }^{31}$, apud VARGAS, 2001). Nas grandes cidades este cenário já é uma realidade. Em Campinas, segundo dados de 2014 da ACIC, Associação Comercial e Industrial de Campinas, o setor terciário representa $89 \%$ do total de empresas instaladas no município, concentrando $72,57 \%$ dos empregos formais.

Healey (1990 apud Vargas, 2001) cita entre os principais fatores para o crescimento do emprego no setor de serviços o aumento na demanda por consumidores devido ao enriquecimento das sociedades; a subcontratação (terceirização) em áreas como limpeza, segurança e contabilidade; o aumento da internacionalização dos serviços, taxa de aumento da produtividade inferior à do setor industrial e o aparecimento de novas atividades derivadas dos avanços tecnológicos.

A diversidade de atividades que compõem o setor terciário e a diversidade de seu público alvo, não permite a definição de parâmetros rígidos e homogêneos para o seu desenvolvimento. A atratividade comercial de um imóvel, em especial, depende de uma série de fatores que na maioria das vezes passam despercebidos, ou desconhecidos, pela gestão urbana e da legislação que a orienta. Ela varia de acordo com o tipo de mercadoria ou serviço a ser ofertado, do perfil e da quantidade de consumidores, ou seja, do binômio densidade/renda. No caso do comércio e serviços varejistas de uso cotidiano, de alimentação, padaria, supermercado, por exemplo, os fatores densidade de fluxo e de renda são fundamentais, o que já não é tão importante para um produto ou serviço mais especializado cuja compra é programada (roupa de noivas ou serviços médicos, por ex.), ou mesmo para o varejo de grande porte (hipermercados, home centers, shopping centers) que têm, por si mesmos, a capacidade de criar localizações e atrair fluxos (Vargas 1992).

Avenidas que apresentam grande fluxo de veículos e pessoas, por mais que estejam localizadas em bairros em que a legislação de uso e ocupação do solo defina como sendo estritamente residenciais, tendem a se tornar corredores comerciais ou de serviços (fig. 16). A criação dos chamados corredores, a partir da legislação de uso e ocupação do solo de São Paulo, de 1972, foi um claro exemplo

\footnotetext{
${ }^{31}$ HEALEY, M.J. \& ILBERY, B. W. Location \& change: perspectives on economic geography. Nova York: Oxford University, 1990 .
} 
destas ocorrências, como forma de ajuste das restrições.
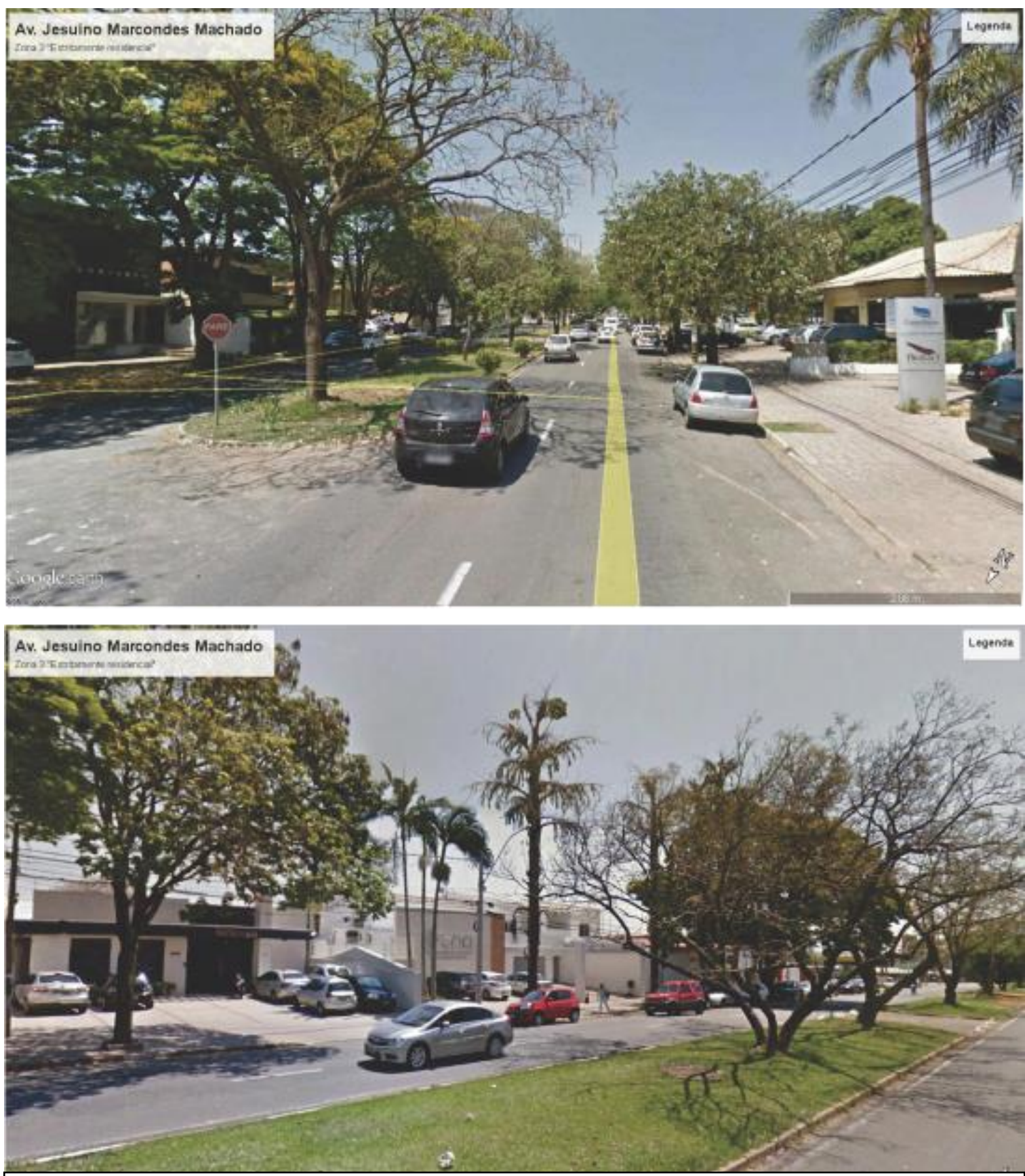

Figuras 16 e 17: Imagens da Av. Jesuíno Marcondes Machado na Nova Campinas. Apesar de todas as restrições na Lei de Uso e Ocupação, como toda Avenida de grande fluxo há a tendência de ocupação pelo terciário. Em levantamento realizado em fev/2015 verificou-se que apenas 3 de 79 imóveis ainda conservam o uso residencial (vide Cap.4). Fonte: a partir

Vargas (2001) coloca que a lógica espacial perseguida pelo setor terciário é a busca da centralidade. Segundo a autora, esta centralidade se configura como: "o local de encontro de fluxos de toda ordem - pessoas, mercadorias, veículos, informações reunindo uma variada quantidade de atividades terciárias (comércio e serviços, cultura, lazer, educação, saúde, administração pública, turismo, etc.)”. E, que nesta busca pela 
centralidade pelos agentes envolvidos nas atividades terciárias, se ela não existe será procurada, e se não existir deverá ser criada.

Neste sentido Vargas identifica como agentes que atuam significativamente (ainda que de modo distinto) sobre o espaço urbano e regional, o pequeno comerciante, o grande varejista e o empreendedor imobiliário: cada um a sua maneira irá interagir com o espaço urbano (Vargas, 2000).

Se para o pequeno comerciante o fluxo de pessoas é o principal foco de atuação, procurando situar-se na proximidade destes fluxos, o grande varejo como os hipermercados, home centers e as lojas de departamentos têm a capacidade de criar estas centralidades internamente e eventualmente podem, inclusive, funcionar como indutor da urbanização. Os casos de grandes empreendimentos imobiliários têm, por sua massa crítica, capacidade de criar centralidades onde estas não existam previamente. Estamos aqui nos referindo especialmente aos Shoppingcenters que são, na verdade, empreendimentos varejistas de base imobiliária ${ }^{32 ; 33}$.

A estes, soma-se um quarto agente de fundamental importância por sua capacidade de criar fluxos, que é o poder público em todas as suas instâncias. Daí a necessidade de o setor público compreender melhor os efeitos no meio urbano quando decide pela instalação de um equipamento ou órgão de atendimento ao público, procurando balizar tecnicamente suas escolhas locacionais, seja como controle ou como fomento da geração de fluxo.

Vargas $\left(2014\right.$, p.49) ${ }^{34}$ define localização como:

"a reunião de atributos locacionais de um ponto do território que: definem suas possibilidades de relacionamento com os demais pontos deste território; incluem condições ambientais e paisagísticas; e apresentam marcas de status, tradição e cultura. É o produto do trabalho e da inversão sucessiva de capital dispendido na construção

\footnotetext{
${ }^{32}$ Para saber mais sobre shopping centers ver: Garrefa (2011).

${ }^{33}$ No caso deste tipo de empreendimento a administração centraliza inclusive a escolha do mix de lojas e serviços ofertados, bem como as estratégias de marketing em comum. O foco é o retorno do investimento do empreendedor imobiliário (a administradora do Shopping) e não o retorno para o lojista.

${ }^{34}$ Vargas complementa deste modo a definição original de Flávio Villaça em "A localização como mercadoria" (Apostila da FAU-USP. São Paulo. FAU-USP, 1978), cujo texto original trazia a seguinte redação: “[...] ] reunião de atributos locacionais de um ponto do território que definem suas possibilidades de relacionamento com os demais pontos deste território. É o produto do trabalho e da inversão sucessiva de capital dispendido na construção da cidade e que pode ter origem externa ao espaço fisico que lhe dá suporte".
} 
da cidade e da sua imagem, podendo ter origem externa ao espaço fisico que lhe dá suporte e ser planejadamente criada pelo próprio capital ou pelo estado".
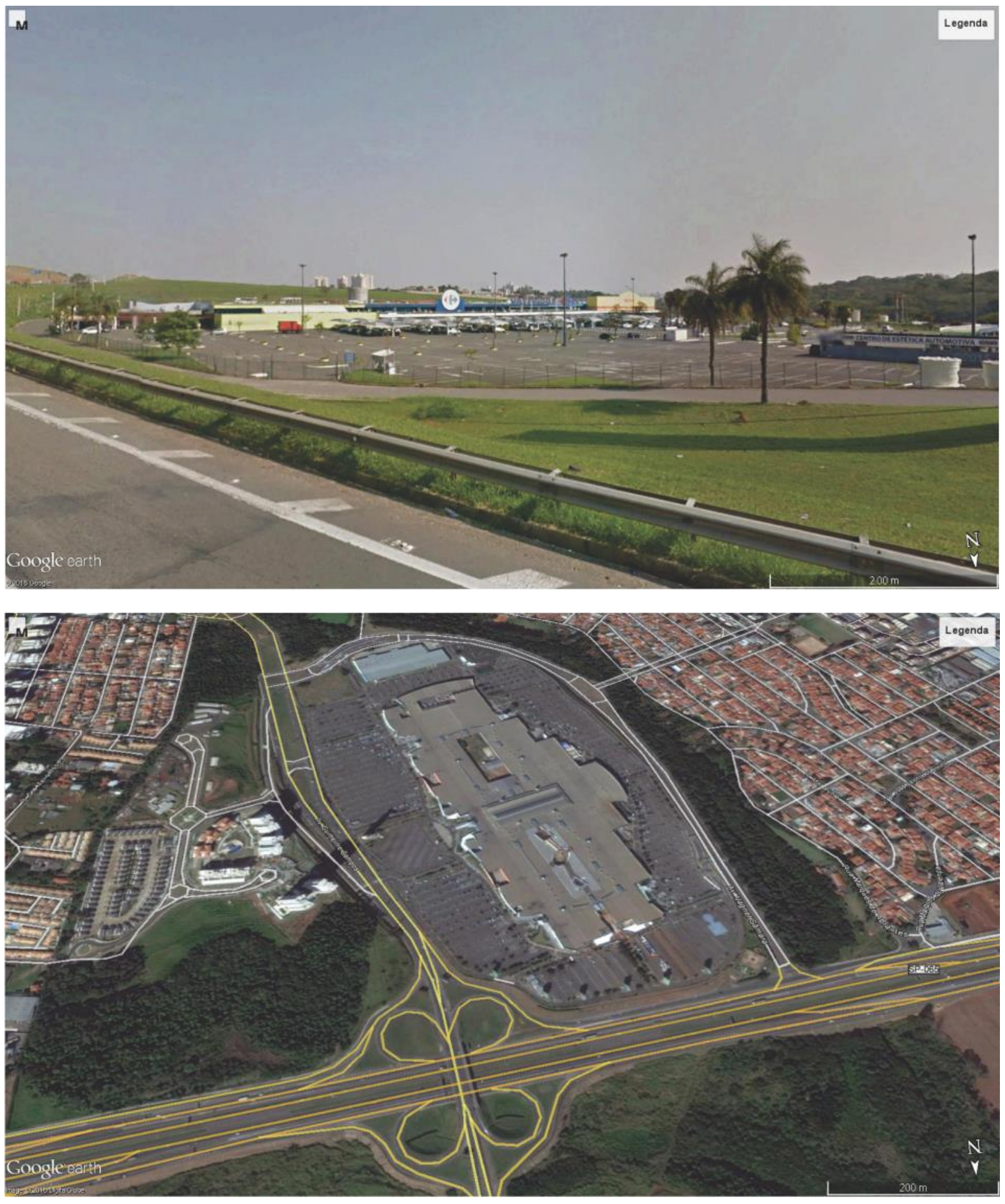

Figuras 18 e 19: Grandes empreendimentos varejistas no eixo da Rod. D. Pedro I. Hipermercado Carrefour (1979) e Shopping D. Pedro (2002). Este tipo de empreendimento tem, por sua escala, a capacidade de criar sua própria centralidade. Fonte: a partir de Google Earth Pro. 
Segundo Healey (1990 apud Vargas, 2001 p.49), estabelece-se uma relação de mão dupla entre mudança econômica e localização. Num mundo em acelerada transformação, onde atividades, produtos, lugares e edifícios se tornam obsoletos tão rapidamente como são criados, o tecido urbano das grandes cidades é afetado por estas mudanças numa velocidade que dificilmente a legislação urbanística pode acompanhar. Áreas já edificadas apresentam ainda uma condição inercial, respondendo de maneira muito mais lenta a estas mudanças.

Este é um movimento que tende a se acelerar cada vez mais, exigindo do poder público, maior capacidade na leitura do que acontece no território que administra, de compreensão das dinâmicas próprias do setor terciário e suas demandas locacionais, e agilidade nas respostas a estas mudanças, não podendo ficar preso ao imobilismo dado por um modelo de zoneamento monofuncional, estático no tempo.

Um texto recente, produzido por Vargas (2015), como um ensaio sob o titulo "Localização comercial não se define por decreto", aponta vários mitos relacionados ao comércio que lideram o pensamento sobre a atividade comercial e de serviços. $\mathrm{O}$ primeiro deles mencionado é sobre a sua suposta capacidade de gerar fluxos. $\mathrm{Na}$ verdade, o que ocorre é justamente o contrário, a existência de fluxos num primeiro momento é que exerce atração sobre as atividades comerciais e de serviços. Segundo a autora, o comércio e os serviços é que vão atrás de seus potenciais consumidores e onde houver uma intensidade de fluxo significativa, vai aparecer uma oferta. Apenas num segundo momento, após a consolidação de uma concentração significativa de negócios é que há a possibilidade desta área concentrada se tornar, por sua vez, indutora de fluxos, como no caso das ruas de comércio especializado, ou mesmo áreas maiores como o bairro do Brás e a região da Rua 25 de março.

A qualificação do tipo de fluxo, definida por fatores como renda, faixa etária, ou tipo de uso do entorno, determina o tipo de comércio ou serviço que se instala em cada área. Uma concentração de edifícios de escritórios tenderá a concentrar em seu entorno, atividades relacionadas como serviços de alimentação (bares, 
restaurantes e lanchonetes), copiadoras, lavanderias livrarias etc. ${ }^{35}$ Do mesmo modo, terminais de transporte coletivo concentram comércio e serviços com perfil mais popular, cuja oferta tem preços mais baixos do que na periferia, atraindo inclusive uma grande quantidade de comércio informal, como vendedores ambulantes e camelôs. Outro exemplo desta relação entre o tipo de fluxo e o comércio gerado pode ser visto na dissertação de mestrado de Guerra, (2015), que analisa o entorno da estação Conceição do metro de São Paulo.

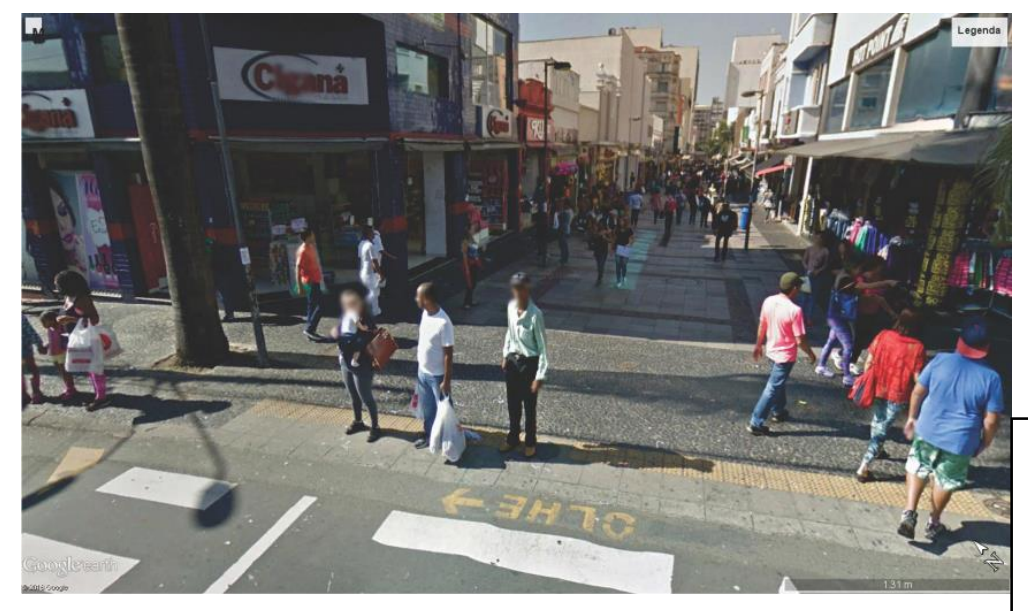

Figuras 20 e 21: Imagens de comércio popular varejista tradicional na Rua 13 de Maio: "calçadão" inaugurado em 1975, tem fluxo diário

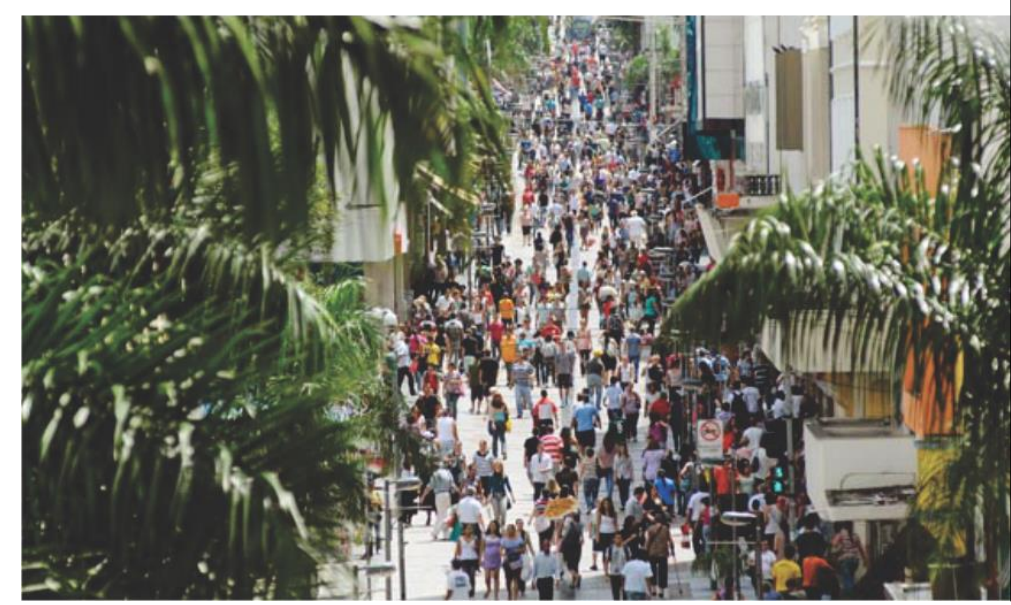
médio de cerca de 100.000 pessoas, segundo dados da ACIC. A rua, com cerca de $800 \mathrm{~m}$ de extensão, liga a praça da catedral Metropolitana com as estações ferroviária e rodoviária, além de receber os fluxos de quatro terminais de ônibus urbanos em suas imediações.

Fontes: Google Earth Pro (alto) e DECON/PMC (embaixo)

Ainda, conforme Vargas, (2015), outro ponto mal compreendido pelo público em geral e pelos responsáveis pela elaboração de legislações e normas urbanísticas, é a diferença entre comércio e serviços e entre os diversos subtipos

\footnotetext{
${ }^{35}$ Um exemplo interessante em Campinas foi a mudança das varas do fórum central para a "Cidade Judiciária", antigo prédio do DER, próximo à confluência das Rodovia D. Pedro I e Ademar de Barros, na Saída para Mogi-Mirim: ocorreu um esvaziamento nas salas comerciais que se concentravam na região central, próximo ao antigo Palácio da Justiça, o que por seu turno contribuiu inclusive para a estagnação das áreas comerciais no entorno.

De modo inverso, quando em 2007 o Fórum Trabalhista se instalou em uma torre comercial na Av. José de Sousa Campos, aumentou a procura por imóveis para escritórios de advocacia, estacionamentos, copiadoras e afins, no entorno deste prédio, o qual, apesar de estar em uma avenida de grande fluxo, fica no limite de um bairro que a legislação de uso e ocupação do solo define como estritamente residencial.
} 
em ambas as categorias, cujas demandas e especificidades diferem muito nos aspectos arquitetônicos e em sua relação com o espaço urbano.

Em linhas gerais, os serviços têm como característica serem demandados pelo cliente, que espera obter do prestador, um determinado desempenho. O cliente vai buscar aquele que atende suas expectativas quanto a este desempenho, seja um serviço médico, de estética, ou de alimentação. Assim, ainda que a acessibilidade deva ser adequada ao meio de locomoção de seu público, não existe a obrigatoriedade de ser acessado diretamente da rua, podendo se situar em sobrelojas ou andares de uma torre comercial. Segundo Vargas (2015), é a qualidade do prestador de serviço que mantém seu fluxo, fidelizando o cliente.

Já o comércio se define pela oferta de produtos e mercadorias que podem ser oferecidas em diversos locais, portanto a questão da localização com o fluxo lhe é mais sensível do que no setor de serviços.

A grande diversidade das atividades de comércio e serviços na cidade contemporânea resulta numa enorme variação de necessidades locacionais e arquitetônicas, principalmente com o advento e crescimento do comércio eletrônico.

Os principais fatores que determinam as necessidade locacionais e arquitetônicas para o comércio e serviços envolvem os fluxos existentes de consumidores (faixas de renda, faixa etária, meios de transporte); frequência da compra (se diária, eventual ou esporádica); tipo de compra (planejada, comparada, por impulso ou conveniência ${ }^{36}$ ); o tipo de produto ou serviço ofertado (perecível, durável, de pequeno ou grande porte); motivação do consumidor (compras necessárias ou hedônicas); tipo de estabelecimento (loja de rua, loja em shoppingcenter, centro especializado ou rua especializada, franquia ou loja independente). Todas estas condicionantes interagem, ainda, com as condições pré-existentes nas cidades, relativas às condições de mobilidade (transportes, acessibilidade, capacidade do sistema viário); estrutura fundiária e padrão construtivo das edificações, usos (legais e informais) existentes e normas de uso e ocupação do solo. (VARGAS, 2015)

\footnotetext{
${ }^{36}$ Para saber mais sobre os tipos de compra ver: Nelson, (1958).
} 


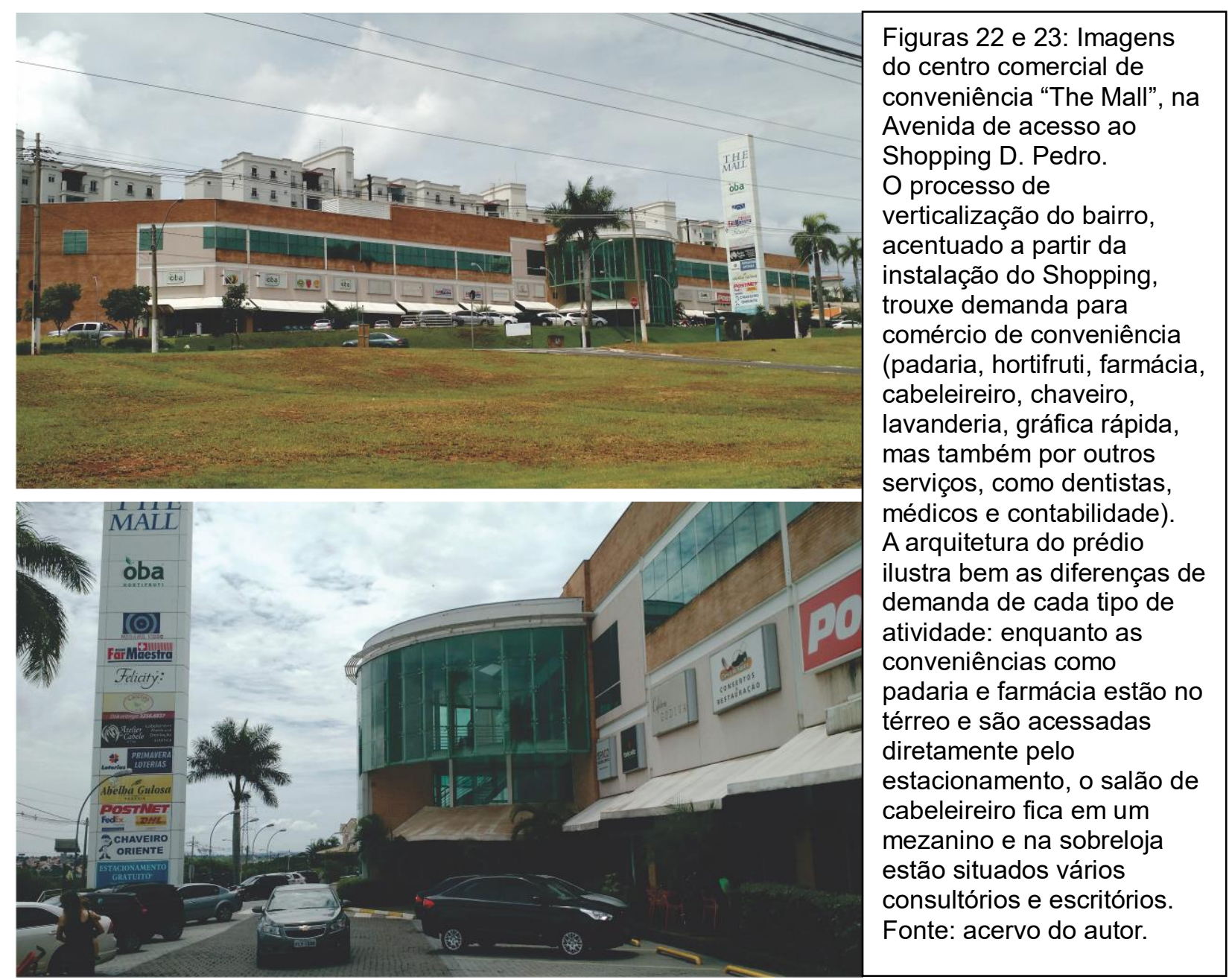

Desta maneira, uma determinada atividade pode, por exemplo, necessitar do fluxo de pedestres (compras por impulso) com a proximidade de vitrines das calçadas enquanto que para outra, as vagas de estacionamento são fundamentais. Mesmo entre tipos de atividades que demandam estacionamento, existem diferenças: enquanto que em alguns casos a localização destas vagas (se no térreo ou em subsolos) é indiferente, para compras rápidas e de conveniência (como padarias) é fundamental que as vagas estejam no nível do pavimento de acesso da loja, junto à edificação, facilitando a acessibilidade pelo consumidor e agilizando seu tempo, pois este tende a se tornar cada vez mais escasso (CACHINHO, 2008; VARGAS, 2014).

O tipo de compra esporádica (loja de colchões, ou artigos de noivas, por exemplo) permite uma maior flexibilidade na localização, por que o consumidor vai buscar o produto ou oferta específica para atender a uma necessidade também específica. Por outro lado, para as necessidades diárias a proximidade com a 
moradia ou trabalho é importante. Num fenômeno mais recente, decorrente das dificuldades de mobilidade urbana, ganha importância a acessibilidade durante o trajeto de retorno para casa. As compras para consumo diário, que normalmente eram feitas nas proximidades da residência, (como padarias e casas de carne) tendem, nas grandes cidades, a serem feitas durante o percurso de retorno ao lar, devido ao grande tempo em que se perde nos deslocamentos (Vargas, 2015).

Da mesma forma, alguns serviços em que era comum o consumidor se deslocar (serviços bancários, por exemplo), também procuram se aproximar do consumidor ou de seus trajetos diários. No caso dos bancos, na busca pelos clientes as agências diminuíram de tamanho (também graças aos avanços na tecnologia) e ganharam uma grande capilaridade, procurando se aproximar dos consumidores, evitando que ele tenha que se deslocar (Fig. 24).

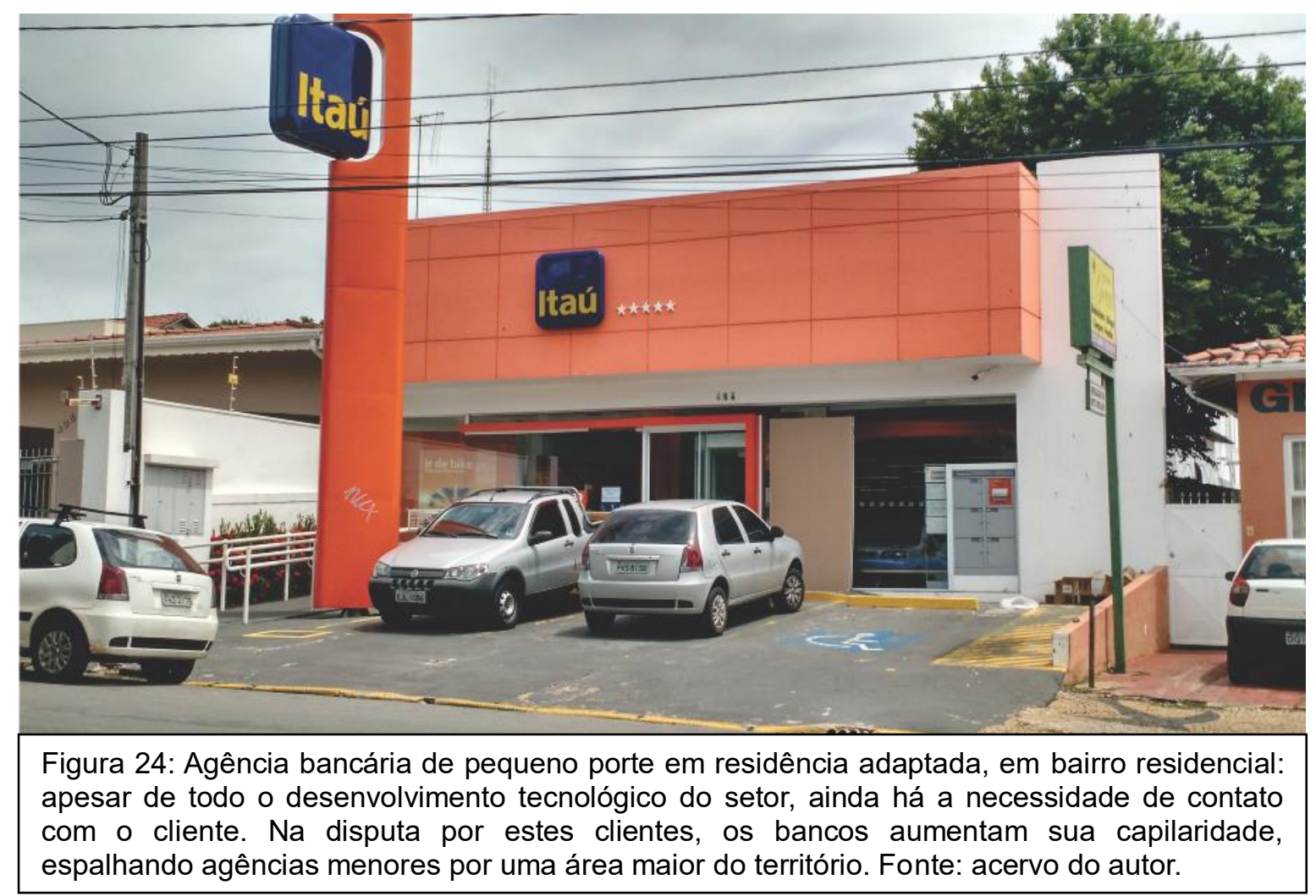

Devido à complexidade e à variedade dos fatores envolvidos, a questão da localização do terciário não nos parece um assunto que deva continuar a ser tratado nas legislações urbanísticas com os critérios usuais, isto é, baseando-se na separação de funções com zonas estanques, que nossos modelos de legislação consagraram de acordo com as influências do zoning norte-americano, como vimos anteriormente. Também não podem ser tratados com a complexidade marcada pelo 
tamanho dos empreendimentos isolados, ou seja, pela área construída. Em várias das legislações urbanas ainda existentes, o comércio e o serviço local eram definidos pelo tamanho do estabelecimento não podendo ultrapassar um limite. Só que a somatória de estabelecimentos concentrados, em alguns casos bem maiores do que alguns Shopping Centers, oferece intensidade de fluxos equivalentes ou superiores a estes, sem as devidas ações mitigadoras e compensatórias.

Nos últimos anos, temos observado uma preocupação dos planos diretores e outros diplomas legais ${ }^{37}$ em estabelecer uma relação entre as áreas passíveis de receber atividades terciárias e os eixos de transporte público, pois se infere que estes percursos teriam a capacidade de "atrair" o comércio e os serviços. Vargas (2015) coloca que, na verdade, o que serve de atração são os fluxos gerados em suas estações e terminais, e, eventualmente em algumas paradas, o que não se repete necessariamente ao longo de todo seu percurso. Uma decisão aparentemente muito mais simples, como a inversão de sentido de trânsito em uma determinada via, ou a execução de um corredor de ônibus, também pode agir negativamente, sobre todo seu entorno.

O caso da Avenida Santo Amaro em São Paulo é emblemático, pois após a execução do corredor de ônibus diminuiu muito a sua atratividade como localização comercial, além ter sofrido uma grande degradação nas suas qualidades urbanas e ambientais $^{38}$. A obrigatoriedade ou incentivo aos usos comerciais e de serviços, nos andares térreos, em torres residenciais ou de serviços, ao longo destes eixos, não garante sua viabilidade, trazendo, na verdade, o risco de uma série de espaços desocupados no futuro, por excesso de oferta.

As tentativas de se instituir o terciário "por decreto", e que não levam em consideração estas dinâmicas urbanas e as especificidades do setor terciário, muito

\footnotetext{
${ }^{37}$ A ligação entre a obrigatoriedade de adoção de atividades terciárias, (como as chamadas fachadas ativas em empreendimentos residenciais) pode variar de localidade para localidade, sendo definida por normas legais de diversos níveis hierárquicos, não necessariamente no Plano Diretor, podendo por exemplo, estar prevista numa lei de operação urbana consorciada, ou mesmo na lei de uso e ocupação do solo.

${ }^{38} \mathrm{Na}$ coluna de Leão Serva, na Folha de São Paulo, de 10/03/2014, o jornalista, conhecido defensor do transporte público, ilustra as dificuldades da Prefeitura de São Paulo nos debates sobre a implantação de corredores de ônibus, com a oposição de comerciantes e moradores que não se cansam de lembrar o caso da Santo Amaro: "[...] Outros disseram que o corredor de onibus vai degradar a Sabará como fez com a av. Santo Amaro. Até os anos 1980 essa via tinha trânsito equilibrado, um comércio vigoroso que convivia bem com prédios residenciais. Quando começou a ocupação desordenada das áreas de manancial na Zona Sul (Parelheiros, Jardim Ângela, Capela, Pedreira etc), o trânsito em direção ao Centro começou a se adensar. O prefeito Mario Covas (1983-85) decidiu implantar ali um corredor de ônibus. Em pouco tempo o comércio estava arrasado e a avenida sofreu um degradação ambiental vertiginosa. Até hoje a Santo Amaro não se recuperou e está ai para justificar a reação do pessoal da Sabará”.
} 
provavelmente redundarão em fracasso, como no caso de Curitiba, onde se tentou criar este tipo de ocupação mista com térreos comerciais em vias de fluxo rápido. (VARGAS, 2015 p.3)

Para que o terciário se viabilize é necessário que os diversos fatores que comentamos, estejam em sintonia com as condições de fluxo e renda.

Apesar de ficar claro que o modelo de zoneamento monofuncional não responde mais às necessidades da vida contemporânea, há uma grande resistência, especialmente nos enclaves de classes mais altas, à presença das atividades terciárias.

De certa maneira a questão da incomodidade de alguns usos terciários acaba por dificultar que as legislações sejam mais permeáveis a modelos que contemplem múltiplos usos.

Nos Estados Unidos, por exemplo, o Congress of New Urbanism ${ }^{39}$, defende este tipo de abordagem como melhor caminho para combater os problemas decorrentes do processo de suburbanização, como a dispersão urbana, os congestionamentos de tráfego e a dependência do transporte individual, reaproximando a moradia, o trabalho e o consumo.

Entre os modelos propostos estão os "Form Based Codes", termo que se aplica a legislações que estão mais preocupadas com a escala e densidade das edificações e populações, do que com a segregação de usos, exceto aqueles notoriamente nocivos ou incômodos. (Duany; Platter-Zyberk; Speck, 2000; Hirt, 2014).

É previsível que determinados usos apresentem incompatibilidade com áreas predominantemente residenciais, como bares e casas noturnas (grandes geradores de conflito, vide casos como o bairro do Cambuí em Campinas), ou mesmo

\footnotetext{
39 O primeiro "Congress for the New Urbanism" ocorreu em 1993 e a partir da publicação de sua carta de princípios em 1996, se tornou uma organização permanente, não lucrativa. Segundo sua carta de princípios, "O Congresso para o Novo Urbanismo vê o desinvestimento nos centros urbanos, a proliferação de expansões urbanas sem sentido, o aumento da segregação por raça ou nivel de rendimento, a degradação ambiental, a perda de solos agrícolas e espaços naturais e a erosão do património edificado como um único desafio para o futuro das comunidades.[...]os bairros devem ser diversificados nos usos e na população; as comunidades devem ser concebidas tanto para o trânsito de peões como de automóveis; as cidades e vilas devem ser configuradas por espaços públicos fisicamente definidos e, como os edifícios públicos, universalmente acessiveis; a concepção da arquitectura e da paisagem que enforma os lugares urbanos deve consagrar a história, o clima, a ecologia e as práticas construtivas locais" Fonte: sítio do CNU https://www.cnu.org/sites/default/files/cnucharter_portuguese.pdf
} 
estabelecimentos que necessitem receber mercadorias no período noturno, já que a maioria dos veículos de carga gera ruídos em níveis incompatíveis com o sossego dos moradores.

Como já citado no cap.1, a segregação de usos incômodos ou perigosos não é algo recente. A grande inovação surgida com o advento do zoning foi a criação de áreas exclusivamente residenciais, como as Z-1 de São Paulo (atualmente ZERs) ou a Z-3 protegida, Z-4 e Z-8 em Campinas, como veremos mais adiante. Sobre estes casos, especialmente no que diz respeito à Campinas, podemos dizer que, do mesmo modo que não se criam áreas para o terciário por decreto, também a legislação não é capaz de impedir, per si, que as dinâmicas urbanas variadas propiciem seu florescimento, ainda que, muitas vezes, em desacordo com esta mesma legislação, o que será detalhado nos capítulos 3 e 4 para o caso de Campinas.

A questão da localização envolve inicialmente duas premissas de análise opostas, ainda que baseadas nos mesmos dados. Pode-se olhar sob a ótica da empresa de um determinado ramo de atividade que busca a localização mais vantajosa para se instalar, ou então, trilhando-se o caminho oposto, escolher qual a atividade mais adequada para se instalar em uma determinada localização.

Conforme Vargas (2001) coloca, as escolhas que envolvem a localização do comércio e serviços varejistas baseiam-se na busca da relação mais vantajosa entre receitas e custos, maximizando-se a diferença entre eles. A capacidade de se auferir receitas está diretamente ligada à renda e à quantidade dos consumidores, ou seja, densidade demográfica e renda.

No entanto, diante do desenvolvimento das novas tecnologias de informação e comunicação, o fator locacional também tem assumido outras características, assim como impactado na forma de atuação das empresas. Vargas (2001, p.79) cita o setor de agências e operadoras de turismo como um dos setores mais atingidos, uma vez que grande parte dos serviços que essas empresas prestavam, pode ser obtido virtualmente. Outro setor fortemente impactado pelo desenvolvimento tecnológico foi o das vídeolocadoras, hoje quase desaparecidas com a disseminação dos serviços de streaming.

As vendas virtuais (telemarketing e internet) tem adquirido uma importância 
crescente, porém Vargas (2001, p.80) afirma que:

“... na maior parte das atividades terciárias- comércio e serviços, recreação e lazer, educação e saúde, turismo, etc. - a necessidade de interação social vai continuar presente. O comércio, principalmente, como se terá a oportunidade de verificar, não pode prescindir do encontro de fluxos de pessoas, mercadorias e serviços, ainda que o encontro virtual esteja cada vez mais presente."

Entretanto, há uma série de fatores que vão desde culturais (em especial do pequeno comerciante ou prestador de serviços e mesmo dos trabalhadores) ou mesmo de restrições no espaço físico que geram resistência às mudanças, ressaltando que a tecnologia não age por si mesma. $O$ embate atual, entre os aplicativos de compartilhamento de caronas (como o Über) e os motoristas de táxi é apenas mais um exemplo.

A disseminação dos processos e equipamentos, que atinge hoje até as vendas de bairro, permite um melhor controle de estoque, das vendas e da distribuição. Por outro lado, como já citado no caso das agências bancárias, a miniaturização dos equipamentos e a oferta de muitos serviços por via virtual, sem a necessidade do encontro físico, permitiu uma diminuição dos espaços físicos, ou no caso do comércio a realocação de estoques em galpões centralizados.

A necessidade de fluxos de consumidores, mercadorias ou veículos, demandada pelo setor terciário, virtuais ou presenciais, definem suas possibilidades de localização. É esta compreensão da complexidade do terciário, aqui apresentada, que direciona nossa análise sobre o território da cidade de Campinas, fundamentalmente voltada para a elaboração de políticas públicas. Estas políticas podem ser intervenções de ordem macroeconômicas e microeconômicas, que por sua vez, podem agir positivamente ou negativamente, em uma determinada localização.

O modelo de legislação de Uso e Ocupação do Solo, fundado no zoneamento monofuncional e na proteção às áreas de alta renda, e suas dificuldades em lidar com uma cidade (e sociedade) em transformação acelerada, que abordaremos mais detidamente nos Capítulos 3 e 4, é um dos principais pontos em que as políticas públicas se chocam com as dinâmicas próprias do setor terciário. 


\section{CAPÍTULO 3}

\section{1 - Campinas, a Lei de Uso e Ocupação, e o setor terciário.}

Campinas na década de 1880 era o centro da economia cafeeira do Império (as lavouras do Vale do Paraíba haviam entrado em franco declínio), e por volta de 1888 contava com 20.000 habitantes na zona urbana e cerca de 50.000 em todo o município (BERGÓ, 1944 ${ }^{40}$ apud BADARÓ, 1996).

A partir de 1889, porém, surtos consecutivos de febre amarela instauraram uma situação de calamidade na cidade que viu sua população decrescer para cerca de 5.000 habitantes com a transferência de moradores e recursos econômicos para outras áreas do interior e para a capital da província, num verdadeiro êxodo econômico e social.

A retomada das obras de infraestrutura, com foco no saneamento, ocorre a partir de 1891 e em 1895 a Lei n43 estabelece normas de "hygiene e solidez" (recuos, afastamentos, iluminação, ventilação e materiais de revestimento) para as edificações dentro do perímetro urbano, se configurando como o primeiro Código de Edificações da cidade(BADARÓ, 1996; BERNARDO, 2002).

Os esforços municipais e do governo estadual que instalou em Campinas o Centro de Comissão Sanitária do Estado, possibilitou que sob a orientação do Eng. ${ }^{\circ}$ Saturnino de Brito se drenassem charcos, melhorasse a captação e tratamento de águas e canalizassem alguns córregos o que possibilitou a abertura de algumas avenidas em fundos de vale, antes alagadiços (BADARÓ, 1996).

Em 1897 se encerra a crise da febre amarela e em 1900 a população urbana retorna ao patamar de 19.000 habitantes. A economia da cidade começa a se diversificar com a instalação de indústrias (tecelagem, implementos, cervejaria e mecânica com as oficinas da Cia. Mogiana produzindo inclusive locomotivas).

A posição estratégica como maior entroncamento ferroviário do país e o acesso para todo o interior do estado e sul de Minas começam a criar um polo de comércio e serviços com alcance regional. A população chega a 50.000 habitantes já

\footnotetext{
${ }^{40}$ BERGÓ, M. E. de A. Estudo geográfico da cidade de Campinas, In: Anais do X Congresso Brasileiro de Geografia, Rio de Janeiro, volume III, 1944
} 
em 1920.

A maior parte deste contingente ocupa o perímetro urbano original que havia sido esvaziado pela epidemia e posteriormente reurbanizado.

Semeghini (2006) considera a urbanização e o desenvolvimento de Campinas como exemplo do modelo resultante da economia baseada no café. Segundo o autor, esta base econômica permitiu a adaptação dos processos produtivos em consonância com as diferentes etapas do desenvolvimento capitalista no Brasil.

O autor observa, porém, que no caso de Campinas há uma diversificação das atividades produtivas advinda de sua posição estratégica no território paulista, se tornando desde muito cedo uma centralidade. Como maior entroncamento ferroviário do interior do país (Paulista, Mogiana, Sorocabana e Funilense) escoava não apenas sua própria produção cafeeira, como também intermediava o escoamento de grande parte da produção oriunda de outras regiões em direção ao porto de Santos.

Entre 1920 e 1940 o acúmulo de capitais e a boa infraestrutura com a cidade, saneada e recuperada dos efeitos das epidemias de febre amarela ${ }^{41}$ do final do séc. XIX, a cidade assume a condição de principal polo industrial do interior paulista saltando de 9,7\% para 11,2\% (NEGRI, 1996 ${ }^{42}$, apud SILVA, 2008) do número de operários na indústria de transformação no Estado e São Paulo, superando Sorocaba que era a maior do interior até então.

Segundo Badaró (1996 p.36), em meados dos anos 20 ocorreu uma intensificação do processo de urbanização com a expansão da área urbana edificável e uma valorização dos terrenos. Há um aumento da demanda por habitação decorrente da industrialização crescente. Como a demanda é maior por lotes mais baratos, começam a ocorrer parcelamentos desconectados da mancha urbana original.

A partir de 1922 e até os princípios da década de 30, vários loteamentos foram implantados (São Bernardo, Vila Marieta, Jd. Guanabara, Parque Industrial

\footnotetext{
${ }^{41}$ Entre 1889 e 1897 surtos consecutivos de febre amarela causaram muitas mortes e o consequente êxodo de moradores foi enorme: de 41.253 hab. em 1887 a população decai a cerca de 5.00hab. no ápice da epidemia. A partir de 1896 um plano elaborado pelo Eng. ${ }^{\circ}$ Saturnino de Brito saneia a cidade que logo se recupera atingindo 67.694hab. em 1900, com um grande contingente de imigrantes, com cerca de 20.000 pessoas (SEMEGHINI, 1988)

${ }^{42}$ NEGRI, Barjas. Concentração e desconcentração industrial em São Paulo (1880-1990). Campinas: editora da UNICAMP, 1996.
} 
entre outros bairros surgiram), não mais pela prefeitura: o capital imobiliário especulativo passa a protagonizar o desenho da cidade.

A maioria destes loteamentos nasce desta forma desconectada do reticulado original, e sem critérios técnicos de planejamento, criando inclusive problemas de conexão viária além de colocar novos desafios ao sistema de abastecimento de águas e ao saneamento. A figura do lote isolado, com a residência unifamiliar vai se tornar neste momento, o modelo a partir do qual se constrói o desenho da cidade (BADARÓ, 1996; ROSSETO, 2006).

A crise de 1929 atinge fortemente a produção cafeeira propiciando uma mudança na base econômica do país, com o redirecionamento da destinação de capitais para a implantação da primeira fase de industrialização do Brasil, com a produção de bens de consumo não duráveis.

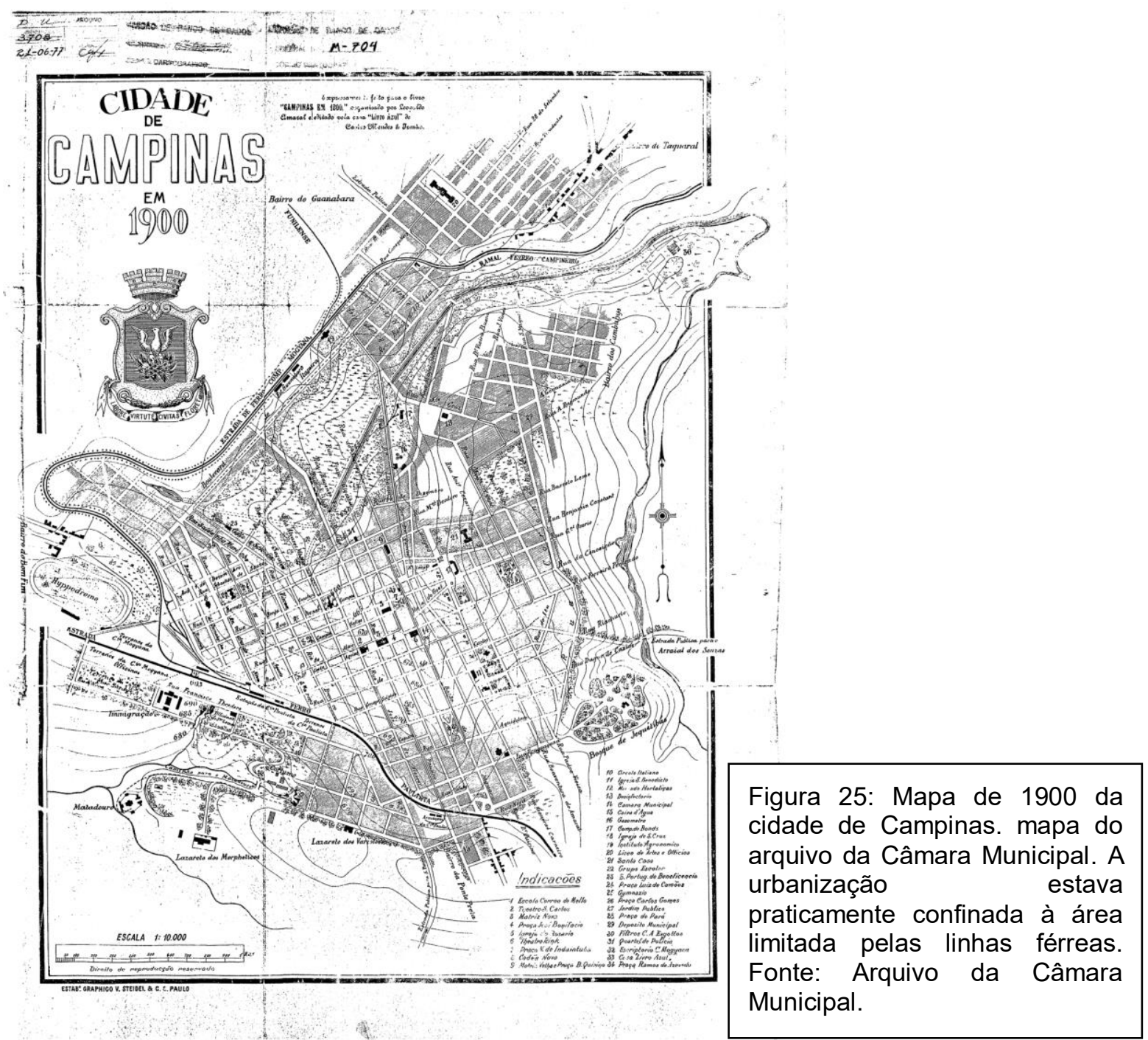




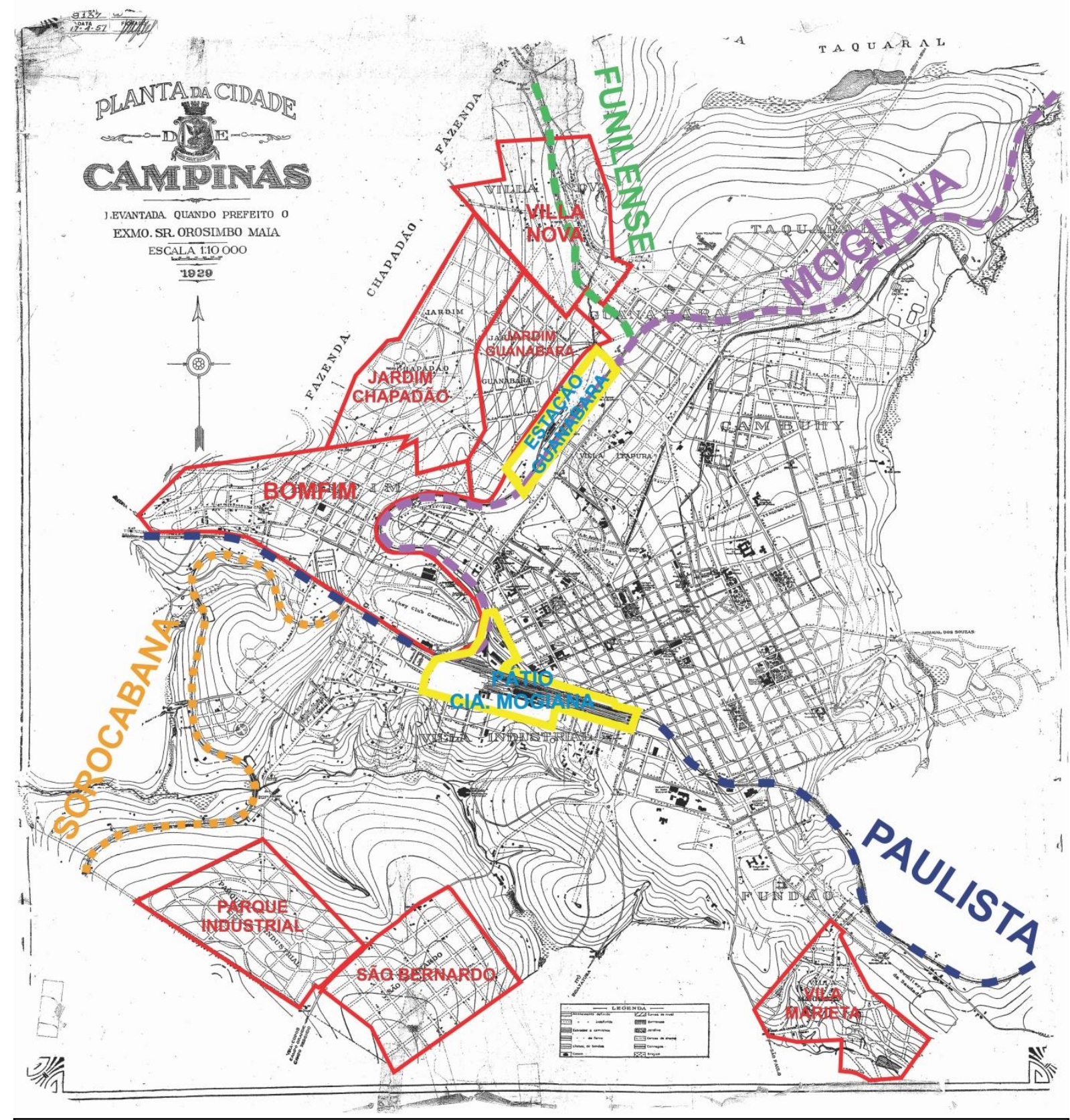

Figura 26: Mapa de 1929 da cidade de Campinas. Planta cadastral elaborada por Jorge Macedo Vieira, por solicitação do Prefeito Orosimbo Maia, com vistas a contratação de Anhaia Mello para a elaboração de um Plano Geral. O levantamento viria a servir de base para o Plano de Melhoramentos Urbanos que seria elaborado por Prestes Maia, no final dos anos 30. No mapa de 1929 já se observa a expansão dos novos loteamentos, inclusive por sobre os ramais das ferrovias. Assinalados em vermelho estão bairros que viriam a se tornar importantes, como o Bomfim, o Jd. Guanabara, o Jd. Chapadão, a Villa Nova e a Vila Marieta (Fundão). No quadrante sudoeste já se observa dois bairros desconectados do perímetro original e que rompem o modelo de crescimento em franjas concêntricas, que são o São Bernardo e o Parque Industrial, num padrão que se intensificaria nos dez anos do pós-guerra (1946-1955). Fontes: BADARÓ (1994), BERNARDO (2002) e SILVA (2008). Fonte: A partir de mapas do arquivo da Câmara Municipal, com anotações nossas. 
Em uma cidade que havia quase desaparecido devido à epidemia e que havia se reerguido com muito esforço e investimento, esta expansão urbana desordenada, fruto da recuperação econômica e do desenvolvimento industrial, gerou preocupação nos círculos da elite campineira, antenada com as discussões sobre urbanismo, e buscando uma imagem de grande, moderna e próspera cidade. (BADARÓ, 1996 p.37-38)

Em 1929 foi encaminhado à Câmara Municipal pelo então Prefeito Orosimbo Maia um memorando sugerindo a conveniência de se elaborar um plano de urbanismo para a cidade. A planta cadastral da cidade (fig. 25) foi elaborada para servir de base aos estudos e foi feito contato com o Eng. ${ }^{\circ}$ Anhaia Mello que chegou a apresentar proposta para um "Master Plan". A crise de 1929 e as revoluções de 1930 e 1932 adiaram as discussões sobre o assunto que foi retomado a partir de 1933 e culminou na contratação de Prestes Maia em 1934 para a elaboração de um Plano de Urbanismo para Campinas (BADARÓ, 1996).

As propostas de Prestes Maia resultaram no Plano de Melhoramentos Urbanos, promulgado em 23/04/1938 através do Ato Municipal n¹18.

No que diz respeito ao uso e ocupação do solo, o Plano de Melhoramentos não introduzia o zoneamento, do qual tratava em termos muito vagos. Mas a proposta original de Prestes Maia, constante de seu relatório, trazia uma visão a respeito do território do comércio na cidade, que consideramos como inovadora (para a época).

Segundo esta proposta, o comércio ficaria disposto ao longo das vias radiais e perimetrais, na periferia das unidades residenciais. Para Badaró (1996) a ideia de malha viária principal com função comercial definindo em seu interior áreas residenciais, intencionava conferir ao zoneamento um caráter de permanência, que dispensasse frequentes alterações: "A cidade cresceria... por constituição de novas unidades e não por transformação contínua das zonas commerciais ou mais densas" (MAIA, 1938 p. 82 apud BADARÓ, 1996 p.78).

Estas unidades residenciais seriam segundo Prestes Maia semelhantes às cidades-jardim inglesas: "A diferença consiste em terem zona residencial no centro $e$ commercial no perímetro, ao passo que nas cidades-jardim verifica-se o contrário” (Ibidem, p.83). 
A singularidade desta proposta reside no fato de que ao procurar evitar a expansão do centro sobre as zonas residenciais consolidadas de certo modo contrariava a rígida subdivisão da cidade em zonas estanques e diferenciadas, permitindo que o terciário se escoasse através das radiais e perimetrais, envolvendo as áreas residenciais sem se sobrepor a elas (ao contrário do modelo usual de zoneamento que confinava as áreas comerciais centrais dentro de um anel exclusivamente residencial).

Em 1934, foi aprovado o Código de Construções que divide a cidade em 4 zonas concêntricas, regulamentava condições para construções e arruamentos e define o perímetro dos Distritos (Arraial dos Souzas, Joaquim Egídio, Cosmópolis, José Paulino, Rebouças e Valinhos). Numa tentativa inicial de controle dos usos os usos insalubres ou perigosos são restritos à $4^{\mathrm{a}}$ zona.

Este Decreto não traz nenhuma restrição ao loteamento de áreas rurais que, após serem loteadas, são incorporadas à área urbana. Suas disposições permitiam que imóveis da $4^{\mathrm{a}}$ zona e mesmo da área rural passem automaticamente para a $3^{\mathrm{a}}$ zona quando vendidos, possibilitando a urbanização de áreas rurais e potencializando a expansão horizontal da cidade, a partir dos eixos das estradas rurais.

O Código de Construções Municipal estabeleceu os parâmetros mínimos para construções, arruamentos e divisão de terreno em lotes em Campinas. Segundo Santos, A.(2002) ele exigia a obrigatoriedade de licença da municipalidade para a abertura de vias e a divisão de terrenos em lotes.

O proprietário deveria apresentar a planta dos terrenos a arruar para apreciação da Repartição de Obras e Viação e se o projeto for considerado adequado eram traçadas pela municipalidade as vias principais e demais espações de interesse da municipalidade.

Finda a guerra, ocorreu uma intensificação na abertura de novos loteamentos em Campinas: Badaró $^{43}(1996$, p.121) demonstra que no período de 1945 a 1952 a área urbana parcelada do município triplicou. Contribuiu muito para esta explosão no número de loteamentos, a facilidade de abertura de novos arruamentos devido à

\footnotetext{
${ }^{43}$ Segundo autor, a soma dos lotes edificáveis em Campinas, por volta de 1953, tinha capacidade para abrigar uma população de cerca de 400.000 hab., ou seja, três vezes a população da cidade à época.
} 
permissividade da legislação que pouco exigia do loteador em relação a melhoramentos públicos e infraestrutura.

\begin{tabular}{cc}
\hline Tabela 1 - Loteamentos aprovados por década em Campinas \\
\hline Década & Loteamentos aprovados \\
\hline 1920 & 24 \\
1930 & 42 \\
1940 & 81 \\
1950 & 322 \\
1960 & 66 \\
1970 & 70 \\
1980 & 121 \\
1990 & 60 \\
2000 & 32 \\
2010 & 18 \\
\hline
\end{tabular}

Fontes: PMC/SEPLAN apud SILVA, 2008, p.60 (1920-1999) e PMC/SEMURB, 2015 (2000-2014).

Esta permissividade deixava a porta aberta para a expansão indiscriminada de loteamentos que ocorreria no pós-guerra. $\mathrm{O}$ autor demonstra que a produção de lotes em escala muito superior à capacidade de absorção pelo mercado geraria um desequilíbrio, que somado às novas exigências legais de infraestrutura (que entrariam em vigor na segunda metade daquela década), acabaram por arrefecer este boom especulativo, com os capitais se redirecionando à incorporação e construção de edifícios, acelerando a verticalização da área central, que se iniciara lentamente a partir dos anos 40 (Ibidem, p.122).

Bernardo (2002) demonstra que este período viu um enorme incremento da mancha urbana com a adição $217 \%$ de área no período de $1940-52$ e mais um incremento de $93 \%$ no decênio seguinte. 


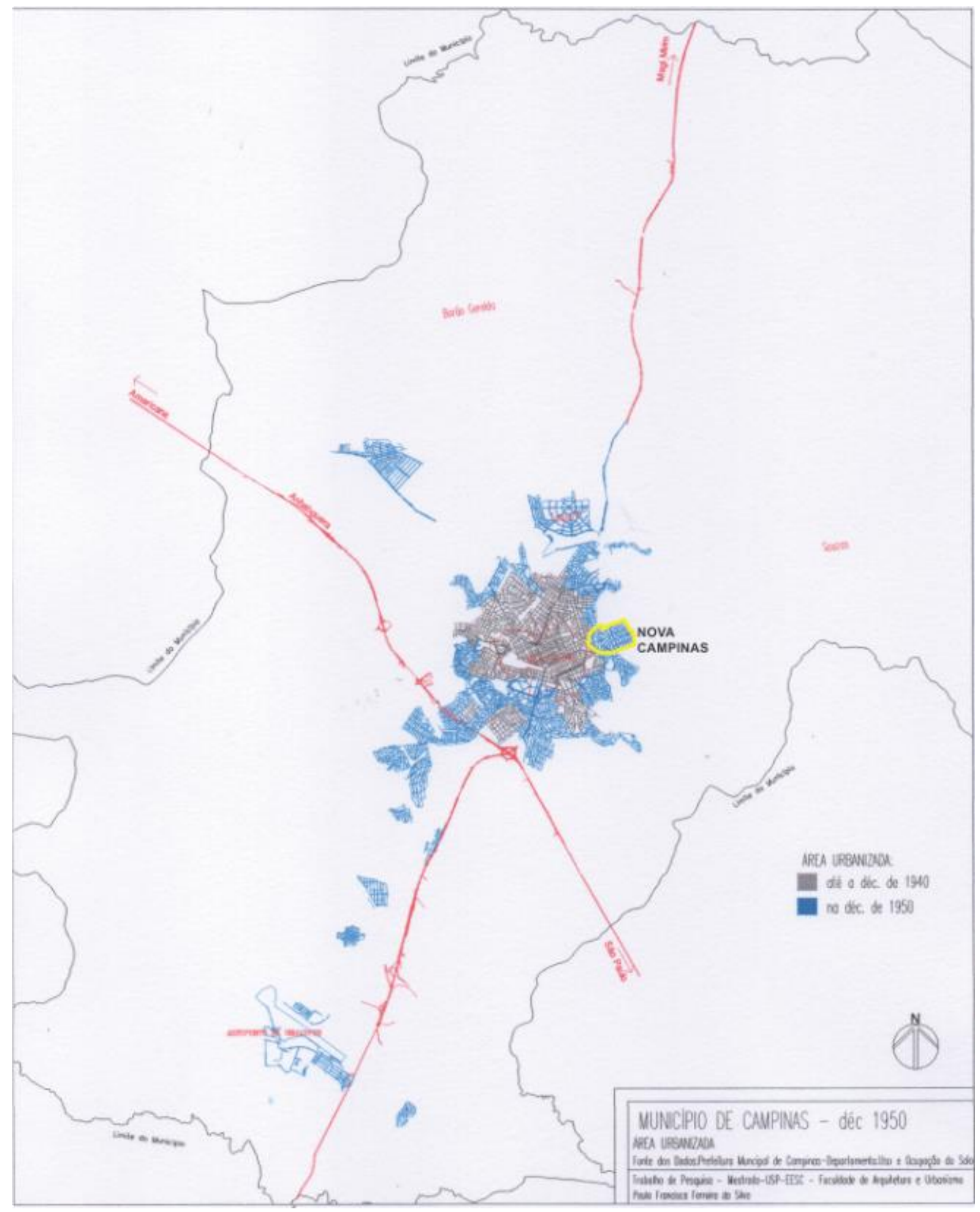

Figura 27. Área urbanizada de Campinas até 1950. Fonte: a partir de SILVA (2008). O Bairro Nova Campinas, objeto do Cap. 4, foi destacado em amarelo. No extremo sudoeste já se vê urbanização em torno do Aeroporto de Viracopos 

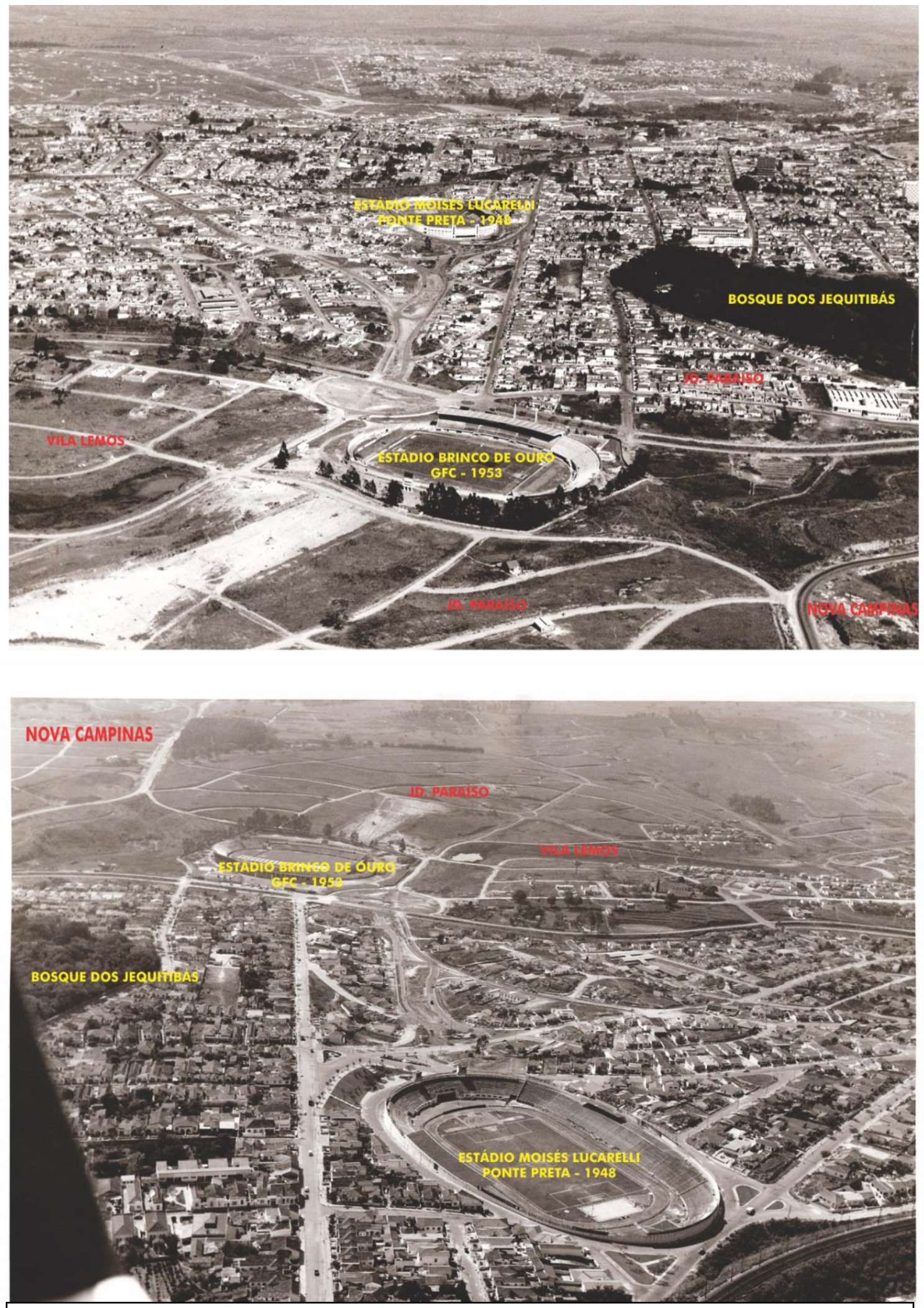

Figuras 28 e 29: Imagens aéreas de meados da década de 1950, com visadas praticamente opostas. Identificamos alguns dos novos loteamentos, que ainda estão esparsamente ocupados. Os créditos e a data exata não estão indicados, mas é possível estimar o período pelos estádios da Ponte Preta e do Guarani, cujas datas de inauguração são conhecidas. A Nova Campinas aparece no canto inferior direito na $1^{\mathrm{a}}$ imagem e no canto superior esquerdo na $2^{\mathrm{a}}$. Fonte: a partir de imagens do acervo do Centro de Memória I UNICAMP. 
Esta situação começaria a mudar em fins da década de 1950: a partir de 1957 exige-se do loteador os custos da implantação da rede de distribuição de água e, em 1959, foi promulgado o Código de Obras Edificações através da Lei 1993/195944, que incluía um capítulo sobre loteamentos:

Capitulo 7.2.2 - Condições mínimas que devem satisfazer as glebas a arruar e lotear

Art. 7.2.2.01 - Os arruamentos residenciais, constituídos por glebas inscritas pelos perimetros urbanos ou suburbanos para que possam ser aprovados deverão satisfazer, preliminarmente, às condições seguintes:

a) ter ligação à via pública oficial;

b) oferecer condições topográficas tais que permitam a sua ligação às redes de águas e esgotos existentes ou planejadas;

c) obedecer a um traçado de ruas que permita escoamento das águas pluviais pelas galerias e vias públicas existentes, no caso delas não escoarem diretamente pelos escoadores naturais da cidade;

d) obedecer aos traçados da Prefeitura em relação às reservas de áreas para construção de escolas primárias, profissionais e secundárias, e de áreas para logradouros públicos, parques infantis e teatros ao ar livre, de acordo com o plano de urbanização da região.

d) obedecer aos traçados da Prefeitura em relação às reservas de áreas para construção de obras e edifícios de interesse público, instituições a critério da Prefeitura, áreas de logradouros públicos, de acordo com o plano de urbanização da região;

e) obedecer os traçados da Prefeitura em relação às reservas de áreas para a construção de futuras estações parciais ou regionais para depuração de esgotos, de tratamento ou distribuição de água de acordo com o planejamento geral do município;

f) obedecer aos traçados impostos pela Prefeitura que objetivem as reservas de áreas para efetuação do represamento de águas que formem açudes, lagos ou tanques necessários ao abastecimento de água da região

\footnotetext{
${ }^{44} \mathrm{O}$ capítulo que trata do parcelamento do solo nesta lei permanece em vigor até hoje, balizando a aprovação de todos os loteamentos no município de Campinas.
} 
ou criação de centros recreativos e esportivos planejados para a zona;

g) obedecer aos traçados da Prefeitura que visem salvaguardar áreas florestadas ou incluidas no plano de reflorestamento do município. Parágrafo único - As áreas reservadas para atender os objetivos constantes da letra " $d "$ deste artigo não poderão exceder a $5 \%$ (cinco por cento) da declividade e deverão se situar em local de livre acesso e que facilite os futuros frequentadores. (acrescido pela Lei $n^{\circ} 4.606$, de 19/05/1976);

Fonte: Biblioteca Jurídica da P.M.C.

Outros fatores que contribuíram para a expansão dos loteamentos foram a necessidade de destinação para os capitais acumulados com a exportação de commodities e a consolidação, iniciada na década de 1920, do modelo de residência isolada no lote como o principal componente do ambiente urbano na cidade.

Rosseto (2006) explica como esta tipologia passa, nas primeiras décadas do Séc. XX, a ser predominante na expansão da cidade com a abertura de novos loteamentos que por sua vez desenham um novo modelo de cidade, de bairros residenciais gravitando ao redor de uma centralidade de múltiplos usos (a área da cidade antiga).

Melo (1992 $2^{45}$, apud Feldman 1996, p.16), coloca que entre 1941 e 1946 a atividade imobiliária se intensifica no Brasil como campo de investimento dos lucros advindos da expansão industrial, do comércio e da exportação agrícola.

As décadas de 1940 e 1950 viram um crescimento acelerado da população, com várias indústrias, inclusive multinacionais se instalando na cidade (Bosch, GE, Bendix, Clark, Merck, Dunlop, entre outras). A política desenvolvimentista do período (especialmente do governo Kubitscheck a partir de 1956, com a implantação da indústria automobilística), e a localização estratégica como entroncamento rodoferroviário (a Via anhanguera ligando de forma rápida a cidade à capital Paulista é inaugurada em 1948 e se torna a primeira rodovia com pista dupla do país em 1953), serviram de atratores para a industrialização e resultaram em grandes fluxos migratórios (FUPAM, 2015).

\footnotetext{
${ }^{45}$ MELO, M. A.de. O Estado, o boom do século e a crise de habitação: Rio de Janeiro e Recife (1937-1946). In: FERNANDES, A.F. \& FILGUEIRAS GOMES, M.A. (orgs.). Cidade \& História, Salvador, UFBA/Anpur, 1992.
} 


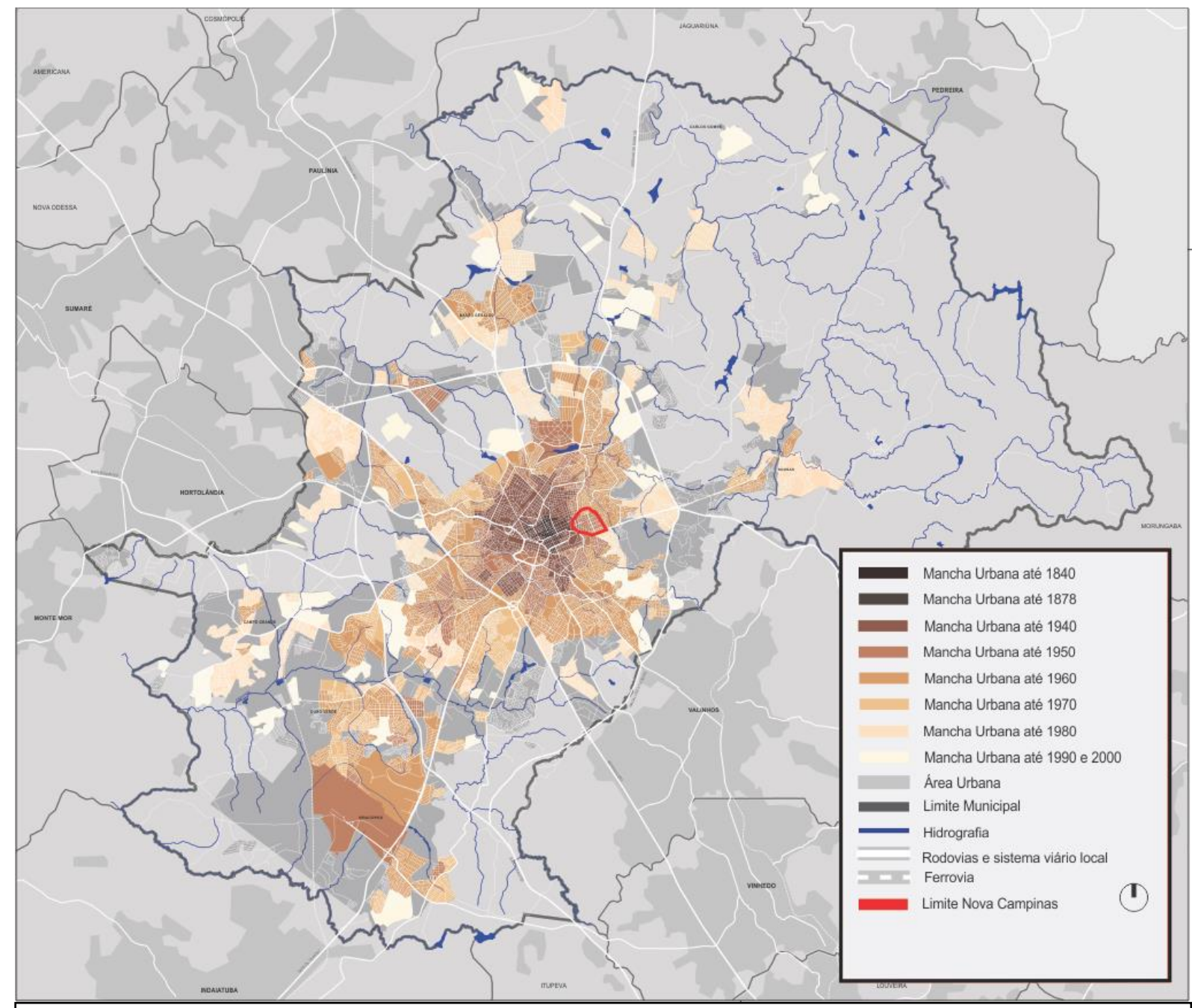

Figura 30: Mapa da evolução da mancha urbana no Município de Campinas. Neste mapa elaborado pela FUPAM, para o diagnóstico técnico, visando à atualização da legislação urbanística de Campinas, podemos acompanhar a evolução da mancha urbana sobre uma base com o sistema viário atual. Acrescentamos, em vermelho, a área da Nova Campinas. É interessante notar o grande incremento na área urbanizada, entre as décadas de 1940 e1970. Fonte: a partir de PMC, apud SILVA 2008 (período 1949-2000). Elaboração e demais dados: FUPAM (2015).

Fundado na década de 1930 e com utilização crescente a partir dos anos 50, o aeroporto de Viracopos em 1960 passa a ser homologado para operações internacionais e também é um fator de atração considerável.

Este aumento da mancha urbana, de certa maneira, pré-configura o padrão de dispersão urbana que se aceleraria muito a partir dos anos 70 e 80 , com sucessivas extensões no perímetro urbano.

Em 1951 é promulgada a Lei n640 que dá nova dinâmica à implantação do Plano de Melhoramentos Urbanos de 1938, autorizando desapropriações para a 
implantação daquele plano, mas também prevê novos parques públicos (como o Parque Taquaral) e áreas para edifícios e serviços públicos como o novo Paço Municipal, hospital municipal, matadouro, cemitério e escolas.

Quanto ao zoneamento, a Lei $n^{\circ} 640 / 51$ reafirma a intenção expressa originalmente no Plano de Melhoramentos Urbanos de o poder público ir gradativamente estabelecendo o zoneamento na cidade (Art. $8^{\circ}$ ), e, ao contrário do Ato $\mathrm{n}^{0} 118$ que não incorporou a questão do zoneamento, já se adianta (pelo menos em relação à área mais central), dividindo-a em 8 zonas onde estabelece parâmetros construtivos, (indo ao detalhe de especificar materiais de acabamento para as fachadas das lojas) recuos, alturas (aqui uma peculiaridade: estabelece em algumas áreas alturas mínimas e não máximas, como a reforçar o anseio pela verticalização como expressão de modernidade) e definindo alguns critérios em relação aos usos permitidos:

A área central é dividida em 3 Zonas, C1, C2 e C3, sendo que C1 e C2 está destinada basicamente ao comércio varejista (serviços estão inclusos), além de permitir as ocupações residenciais:

Art. $8^{o}$ - A Prefeitura providenciará, por meio de leis especiais, o zoneamento sistemático e gradual da cidade e dos distritos.

Art. $9^{\circ}$ - Enquanto não se concretizarem as medidas previstas no artigo anterior ficam constituidas as seguintes zonas: [...].

[...] Art. 11 - Nas Zonas C.1 e C.2 serão observadas, na aprovação de novas construções, além das exigências previstas em leis e regulamentos, mais as seguintes:

a) QUANTO AO USO

1) As lojas serão destinadas ao comércio varejista, ficando, os estabelecimentos que nelas se instalarem obrigados a apresentar aspecto condigno com a natureza da rua, sendo vedado os que se destinam ao comércio de materiais ou objetos apresentados de forma grosseira, mesquinha ou depreciativa para o local...

2) Os andares superiores poderão ser utilizados para escritórios, consultórios, etc. ou apartamentos residenciais. 
Já para a Zona C3 são as seguintes as permissões de usos:

Art. 12 - Na Zona C.3, serão observadas, na aprovação de novas construções, além das exigências previstas em leis e regulamentos, mais as seguintes:

a) QUANTO AO USO:

1) Além das utilizações permitidas em C.1 e C.2, os prédios construídos nesta zona poderão destinar-se ao comércio atacadista, cinemas, clubes, hotéis, garagens ou postos de gasolina a juízo da Prefeitura;

2) Poderão, também, ser destinadas a pequenas indústrias ou oficinas, que não produzam ruídos, cheiro ou poeiras nocivas à vizinhança [...].

Fonte: Biblioteca Jurídica da P.M.C.

A Lei $n^{\circ} 640$, porém, não é propriamente uma Lei de zoneamento (no caráter compreensivo, pois ignora a maior parte do território do município, exceto quanto à área central) e cumpre, em primeiro lugar, a função de operacionalização do Plano de Melhoramentos Urbanos, principalmente quanto à abertura de vias e desapropriações.

A obsolescência da legislação diante das mudanças econômicas e sociais da cidade, a dificuldade em atualizá-la e a susceptibilidade a intervenções pontuais e subjetivas já é apontada em reportagens da época como um dos motivos para revisão da legislação:

\footnotetext{
“... os departamentos da Prefeitura ficaram sem normas certas para firmar obrigatoriedades e proibições. E estas passaram a se subordinar ao critério dos Chefes do Executivo, resultando dai, às vezes, injustiças para alguns e incongruências, quase sempre" (Jornal Correio Popular de 29/04/59).
}

O Zoneamento então é finalmente instituído pela Lei n¹993/59 - Código de Obras e Urbanismo, que instituía 7 (sete) categorias de Zoneamento, sem adotar as proposições de Prestes Maia em relação às atividades comerciais. Após 55 anos decorridos, o título VII desta Lei (capítulo que trata do parcelamento do solo), ainda hoje permanece em vigor.

Segundo Bernardo (2002) a Lei, em relação ao setor terciário recepciona o modelo definido pela sua antecessora (Categorias C1, C2 e C3) com novas definições dos respectivos perímetros. 
Deste modo, C1 e C2 constituem o núcleo central. C1 tem a característica de ser uma zona varejista e de serviços, permitida a verticalização residencial e o coeficiente de aproveitamento pode atingir 8 vezes, excluído o térreo. C2 permite além dos usos citados, comércio atacadista, oficinas que não produzam ruídos e até pequenas indústrias, e o coeficiente máximo atinge 6 vezes. A Zona C3, que anteriormente possuía limitações quanto à altura e número de pavimentos perde estas restrições.

Nas outras zonas (R1 a R5) além dos usos residenciais, são permitidos compartimentos no próprio lote para o uso de escritórios, consultórios ou estúdios, além de usos institucionais. Foi criada uma área denominada "Núcleo Comercial da Zona Residencial Singular", que se estendia da área central até o loteamento do São Bernardo, pela Av. Das Amoreiras.

Além disto, a Prefeitura teria a discricionariedade de autorizar, quando julgasse conveniente a construção de prédios comerciais em lotes de esquina nas áreas residenciais ${ }^{46}$.

Após a crise da segunda metade dos anos 60 e no contexto desenvolvimentista do período militar e do chamado "milagre econômico", em 1971 é aprovado o PPDI- Plano Preliminar de Desenvolvimento Integrado de Campinas (Lei $\left.\mathrm{n}^{\circ} 3.960 / 71\right)$, o qual ratifica a escolha pelo transporte sobre rodas através de seu Plano de Transportes (Lei n 3.964/71).

Em que pese os dois choques do petróleo (1973 e 1979), o período que vai da promulgação do PPDI até a crise da dívida de 1982 é marcado por processos de industrialização e crescimento populacional ainda mais intensos.

Em 1974 é implantado o Distrito Industrial Campineiro, em área lindeira à Rodovia Santos Dumont e ao Aeroporto Internacional de Viracopos, então o único aeroporto do estado de São Paulo a receber jatos de grande porte (O Aeroporto Internacional de Guarulhos no bairro de Cumbica, somente passou a operar em $1985)^{47}$

\footnotetext{
${ }^{46}$ Este padrão vai configurar um tecido urbano muito mais complexo, em termos de usos, do que as grandes manchas monofuncionais que seriam estabelecidas pela Lei de Uso e Ocupação do Solo de 1988 (6.031/88).

${ }^{47}$ Segundo dados da concessionária Aeroportos Brasil, Viracopos é hoje o $2^{\circ}$ aeroporto do país em volume de carga, com cerca de 217.000 ton. transportadas em 2014 e o $6^{\circ}$ em número de passageiros, com quase 10.000.000 transportados em 2014.
} 
A partir da década de 1970, com a consolidação do Campus da UNICAMP (fundada em 1966) no Distrito de Barão Geraldo, a construção do Campus I da PUCCAMP (1976) e a instalação do CPQd da Telebrás (1976), a região da Rodovia D. Pedro I (inaugurada em 1972), que liga Campinas ao Vale do Paraíba (desde a Rod. Anhanguera até a Rod. Presidente Dutra) começa a concentrar investimentos nas área de tecnologia, logística e comerciais de grande porte, com influência muito além do município, em escala metropolitana.

Em 1980 foi inaugurado o Shopping Iguatemi Campinas, em uma gleba a meio caminho entre o centro e a região da Rod. D. Pedro I. Nos últimos 30 anos toda uma série de empreendimentos comerciais se inserem neste arco, entre eles mais 2 shopping centers (Galleria e D.Pedro), 4 centros atacadistas (do tipo que o vende para o consumidor final e por isto recebem a alcunha de "atacarejo"), além de vários varejistas de grande porte (como home centers e varejistas especializados).

O Polo de Alta Tecnologia, com os principais centros de pesquisa em $\mathrm{Tl}$ e Telecomunicações do país, além de diversas empresas de base tecnológica também se situam nesta área.

Este conjunto de investimentos públicos e privados, mesmo em momentos de crise econômica sistêmica em todo o país, movimenta a economia da cidade e a consolida como um polo de comércio e serviços de alcance regional, dentro do processo de metropolização.

Segundo FUPAM (2015), a Macrometrópole Paulista começou a se configurar com a "dispersão concentrada" do parque industrial da Região Metropolitana de São Paulo a partir da década de 1970, abrangendo um raio de cerca de $150 \mathrm{~km}$ a partir da capital paulista, impactando fortemente as Regiões Administrativas de Campinas, de São José dos Campos, de Sorocaba e da Baixada Santista que passam a crescer econômica e demograficamente em taxas superiores à da capital.

Este processo que se acentuou ao longo dos anos vem demandando, a instalação crescente de empresas de logística e de desenvolvimento técnicocientífico que resultou no fortalecimento de instituições e na criação de novos centros de pesquisa em cidades como São Paulo, Campinas e São José dos Campos, sobretudo, mas também em Sorocaba, Santos, Piracicaba e Região do $A B C$. 
A partir dos anos 1990, o processo de macrometropolização levou à criação das Regiões Metropolitanas da Baixada Santista (RMBS - 1996), e de Campinas (RMC - 2000). Posteriormente, foram criadas as regiões metropolitanas do Vale do Paraíba e Litoral Norte (RMVPLN - 2012) e a de Sorocaba (RMS - 2014). Além das RMs institucionalizaram-se as Aglomerações Urbanas (AUs) de Jundiaí (2011) e de Piracicaba (2012).

Em 2012 o Governo do Estado de São Paulo criou a "Macrometrópole Paulista" (MMP), ficando a cargo da EMPLASA a elaboração de estudos e planos de ação para todo seu território.

Segundo FUPAM (2015, p. 15), o processo de macrometropolização continua se expandindo:

"Com o crescimento industrial de setores mais modernos - cada vez mais necessitando de atividades terceirizadas, tanto ligadas à produção, quanto à administração e à pesquisa - e com o crescimento populacional, ampliaramse as atividades do terciário superior48 também fora da capital, desencadeando ciclo de intensificação desta reestruturação urbanoindustrial no território paulista, iniciando, inclusive, expansão seletiva para além das fronteiras do estado".

Desta maneira se tece uma intrincada rede de centros urbanos relacionada ao terciário superior, destacando-se, além da capital paulista, as cidades do Rio de Janeiro, Campinas, São José dos Campos, Ribeirão Preto e Sorocaba (QUEIROGA, BENFATTI, 2007, apud FUPAM, 2015 p.15).

Conforme Queiroga (2008), a partir dos anos 1990 se dá um forte declínio de postos de trabalho nos setores primário e secundário, e a ascensão do setor terciário. Este movimento de elevação de postos de trabalho no setor terciário ocorre de maneira mais intensa, em municípios com maior renda per capita. Neste cenário, dois municípios se destacam: Campinas e Ribeirão Preto, ambos apresentando as maiores taxas de crescimento no setor de serviços.

\footnotetext{
${ }^{48}$ Segundo FUPAM (2015 p.14-15), “[...] as atividades econômicas que integram o "terciário superior” são as atividades de serviço altamente especializados, que se destinam, via de regra, não ao público consumidor, mas às empresas, permitindo, enquanto atividades meio, aumentar a produtividade das atividades fins das empresas para as quais prestam os referidos serviços. Entre as atividades do terciário superior encontram-se as empresas prestadoras de serviços na área de tecnologia da informação (TI), auditoria para grandes corporações, consultoria para empresas financeiras, entre outras.[...].
} 


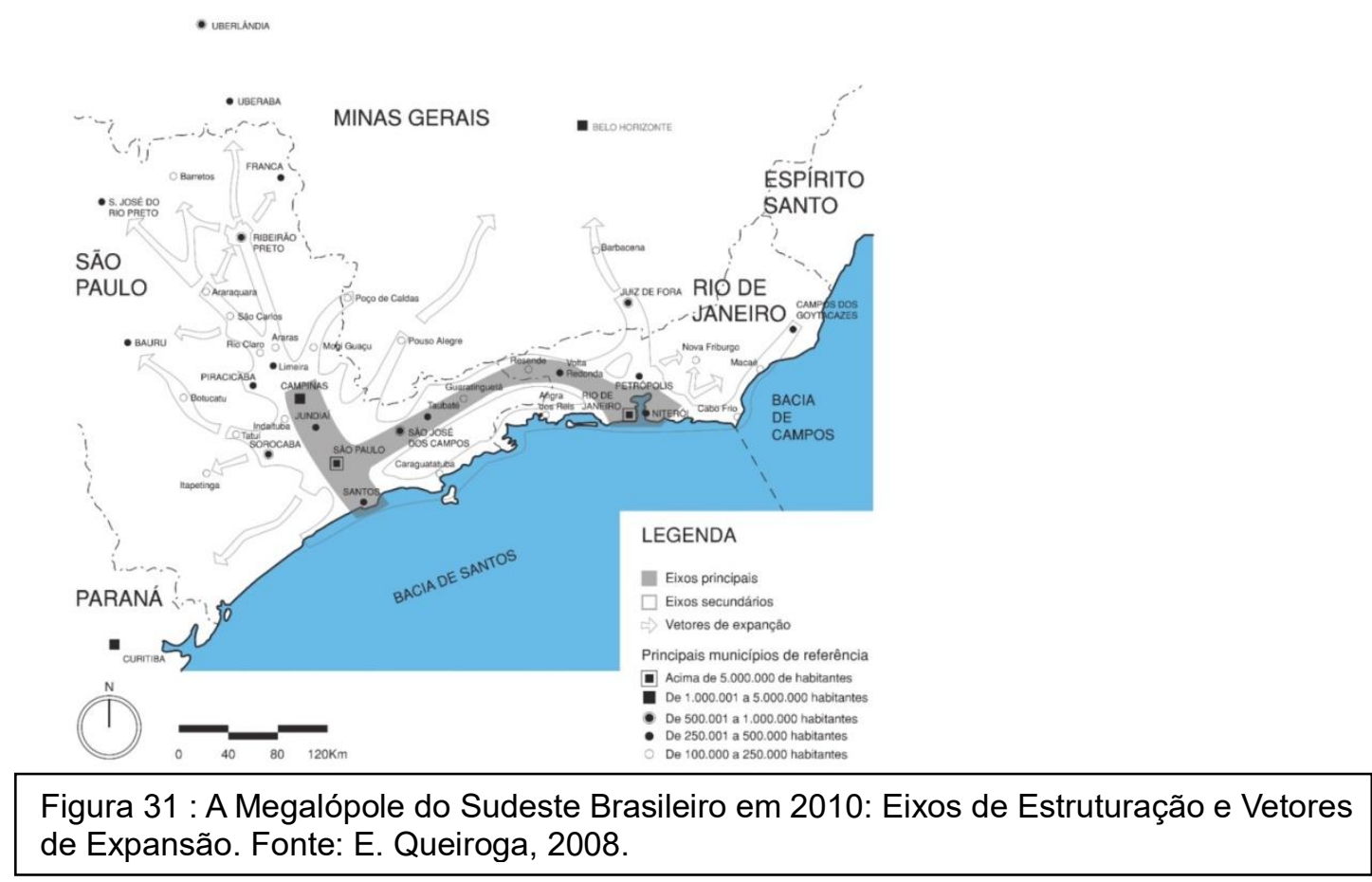

Para Queiroga (Idem), a RMC se insere neste contexto como um de seus núcleos estruturadores. Este autor afirma que a malha rodoviária que corta a RMC cumpre diversos papéis, além de escoamento do tráfego e da produção, como a circulação intra-urbana e intra-metropolitana de indivíduos em direção ao trabalho, escolas, universidades, oportunidades de lazer e consumo (shopping-centers e hipermercados) se configurando como uma espécie de "avenidas metropolitanas" e possibilitando o território a cumprir novo papéis produtivos, de informação e comunicação.

Entre as diversas rodovias que cortam o território de Campinas, analisaremos mais adiante, o eixo da Rod. D. Pedro I (vide figura 32), que se consolida como principal eixo estruturador de atividades de escala metropolitana ou macrometropolitana, que demandam grandes áreas para se estabelecer.

A RMC possui uma população total de cerca de 3 milhões de habitantes (2.797.137, segundo dados do IBGE relativos ao Censo de 2010, conforme tabela 2). Em Campinas o setor terciário (comércio e serviços) responde por $89 \%$ do total de empresas instaladas no município, conforme dados da ACIC. (tabela 3). Ainda, segundo dados já mencionados no Cap. 2 (ACIC, 2014) concentra 72,57\% dos empregos formais no Município. (Tabelas 2 e 3 ) 


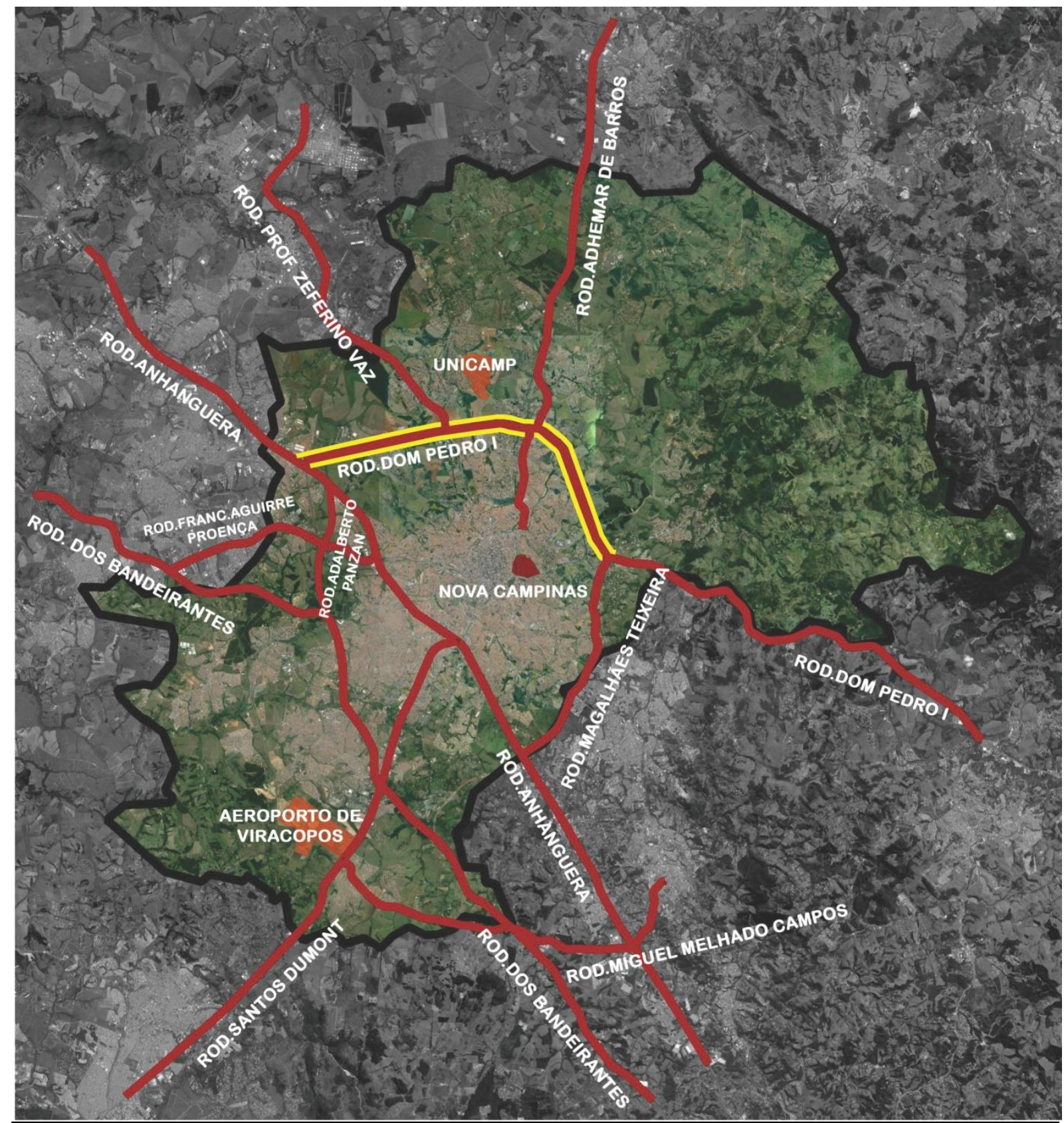

Figura 32: Rodovias em Campinas. Observa-se a posição quase central da Nova Campinas. O eixo da Rod. D. Pedro I está destacado em amarelo. Todo este trecho da rodovia está inserido dentro do perímetro urbano. A partir do início da década de 1970 uma série de investimentos públicos e privados configura esta região como uma nova centralidade de caráter metropolitano. Fonte: a partir de imagem de satélite do Google Earth Pro com anotações do autor. 


\begin{tabular}{|c|c|c|}
\hline \multicolumn{3}{|c|}{ Tabela 2: Dados Estatísticos } \\
\hline \multicolumn{3}{|l|}{ População } \\
\hline Censo IBGE 2010 & 1.080 .999 & \\
\hline Estimativa 2014 & 1.154.616 & \\
\hline \multicolumn{3}{|l|}{ Mão de obra ocupada } \\
\hline 2013 & 577.110 & \\
\hline 2014 & 586.328 & \\
\hline \multicolumn{3}{|l|}{ População Economicamente Ativa - PEA } \\
\hline 2013 & 603.668 & \\
\hline 2014 & 628.763 & \\
\hline \multicolumn{3}{|l|}{ PIB } \\
\hline 2012 & $R \$ 42.766 .020,00$ & \\
\hline PIB per Capita (2012) & $\mathrm{R} \$ 38.843,95$ & \\
\hline \multicolumn{3}{|l|}{ FONTE: ACIC - Associação Comercial e Industrial de Campinas } \\
\hline Tabela 3: Empresas por segmento & 2014 & 2013 \\
\hline \multicolumn{3}{|l|}{ Econômico } \\
\hline Extrativa Mineral & 29 & 28 \\
\hline Indústria Transformação & 3.909 & 3.944 \\
\hline Serv. Ind. Util. Pública & 144 & 152 \\
\hline Construção Civil & 3.387 & 3.198 \\
\hline Administração Pública & 56 & 55 \\
\hline Comércio & 27.785 & 27.254 \\
\hline Serviços & 39.635 & 36.990 \\
\hline Agropecuária & 745 & 666 \\
\hline Total & 75.690 & 72.287 \\
\hline
\end{tabular}

FONTE: ACIC - Associação Comercial e Industrial de Campinas

Apesar desta clara vocação para o setor terciário ${ }^{49}$, a legislação de Uso e Ocupação do Solo vigente (como a grande maioria das legislações urbanísticas), o relega a um papel de menor importância no tecido urbano.

Em dezembro de 1988 entra em vigor a nova Lei de Uso e Ocupação do Solo - LUOS (Lei n 6.031/88), que segue o modelo da legislação de 1972 de São Paulo e que permanece em vigor até hoje.

Inicialmente estruturada em 18 Zonas, sofreu tantas alterações e adendos que com suas leis acessórias resultam atualmente num total de 59 tipos diferentes

\footnotetext{
${ }^{49}$ A própria origem da cidade está ligada aos fluxos de mercadorias: pouso de tropeiros na rota bandeirante conhecida como "caminho dos Guaiases".
} 
de zoneamento.

Em Campinas, apesar destes 59 tipos de zoneamento diferentes, a maior parte do território (+ de $70 \%$ segundo dados da SEPLAN - Secretaria Municipal de Planejamento e Desenvolvimento Urbano) é composta por zonas "estritamente residenciais" ${ }^{50}$, onde as atividades de comércio e serviços recebem classificações como "atividade proibida", "com restrições quanto à localização" ou então como atividade "tolerada" - não podendo sofrer ampliações (ainda assim, limitada a algumas categorias de atividades de comércio e serviços) e desde que tivesse sido instalada no local, antes da promulgação da referida lei.

Isto acontece mesmo se o imóvel se situar em uma avenida de grande fluxo de veículos, pouco adequada à implantação do modelo de residências unifamiliares, onde poderia receber atividades terciárias mescladas a um maior adensamento de maneira a aproveitar os eixos de circulação, inclusive em relação à eficiência do transporte coletivo.

Tomemos um exemplo hipotético, de um loteamento em uma gleba de 1.000.000 de $\mathrm{m}^{2}$ situada em zoneamento Z-4 que é estritamente residencial: mesmo que o viário estipulado exija avenidas com 2 pistas e $25 \mathrm{~m}$ de largura, os lotes defronte a esta avenida serão sempre destinados à implantação de unidades habitacionais unifamiliares, sendo vedada qualquer ocupação comercial. O projeto de loteamento é obrigado a seguir a mancha de zoneamento, sem permitir o surgimento de atividades de comércio de serviços voltadas ao abastecimento e/ou consumo da população, ainda que utilizadas no deslocamento casa-trabalho.

O mesmo ocorrerá em um loteamento padrão popular, em que o lote mínimo de $125,00 \mathrm{~m}^{2}$ possibilita um adensamento 4 vezes maior do que os lotes de $500,00 \mathrm{~m}^{2}$ previstos na Z-4, ou 8 vezes maior que os $1.000,00 \mathrm{~m}^{2}$ estipulados em Z-4 BG, gerando muito mais fluxo de pessoas, o que favorece o surgimento de estabelecimentos de comércio e serviços.

Este padrão de ocupação tem se multiplicado nas periferias do município de Campinas, em decorrência do boom imobiliário da primeira década do Séc. XXI,

\footnotetext{
${ }^{50}$ www.zoneamento.campinas.sp.gov.br Estas zonas, que vão da Z2 à Z8, (com exceção da Z-5, que é classificada como "predominantemente residencial") e suas subvariantes (APA, BG, etc.) abarcam uma área de mais de $70 \%$ do perímetro urbano.
} 
reforçando o uso monofuncional e contribuindo para o aumento da informalidade no setor terciário.

Este movimento é agravado com a proibição, a partir da promulgação da Lei Complementar n¹5/2006 (Novo Plano Diretor), de que empreendimentos habitacionais de interesse social (EHIS) sejam executados em todo o território do Município.

Somente ficam liberadas para este tipo de empreendimento, a Macrozona 5 (Ouro Verde/Campo Grande) e o extremo sul da Macrozona 4 (Pque. Jambeiro), até que todos os Planos Locais das 9 Macrozonas entrassem em vigor ${ }^{51}$.

Estas áreas que abrigam o perfil de renda mais baixa no Município (além do maior contingente de população em situação de vulnerabilidade), apresentam deficiências de infraestrutura e equipamentos públicos, e poucas áreas onde a instalação de comércio e serviços são permitidos, impedindo o surgimento de empregos que poderiam contribuir para a diminuição dos deslocamentos pendulares cotidianos $^{52}$.

Em relação à ocupação (que define tipologias e parâmetros construtivos), a LUOS preconiza 7 tipologias de edificações destinadas aos usos comerciais, de serviços e institucionais (CSE, CSE-1, CSE-2, CSE-3, CSE-4, CSE-5, e CSE-6), além de mais 5 tipologias prevendo uso misto (HCSE, HCSE-1, HCSE-2, HCSE-3, HCSE-4 e HCSE-5) ${ }^{53}$.

\footnotetext{
${ }^{51}$ Esta medida foi adotada para coibir atividades especulativas, com utilização de padrões construtivos muito mais permissivos em termos de adensamento (EHIS) em áreas de alto valor fundiário e baixa densidade. Estes empreendimentos que deveriam ter a destinação de baixa renda acabavam por terem sua destinação deturpada, sendo vendidos para Classes A e B. O Plano Diretor adotou uma perspectiva otimista de que todos os Planos Locais estariam consolidados até o fim de 2008 e então teríamos as ZEIS definidas em todo o território, o que permitira uma boa distribuição de EHIS. Até o início de 2014, porém, apenas o Plano da Macrozona 5 se encontra plenamente em vigor.

${ }^{52}$ É sintomático que um empreendimento como o Jardim Bassoli, situado no extremo da região sudoeste, distando cerca de vinte quilômetros do centro da cidade, tenha se tornado estudo de caso para avaliação do programa Minha Casa, Minha Vida a pedido do Ministério Público Federal junto à PUC-Campinas. Inaugurado em 2013, possui 2.380 unidades habitacionais em 119 blocos, divididos por sua vez em 19 condomínios. Foi projetado para uma população estimada de 10.000 habitantes e é acessado somente pelo saturadíssimo corredor da Av. Jonh Boyd Dunlop / Estrada do Campo Grande. A respeito do empreendimento, o portal de notícias G1 publicou uma página em 26/11/13 cuja chamada diz o seguinte: "Bairro de programa do governo fica sem saúde e educação, diz estudo: Projeto em Campinas destaca falta de infraestrutura. E a matéria ressalta que o caso se transformou em um estudo pioneiro do Ministério Púbico Federal (MPF) em parceria com a PUC-Campinas, que aponta falhas de planejamento e execução. Segundo este estudo, o conjunto habitacional foi construído em uma área longe do centro da cidade e sem infraestrutura urbana como escolas e postos de saúde, além de comércio local. Entrevistada pela reportagem uma moradora declarou: "Aqui não tem nem emprego nas proximidades. Não tem uma padaria, um mercado".

${ }^{53}$ As tipologias mistas diferem muito pouco entre si. HCSE-1 faz aquele padrão típico dos salões comerciais no térreo com uma ou duas unidades residenciais no pavimento superior. HCSE-2, HCSE-3 e HCSE-4 diferem apenas coeficiente mas em todas o comércio e os serviços ficam restritos ao térreo e sobreloja, o que no caso dos serviços, especialmente, não faz muito sentido. Já HCSE-5 diz respeito somente à Zona central, Z-17 e segue o mesmo padrão.
} 
À primeira vista, pode parecer que tal profusão de tipologias é capaz de dar conta da diversidade necessária de edificações para o setor terciário. Só que uma olhada mais atenta revela que as diferenças são mínimas, relacionadas mais ao número de pavimentos permitidos e pequenas diferenças de taxa de ocupação, sendo o ponto principal o aumento progressivo do coeficiente de aproveitamento.

No caso das ocupações mistas, praticamente só o que muda é o coeficiente, por que as atividades de comércio e serviços estão sempre segregadas ao térreo ou sobreloja, o que nem sempre vai de encontro às reais necessidades do terciário.

Não está contemplada na legislação, uma maior diversidade de modelos mistos com mais pavimentos comerciais, escritórios de serviços e habitacionais, ou mesmo a possibilidade de se fazer em um mesmo empreendimento torres comerciais e residenciais, unidas por um ou mais pavimentos de lojas, por exemplo.

Em relação aos usos, inicialmente especifica 33 categorias em relação às atividades comerciais, de serviços e institucionais, sendo 10 comerciais, 19 de serviços e 4 institucionais. Isto sem contar as variantes de zoneamento como as categorias do zoneamento específico do distrito de Barão Geraldo (Lei 9.199/96) e as demais leis específicas como a da APA (Lei 10.850/00) e do Polo II de Alta Tecnologia - CIATEC (Lei 8.252/95), todas com parâmetros distintos e específicos.

Quanto ao uso dos imóveis, em relação ao setor terciário o anexo de atividades da LUOS pretende classificar e disciplinar todas as atividades possíveis no espaço urbano, o que nos parece um tanto ingênuo, ainda mais em uma lei que permanece há mais de 25 anos em vigor, período onde muitas atividades originais deixaram de existir ou ter relevância (escola de datilografia e videolocadora, por exemplo.) e outras, especialmente as ligadas à revolução tecnológica da informática (venda e manutenção de celulares, cursos de programação, monitoramento remoto, outsourcing de suprimentos e impressoras, etc.) surgiram sem que fossem incluídas. Este anexo relaciona 229 atividades comerciais possíveis e 299 atividades de serviços e institucionais, divididas nas 33 categorias citadas.

No caso de Campinas, é paradigma desta inadequação do modelo de listas estanques de atividades, a situação das chamadas "lan houses" que surgiram com força no fim da década de 90 , como o principal ponto de acesso à internet, multiplicando-se de forma impressionante. 
Hoje, com banda larga mais acessível nas residências e a disseminação de dispositivos pessoais (tablets e smartphones), inclusive com acesso wi-fi gratuito em muitos estabelecimentos comerciais, como lojas, restaurantes e até academias e consultórios, praticamente se restringiram ao um nicho de jogos on-line.

Estas lan-houses, não conseguiam obter o Alvará de Uso por que sua atividade não estava definida no anexo de atividades da Lei $\mathrm{N}^{\circ} 6.031 / 88$. A lei neste caso é anterior à própria internet e este modelo de legislação não dá conta das mudanças tecnológicas sociais e culturais aceleradas dos últimos anos do Séc. XX.

Outro exemplo interessante é o caso das gráficas que estão classificadas no anexo de atividades como indústrias (IN-15) e somente podem se localizar em zoneamento compatível com a atividade industrial. Até é possível compreender que à época da promulgação da LUOS, uma gráfica causasse certa incomodidade (offset, linotipos, etc.), mas com a revolução da informática, uma única máquina em uma sala de escritório pode ter a capacidade de produção de uma indústria dos anos 70 , e sem produzir barulho ou odores incômodos.

O mesmo vale para as agências bancárias que eram enormes e geravam grandes fluxos de pessoas e veículos, concentrados em períodos específicos do mês. Hoje as agências cabem no bolso, em um celular, e se o cliente tiver necessidade por qualquer motivo, de ir à agência física, é muito melhor que ela esteja próxima de sua residência e trabalho.

Um avanço neste sentido foi a promulgação da Lei $n^{\circ} 12.195$ de 2004, que modificou o entendimento da listagem de anexos de usos, dando margem à interpretação de algumas categorias que eram inexistentes por similaridade e não mais por lista fechada, além de trazer para as categorias de comércio local básico (CL-1) e comércio e serviços locais (CL-2) toda uma série de atividades necessárias ao cotidiano, cuja frequência de compra e expectativa de proximidade também estão sendo relativizados.

Em relação aos exemplos anteriores, incluiu-se "ciber-café" (onde se procurou abrigar as lan-houses), copiadoras e agências bancárias na categoria CL-2, porém outros usos acabam ficando à mercê da boa vontade do agente público que irá analisar o pedido de Alvará de Uso.

Este problema é aumentado pelo fato de que o setor responsável pela 
emissão de Alvarás de Uso (Coordenadoria de Uso do Solo da SEMURB) faz uso da do código do CNAE (Cadastro Nacional de Atividades Econômicas) constante do contrato social de uma empresa para decidir pelo seu enquadramento.

Isto gera problemas quando o contrato social apresenta muitas atividades, mesmo se no local escolhido nem todas elas serão desenvolvidas: se no contrato social, entre as atividades descritas constar a palavra "atacado", a empresa não conseguirá o Alvará de Uso em uma zona que só permita o varejo, ainda que na unidade pretendida somente seja esta a atividade proposta ${ }^{54}$

Apesar de a mudança do entendimento ocorrida no anexo de usos, ter sido benéfica (ainda que incompleta), sua eficácia fica prejudicada devido ao fato de mesmo estas atividades comerciais básicas terem a necessidade de suporte em um zoneamento onde possam se desenvolver, e de na maior parte do território existirem restrições à localização do comércio e serviços.

Entre as Zonas que representam a maior porção do território de Campinas, as zonas 2, 3 e 4 (estritamente residenciais) somente permitem o comércio com restrições quanto à localização (uso de hachuras, no mapa de zoneamento, criando uma espécie de subcategoria, podendo ser modificada por Decreto) ${ }^{55}$.

As Zonas 6 e 7 (estritamente residenciais multifamiliares, com possibilidade de verticalização adensada) colocavam as atividades comerciais, mesmo as de comércio local, na condição de uso tolerado, quando não há possibilidade de ampliação, o que será analisado mais adiante.

Posteriormente, ao se verificar a incompatibilidade de classificar comércio local como tolerado em zonas verticalizadas e adensadas, remendou-se mais uma vez a legislação em 2003, com a edição da Lei $n^{\circ} 11.471 / 03$ que incluiu as categorias de CL-1 e CL-2 da condição de tolerado para permitindo, mantendo, contudo, as restrições na ocupação quanto ao porte da edificação, que permaneceram limitadas ao pequeno porte.

Neste sentido, a adoção de códigos rígidos e detalhistas de zoneamento

\footnotetext{
${ }^{54}$ Não existe legislação que obrigue à PMC a utilizar o CNAE como referência. É uma prática que foi se sedimentando com o tempo e a inércia do poder público em rever seus procedimentos burocráticos e que tem impossibilitado uma aplicação de procedimentos mais racionais.

${ }^{55} \mathrm{Na}$ Zona 4, zoneamento muito comum nas regiões mais valorizadas da cidade, por exemplo, não se conhece nenhum caso de áreas que tenham recebido essas hachuras.
} 
serve como já vimos, como um inesgotável campo para intervenções pontuais atendendo a interesses muitas vezes escusos.

\title{
3.2 Parâmetros e definições da LUOS:
}

Além das questões específicas do zoneamento, temos outras disposições da LUOS que afetam diretamente as atividades do setor terciário.

\begin{abstract}
Questões relativas a restrições do porte das edificações, vagas de estacionamento, classificação de usos como "tolerados" e a necessidade de concordância da vizinhança para autorizar alguns usos são problemas que, mais do que organizar o espaço do terciário, acabam por estimular a informalidade, a insegurança e o desconforto urbano.
\end{abstract}

Em outras situações, o próprio poder público cria através das muitas leis de anistia e de flexibilização, as condições que perpetuam uma espécie de "faz-deconta", onde discurso e realidade ficam cada vez mais apartados.

As restrições de porte aparecem no texto da LUOS da seguinte maneira:

\section{SEÇÃO IV - Lei 6.031/88 \\ DA CLASSIFICAÇÃO DOS ESTABELECIMENTOS QUANTO À ÁREA CONSTRUÍDA}

Art. 14 - Os estabelecimentos comerciais, de serviços e institucionais a serem instalados nas edificações classificam-se, em função do porte, em: (nova redação de acordo com a Lei $n^{\circ}$ 9.785, de 01/07/1998 (56. $^{56}$.

I Estabelecimentos de pequeno porte - Estabelecimento instalado em unidade autônoma ou módulo comercial, com área privativa máxima de $500,00 \mathrm{~m}^{2}$, para atividades comerciais e de serviços, e de $1.000,00 \mathrm{~m}^{2}$ para atividades institucionais. (nova redação de acordo com a Lei $n^{\circ} 9.785$, de 01/07/1998).

II Estabelecimentos de médio porte - Estabelecimento instalado em unidade autônoma ou módulo comercial, com área privativa máxima de $1.000,00 \mathrm{~m}^{2}$ para atividades comerciais e de serviços, e de 2.500,00m² para atividades institucionais. (nova redação de acordo com a Lei n 9.785, de 01/07/1998).

III Estabelecimentos de grande porte - Estabelecimento instalado em unidade autônoma ou módulo comercial, com área privativa máxima acima de $1.000,00 \mathrm{~m}^{2}$ para atividades comerciais e de serviços, e acima de

\footnotetext{
${ }^{56}$ A Lei ${ }^{\circ}$ 9785/98 que fez alterações nas definições do porte, basicamente passou definição de pequeno porte de $250,00 \mathrm{~m}^{2}$ para $500,00 \mathrm{~m}^{2}$, o médio porte de $250,00 \mathrm{~m}^{2}$ para acima de $500,00 \mathrm{~m}^{2}$ e o grande para acima de $1.000,00 \mathrm{~m}^{2}$, além de excluir do cálculo as áreas de vagas de garagem.
} 
$2.500,00 m^{2}$ para atividades institucionais. (nova redação de acordo com a Lei $n^{\circ}$ 9.785, de 01/07/1998).

Parágrafo único - Não serão consideradas para cálculo do porte do estabelecimento, as áreas das garagens a ele vinculadas. (acrescido pela Lei $n^{\circ}$ 9.785, de 01/07/1999).

Fonte: Biblioteca Jurídica da P.M.C.

A restrição de porte aparecerá em várias zonas, onde especifica determinados tipos de ocupação para cada porte, ou mesmo proibindo estabelecimentos de médio ou grande porte em muitas delas.

Pensado como uma proteção contra atividades, cujo tamanho possa trazer incômodos ao entorno residencial, este dispositivo restringe a evolução das atividades comerciais e de serviços, que muitas vezes estavam já instaladas na vizinhança quando da promulgação da LUOS, impedindo de continuar atendendo adequadamente as necessidades da população, através de ampliação (inclusive em áreas onde a própria LUOS previu o adensamento através da verticalização).

Tomemos como exemplo o bairro do Cambuí, cuja localização de fácil acesso, e densidade de população e renda (de moradores e pessoas que circulam pelo bairro diariamente), tornaram-no uma centralidade comercial atrativa para a cidade toda e até mesmo para moradores da RMC.

Independentemente de quaisquer restrições impostas pela legislação, as limitações de porte acabam por dificultar o atendimento adequado à própria população do bairro que está zoneado majoritariamente como Z-6 e Z-7, e destinado majoritariamente ao uso habitacional multifamiliar (com coeficientes de até 3 vezes a área do lote) e onde, contraditoriamente, o comércio local básico (CL-1 e CL-2) somente poderá se estabelecer em edificações de pequeno porte, impedindo o surgimento de supermercados ${ }^{57}$, por exemplo.

Como não se satisfaz adequadamente às necessidades de consumo dos moradores, no caso, de alta renda e com certeza proprietários de veículos irão se deslocar para poder responder a estas necessidades, impactando outras áreas com um trânsito de veículos que poderia ser evitado.

A LUOS (posteriormente alterada pela Lei $n^{\circ}$ 9.785/98, como vimos)

\footnotetext{
${ }^{57}$ Há uma unidade do Grupo Pão de Açúcar, em frente ao Centro de Convivência Cultural (Praça Imprensa Fluminense), na Rua General Osório, com cerca de $2.500,00 \mathrm{~m}^{2}$, mas esta já existia desde o início dos anos 70 e está impedida de ampliar por que o uso de supermercado enquadra-se como CG-1, o qual na Zona 7 está classificado como tolerado.
} 
estabelece que a definição de porte aplica-se à área de uma unidade autônoma ou módulo comercial.

Como o projeto de aprovação de uma edificação comercial não define seu uso (partindo-se do pressuposto de que uma edificação, ao longo de sua vida útil pode ter várias utilizações) e segundo o Decreto $n^{\circ} 16.295 / 2008$ que disciplina a aprovação de projetos no município o modelo gráfico do projeto de aprovação é do tipo simplificado, surgem vários projetos que apresentam módulos comerciais (como se fossem lojas autônomas), mas na verdade pertencem a um único estabelecimento.

Como exemplos, podem ser citadas uma unidade do grupo Carrefour (bandeira Carrefour Bairro) com cerca de 2.250,00 $\mathrm{m}^{2}$ mais subsolo de vagas, na Rua Major Solon (Z-7) e uma unidade da rede OBA com cerca de 900,00, mais subsolo de estacionamento, na Rua Maria Monteiro (Z-6).

Estas lojas além de teoricamente não poderem funcionar por serem enquadradas como CG-1 (teoricamente o OBA pode ser enquadrado como CL-1, comércio local básico, como quitanda, mas isto seria incompatível com as características e tamanho de supermercado) também excedem o porte máximo das Zonas 6 e 7 que é o pequeno porte (máximo de 500,00 m²). Segundo consulta informal ao setor responsável pela emissão de Alvarás de Uso, até hoje a situação do Carrefour Bairro não está resolvida e a unidade da rede Oba tem Alvará parcial.

O uso dos módulos comerciais se disseminou em todas as zonas em que há restrição de porte ao comércio e serviços, nem sempre de maneira a contornar as restrições (ao camuflar empreendimento de maior porte), mas invariavelmente demonstrando que em algumas áreas mais adensadas estas restrições vão contra as dinâmicas do próprio adensamento. 


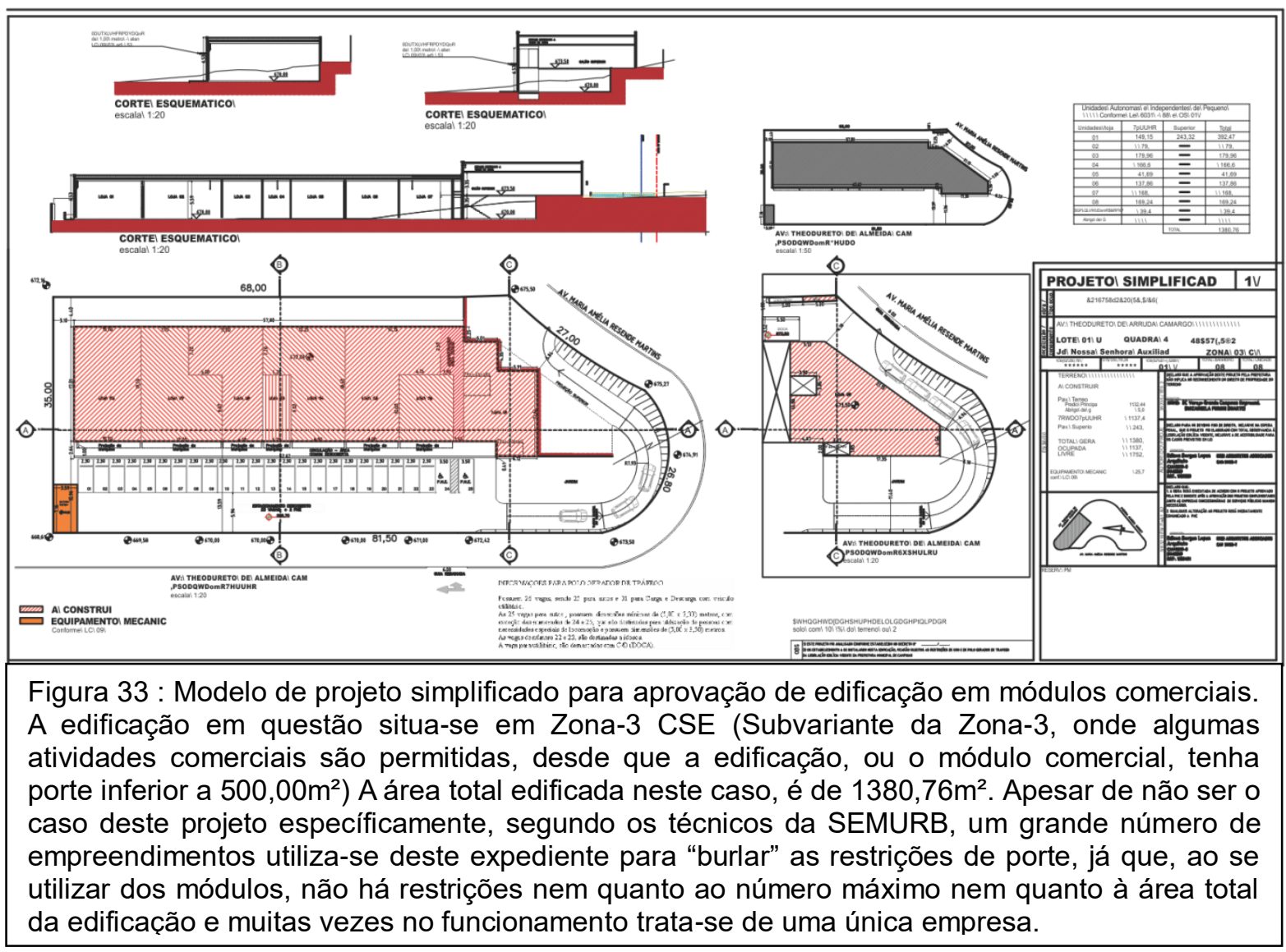

O objetivo de se restringir o porte parte da premissa de que maiores portes significam maiores impactos, podendo atrair fluxos exógenos que atrapalhem o "sossego" do bairro, o que acaba sendo uma argumentação falha se levarmos em consideração que quando construída em módulos, a edificação tem seu tamanho restringido apenas pelo tamanho do terreno e o coeficiente a ser aplicado ${ }^{58}$ (derivado do zoneamento e tipo de ocupação a ser utilizado).

É muito difícil entender este nível de incoerência, ou seja, como a legislação ao tratar de uma área já densamente verticalizada em 1988, estipula um padrão de zoneamento (Z-6 e Z-7) que estimula o adensamento habitacional (tipologias HMV-2 e HMV-3), inibindo, ao mesmo tempo, o desenvolvimento do terciário, inclusive o de suporte ao cotidiano:

VI - Zona 6 - zona estritamente residencial, destinada basicamente ao uso habitacional multifamiliar; o comércio, os serviços e as instituições existentes serão tolerados;

\footnotetext{
${ }^{58}$ Vide projeto-exemplo da figura 24
} 
VII - Zona 7 - zona estritamente residencial, destinada basicamente ao uso habitacional multifamiliar; o comércio, os serviços e as instituições existentes serão tolerados;

Como vimos esta situação, somente foi amenizada (parcialmente) em 2003/2004 com as Leis 11.471/03 e 12.195/04.

Tolerado.

Eis uma palavrinha extremamente controversa e que permeia grande parte da relação da LUOS com o comércio e serviços, aparecendo em maior ou menor grau em 13 das 18 zonas originais. Basicamente a definição de uso tolerado no Artigo 16 da LUOS diz:

"Tolerados: Usos existentes ou usos estabelecidos a mais de um ano não enquadrados em categorias e sub-categorias permitidas ou toleradas no zoneamento da área, aceitando-se sua permanência, observadas outras exigências do Código de Obras e Urbanismo, desde que não haja aumento de áreas edificadas".

Fonte: LUOS - Biblioteca Jurídica da P.M.C.

Resumindo: se o comércio já existe, então ele pode ficar, mas deve permanecer estático, ignorando a dinâmica urbana.

Isto vai contra todos os princípios de economia urbana.

Se entre as diversas ações empreendidas pelos agentes envolvidos com as atividades terciárias em sua busca pela centralidade, a localização do estabelecimento comercial exerce um papel primordial, por que impedir que a dinâmica urbana siga se desenvolvendo, obrigando o estabelecimento que pretende se aprimorar, a se mudar para outras regiões, impedindo-o inclusive de continuar a atender ao seu público habitual?

E se ele é tão especial que pode atrair público de outras regiões da cidade, basta que então se exija compensações que adequem sua acessibilidade e mitiguem os impactos na vizinhança (EIV, melhorias de acessibilidade viária, vagas, etc.) analisando tecnicamente caso a caso e solicitando as adequações necessárias para permitir sua ampliação.

Lembremo-nos do Shopping Pátio Higienópolis, em São Paulo: Inicialmente os moradores do bairro se mostraram contrários a sua implantação, por temer fluxos 
de pessoas de outras áreas da cidade, porém hoje a maioria utiliza-se do shopping para suas necessidades de consumo e obtenção de serviços. A própria exigência de vagas (em conformidade com a legislação) quando de sua última ampliação se mostrou exagerada, já que grande parte dos usuários é moradora das vizinhanças e vai a pé até ele. Hoje, pode-se dizer que é um exemplo de sucesso de integração de centro comercial em uma vizinhança, e sua escala e dimensões estão bem inseridas dentro do contexto do tecido urbano pré-existente.

Há também o benefício das leis de regularização (anistia) que se sucedem e servem de estímulo às construções irregulares: devido à quantidade de construções com algum tipo de irregularidade, estas leis se tornam politicamente muito interessantes, especialmente para o legislativo municipal, resultando em uma espécie de círculo vicioso que com a desculpa de resolver situações já estabelecidas, acabam por estimular novas irregularidades, criando uma espécie de "cultura do puxadinho", onde todos se sentem a vontade para edificar sem se ater à legislação, pois, sempre se aguarda uma lei de regularização para remediar a situação.

Desde 1988, contabilizamos 11 Leis deste tipo, sendo o caso mais extremo o da Lei $n^{\circ} 11.603 / 03$, que ficou em vigor por 9 anos até ser revogada pela Lei Complementar $n^{\circ} 34$ de 2012, que também objetivava a regularização de edificações clandestinas, mas de modo menos permissivo. A Lei $11.603 / 03$ permitia a regularização de uma edificação que estivesse em desacordo com os seguintes parâmetros:

[...]Art. $2^{\circ}$ - A presente lei beneficiará as edificações irregulares em infração aos dispositivos das leis: 6.031/88, 9199/96, 8.232/94 e 7.413/92.

I Taxa de ocupação do lote;

II Afastamentos e recuos;

III Pé-direito,

IV Índice de aproveitamento (área máxima de construção)

$V$ Número de pavimentos e altura da edificação;

VI Vagas de estacionamento, carga e descarga, embarque e desembarque, caminhões e ônibus.

Fonte: Biblioteca Jurídica da P.M.C.

Tudo sem limite máximo definido, e ainda, com o agravante de que não estipulava multa para estas irregularidades. Esta lei tornou-se indutora de um boom de construções irregulares, ao invés de legalizar edificações clandestinas 
construídas antes da sua vigência. Muitos empreendimentos ligados ao terciário, como lojas, restaurantes, e até prédios de escritórios se aproveitaram desta lei, muitas vezes construindo pavimentos inteiros, além do permitido.

Em grande parte do território de Campinas, o terciário é tratado como uma espécie de atividade "invasora" e não algo fundamental ao cotidiano (chega a ser banido das zonas 4 e 8, à exceção de escolas, e mesmo assim dependendo da concordância da vizinhança - categoria de uso EL). Como já comentamos anteriormente, isto é potencializado no tratamento dado aos bairros da elite, onde há a total proibição ao comércio e aos serviços (excetuando-se mais uma vez o uso EL) definida pela alínea d do Inciso III do Artigo 27 da Lei n 6.031/88 - LUOS:

[...]III - ZONA 3 - zona estritamente residencial, destinada aos usos habitacionais unifamiliares e multifamiliares; o comércio, os serviços e as instituições de âmbito local serão permitidos com restrições quanto à localização;

a)...

b)...

c)...

d) nos quarteirões pertencentes aos loteamentos denominados: Jardim Santa Genebra, Cidade Universitária Campineira, Jardim Santa Margarida, Chácaras Belvedere, Condomínio Rio das Pedras, Parque Taquaral, Chácaras Primavera, Parque Alto do Taquaral, Jardim Nossa Senhora Auxiliadora, Jardim Guanabara, Nova Campinas, Jardim Paraiso, Jardim Guarany, Jardim Santa Marcelina, Parque Nova Campinas, Jardim Carlos Gomes, Jardim Marília, Jardim Bom Retiro, Jardim Alto do Cambuí, Jardim São Carlos, Jardim Itamarati, Condomínio Parque Nova Campinas, Jardim das Paineiras, Jardim Lumen Christi, Jardim Flamboyant, Vila Brandina, Bairro das Palmeiras, Parque da Hípica, Sitios de Recreio Gramado, Chácaras Alto da Nova Campinas, definidos como zona 3, ficam proibidos o uso habitacional multifamiliar vertical e os usos comerciais, de servicos e institucionais, com exceção do uso EL que não terá restrições quanto à localização, na dependência de consulta e concordância da população do bairro $^{59}$. (conforme redação dada pelo art. 37 da Lei 6.367/90)

Fonte: Biblioteca Jurídica da P.M.C., com grifos nossos.

Como a dinâmica urbana e suas demandas não se coadunam com a segregação do terciário de uma porção tão grande do território (mas não se consegue romper com um discurso de separação de funções já arraigado no imaginário coletivo), o Poder público busca uma via de acomodação entre os

\footnotetext{
${ }^{59}$ Neste caso é interessante notar que a concordância da população do Bairro nunca foi objeto de regulamentação, deixando mais um nó frouxo a mercê de análise subjetiva por parte do funcionário ou administrador de plantão.
} 
diversos interesses, com as chamadas "Leis de flexibilização".

Estas leis, como o próprio nome indica, flexibilizam as restrições, condicionando a possibilidade de algumas atividades serem exercidas em imóveis originalmente residenciais, desde que certos parâmetros (normalmente o porte e a existência de habite-se anterior a uma determinada data) sejam atendidos.

O primeiro exemplo foi a Lei $n^{\circ} 8.737 / 1996$ :

LEI N 8.737 DE 10 DE JANEIRO DE 1996

(Publicação DOM 11/01/1996: p.2-3)

\author{
DISPÕE SOBRE A CONCESSÃO DE ALVARÁ DE USO EM \\ EDIFICAÇÕES EXISTENTES EM ÁREAS DO MUNICÍPIO DE CAMPINAS \\ ZONEADAS PELA LEI No 6031/88 EM Z1, Z2, Z3, Z5, Z6 E Z7, \\ ESTABELECE PARAMMTROS CONSTRUTIVOS PARA HABITAÇÕES DE \\ INTERESSE SOCIAL E DÁ OUTRAS PROVIDÊNCIAS.
}

A Câmara Municipal aprovou e eu, Prefeito do Município de Campinas, sanciono e promulgo a seguinte lei:

Artigo $1^{\circ}$ - As edificações aprovadas e com habite-se à data da publicação desta lei, situadas em áreas do Município de Campinas zoneadas como Z1, Z2, Z3, Z5, Z6, Z7, além do uso habitacional permitido pela lei $n^{\circ} 6.031 / 88$, poderão ser destinadas, parcialmente ou totalmente, aos usos comerciais, de serviços, institucionais e industriais, desde que observadas as condições estabelecidas por esta lei.

Parágrafo único - As edificações a serem utilizadas para as atividades permitidas por esta lei deverão, quando necessário, adaptar suas instalações para compatibilizarem-se com as condições de funcionamento do uso pretendido.

Artigo $2^{\circ}$ - A concessão do alvará de uso ater-se-á às atividades de caráter local, de pequeno porte, e consideradas não incômodas.

Artigo $3^{o}$ - Consideram-se como de usos incômodos, as atividades comerciais, de prestação de serviços, institucionais e industriais, capazes de produzir conflitos com a vizinhança, pelo tipo de impacto negativo que geram, tais como os decorrentes de: ruidos, trepidações, explosões, gases, poeiras, fumaças, odores, conturbações no tráfego, resíduos nocivos ou perigosos, e outros similares.

Artigo $4^{\circ}$ - A concessão do alvará de uso de que trata o Artigo $1^{\circ}$ desta lei poderá ocorrer nas seguintes condições:

I - Quando a atividade for exercida pelo interessado, no próprio imóvel de residencia, desde que:

a) a edificação e as construções acessórias a serem utilizadas para a moradia e o exercício da atividade tenham área igual ou inferior a 250,00 $m^{2}$ (duzentos e cinquenta metros quadrados).

b) as atividades a serem exercidas enquadrem-se nas seguintes categorias:

- CL1, CL2;

- $S P 1, S P 2$

- SL1, SL2, SL3.

$\S \mathbf{1}^{\circ}$ - Nas condições previstas no inciso I deste artigo será dispensada a exigência da Lei de Pólos Geradores de Tráfego - Lei n ${ }^{\circ}$ 8.232/94, no que se refere às áreas de estacionamento. 
II - Quando a atividade for exercida em imóvel, independente da vinculação com a moradia, desde que:

a) a edificação e as construções acessórias a serem utilizadas para o exercício da atividade tenham área igual ou inferior a $250,00 \mathrm{~m}^{2}$ (duzentos $\boldsymbol{e}$ cinquenta metros quadrados);

b) as atividades a serem exercidas enquadrem-se nas seguintes categorias:

- CL1, CL2;

- $C G 1$;

- $S P 1, S P 2$;

- SL1, SL2, SL3;

- $S G 1, S G 2, S G 6 ; e$

- EL.

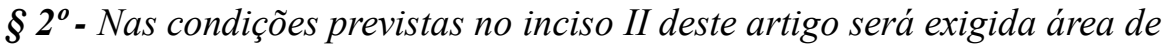
estacionamento, de acordo com a legislação de Pólos Geradores de Tráfego - Lei $n^{\circ}$ 8.232/94.

Artigo $5^{\circ}$ - Poderá também ser autorizada a concessão do alvará de uso para edificações com áreas superiores a 250,00 $\mathrm{m}^{2}$ e para atividades ainda não contempladas na listagem da categoria de usos da Lei $n^{\circ} 6.031 / 88$, inclusive aquelas exercidas na própria residência, desde que as mesmas estejam de acordo com o disposto no artigo $2^{\circ}$ desta lei.

Artigo $6^{\circ}$ - A concessão de alvará de uso para as indústrias domésticas poderá ocorrer desde que:

a) a edificação e as construções acessórias a serem utilizadas para a moradia e o exercício da atividade tenham área igual ou inferior a 250,00 $m^{2}$ (duzentos e cinquenta metros quadrados);

b) a edificação não se localize em condomínios habitacionais;

c) a edificação não se localize nas zonas 04,08 e 18.

Parágrafo único - Na condição prevista neste artigo será dispensada a exigência da Lei de Pólos Geradores de Tráfego - Lei no 8.232/94, no que se refere às áreas de estacionamento.

Artigo $7^{\circ}$ - Consideram-se como domésticas as indústrias de pequeno porte, classificadas como micro empresas elou pequenas empresas e cujos responsáveis exerçam as atividades referentes na própria residência e suas edificações acessórias.

Parágrafo único - A indústria doméstica a ser admitida em áreas residenciais deverá apresentar ausência, ou quantidade desprezivel de poluentes do ar, da água e do solo e não poderá causar incomodidades, conforme definido no Artigo $3^{\circ}$ desta lei.

Artigo $8^{\circ}$ - A autorização de que trata o artigo $1^{\circ}$ desta lei nãa se aplica às áreas citadas na alínea "d" do inciso III do artigo 27 da Lei $n^{\circ} 6.031 / 88$, excetuando - se as seguintes áreas:

I - Jardim Guanabara;

II - Jardim Santa Genebra (parte I);

III - lotes confrontantes com as seguintes vias públicas:

a) Av. Moraes Salles, no trecho situado entre a Av. José Ferreira de Camargo e a Rua Piquete;

b) Av. Jesuino Marcondes Machado, no trecho situado entre a Rua Carolina P. Penteado e a Av. José Bonifácio;

c) Av. Mons. Jerônimo Baggio;

d) Av. José Bonifácio, no trecho situado entre a Rua Promissão e a Av.

Iguatemi;

e) Rua Castro Alves, no trecho situado entre a Av. Barão de Itapura e Av. Júlio Diniz;

IV - Jardim Flamboyant. 
Artigo $9^{\circ}$ - Para a concessão do alvará de uso deverá ser apresentada, por parte do interessado, uma declaração de não incomodidade, a qual, não sendo cumprida, implicará na cassação do respectivo alvará.

Artigo 10 - O alvará de uso será sempre concedido a título precário, e em caráter temporário, pelo prazo de 1 (um) ano, podendo ser cassado caso o responsável pela atividade licenciada passe a descumprir as exigências previstas nesta lei.

Artigo 11 - O alvará de uso poderá ser renovado por prazos iguais e sucessivos, desde que o responsável pela atividade licenciada não tenha descumprido as exigências previstas nesta lei.

Artigo 12 - Quando houver manifestação expressa da vizinhança contra a permanência da atividade no local, por motivo de incomodidade, será instaurado processo de averiguação que poderá resultar na cassação do alvará.

Artigo 13 - Os estabelecimentos que hoje abrigam atividades sem alvará de uso, e que se encontram em situação irregular, deverão enquadrar - se nas exigências constantes desta lei.

Parágrafo único - Os estabelecimentos irregulares terão 90 (noventa) dias de prazo para sua regularização, sob pena de fechamento e respectiva lacração.

Artigo 14 - $O$ controle da incomodidade será regulado pelas legislações federal, estadual e municipal, em especial a Lei $n^{\circ} 2.516 / 61$ e Decreto $n^{o}$ $5.441 / 78$.

Artigo 15 - Nos projetos habitacionais considerados pela Secretaria de Habitação elou COHAB - Campinas como sendo de Interesse Social permitir-se-ão os seguintes parâmetros construtivos:

a) Número de pavimentos: 5 (cinco) andares, incluído o térreo.

b) Isenção da obrigatoriedade da instalação de elevador.

c) Pé direito mínimo de $2,40 \mathrm{~m}$.

d) Número mínimo de vagas de estacionamento por unidade: 0,60.

e) Menor dimensão da área de serviço: $1,20 \mathrm{~m}$.

f) Um dormitório com um mínimo de 8,00 metros quadrados e o restante com um mínimo de 6,00 metros quadrados.

Parágrafo único - Os demais parâmetros de ocupação obedecerão as normas já estabelecidas nas legislações de Uso e Ocupação do Solo e no Código de Obras vigentes no município.

Artigo 16 - Nos conjuntos habitacionais de interesse social serão permitidos núcleos comerciais e de serviços.

Artigo 17 - Esta lei entra em vigor na data de sua publicação, revogadas as disposições em contrário.

Paço Municipal, 10 de janeiro de 1996.

\section{JOSÉ ROBERTO MAGALHÃES TEIXEIRA}

Prefeito Municipal

Autoria: Prefeitura Municipal de Campinas

Fonte: Biblioteca Jurídica da P.M.C.

Neste diploma, que serviu de base para as modificações posteriores, seguida pela Lei $n^{\circ} 10.566 / 2000$ e a Lei Complementar n62/2014, todas apresentando um conjunto de equívocos que se repetem, e que servem apenas como válvula de escape para as inadequações, já apontadas de um modelo de planejamento 
baseado, exclusivamente, no zoneamento, e no caso, de alto grau de restrição. Entre estes equívocos, podemos citar:

1. A restrição ao porte (Art. $4^{\circ}$, Inciso I, alínea a): ao fixar um porte máximo independentemente da demanda, e de fatores específicos do ramo de atividade (como necessidade de equipamentos e volume dos produtos), obriga o comerciante a procurar estratégias de como burlá-la, ajudado pela várias leis de anistia ("puxadinhos"), ou simplesmente ignorá-la dadas as deficiências de fiscalização. Ao consumidor, cujas necessidades e exigências mudam e se sofisticam com o desenvolvimento econômico e tecnológico não é dada opção, pois terá de se deslocar para satisfazer suas necessidades de consumo e abastecimento, na medida em que seus padrões de consumo também se alterarem;

2. A liberação de apenas algumas categorias de usos (Art. $4^{\circ}$, Inciso I, alínea b), supondo que as necessidades de consumo sejam estáticas ao longo do tempo;

3. A proteção aos bairros da elite com as exceções de praxe (Art. $8^{\circ}$ );

4. A porta aberta para os casuísmos e subjetividade do agente público (Artigos $5^{\circ}$, e $9^{\circ}$ ao $12^{\circ}$ );

5. O ato de aproveitar a oportunidade de uma nova lei para incluir assuntos diversos do objeto original, no caso a inclusão de parâmetros construtivos relativos à ocupação em empreendimentos de interesse social.

Em 2000 surge a Lei $n^{\circ} 10.566 / 00$ que apenas aumenta os trechos das áreas listadas na lei anterior, e abre a porta para a liberação geral ao agregar a figura da data do C.C.O. (Habite-se) como corte para a concessão do Alvará de Uso.

Deste modo, a situação pode ser resumida da seguinte maneira: se uma atividade comercial ou de serviços for exercida em um imóvel existente (com Habitese) anterior a 31/12/2000 a empresa poderá funcionar, mesmo que em um bairro zoneado como "estritamente residencial" (exceto nos chamados bairros protegidos pela já citada alínea d, que são moradia das classes mais abastadas). Porém, se o interessado em abrir um comércio ou escritório quiser edificar em um terreno vago um imóvel comercial para nele exercer a mesma atividade, esta obra e o uso não poderão ser autorizados, e assim se mantém o discurso de que está se preservando o caráter residencial unifamiliar daquela área. 
Como se passaram mais 14 anos e o poder público não conseguiu rever a legislação, e a data de 31/12/2000 não atende mais às necessidades das novas dinâmicas urbanas e econômicas de diversas áreas da cidade, em 20 de janeiro de 2014 é promulgada mais uma alteração, a Lei complementar n 62/2014 que revoga as anteriores e estende a possibilidade de Alvará de uso para outras áreas, diminui a restrição do porte e acaba por repetir alguns dos mesmos equívocos já citados, especialmente no que tange à questão do porte e à liberação de apenas determinadas categorias ou subcategorias.

Esta Lei Complementar possibilita a obtenção do Alvará para comércio e serviços em 6 dos bairros originalmente protegidos na alínea d) do Inc. III do Art.27 da Lei $6.031 / 88$, em todas as principais vias do município (as classificadas como Arteriais pela Lei do Polos Geradores de Tráfego - Lei $\left.n^{\circ} 8.232 / 94\right)$ e, em mais 113 vias do município, reconhecendo, finalmente, que os logradouros que tem como características grandes fluxos de pessoas e veículos, tendem a se tornar áreas atrativas ao comércio e serviços, independentemente do que a legislação estipular.

Ao intervir em alguns bairros protegidos cria a "exceção da exceção", não fazendo nada mais do que reconhecer (tardiamente) as mudanças na dinâmica urbana experimentada por estas áreas, e na verdade, por toda a cidade.

Além destas leis de caráter geral patrocinado pelo Executivo Municipal, até o advento do Plano Diretor de 2006 (Lei Complementar n¹5/06) era possível que vereadores propusessem alterações pontuais no zoneamento, numa relação que sempre motivou dúvidas quanto ao real motivo das alterações propostas, se no interesse de indivíduos ou grupos, ou se no interesse da cidade.

No período de 1988 até 2006 (quando a Promulgação do Plano Diretor - Lei Complementar n¹5/06 - estabelece que a prerrogativa de elaborar Leis de mudança de zoneamento é exclusiva do Poder Executivo, não podendo ser pontual e somente após estudos detalhados), pudemos identificar dezenas de leis específicas de alteração do Zoneamento, patrocinadas pelo Poder Legislativo (18 delas servindo de "guarda-chuvas" para diversas emendas), muitas delas com artigos alterando o zoneamento de um quarteirão apenas, ou até mesmo de um lote ou gleba singulares. Além destas, há uma expressiva quantidade (que não foi possível precisar) de alterações pontuais, propostas através de emendas à Projetos de Lei 
que versavam originalmente sobre outros assuntos.

Como paradigma deste modelo podemos citar a Lei $\mathrm{n}^{\circ} 11.764 / 04$ de autoria do vereador Sebastião dos Santos, e que recebeu diversas emendas de outros parlamentares num total de 34 alterações, algumas pontuais em um único imóvel, outras alterando praticamente bairros inteiros (vide Inciso XII).

Reproduzimos a seguir trechos desta lei que foi objeto posteriormente de ADIn (Ação Direta de Inconstitucionalidade) por parte do Ministério Público de São Paulo em $2008^{60}$, quando muitos empreendimentos e obras já haviam sido executados e empresas se estabelecido nestes locais.

Isto criou um grave problema de insegurança jurídica para os adquirentes e proprietários de imóveis, além dos empreendedores, e pondo em risco o funcionamento de empresas comerciais que adquiriram terrenos baseados em um zoneamento cuja validade estava sendo questionada, cinco anos após a publicação da sua alteração.

\section{LEI N 11.764 DE 25 DE NOVEMBRO DE 2003}

Art. $1^{\circ}$ - Ficam alterados os zoneamentos a seguir discriminados:

I - Todos os lotes com frente para a Av. Dr. Armando A. Ottaviano com códigos cartográficos $n .1100,1308,1327,1337,1345,1347,1356,1363$, 1374 da PRC 3162 e Códigos Cartográficos n. 3282, 3497 da PRC 3161, de $Z 3$ para $Z$ 9;

$[\ldots]$

XI - O lote L 009 SL, do quarteirão 03796 Quadra J, do loteamento Mansões Santo Antonio, de Z 4 para Z 13;

XII - Quarteirões 3229, 6410, 6390, 6371, 3204, 3185, 3155, 3137, 3357, 3130, 3350 e 2483, do Parque Rural Fazenda Santa Cândida, de Z 3 hachurado para Z $14 B G$;

[...]

XXVIII - lote 17 do quarteirão 1440 do Parque residencial Burato PRC 3234, de Z 3 BG para Z 11 BG;

[...]

XXXIV - lotes de 1 a 14 da quadra AM4 do Qt. 7981 PRC 324 de Z 3 para Z 7.

Art. $2^{o}$ - Esta lei entra em vigor na data de sua publicação.

Campinas, 25 de novembro de 2003. IZALENE TIENE

Prefeita Municipal Prot. 03/08/5009 autoria: Vereador Sebastião dos Santos

Fonte: Biblioteca Jurídica da P.M.C.

As restrições presentes na legislação refletem as expectativas dos

\footnotetext{
${ }^{60}$ (ADIn n $\left.^{\text {o }} 163.559-00 / 0-00\right)$, proposta pela 9 a Promotoria Pública (Promotoria de Urbanismo)
} 
proprietários quanto à utilização do zoneamento como resguardo contra possíveis prejuízos ao valor das propriedades pela presença de usos (e usuários) indesejáveis.

Por outro lado esta forma de alterá-la pontualmente garante que este valor se mantenha (no caso das leis de flexibilização) ou gere enormes ganhos para os beneficiários, pois na maioria das vezes significam mais do que alteração de usos, sendo o objetivo real a multiplicação do valor da terra pela mudança do Coeficiente de Aproveitamento que é consequência desta alteração.

Visando aprofundar esta discussão entre a legislação de uso e ocupação do solo da cidade de Campinas, as atividades terciárias, e seu rebatimento espacial, trouxemos como estudo de caso a ser detalhado o bairro da Nova Campinas, objeto do capítulo a seguir. 


\section{CAPÍTULO 4}

\section{1 - A Nova Campinas}

Em fins da década de 1930 o limite leste da mancha urbana do Município era o bairro do Cambuí, na altura da Rua Cel. Quirino. Entretanto, Prestes Maia em seu Plano de Melhoramentos Urbanos de Campinas aprovado em 1938, já previa a expansão do território com instalação de anéis concêntricos de avenidas perimetrais, conectados por vias radiais (Badaró, 1996), conforme já mencionado. Um trecho da perimetral externa cortaria parte do que hoje é a Nova Campinas, logo após o leito do córrego Proença, que deveria ser saneado e retificado.

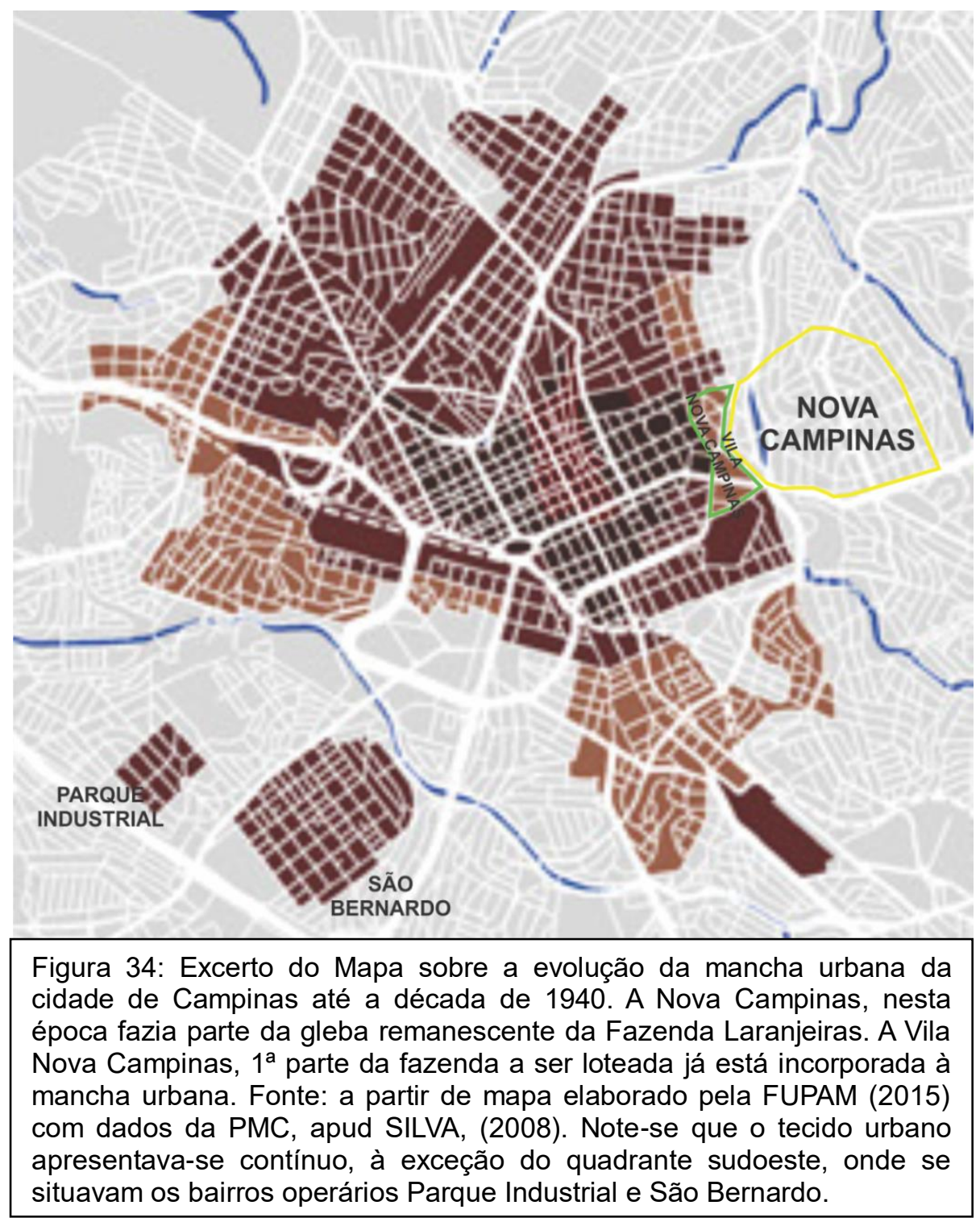




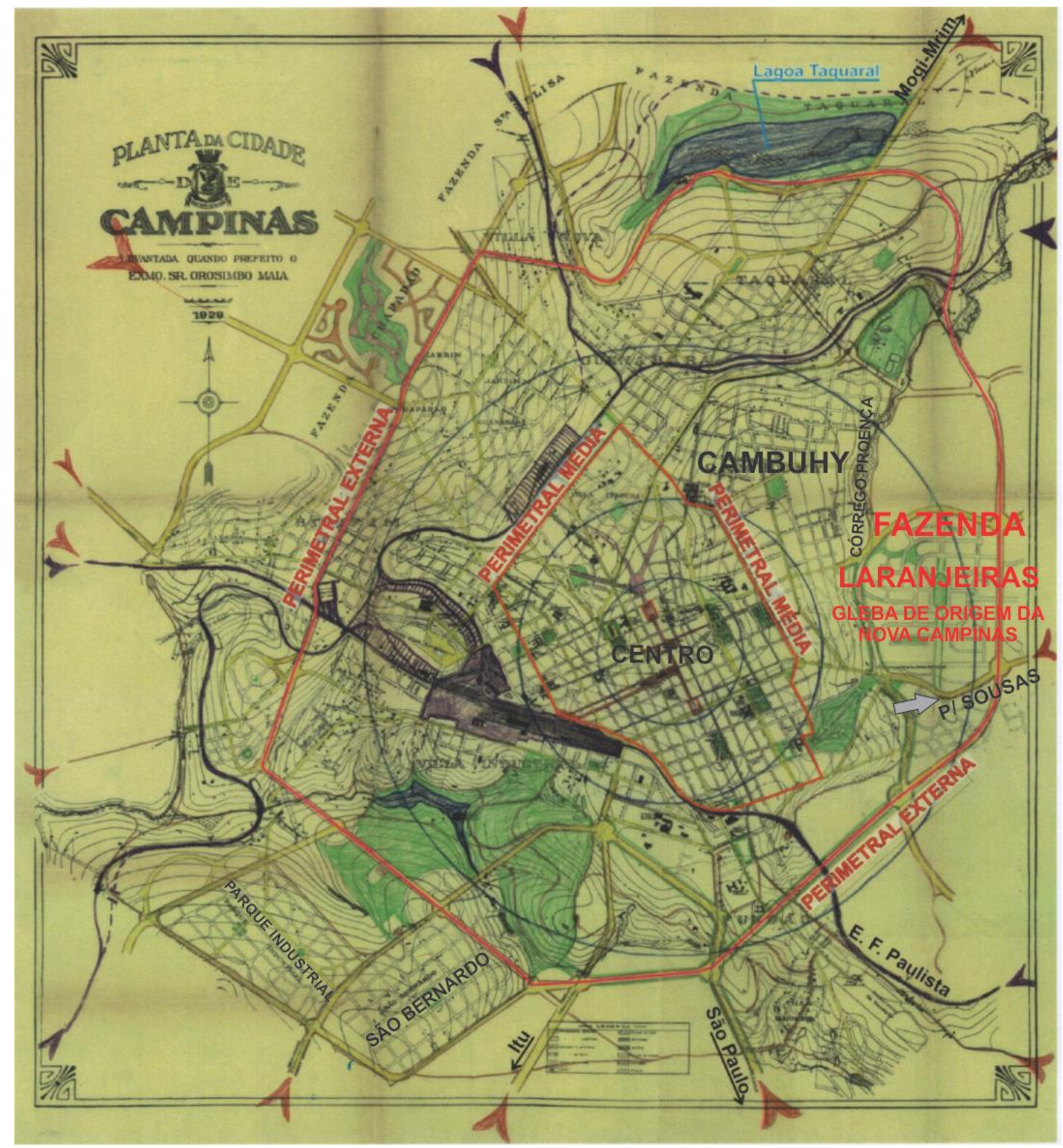

Figura 35: Avenidas perimetrais do Plano de Melhoramentos Urbanos de Prestes Maia de 1938, desenhado sobre a base de 1929. Fonte: a partir de BADARÓ (1996), com anotações nossas. Note-se que ainda não havia arruamento definido para as terras da Fazenda Laranjeiras, onde mais tarde seriam implantadas a Vila Nova Campinas e a Nova Campinas, motivo pelo qual Prestes Maia propõe um desenho "genérico". De qualquer modo pode-se dizer que o traçado da Perimetral Externa equivale, parcialmente, com o da Av. Dr. Jesuíno Marcondes Machado.

Após os limites do Cambuí se situava a Fazenda Laranjeiras, de propriedade do Cel. Francisco Andrade Coutinho e sua Esposa, Dona Alzira Ferreira Penteado 
Coutinho, neta de Joaquim Inácio Ferreira Penteado, Barão de Itatiba ${ }^{61}$.

Em 1939, uma parcela da gleba foi destacada e loteada com projeto do arruamento assinado pelo Eng. ${ }^{\circ}$ Civil Angelo Crosato, com o nome de Vila Nova Campinas, já com características semelhantes ao futuro loteamento que viria a ser a Nova Campinas, isto é, ruas e quarteirões com desenho sinuoso, seguindo a topografia natural, e com uma série de pequenas praças ajardinadas em pontos estratégicos, nas extremidades de alguns quarteirões, conforme pode se visualizar na figura abaixo:

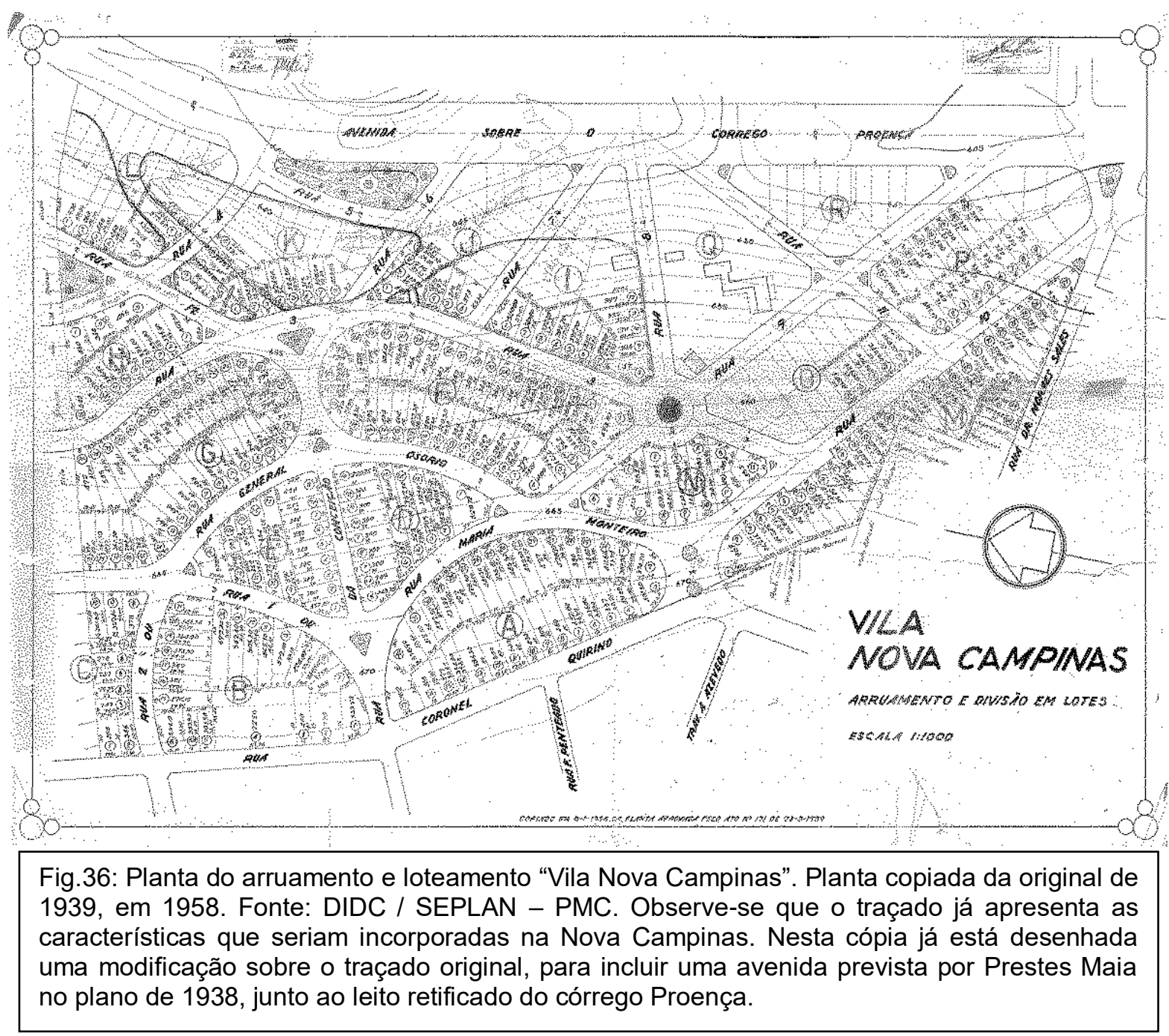

O responsável pela venda dos lotes foi o Sr. João Brásio, conhecido corretor da cidade. Brásio se envolveu não apenas na venda dos lotes da Nova campinas

\footnotetext{
${ }^{61}$ Ferreira Penteado, empresário e cafeicultor recebeu o título de "Barão de Itatiba" em 1882 em reconhecimento pelas suas obras benemerentes. Proprietário de grandes extensões de terra em Campinas, foi responsável pela edificação do Palácio dos Azulejos, concluído em 1878 e tombado pelo CONDEPACC, CONDEPHAAT e IPHAN. Fonte: CSPC / CONDEPACC.
} 
como também no desenvolvimento de estratégias para a ocupação de um loteamento que estava naquele momento, situado nos limites da área urbanizada, conforme se pôde visualizar na figura 34, e sua futura incorporação na mancha urbana. Na década de 50, constituiu empresa incorporadora em sociedade com a família Coutinho, que viria a se chamar "COBRÁS" e tinha a finalidade de construir residências destinadas a atrair moradores para o loteamento ${ }^{62}$.

Com o sucesso alcançado na primeira etapa de vendas em 1944 (portanto, ainda antes do fim da II Guerra) foram colocados à venda os 100 lotes remanescentes da "Vila Nova Campinas", que assim se denominava para marcar uma diferenciação em relação à "Campinas Velha". Reportagem no Correio Popular de 26/03/1944 chamava atenção para o fato aclamando o arruamento como:

"[...] a pequena "Cidade Jardim" em que se transformou a antiga chácara Laranjeira da Exma. Sra. D. Alzira Ferreira Coutinho.

Há menos de dez anos entre o Cambuí em plena Evolução e a Campinas Velha, quase decrépita, a chácara "Laranjeira", cercada de muros de Taipa, à antiga, era uma reminiscência verde de antiga e sossegada fazenda senhorial, beirando ao longo da Rua Coronel Quirino.

Por sinal que mesmo fronteiro à Rua Ferreira Penteado, lá no alto, no portão largo, sob a guarda de leões louçados, é que dava entrada À Chácara Laranjeira, enquanto a Rua Conceição, visinha era interrompida por aqueles muros de taipa[...].

Proprietária da chácara, a veneranda senhora d. Alzira Ferreira Coutinho, viúva do saudoso Coronel Francisco Andrade Coutinho, um nome de projeção nos fastos da cidade, não quis por mais tempo pôr entrave ao progresso crescente da "Princesa d'Oeste". Cedeu um dia, para a cidade nova, retalhos daquele verde amplo da "laranjeira" que dividido em lotes se transformaram num repente na então diminuta "Nova Campinas, com os seus primeiros "bungalows" e as suas primeiras ruas, traçadas em caprichosas curvas pela Diretoria de Obras, como um bairro diferente, único entre os demais que possuímos.

Confiada a venda ao conceituado e estimado corretor, Sr. João

\footnotetext{
${ }^{62}$ Dados fornecidos ao autor pela filha e netos do Sr. João Brásio em entrevistas. Segundo a família, Brásio esteve envolvido com o bairro por toda a sua vida, vindo a falecer em 1977. Nas Fichas de Habite-se foram localizados diversos imóveis cuja propriedade ou autoria de projeto está relacionada à famila Brásio, à COBRÁS, Ltda., ou ao Eng. ${ }^{\circ}$ Sylvio de Andrade Coutinho Filho, sócio da empresa, e neto de D. Alzira Andrade Coutinho.
} 
Brásio, dentro em pouco era preciso alargar a área da Nova Campinas, com mais um pedaço da Chácara Laranjeira, tal a procura, verdadeira disputa dos lotes disponiveis no aprazivel logradouro(...)

Assim, já não é um simples bairro, mas uma pequena e ajardinada cidade, o que traduz a Vila Nova Campinas, colorido cartão de visita da esplendida e moderna Princesa d'Oeste(...)".

Correio Popular de 26 de março de 1944, p.8. Fonte: CEDOC / RAC

Na esteira deste boom imobiliário, o loteamento Nova Campinas foi aprovado em 02/04/1946 por Decreto ${ }^{63}$ assinado pelo então Prefeito Municipal Joaquim de Castro Tibiriçá identificando a área a ser arruada e loteada como "parte da Chácara das Laranjeiras, à margem direita do córrego Proença de propriedade da Companhia Imobiliária Nova Campinas e parte do arruamento de Nova Campinas (aqui, se referindo às áreas ainda não divididas em lotes da Vila Nova Campinas), de Propriedade de Dona Alzira Ferreira Coutinho".

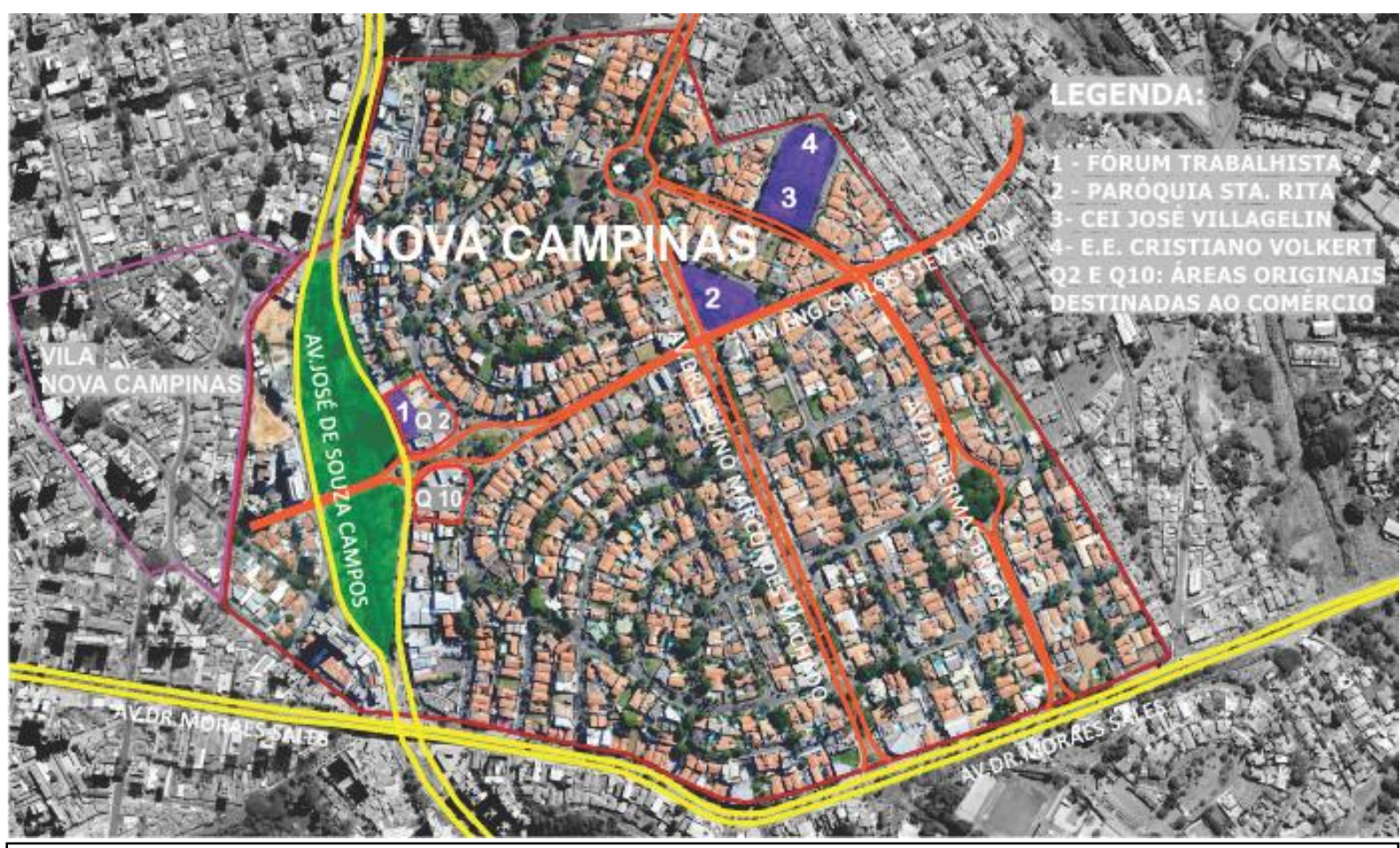

Fig. 37: A Nova Campinas e a Vila Nova Campinas em imagem atual (2014). Fonte: A partir de imagem do Google Earth Pro.

O Decreto classificava o arruamento como "residencial", ainda que previsse um pequeno núcleo comercial restrito a atividades de suporte local, situado nas

\footnotetext{
${ }^{63}$ Decreto no $^{\circ} 121$ de 02/01/1946. Fonte: Coordenadoria Setorial de Documentação/ Biblioteca Jurídica da Prefeitura Municipal de Campinas.
} 
extremidades das quadras $\mathrm{n}^{\mathrm{os}} 02$ e 10. (figura 37)

Projeto do Eng. ${ }^{\circ}$ formado pela Escola Politécnica, Jorge de Macedo Vieira, que trabalhou no início de sua carreira na Cia. City, o arruamento seguia as linhas originais de seu predecessor, a Vila nova Campinas incorporando alguns elementos comuns aos empreendimentos paulistanos da Cia. City, com referências ao urbanismo inglês das cidades-jardim.

Trazia como diferencial (algo não muito comum para a época), a instituição de parâmetros urbanísticos bem definidos em relação a recuos (5m para as ruas medindo 12 a 15m de largura e $6 \mathrm{~m}$ para as ruas com 16 a $20 \mathrm{~m}$ de largura e $8 \mathrm{~m}$ na Av. Perimetral), afastamentos ( $8 \mathrm{~m}$, na época denominava-se "recuo de fundos") e construção de dependências, as quais somente seriam permitidas nos afastamentos de fundos. As taxas de ocupação máximas seriam de 1/3 da área do lote para os lotes, com exceção do núcleo comercial (onde esta taxa poderia atingir 60\%). Também proibia "quaisquer tipo de fechos no alinhamento, assim como nas divisas laterais, nos trechos compreendidos entre o alinhamento e a frente dos prédios".

O referido decreto de aprovação previa ainda a construção de uma escola na quadra $n^{\circ} 29$ (hoje ocupada pela Escola Municipal EMEF José Villagelin Neto e pela Escola Estadual Cristiano Volkert), sendo os proprietários compensados com uma área livre junto estrada de Sousas (atual Av. Dr. Moraes Salles). Também se previu a construção de um templo (igreja católica) na praça situada entre as Ruas 31, 18 e a Avenida 2, e que é a Paróquia de Santa Rita de Cássia.

Este Decreto também obrigava os "proprietários" (se referindo aos empreendedores, pois à época a lei não fazia esta distinção) a drenar os terrenos pantanosos e alagadiços e também a executar todo o sistema de drenagem de águas pluviais nas ruas e praças.

O loteamento se dividia claramente em duas partes, sendo a menor situada à margem direita do córrego Proença, fazendo divisa com a Vila Nova Campinas e o bairro do Cambuí. Separando-a do restante do loteamento, havia uma avenida prevista no plano de melhoramentos urbanos de Prestes Maia, que é hoje a Av. José de Sousa Campos, conhecida como Via Norte-sul. Neste trecho, se alargava com suas duas pistas separadas pelo córrego retificado e por uma praça/parque linear muito arborizado que protege e contribui para a drenagem deste fundo de vale. Esta 
avenida se conectava com a Perimetral externa do Plano de Prestes Maia, cujo traçado, nesta região equivaleria parcialmente à Av. Jesuíno Marcondes Machado(comparar figuras 34 e 36 ).

A parcela do loteamento situada na sua margem esquerda começa a ser ocupada já na década de 50 (tabela 4) e assume rapidamente, até mesmo por questão de contiguidade, as feições do Bairro do Cambuí (repetindo o que aconteceu com a predecessora Vila Nova Campinas) ainda que se diferencie pelo seu traçado sinuoso, ao contrário do Cambuí que foi arruado em malha reticulada.

Ao pesquisar as Fichas de Habite-se do Cadastro Municipal da Rua Eng. ${ }^{\circ}$ Carlos Stevenson pode-se constatar que neste trecho inicial (situado à margem esquerda do córrego Proença) as datas de Habite-se variam entre 1950 e 1963. É interessante notar a anotação na ficha do imóvel situado no n56 que classifica o arruamento como “CAMBUÍ - quadra "Q" - NOVA CAMPINAS”. Mais que isto, neste documento está registrada toda uma discussão sobre quais os parâmetros que deveriam ser adotados (no caso a discussão diz respeito a padrão de afastamento das divisas), opinando o responsável pela adoção de critérios iguais aos do Cambuí nesta parte do arruamento, e isto já em 1956.

Outro dado interessante que se pode identificar nestas fichas é a confirmação da atuação das famílias Brásio e Coutinho na construção de imóveis para atrair moradores para o loteamento: 0 imóvel $\mathrm{n}^{\circ} 82$ têm como proprietário, autor do projeto e responsável técnico o Eng. ${ }^{\circ}$ Sylvio de Andrade Coutinho Filho e o de $\mathrm{n}^{\circ} 96$ consta como proprietário a COBRÁS, Soc. Imob. Const. e Com. Ltda., constando inicialmente Vanderlei Brásio como autor e depois, numa substituição de plantas, o Eng. ${ }^{\circ}$ Sylvio de Andrade Coutinho Filho. 


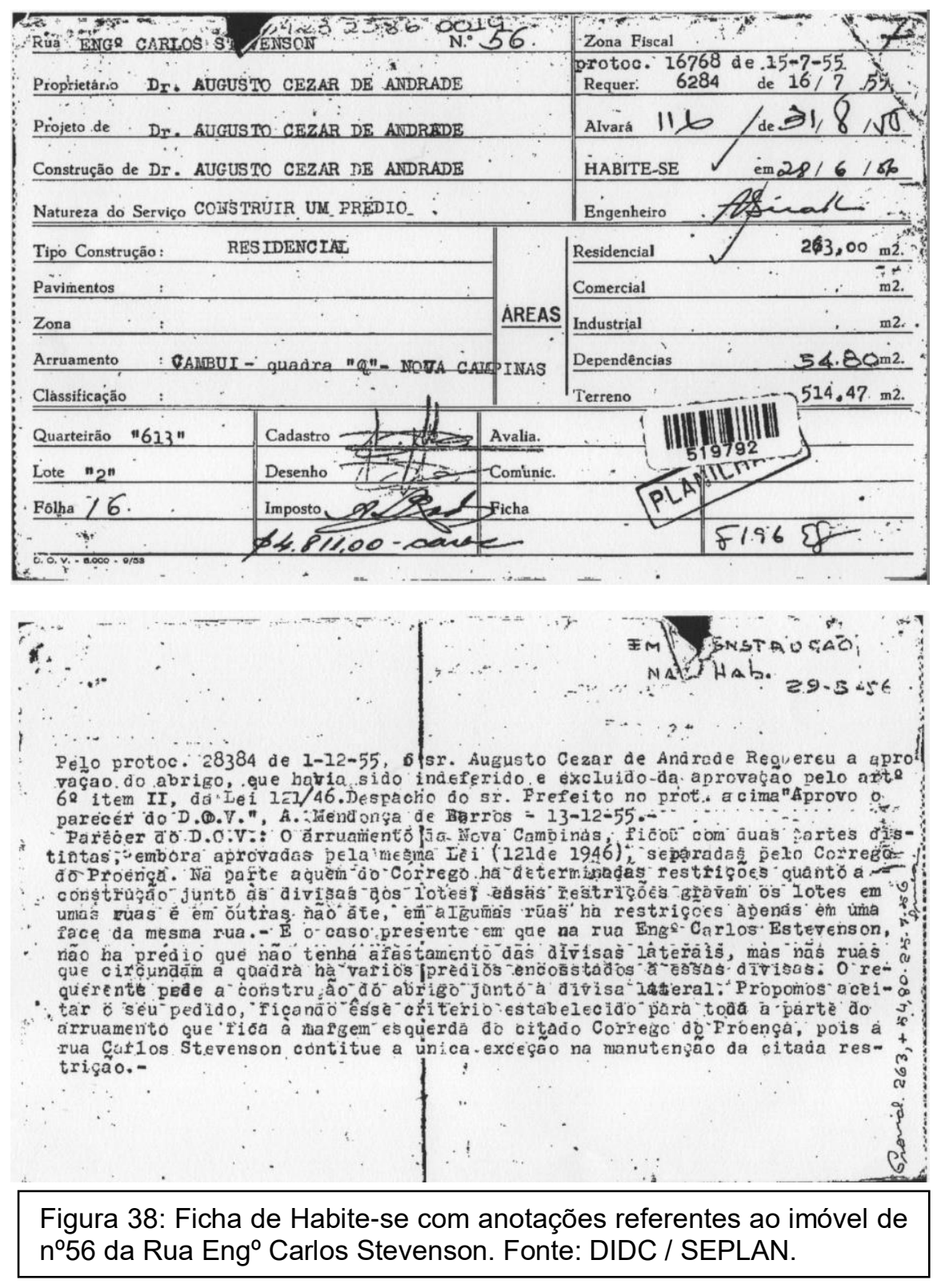

Tabela 4: Ocupação dos imóveis da Rua Eng. ${ }^{\circ}$ Carlos Stevenson, no trecho situado à margem esquerda do córrego Proença.

\begin{tabular}{ccccc}
\hline $\mathrm{N}^{\circ}$ do imóvel & Data do Alvará & Data do Habite-se & Área do lote $\left(\mathrm{m}^{2}\right)$ & Área Construída $\left(\mathrm{m}^{2}\right)$ \\
\hline 56 & $31 / 08 / 55$ & $28 / 06 / 56$ & 514,47 & 263,00 \\
66 & $02 / 04 / 50$ & $26 / 12 / 51$ & 668,00 & 310,30 \\
79 & $12 / 06 / 61$ & $27 / 05 / 63$ & 813,00 & 456,50 \\
82 & $26 / 04 / 50$ & $01 / 12 / 50$ & 495,00 & 223,00 \\
96 & $09 / 10 / 51$ & $19 / 05 / 54$ & 587,00 & 194,00 \\
105 & $13 / 02 / 62$ & $01 / 06 / 65$ & 1258,00 & 449,00 \\
\hline
\end{tabular}

FONTE: Fichas Cadastrais DIDC/SEPLAN 
Já no trecho da via que fica na margem direita do córrego Proença, foram analisados 55 imóveis e há uma maior distribuição das datas de Habite-se entre as décadas de 1950 (16 móveis), 1960 (20 imóveis) e 1970 (17 imóveis) e até 1980 (2 imóveis). Não foram encontrados imóveis com Alvará ou Habite-se expedido na década de 1990 (Fig. 38):

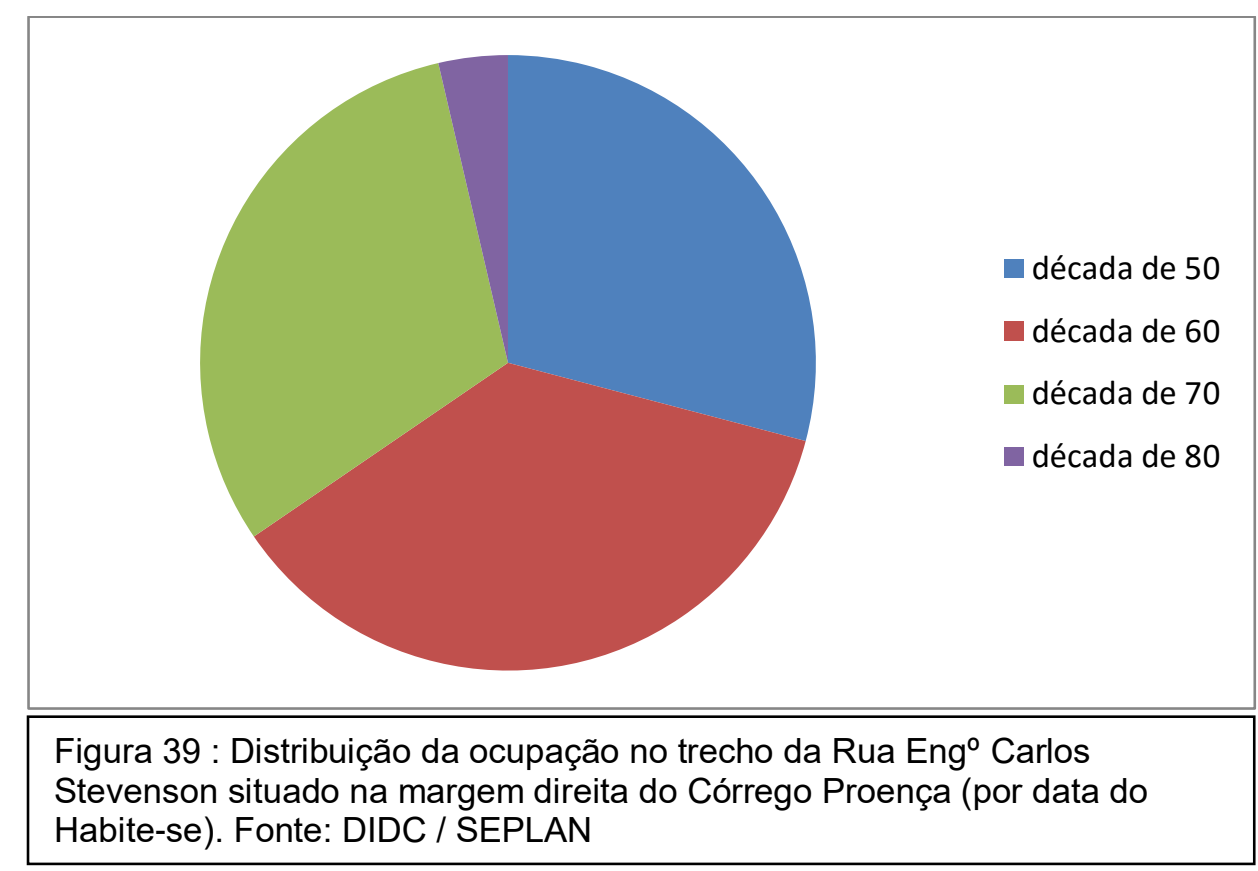

Outra informação interessante colhida junto a moradores antigos e exmoradores é que até o fim da década de 1960, na margem direita do Proença somente as três vias principais do bairro eram asfaltadas: Rua Eng. ${ }^{\circ}$ Carlos Stevenson, R. Dr. Hermas Braga e Av. Dr. Jesuíno Marcondes Machado.

Comparativamente, na R. Dr. Hermas Braga a distribuição temporal da ocupação apresente um perfil um pouco diferente da rua Eng. ${ }^{\circ}$ Carlos Stevenson, com a ocupação mais concentrada na década de 1960 (30 imóveis) e 1970 (36 imóveis), pequeno número nos anos iniciais na década de 1950 (6 imóveis) e na década de 1980 (7 imóveis). Nenhum é edificado nos anos 90 e apenas 1 nos anos 2000 , apesar de ainda existirem dois lotes vagos, conforme levantamento de usos em fevereiro de 2015. Também não identificamos nenhuma reforma com habite-se posterior à década de 1980, o que indica que apesar de a maioria dos imóveis ter passado por reforma com transformação de uso para comercial, não houve acréscimo de área construída (Fig. 39). 


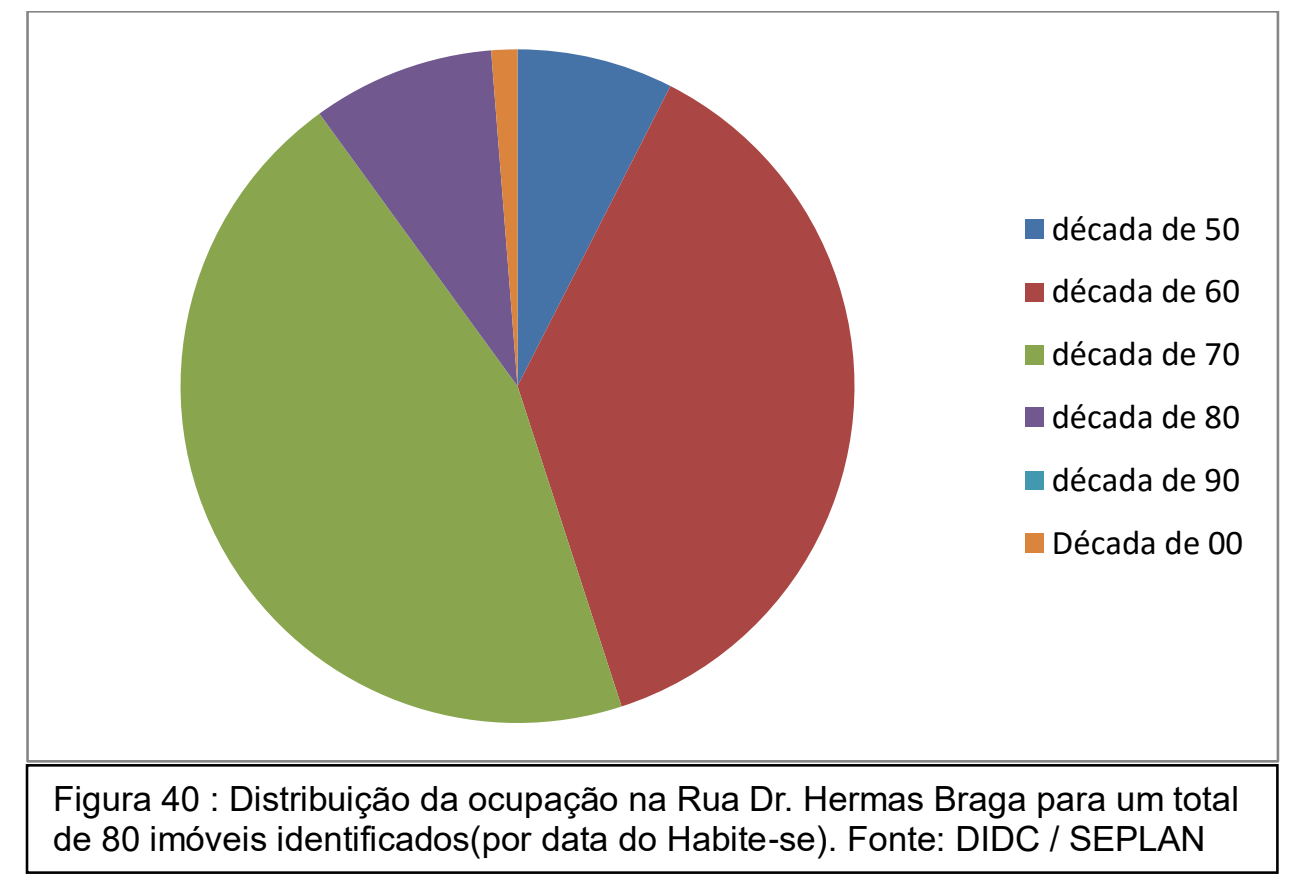

A Campinas que viu o nascimento do bairro é muito diferente da cidade atual: Em 1940, Campinas contava com 129.940 hab., ao passo que em 2010 são 1.074.023 hab. As taxas de crescimento populacional, com pico nos anos 60 e 70, entretanto arrefecem a partir de 1980, sendo a média de 2010 apenas pouco mais de1/3 da década de 1960, conforme mostrado na tabela 5 :

\begin{tabular}{|c|c|c|c|c|c|c|c|c|}
\hline $\mathbf{N}^{\circ}$ do imóvel & 1940 & 1950 & 1960 & 1970 & 1980 & 1991 & 2000 & 2010 \\
\hline BRASIL & 41.236.315 & 51.944 .397 & 70.992 .343 & 93.165 .565 & 119.002 .706 & 146.825 .475 & 169.799.170 & 190.755 .799 \\
\hline TGCA $\%$ & 1,49 & 2,39 & 2,99 & 2,89 & 2,48 & 1,93 & 1,64 & 1,17 \\
\hline R. Sudeste & 18.345 .831 & 22.548 .494 & 31.062 .978 & 39.853 .498 & 51.134 .125 & 62.740 .701 & 72.297 .351 & 80.364 .410 \\
\hline TGCA $\%$ & & 2,08 & 3,26 & 2,52 & 2,64 & 1,77 & 1,62 & 1,05 \\
\hline $\begin{array}{c}\text { Est. São } \\
\text { Paulo }\end{array}$ & 7.180 .316 & 9.134 .423 & 12.974 .699 & 17.771.948 & 25.040 .712 & 31.588 .925 & 37.032 .403 & 41.262 .199 \\
\hline TGCA $\%$ & & 2,44 & 3,57 & 3,20 & 3,49 & 2,13 & 1,78 & 1,08 \\
\hline $\begin{array}{l}\text { R. Gov. de } \\
\text { Campinas }\end{array}$ & 265.765 & 309.423 & 484.672 & 770.497 & 1.407 .236 & 2.033 .173 & 2.338 .148 & 2.797.137 \\
\hline TGCA \% & & 1,53 & 4,59 & 4,74 & 6,49 & 3,51 & 2,54 & 1,47 \\
\hline Campinas & 129.940 & 152.547 & 219.303 & 375.864 & 664.559 & 847.595 & 969.396 & 1.074 .023 \\
\hline TGCA $\%$ & & 1,61 & 3,70 & 5,54 & 5,86 & 2,24 & 1,50 & 1,09 \\
\hline
\end{tabular}

FONTE: Fontes: IBGE 1940-2010; PMC, 1998 e 2006. NEPO/UNICAMP, 2006. Elaboração: FUPAM, 2015

A partir da década de 50 com a implantação da indústria automobilística e do plano de metas de Juscelino Kubitschek o país entra na segunda fase de industrialização. A cidade de Campinas atrai muitas indústrias multinacionais nesta 
época, como Bosch, Clark, GE, Bendix, Dunlop, BF Goodrich, Ashland, Merck, Rigesa, Wabco, além de outras dos setores metalúrgico, químico, papel, etc.

Nas décadas de 1960 e 1980 acelera-se o crescimento da cidade que atingiria 664.559 hab. em 1980, com taxas anuais superiores a 5,5\% entre 70 e 80 .

O crescimento expressivo da cidade com a industrialização, e as estratégias para atrair moradores (como a construção de casas para venda) começam a dar resultados. Há um grande incremento na demanda por moradias de todos os padrões, o que também ocorre nas camadas mais altas.

Muitos estrangeiros que vieram residir na cidade elegem a Nova Campinas, ainda com disponibilidade de lotes, como local de moradia, a ponto de uma reportagem do Correio popular de 1983, classificar o bairro como uma "pequena ONU”. Esta mesma reportagem informava que:

"no princípio: o bairro cresceu lentamente, pois os lotes eram caros e seus pretensos compradores pensavam mais em investir dinheiro, do que em construir para morar. Não havia nada no bairro que nascia com muita timidez... Houve depois o famoso "Crime do Citroën", o crime do "Bandido Mascarado" que espantou ainda mais os primeiros habitantes. Um filipino foi o primeiro a construir sua casa no novo bairro, depois a família Trabulsi e foi assim, pingando pouco a pouco que o bairro cresceu”. (...)

O bairro da Nova Campinas é internacional no campo de moradores. Nele, em belas mansões residem chineses, como a tradicional e aristocrática família Sieh, da Minasa, japoneses da Fazenda Monte D'Este, indianos, suiços, belgas, franceses, italianos, norte-americanos, portugueses, filipinos, árabes, judeus, todos convivendo numa grande harmonia. São quase todos proprietários ou presidentes de indústrias multinacionais ${ }^{64}$.

Esta reportagem sobre o perfil do bairro (ou pelo menos sobre a imagem que a cidade dele tem) permite concluir que, inicialmente houve certa resistência da elite campineira em ocupar o bairro, o que explica as estratégias dos empreendedores em construir e ofertar residências para atrair moradores. Foi necessário que um

\footnotetext{
${ }^{64}$ Fonte: Jornal Correio Popular. 06/05/1983,pg.19
} 
estrangeiro rompesse o preconceito e se mudasse para o loteamento, então ermo, para que a percepção das elites locais se modificasse ${ }^{65}$.

A mesma reportagem nos dá uma pista sobre um dos fatores que viria a contribuir para o declínio do bairro após o seu apogeu, de meados da década de 70 a meados da década de 80 :

"[...] Assim é a Nova Campinas que, por ser considerado um bairro de ricos, é vítima de muitos assaltos à residências. Eis porque, a maioria de seus moradores possuem guarda-de-segurança, rígido controle para abrir seus portões, altos muros protetores e ferozes cães de guarda e, com a colaboração de todos, é constante, à noite o vai-e-vem das viaturas da Guarda-Noturna, na vigília do sossego e do bem-estar de todos".
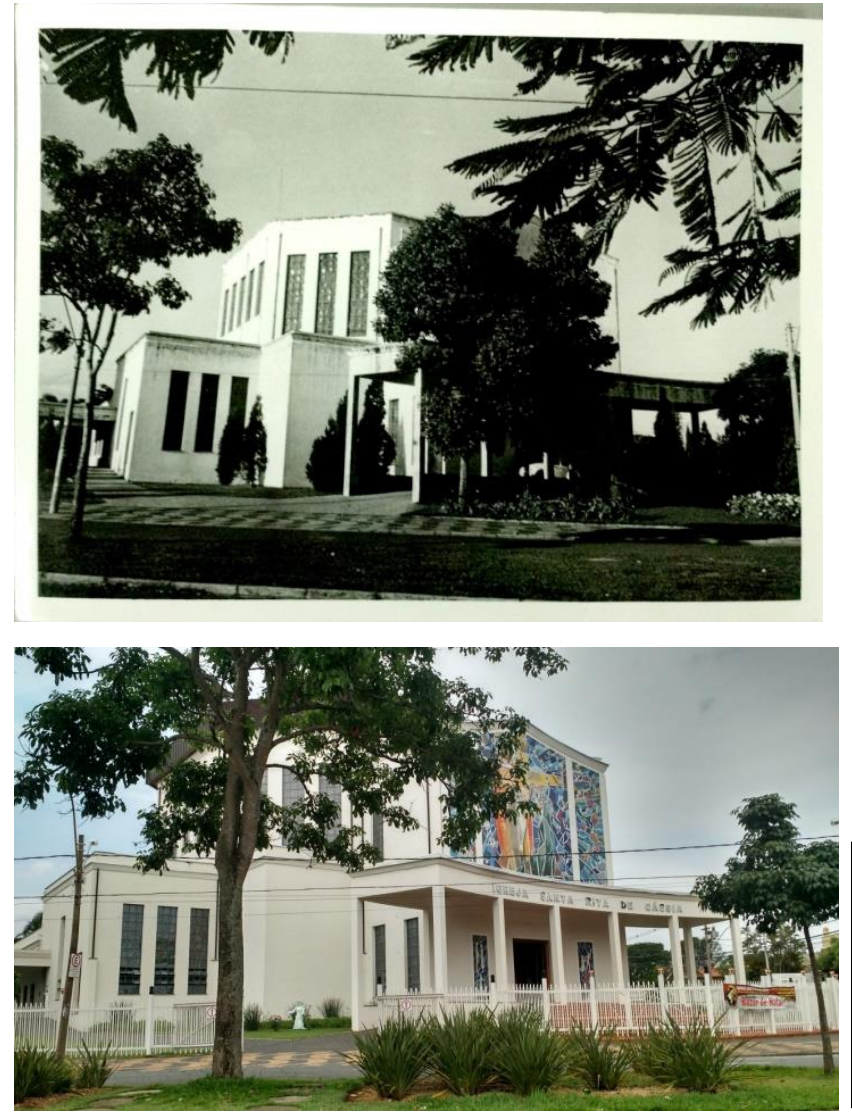

Figuras 41 e 42: Fotos de 1983 e atual da Igreja Santa Rita de Cássia, esquina da Av. Jesuíno Marcondes Machado com a Rua Eng. ${ }^{\circ}$ Carlos Stevenson. Fontes: Arquivo CEDOC/ RAC e acervo do autor.

\footnotetext{
${ }^{65}$ Nas Fichas de Habite-se, encontramos além dos nomes estrangeiros, empresários e executivos de multinacionais citados, vários nomes de profissionais com grande relevo na cidade de Campinas, especialmente nas áreas das Ciências Médicas e do Direito.
} 


\section{2 - O ocaso residencial e a ascensão do terciário a partir de 1980:}

São enormes as mudanças econômicas, sociais e culturais que modificaram os padrões de moradia das elites no último quartel do século $X X$ em várias cidades brasileiras.

No caso específico da Nova Campinas, entre os diversos fatores que contribuíram para sua decadência como locus privilegiado de moradia da elite campineira a partir de meados da década de 1980, identificamos cinco que, agindo de modo contínuo e entrelaçado, entendemos ter grande relevância:

- O aumento nos indicadores de violência urbana;

- A consolidação do modelo de loteamentos e condomínios fechados como modelo de moradia na alta renda;

- A mudança no eixo econômico do centro para a Via D.Pedro I;

- As alterações de perfil demográfico;

- As intervenções viárias nas principais vias lindeiras com forte aumento de fluxos, decorrentes do crescimento acelerado da cidade.

O efeito do aumento dos índices de violência urbana (frequentemente indicado como principal explicação para o sucesso dos condomínios e loteamentos fechados), ainda que não justifique ${ }^{66}$ a decadência de bairros residenciais tradicionais, não pode ser desprezado.

As causas do aumento nos índices de criminalidade nas grandes cidades comportam várias explicações que não cabe aqui discutir. Entretanto, é preciso recordar que Campinas passou por momentos críticos no aumento da violência urbana, a partir do final dos anos 80 , com grande repercussão na mídia inclusive nacional.

A posição da cidade e da Região Metropolitana como entroncamento de diversas rodovias, contribuiu fortemente para o aumento das ocorrências de roubo de cargas e veículos, bem como rota do tráfico nacional e internacional de drogas.

Reportagem do Jornal Correio Popular de 27/11/1994 trazia como manchete:

\footnotetext{
${ }^{66}$ Afinal, a suposta segurança proporcionada por estes enclaves é apenas relativa: são conhecidos os diversos casos em que bandos fortemente armados e bem organizados invadem residências em condomínios ou loteamentos fechados, sem tomar conhecimento dos aparatos de segurança.
} 
"Paranóia da violência encarcera população", destacando o aumento na procura por grades, alarmes e sistemas de segurança e indicando que nos condomínios fechados (a reportagem, como acontece quase sempre, não diferencia condomínios de loteamentos) o aparato de segurança toma proporções quase paramilitares. Também mostra um dado coletado pelo NEPO da UNICAMP que é no mínimo curioso: entre 1985 e 1993, período que viu as taxas de crescimento demográfico de Campinas decrescer para níveis inferiores a $2 \%$ ao ano, a criminalidade teve um aumento de $64,8 \%$ segundo dados de boletins de ocorrência no período.

Outra reportagem, do mesmo jornal, de 05/11/1995 que aponta para os vários assaltos a residências e a sensação de insegurança vivida na Nova Campinas e é ilustrada por uma foto mostrando uma guarita de segurança sobre o passeio tendo ao lado uma viatura de vigilância particular da época, que reproduzimos abaixo (Figura 43):

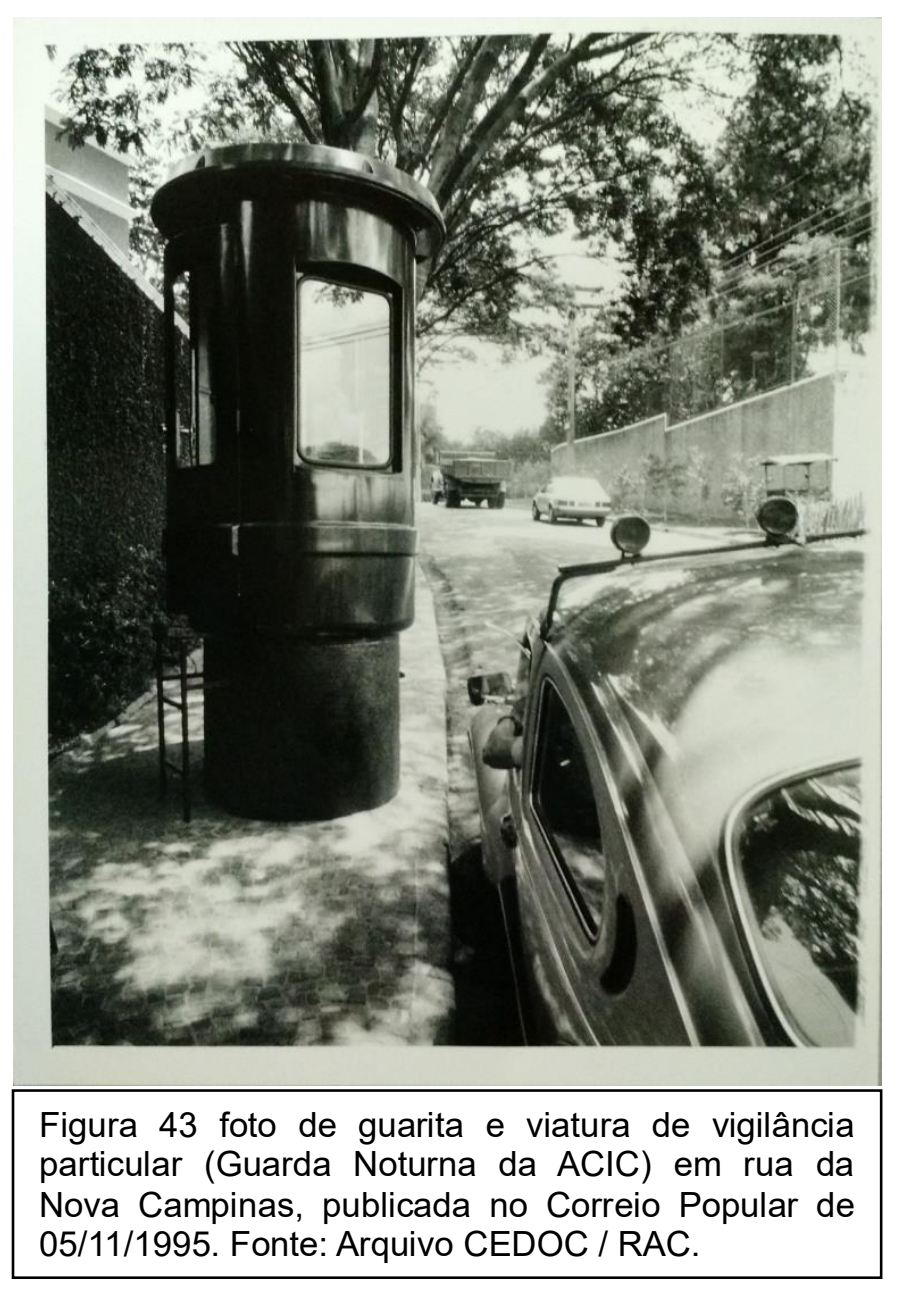


No início da década de $2000^{67}$, Campinas passa por outro grande surto de violência, cujo maior expoente é o bando de Wanderson Nilton de Paula Lima, o "Andinho", responsável por diversos assaltos, sequestros e inclusive implicado (de acordo com investigações) na morte do então prefeito Toninho do PT, em 10/11/2001. A escalada da violência repercutiu em diversos meios de comunicação sendo citada em reportagens nos programas televisivos de alcance nacional. Até periódicos regionais de outras regiões como o diário do Grande $A B C^{68}$ repercutiam o fato de que em 1999 o índice de homicídios superou os de São Paulo e Rio de Janeiro:

“Até há pouco tempo considerada um oásis no interior do Estado de São Paulo, Campinas, a 90 quilometros da capital, é hoje uma das cidades mais violentas do Brasil. Proporcionalmente ao número de habitantes, mata-se mais gente em Campinas do que em São Paulo ou no Rio de Janeiro.

Em 99, a taxa de homicídios em Campinas ficou em 55,8 por 100 mil habitantes. Em São Paulo, este índice foi de 55 e, no Rio, de 49. A cidade mais violenta do Brasil, por este critério, é Vitória (ES), com 77 homicídios por 100 mil habitantes [...]".

Durante entrevistas com moradores antigos do bairro foi citado que durante este surto do início dos anos 2000, uma espécie de temor coletivo se espalhou na população da cidade e atingiu com intensidade especial a Nova Campinas. Além do fato de concentrar moradores de alta renda, alvos preferenciais de sequestradores, havia então um motivo específico: as raízes do bando de Andinho estavam ligadas a bairros próximos, como as favelas dos Jardins Paranapanema e São Fernando, origem de grande parte dos trabalhadores domésticos das residências da Nova Campinas, o que contribuiu para uma onda de boatos e reforçar a sensação de insegurança generalizada entre os moradores do bairro ${ }^{69}$.

\footnotetext{
${ }^{67}$ Reportagem do Jornal Correio Popular publicada em 26/07/2000 sobre a polêmica Lei $\mathrm{n}^{\circ} 10.566 / 00$ que autorizava atividades comerciais em 2 vias internas ao bairro indicava que os moradores aguardavam resposta da Prefeitura a três protocolados solicitando a transformação do Bairro em Condomínio Fechado (sic), aproveitando a Lei de Bolsões residenciais, então em vigor.

${ }_{68}$ Reportagem no Diário do Grande ABC, de 21/04/2000. Fonte: www.dgabc.com.br/ Noticia/153162/, acessado em $22 / 08 / 2015$.

${ }^{69}$ Nestas entrevistas, vários ex-moradores afirmaram que este surto de violência do início da década de 2000 contribuiu fortemente para que um grande contingente de moradores se mudasse e/ou desistisse de lutar para manter o uso residencial exclusivo, conforme previsto na LUOS.
} 
Iniciando-se ainda nos anos 70, um novo fenômeno começou a modificar o modelo de expansão urbana do Município de Campinas, até então calcado nos loteamentos que distendiam o perímetro urbano: a consolidação dos condomínios e loteamentos fechados, inicialmente num processo que atinge o topo da pirâmide de renda e que depois, com o sucesso imobiliário, seria replicado até em bairros de classe média baixa.

Silva (2008) fez um extenso levantamento deste fenômeno e como ele interferiu no modelo de urbanização de Campinas a partir de 1970. Analisando um recorte temporal que cobre o período de 1970 a 2005, esta autora identifica que apesar de existirem outras áreas do Município onde há ocorrência de condomínios e loteamentos fechados, o eixo da Rodovia D. Pedro I concentra as cinco principais áreas de ocorrência deste modelo de urbanização, e neste caso sempre voltado às rendas média-alta e alta: Gramado, Sousas, Barão Geraldo, Taquaral e Alphaville.

Silva (2008) demonstra que as principais estratégias do marketing imobiliário para "vender" estas áreas envolvem slogans que enfocam a questão da segurança ("vida de chácara e segurança de apartamento", por ex.), proximidade a empreendimentos comerciais de grande porte, como o Shopping Iguatemi, ou Carrefour D. Pedro, ou até mesmo a vizinhança de outros condomínios e loteamentos de alto padrão, já consolidados, como na região do Gramado.

Um ponto que talvez devesse receber maior atenção se refere ao zoneamento proposto para estas regiões a partir do advento da LUOS em 1988. Em nosso entendimento, os padrões de zoneamento adotados, também tem contribuído para a concentração deste tipo de urbanização nestas regiões, zoneando-as como Z-4 ou Z-4BG e assim estabelecendo lotes e frações ideais mínimos com $500 \mathrm{~m}^{2}$ ou $1.000 \mathrm{~m}^{2}$ e, portanto, uma baixíssima densidade de ocupação. Mesmo nas áreas zoneadas como Z-3 ou Z-3BG, destas regiões, são raros os empreendimentos que propõem lotes de $250,00 \mathrm{~m}^{2}$, área mínima de lote para Z-3 (ainda que alguns condomínios fechados utilizem a fração mínima para propor um maior adensamento, visando maximizar o retorno dos capitais investidos). Geralmente o lote médio nessas regiões, mesmo em Z-3 tem área de 400 a $500 \mathrm{~m}^{2}$.

Segundo Silva (2008), tanto a região do Gramado como a de Barão Geraldo, começam a ser ocupados por loteamentos rurais fechados já a partir dos anos 70 e 
por condomínios urbanos a partir dos anos 80. A área do Taquaral apesar de ter sido pioneira na implantação de condomínios fechados, somente vai ter sua ocupação intensificada a partir dos anos 2000, com a implantação do Shopping D. Pedro.

A região do Alphaville consolida-se em 1997, com a implantação do primeiro empreendimento com esta marca fora da Grande São Paulo, mas em Sousas há empreendimentos aprovados como loteamentos abertos, como Caminhos de San Conrado e Jd. Botânico, e que, mesmo assim, controlam seus acessos já a partir da década de 1980. A partir de meados de 1990, com as facilidades presentes na legislação de uso e ocupação do solo, Sousas passa a concentrar também diversos condomínios fechados.

O grande boom de condomínios fechados a partir de 1990 também pode ser explicado pela facilidade de aprovação vis a vis a produção de loteamentos convencionais dado que a LUOS permite a implantação de Condomínios em glebas, sem a necessidade de doação de áreas públicas (obrigatória em um processo de loteamento pela Lei 6.766/79) e etapas demoradas com a obtenção de licenças de outros órgãos além da PMC, como a do GRAPOHAB, também obrigatória na aprovação de loteamentos ${ }^{70}$.

O tempo de aprovação menor permite uma melhor taxa interna de retorno frente ao capital investido. Além disto, apesar de a LUOS estipular um limite máximo de $28.500 \mathrm{~m}^{2}$ (para Zona-3) ou $40.000 \mathrm{~m}^{2}$ (para Zona-4), não são raros os casos em glebas maiores foram parceladas em glebas menores ${ }^{71}$.

Em relação às áreas estudadas por Silva (2008), entendemos que duas delas exercem uma atratividade mais intensa sobre moradores da Nova Campinas, já a partir da década de 1980, até mesmo por estarem conectadas pelo eixo da Av. Dr. Moraes Salles/ Rod. Heitor Penteado: Gramado e Sousas.

\footnotetext{
${ }^{70}$ Segundo informações dos próprios técnicos da SEMURB, a aprovação de um Condomínio em uma gleba com cadastro atualizado pode ser finalizada em um prazo que pode ser inferior a 90 dias, enquanto que um processo de loteamento, com todas as etapas envolvidas, raramente dura menos de 18 meses.

${ }^{71}$ Este tipo de desmembramento de grandes glebas em glebas menores segue geralmente o seguinte padrão: utilizando-se da possibilidade de um imóvel com uso dito "rural" (ainda que dentro do perímetro urbano) ser parcelado via INCRA, até o limite do módulo rural de cada estado (em São Paulo este limite é de 2 hectares, ou seja $20.000 \mathrm{~m}^{2}$ ), o proprietário divide a gleba original em módulos que atendam o limite imposto pela LUOS e depois aprova separadamente cada empreendimento tipo HMH. Este padrão de "burla" da Lei Federal de Loteamentos (6.766/79) que foi muito comum em Campinas, hoje tem diminuído muito graças à vigilância do Ministério Público.
} 


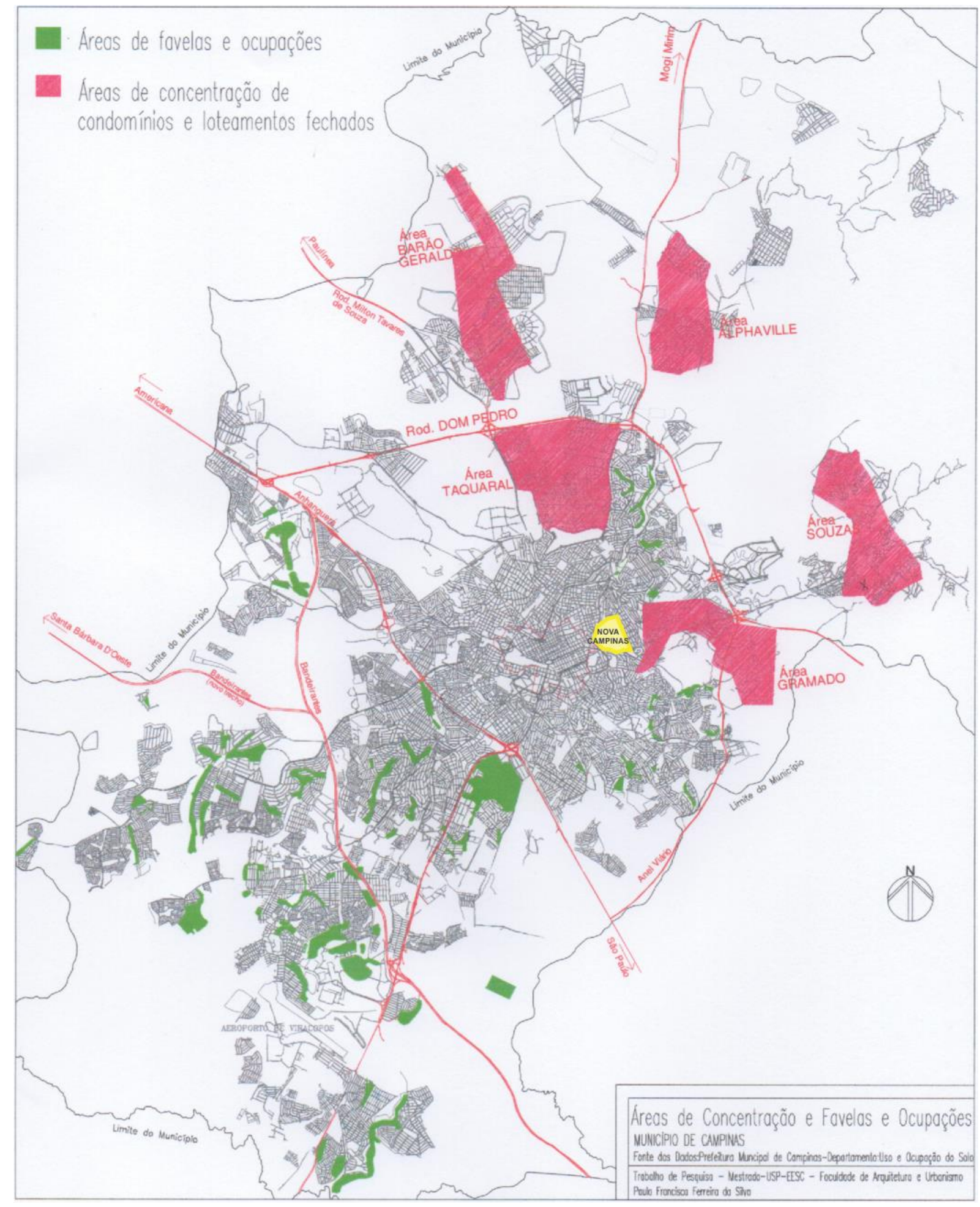

Figura 44: Mapa mostrando as cinco grandes áreas identificadas de condomínios e loteamentos fechados, todas na região do eixo da Rod. D. Pedro I. Podemos observar que as maiores concentrações de favelas e assentamentos precários se concentram no quadrante oposto. Fonte: a partir de Silva (2008). 
A região do Gramado, especialmente, passa a partir da segunda metade dos anos 1980 a consolidar-se no papel de principal região de moradia das elites campineiras, substituindo no imaginário coletivo, a posição que era até então da Nova Campinas ${ }^{72}$.

A região de Sousas, que exercia até então uma atração marginal (pelo menos em relação à moradia de alta renda $)^{73}$, também passa a disputar este papel a partir de meados dos anos 2000, com a implantação de empreendimentos de um novo padrão, (superior ao do San Conrado, Jardim Botânico e Colinas do Ermitage), que são os loteamentos fechados Parque das Araucárias I e II, e Ville Sainte Heléne ${ }^{74}$.

A região do Alphaville também participa deste processo a partir da implantação do empreendimento que the dá o nome (como dissemos, em meados dos anos 90), um loteamento fechado com cerca 1.560 lotes em um perímetro murado de $9 \mathrm{~km}$. A partir dele, vários outros loteamentos e condomínios se instalam em área no seu entorno, como o Parque dos Resedás, o Parque dos Alecrins, e o Residencial Mont Blanc. A própria Alphaville lança em 2004, numa região já mais próxima ao Shopping Galleria, seguindo o eixo da Rod. D. Pedro I em direção à região do Gramado, um segundo empreendimento, o Alphaville D. Pedro. Mais recentemente, em 2013, esta empresa lançou outros dois empreendimentos em áreas próximas (Alphavilles D. Pedro II e III).

A concentração destas áreas no chamado corredor D. Pedro (figura 46), reflete também um movimento de deslocamento do eixo econômico das áreas centrais para este eixo, que tem um caráter metropolitano e regional, com a instalação de grandes estabelecimentos educacionais e de pesquisa (UNICAMP, PUCC, CPQD, LNLS, CENPRA), comerciais e de distribuição (CEASA, Tenda, Makro, Atacadão, Technopark, Praça Capital, Carrefour, Extra, Leroy-Merlin,

\footnotetext{
${ }^{72}$ Conforme afirma Silva (2008,p.107): “[...] A área Gramado caracteriza-se por ser a maior concentração de condomínios e loteamentos fechados no município de Campinas. Gramado era inicialmente ocupada por chácaras de recreio; depois dos anos 1970, passa a ser ocupada por condomínios e loteamentos fechados, processo que já se torna bastante intenso nos anos 1980. A área se destaca em 2000, com mais de 70\% dos responsáveis pelo domicílio com salário superior a $20 \mathrm{~S}$. M. O alto padrão de Gramado é confirmado pela baixa densidade populacional e pelo alto percentual de habitações próprias."

Segundo dados do Censo do IBGE de 1991, compilados por esta autora, a renda média dos chefes de domicílio da região do Gramado é de 33 Salários mínimos.

${ }^{73}$ Sobre a região de Sousas, Silva (2008. p.112) coloca que: “[...]A área Sousas pode ser considerada uma extensão do processo que se inicia em Gramado, pois a ocupação por condomínios inicia-se nos anos 1990 e intensifica-se nos anos 2000. No entanto, há um padrão diferenciado: em 1991, Sousas apresenta média salarial do responsável pelo domicílio superior à média municipal, mas correspondendo a 1/3 da média de Gramado; em 2000, quanto ao percentual de responsáveis pelo domicílio que recebem mais que $20 \mathrm{~S}$. M., Sousas apresenta menos da metade do índice apresentado por Gramado."

${ }^{74}$ Os loteamentos Parque das Araucárias e Ville Sainte Heléne foram aprovados respectivamente em 2005 e 2007.
} 
Decathlon), Shopping Centers (Iguatemi, Galleria e D. Pedro), além de indústrias de tecnologia nas áreas do Polo II da CIATEC e nas rodovias D. Pedro e Ademar de Barros (HP, Motorola, Sansung, etc.), em um processo que ainda está se desenrolando. Mais recentemente, por exemplo, o Banco Santander instalou em uma área do CIATEC, seu centro de processamento de Dados para toda a América Latina (2011) e o LNLS (Laboratório Nacional de Luz Síncotron) está construindo seu segundo acelerador de partículas, que será o maior do hemisfério sul.

No trecho que vai do trevo do distrito de Sousas, à sua conexão com o sistema Anhanguera/Bandeirantes, a Rod. D. Pedro I o caráter de "avenida metropolitana" de que fala Queiroga (2008), assume sua mais aparente feição.

Além dos empreendimentos comerciais de alcance regional, morar próximo aos Shopping Centers, parece exercer uma forte atratividade (figura 45). Em torno do Shopping Galleria, por exemplo, surgiu uma grande concentração de condomínios de escritório de alto padrão que posteriormente resultou também em novos condomínios horizontais e verticais residenciais como Galleria Boulevard, o Acqua Galleria e o The Wonders. Isto se repete no Shopping Iguatemi com vários edifícios de alto padrão se instalando em áreas remanescente da fazenda da FEAC $^{75}$ e no D. Pedro (Região da Villa Bela e empreendimento Le Monde da Rossi).

Fica claro que a mudança no eixo econômico da cidade para uma escala metropolitana e regional, da área central para a região da Rod. D. Pedro I (com a oferta de serviços como escolas e universidades, e comércio em ambientes controlados e supostamente mais seguros dos hipermercados e shopping centers) gera uma enorme atração sobre a moradia para as camadas de mais alta renda.

Além das questões fundiárias, como disponibilidade de áreas para grandes empreendimentos (muitas áreas no entorno da região possuem um zoneamento que só permite a ocupação residencial com grandes lotes e frações ideais), a rodovia acaba num primeiro momento, facilitando o deslocamento de moradores das classes abastadas que muitas vezes possuem vários veículos por família.

\footnotetext{
${ }^{75}$ A FEAC - Federação das Entidades Assistenciais de Campinas é a proprietária da gleba onde em 1980 se instalou o Shopping Iguatemi, sendo sócia no empreendimento e possui ainda um enorme estoque de terras que vão do Shopping até bem depois da Rod. Dom Pedro I. Estas terras são originárias da Fazenda Brandina, doada à entidade pelo casal Odila Egídio de Souza Santos Camargo e Lafayette Álvaro de Souza Camargo, ele ex-Prefeito de Campinas. Além do Shopping Iguatemi, existe um hipermercado Carrefour, megaloja Tok\&Stok, concessionárias de veículos, torres residenciais e comerciais, mas a maior parte da gleba (cerca de 80\%) ainda está por ser desenvolvida.
} 
Posteriormente, a partir do fim dos anos 90, esta facilidade de circulação passa a ser prejudicada pelo enorme aumento de tráfego neste corredor da Rodovia D. Pedro I (e também nas rodovias Ademar de Barros e Prof. Zeferino Vaz) ${ }^{76}$.

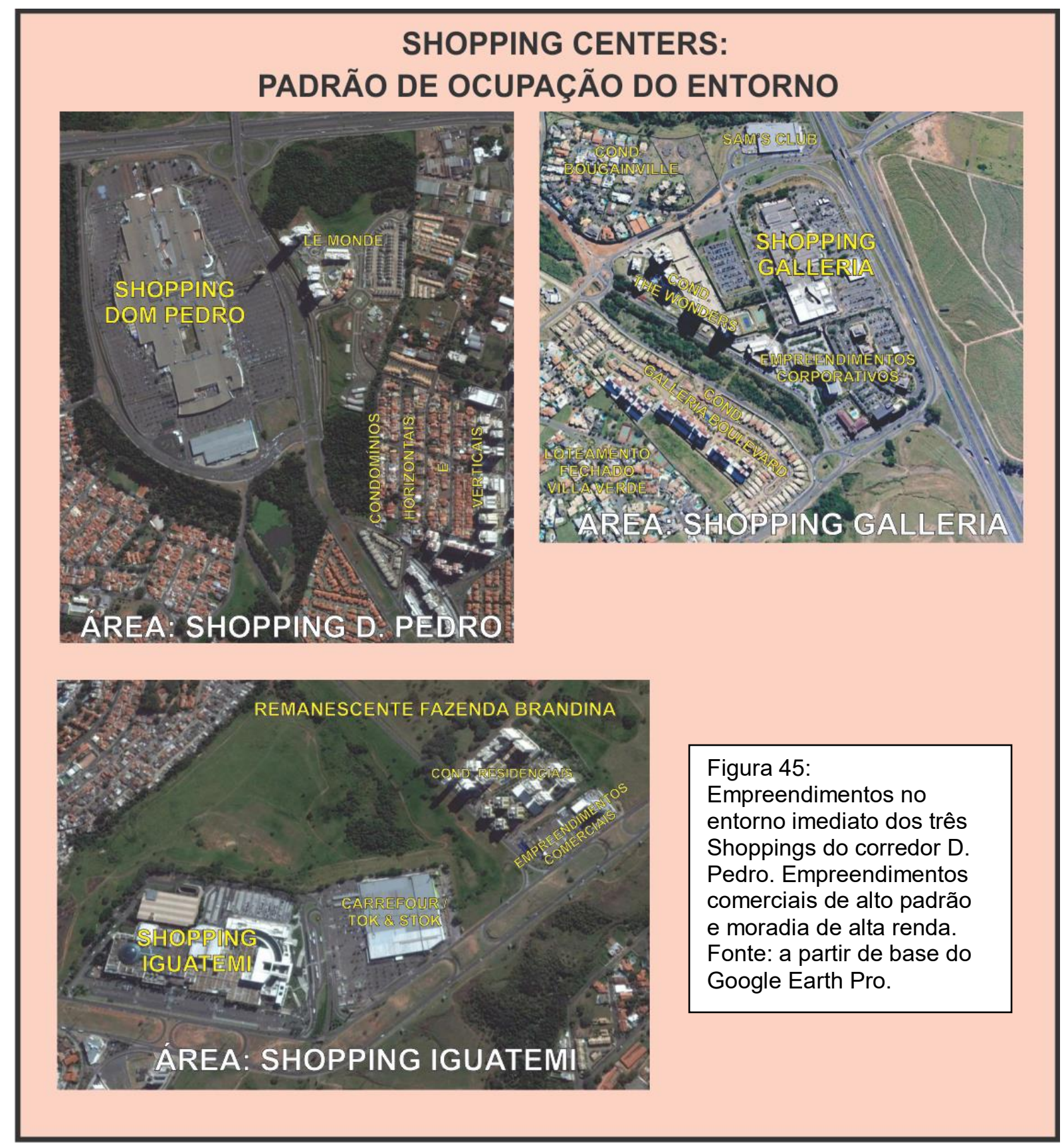

\footnotetext{
${ }^{76}$ Esta situação se modifica devido ao aumento de fluxo na Rodovia D. Pedro I a partir de fins dos anos 1990, com constantes congestionamentos que motivaram a execução de uma $3^{\text {a }}$ faixa de rolamento (2002) e de marginais, estas após intensa pressão do Ministério Publico, estão atualmente em execução.
} 


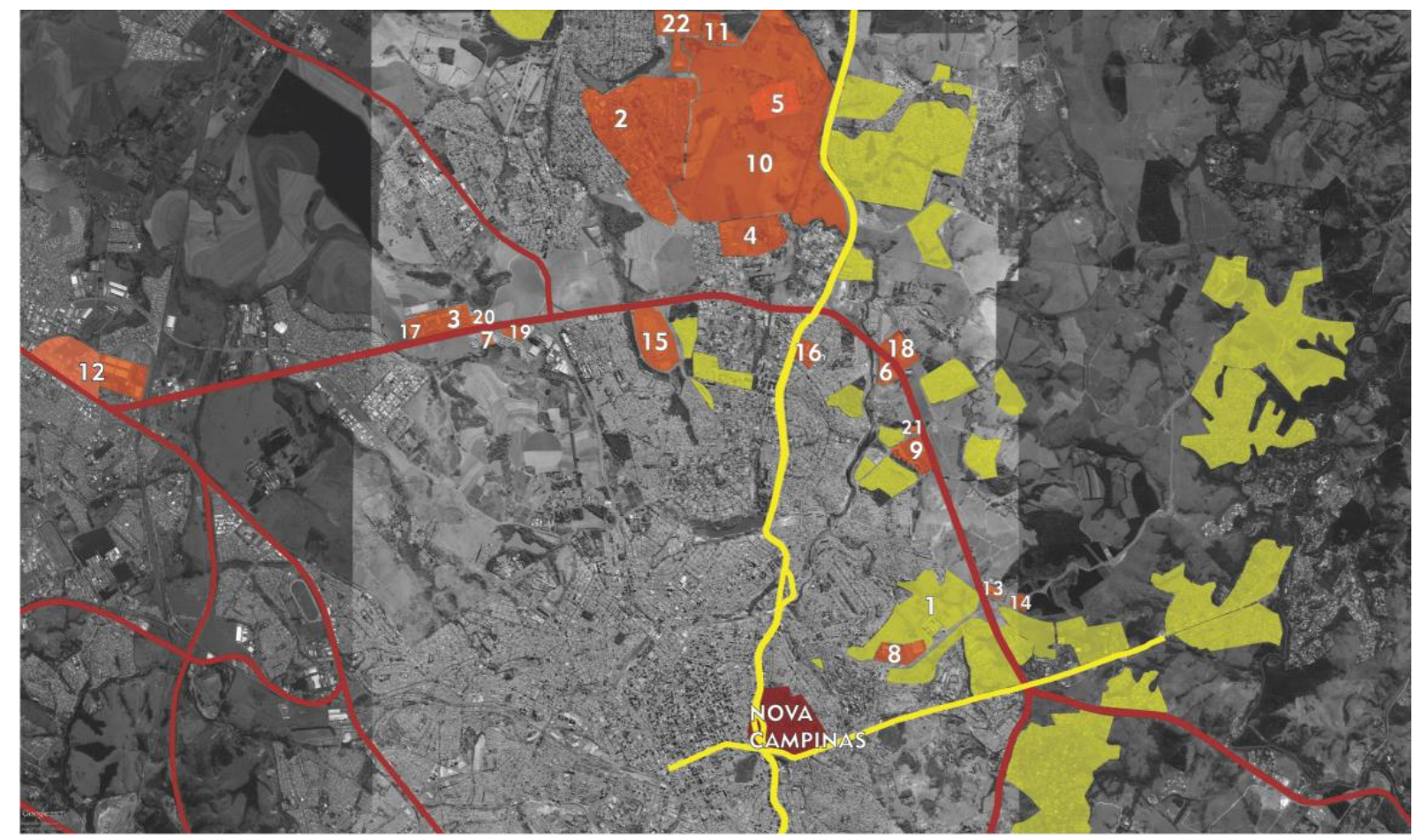

MAPA: EIXO ECONÔMICO METROPOLITANO - CORREDOR D. PEDRO I

\section{LEGENDA:}

1 - Fazenda Brandina (Doada em 1964)

2 - UNICAMP (1966-1970)

3 - CEASA (1975)

4 - CAMPUS I PUCCAMP (1976)

5 - CPqD TELEBRÁS (1976)

6 - CARREFOUR D. PEDRO (1979)

7 - MAKRO ATACADISTA (1980)

8 - SHOPPING IGUATEMI (1980)

9 - SHOPPING GALLERIA (1992)

10 - POLO II CIATEC (1994)

11 - LNLS - Lab. Nac. Luz Síncroton (1997)

\author{
12 - TECHNOPARK (1998) \\ 13 - LEROY-MERLIN (1999) \\ 14 - DECATHLON (2001) \\ 15 - SHOPPING D. PEDRO (2002) \\ 16 - CIDADE JUDICIÁRIA (2003) \\ 17 - TENDA ATACADO (2003) \\ 18 - SANSUNG (2004) \\ 19 - PRAÇA CAPITAL (2005) \\ 20 - ATACADÃO (2007) \\ 21 - SAM'S CLUB (2007) \\ 22 - CPD BANCO SANTANDER (2011)
}

Condomínios e loteamentos fechados de alta renda

Figura 46: O eixo D. Pedro: Empreendimentos e moradia de alta renda. Observa-se que a partir dos anos 70, o eixo econômico de Campinas começa a se deslocar do centro para a Rod. D. Pedro I, adquirindo uma nova configuração metropolitana. A moradia da alta renda se reconfigura, seguindo este deslocamento, com uma clara tendência à concentração de semelhantes. $O$ Zoneamento também joga um papel importante neste cenário, ao impor parcelamentos de baixíssimo adensamento e grandes unidades mínimas (lotes e frações ideais), em zonas monofuncionais, exclusivamente residenciais. Fonte: a partir de base do Google Earth Pro e levantamento do autor. 
O envelhecimento das famílias que ocuparam a Nova Campinas no seu auge, também é um fator a ser considerado. Se os filhos das primeiras famílias que se mudaram para o bairro nas décadas de 1950 e 1960, ao constituírem suas próprias famílias tinham a opção de também se mudarem para um bairro ainda com alto estoque de lotes nas décadas de 70 e 80 , as gerações subsequentes acabam, pelos vários fatores anteriormente mencionados, optando por outros locais de moradia.

As casas de alto padrão (os lotes possuem em média $500 \mathrm{~m}^{2}$ e não raro, as edificações ocupam mais de um lote) que abrigavam as famílias acabam por serem ocupados apenas por casais em idade avançada, ou viúvos. Os herdeiros passam então, como veremos mais tarde, a considerar a venda ou o aluguel dos imóveis que, pelo seu porte, apresentam altos custos de manutenção ${ }^{77}$.

Neste momento, no início dos anos 90 começa a se observar o embate entre o valor de uso e o valor de troca dos imóveis, com parte dos moradores querendo garantir o status quo, através da rigidez na legislação que define o uso como exclusivamente residencial e outros priorizando o rendimento de suas propriedades, vislumbrando uma mudança de uso.

Na discussão que se dará a partir de meados dos anos 90 , em relação à proibição versus liberação de usos comerciais fica patente, inclusive em abaixoassinados endereçados ao poder público, a divisão entre estes dois grupos.

No mapa da Fig. 38 que mostra o Zoneamento estabelecido pela LUOS em 1988, podemos verificar como o loteamento original está seccionado em duas partes desiguais. A menor, junto à Vila Nova Campinas como vimos na ficha de habite-se reproduzida na Fig.29, desenvolveu um padrão de ocupação similar ao do Bairro Cambuí: casas com recuos e afastamentos menores e posteriormente, a partir do zoneamento estabelecido pela Lei 6.031/88, uma verticalização acentuada residencial na Z-6 e mista (residencial, escritórios e hotelaria) na Z-13. O próprio zoneamento atribuído a esta parcela em 1988 segue o padrão do Cambuí - Zona 13 nos 4 quarteirões lindeiros à Av. José de Sousa Campos, e Z-06 no único quarteirão sem frente para esta via (figura 38).

\footnotetext{
${ }^{77}$ Esta situação foi citada como motivo para a desocupação e posterior locação ou venda dos imóveis em várias entrevistas com ex-moradores.
} 


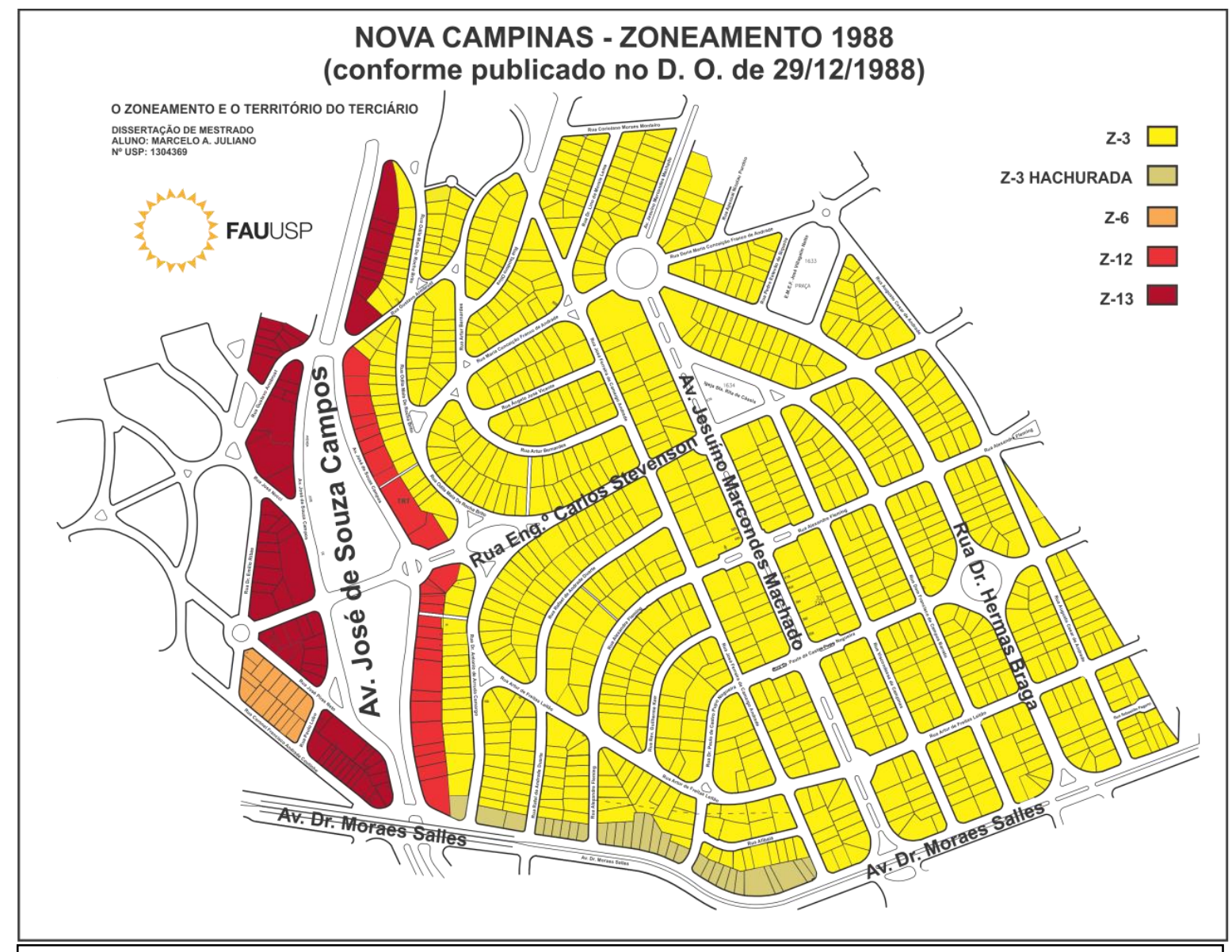

Figura 47: Zoneamento da Nova Campinas, conforme definido pela Lei 6.031/88. Fonte: a partir do Diário Oficial do Município, publicado em 29/12/1988 - Biblioteca Jurídica da SMAJ / PMC. Arte do autor.

Aqui, até mesmo a Padaria existente na confluência das Ruas Emílio Ribas e Eng. ${ }^{\circ}$ Carlos Stevenson, aberta em 1989, recebe o nome de "Pão do Cambuí"

É na parcela situada na margem direita do córrego Proença que se dará o embate entre um padrão de ocupação residencial definido na legislação e uma realidade oposta de um bairro em transformação.

No momento da promulgação da LUOS, em 1988, o Zoneamento atribuído à parcela da Nova Campinas situada na margem direita do córrego Proença foi majoritariamente Z-3 (residencial unifamiliar). Somente os lotes lindeiros à Av. José de Sousa Campos, receberam Zoneamento Z-12 (Comercial e Residencial multifamiliar), e na Av. Dr. Moraes Salles os lotes lindeiros receberam hachuras que permitiam comércio local básico de pequeno porte (Z-3 Hach), no trecho que vai da

\footnotetext{
${ }^{78}$ Em entrevista, o proprietário afirma que estranhava o fato de nos carnês de IPTU do imóvel o endereço indicar Nova Campinas e que só ficou sabendo que a área não pertencia realmente ao Cambuí, quando do debate sobre o tombamento da Nova Campinas em 2004.
} 
Av. José de Sousa Campos até a altura da Rua José Ferreira de Camargo Andrade. Após esta via os lotes com frente para a Dr. Moraes Salles ficaram como Z-3 comum, sem permissão de quaisquer usos comerciais ou de serviços, assim como todo o restante do bairro.

Este zoneamento foi consignado reconhecendo que já neste momento estas duas vias principais possuíam um fluxo bastante elevado ${ }^{79}$, com clara vocação comercial (ainda que na Moraes Salles a liberação tenha sido somente parcial, para comércio e serviços locais e de pequeno porte).

O cruzamento de ambas (figs. 48, 49 e 50) havia sido remodelado em 1977 com o viaduto São Paulo ${ }^{80}$ fazendo a Av. Moraes Salles que conecta a área central aos Distritos de Sousas e Joaquim Egídio, passar por cima da Av. José de Sousa Campos. Juntamente com o viaduto a Av. Moraes Salles foi duplicada até a altura da Av. José Bonifácio, acesso ao Jardim das Paineiras e ao Shopping Iguatemi (que seria inaugurado em 1980).
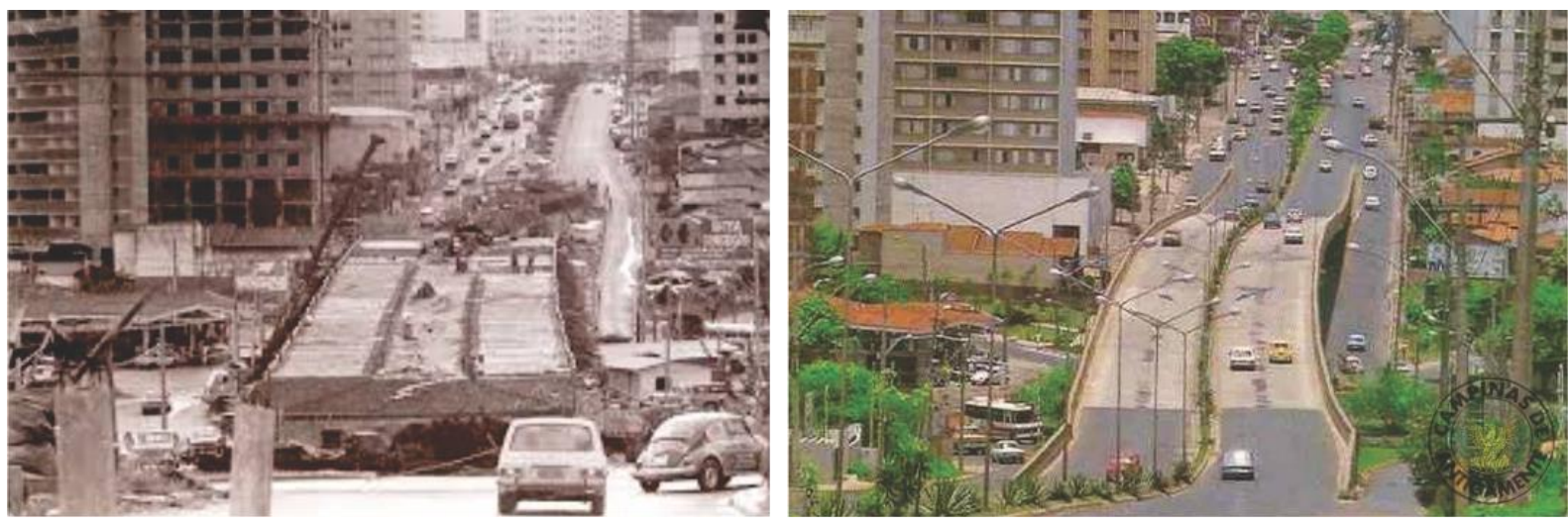

Figuras 48 e 49: Viaduto São Paulo na Av. Dr. Moraes Salles, por sobre a Av. José de Sousa Campos (Norte-sul) em dois momentos: à esquerda, imagem por volta de 1976, durante a fase final de obras e à direita, imagem de 1984. Fonte: CEDOC / RAC através do site www.campinasdeantigamente.com.br

Em 1986, em um terreno pertencente à Nova Campinas, situado na confluência destas duas grandes avenidas foi instalada a primeira loja do McDonald's em Campinas (fig. 31). Em 1988, foi instalada em um imóvel na esquina da Av. José de Sousa Campos com a Rua Dr. Carlos Stevenson, ao lado da Padaria

\footnotetext{
${ }^{79}$ Segundo dados de 2011 da EMDEC, o fluxo nestas duas vias atinge cerca de 47.000 veículos/dia na Dr. Moraes Salles e 56.000 veículos/dia na José de Sousa Campos.

${ }^{80} \mathrm{O}$ viaduto, com cerca de $400 \mathrm{~m}$ de extensão, foi inaugurado em $25 / 01 / 1977$ recebeu a alcunha de "Laurão" por ter sido construído na administração do Prefeito Lauro Péricles Gonçalves (1973-1976).
} 
Inca ${ }^{81}$ na Quadra 02, uma loja de conveniência aberta 24hs, da rede Express (marca comercial de uma rede de lojas de conveniência oriunda de sociedade entre a Shell S/A e o Grupo Pão de Açúcar).

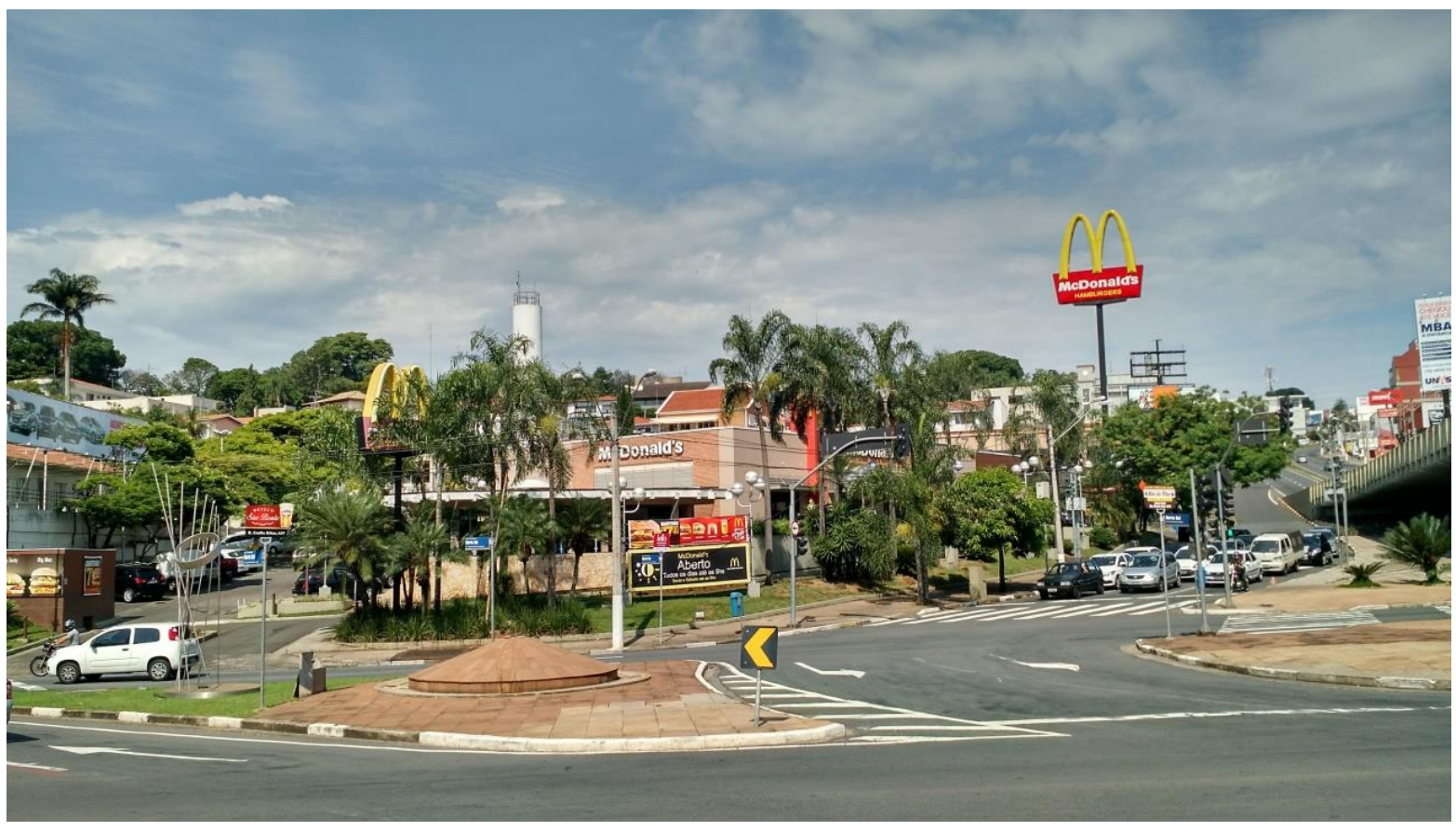

Figura 50: Loja McDonald's na confluência das Avenidas José de Sousa Campos (Via Norte-Sul) e Dr. Moraes Salles. Ocupa um terreno de cerca de $4.200, \mathrm{~m}^{2}$ e tem $1.000 \mathrm{~m}^{2}$ de área construída. Imaqem de 2015. Acervo do Autor.

A chegada de empreendimentos comerciais que atraíam gente de outras regiões da cidade foi recebida com grande preocupação por moradores da Nova Campinas e foi um dos motivos que levou, à constituição da S. B. N. C., Sociedade do Bairro Nova Campinas ${ }^{82}$.

A ata que institui a S.B.N.C. deixa claro que sua principal finalidade seria combater o que via como uma "invasão" indevida do setor terciário em um bairro residencial de elite:

\section{“[...] a) Zelar pelo cumprimento da legislação que instituiu o}

loteamento do Bairro da Nova Campinas , especificamente no que diz

\footnotetext{
${ }^{81}$ Sinal inequívoco do esvaziamento populacional que o bairro enfrenta após 1988, foi o fechamento (em maio de 1994) da única padaria da Nova Campinas, a tradicional padaria Inca que lá funcionou por quase três décadas. Para os Campineiros com mais de 40 anos até hoje a praça circular existente na Rua Carlos Stevenson, denominada Praça Franklin D. Roosevelt, é conhecida como "Balão da Inca".

${ }^{82}$ De acordo com entrevistas com moradores, a Loja Express causava muita perturbação (pela sua localização no chamado Balão da Inca), principalmente por funcionar $24 \mathrm{hs}$, inclusive vendendo bebidas alcoólicas. A aglomeração de jovens e veículos no local varava as madrugadas. Se tornou constante a disputa de "rachas" entre veículos na subida da Rua Carlos Stevenson com vários acidentes relatados. O local passou a ser ocupado por gente oriunda de todos os cantos da cidade, inclusive em comemorações nos jogos da seleção brasileira durante a Copa do Mundo de Futebol de 1990.
} 
respeito aos locais destinados aos estabelecimentos comerciais.

“b) Cancelar os Alvarás porventura concedidos à estabelecimentos comerciais de qualquer tipo, localizados no perimetro estritamente residencial ${ }^{1,83}[$ [...].

A instalação do McDonald's neste local não se deu por acaso. A Av. Dr. Moraes Salles é o único acesso para os distritos de Sousas e Joaquim Egídio e principal caminho para acesso ao Shopping Center Iguatemi, que inaugurado em 1980, em meados da década se consolidava como alternativa para compras e lazer em detrimento da área central que se esvaziava e deteriorava. Além disto, permite a acessar a Rod. D. Pedro I e os condomínios e loteamentos fechados da região do Gramado (Ver Figura 37).

A Av. José de Sousa Campos, conhecida como Via Norte-Sul é a principal conexão da área central com os bairros da região do Taquaral (nordeste) e acesso para as rodovias Ademar de Barros e D. Pedro I, para o Campus I da PUCCAMP e para a UNICAMP.

No início da década de 1990, a Moraes Salles teve sua duplicação estendida do acesso ao pontilhão da Av. José Bonifácio (acesso ao Shopping Iguatemi) até o trevo da Rod. D. Pedro I, conhecido como "Trevo de Sousas" e posteriormente até a entrada daquele Distrito (2000). O trecho lindeiro à Nova Campinas foi sendo ocupado num primeiro momento por escritórios, clínicas e lojas de decoração. Posteriormente se instalaram revendas de automóveis e agências bancárias.

Em 1993 se instala em uma praça na altura da Rua Dr. Hermas Braga (porém do lado do Jardim Paraíso) um pequeno Shopping de Conveniência, denominado "Ventura Mall", com padaria, drogaria, lavanderia, lotérica e outros serviços. O empreendimento é voltado para alta renda, mas pela sua posição na Av. Dr. Moraes Salles, na pista sentido Sousas, foca muito mais em atender aos fluxos de passagem de uma população que já estava se instalando nos condomínios da região do Gramado e de Sousas, cujo acesso se dá obrigatoriamente por esta via do que a um bairro que já se encontrava em declínio.

\footnotetext{
${ }^{83}$ Fonte: Ata de Instituição da S.B.N.C. - finalidades da entidade, alíneas a) e b). Ata lavrada em 18/12/1986 e registrada no $1{ }^{\circ}$ Cartório Privativo de Registro das Pessoas Jurídicas de Campinas. O texto integral encontra-se nos anexos.
} 


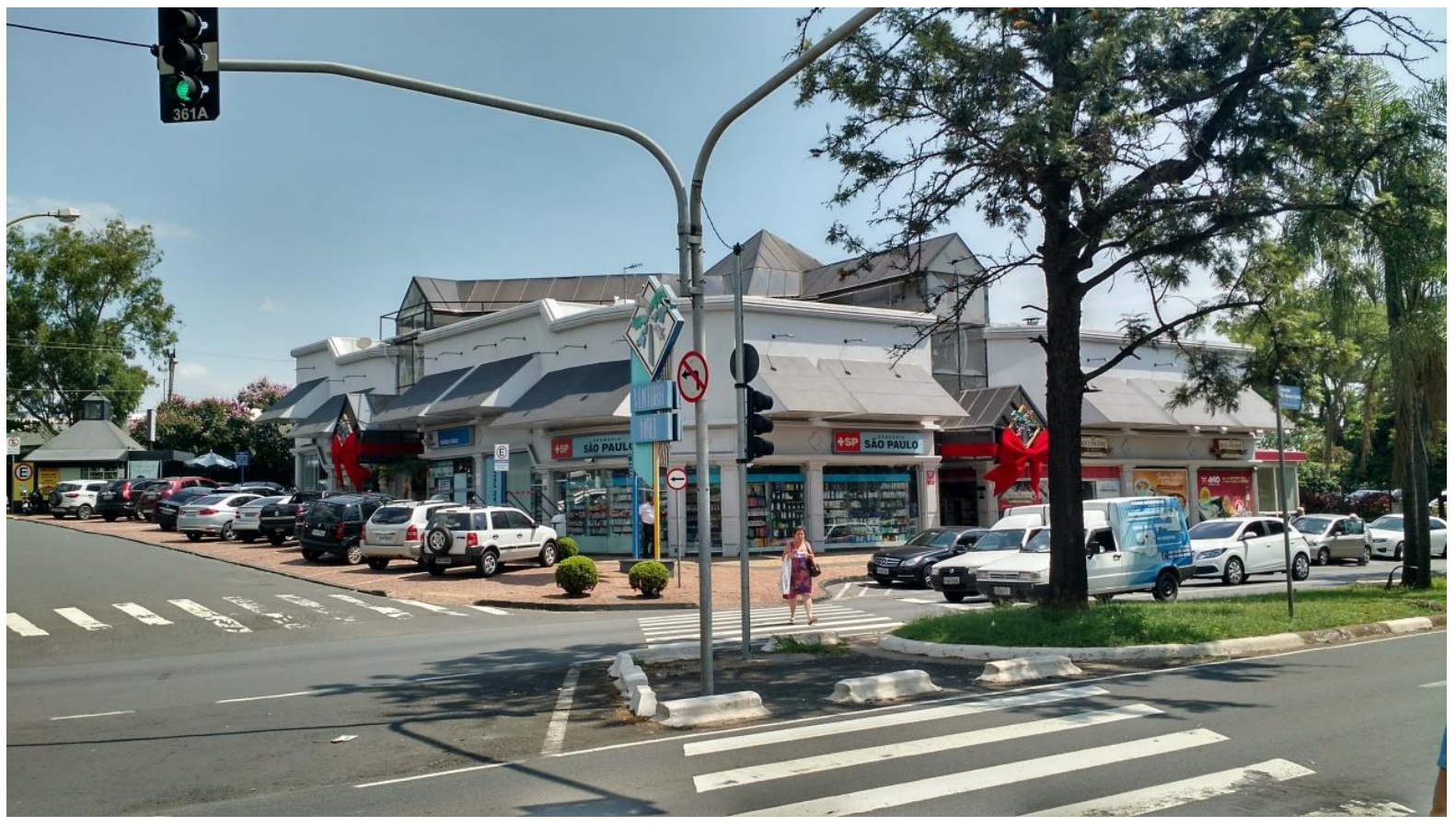

Figura 51: Ventura Mall na Av. Dr. Moraes Salles (foto de 2015), sentido Sousas. Acervo do autor.

A Av. José de Sousa Campos corta a Nova Campinas em seu trecho inicial, a partir da Av. Dr. Moraes Salles e do Viaduto São Paulo, de onde segue como continuação da Av. Princesa D’Oeste, seguindo o trajeto do leito do córrego Proença.

Como já citado a pista da margem esquerda apresenta uma fisionomia assemelhada ao Cambuí. Em 1988 recebeu um padrão de zoneamento análogo ao do Cambuí (Z-13) e conta com edifícios de escritórios, o Hotel Vitória, e nas casas remanescentes com padrão construtivo semelhante ao daquele bairro, clínicas, escritórios e lojas voltadas à alta renda.

Na pista sentido sul da via (margem esquerda do córrego Proença), em um trecho de cerca de $600 \mathrm{~m}$ que corta a Nova Campinas desembocam 7 vias, enquanto que na pista oposta (margem direita), num trecho consideravelmente mais longo (com 930m), apenas 3: a própria Moraes Salles, a Rua Eng. ${ }^{\circ}$ Carlos Stevenson e a Rua Gustavo Armbrust, e que são as únicas ligações entre os dois lados do bairro (fig. 52). 


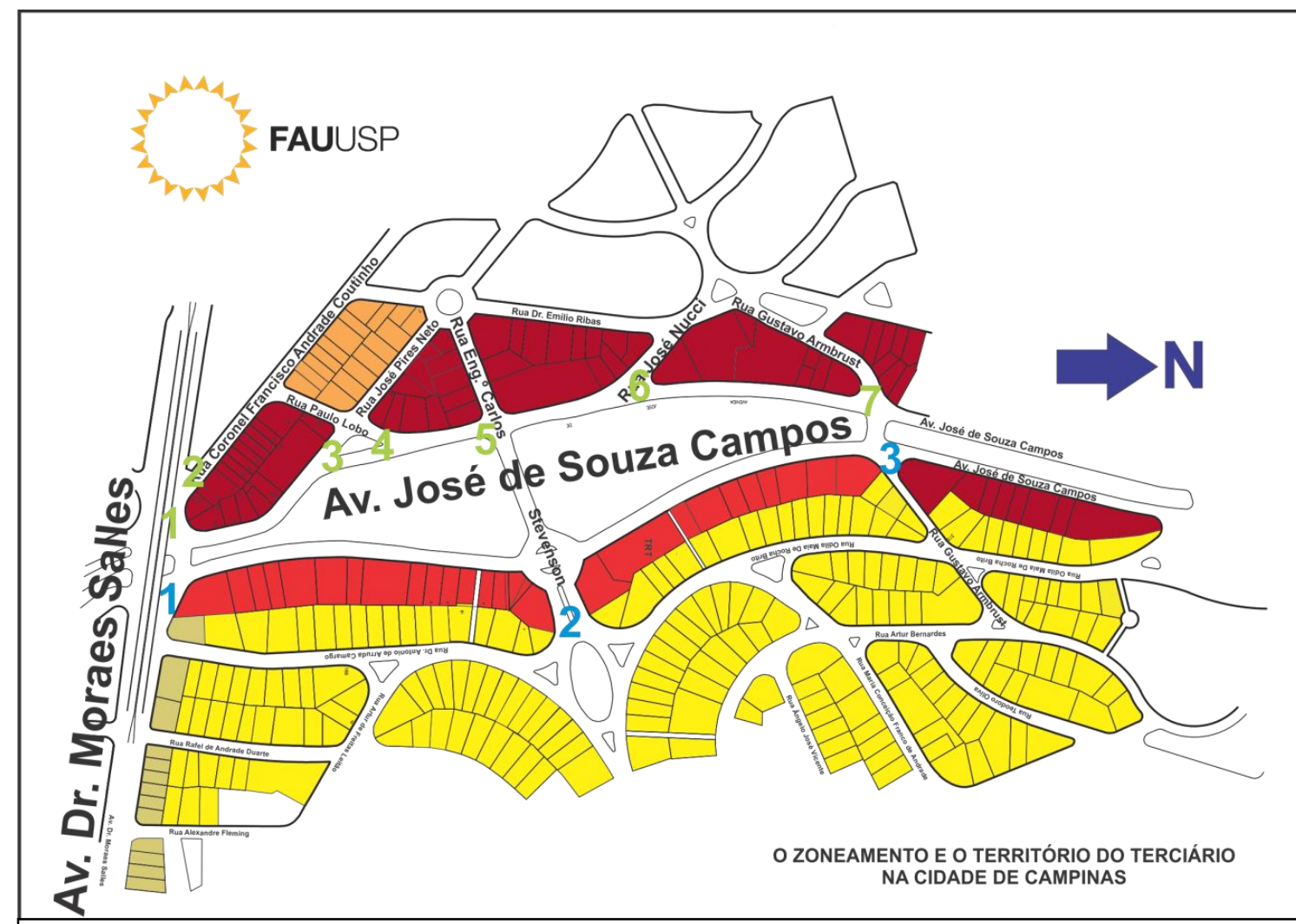

Fig. 52: Mapa com os acessos nos dois lados no Bairro. Fonte: Arte do autor sobre planta do Cadastro Municipal.

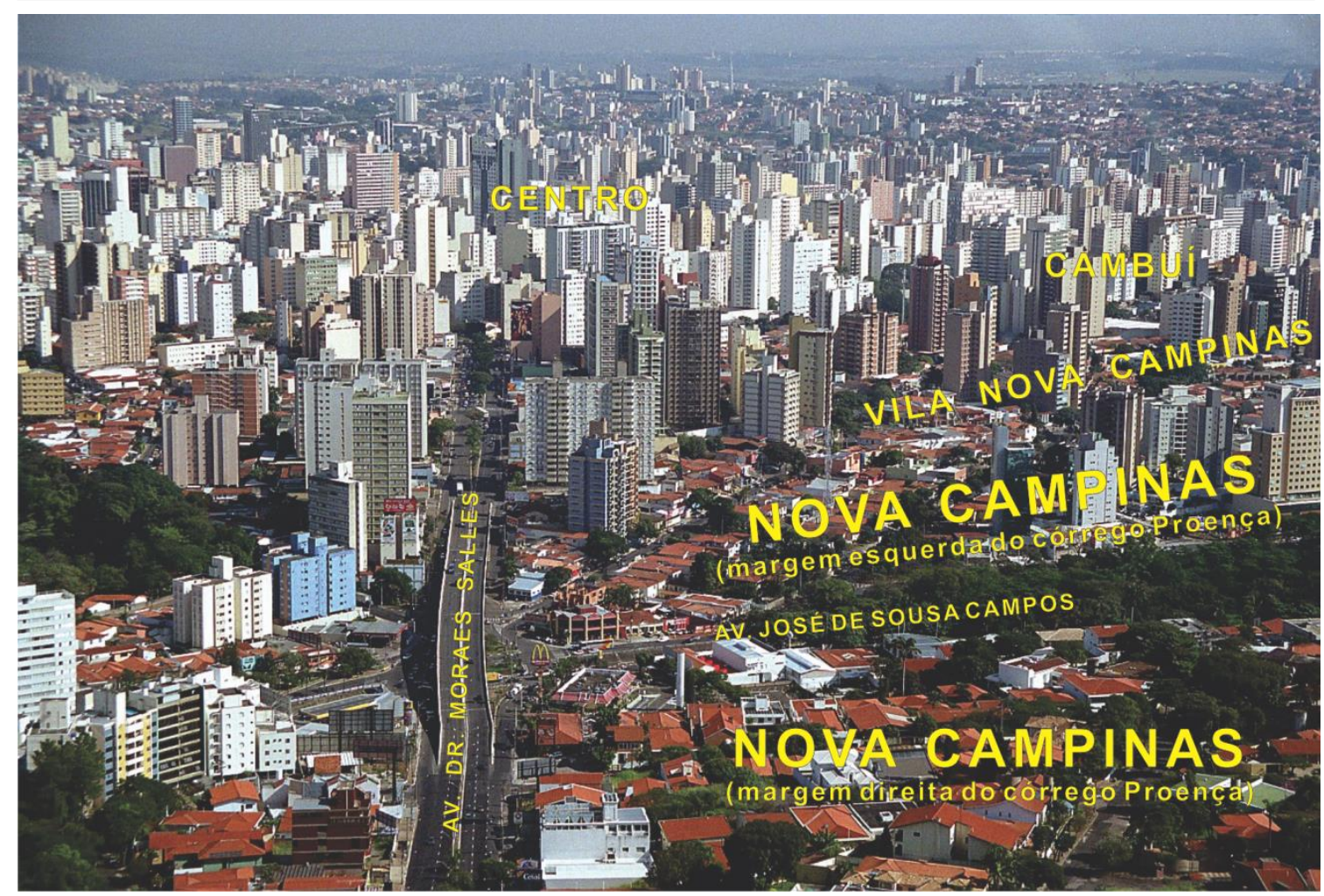

Fig. 53: Imagem aérea mostrando o cruzamento das Avenidas Dr. Moraes Salles e José de Sousa Campos, mirando a área central da cidade. Fonte: a partir de acervo DECOM / PMC, 2007 com anotações do autor. 
$\mathrm{Na}$ margem direita, se observa um padrão de ocupação com recuos e afastamentos de acordo com o padrão estabelecido pelo Decreto que criou a Nova Campinas em 1946. Como citado anteriormente, aqui se instalaram o McDonald's e o Express e, posteriormente, lojas da Pizza Hut (1993) e Burger King (2007). Nos três longos quarteirões que estão neste trecho também existem concessionárias de veículos (Honda, Toyota, multimarcas), drogarias, lojas de decoração, lanchonetes, clínicas, uma torre residencial, duas torres comerciais de escritórios, e um equipamento público de grande porte, do poder judiciário, que é o Fórum Trabalhista da $15^{\mathrm{a}}$ Região, instalado em 2007.

A Av. José de Sousa Campos, apesar de sempre ter sido uma ligação importante sofreu durante muitos anos com inundações do Córrego Proença durante chuvas mais intensas, especialmente no trecho que vai do cruzamento da Rua Gustavo Armbrust até a altura da Av. Orosimbo Maia (onde este se junta ao córrego do Serafim, formando o Ribeirão Anhumas) o que diminuía sua atratividade como ponto comercial. Em 1996, uma grande obra de saneamento foi realizada, com drenagem, reforço das pistas e a canalização do córrego neste trecho ${ }^{84}$.

A partir deste momento a Norte-Sul se consolida como o principal endereço de negócios em Campinas, com seus imóveis atingindo o $\mathrm{m}^{2}$ mais caro da cidade ${ }^{85}$.

Ocupada, até então, por lanchonetes, algumas clínicas e poucas residências, pouco tempo depois desta intervenção passa a receber prédios comerciais de escritórios de alto padrão, concessionárias e prestadoras de serviços para veículos, bancos e outros estabelecimentos que se beneficiam da concentração de renda e pelo enorme fluxo de pessoas.

O trecho que atravessa a Nova Campinas, com as praças projetadas nas margens do córrego Proença apesar do alto tráfego ainda guarda uma qualidade ambiental e paisagística pouco comum em Avenidas com este tipo de fluxo, com excelente arborização e espaços para caminhada (fig. 34). Recentemente, em outubro de 2015, a Avenida José de Sousa Campos ganhou uma ciclovia com

\footnotetext{
${ }^{84}$ Após estas obras foi executado um "piscinão" em 2000, na confluência dos dois córregos, e que passa por manutenção constante. Desde então, somente num episódio totalmente atípico a via ficou completamente intransitável por um período mais longo, de várias horas (em $17 \mathrm{fev}$ de 2003, quando choveu $120 \mathrm{~mm}$, sendo 63 no espaço de $1 / 2 \mathrm{~h}$ ).

Fonte: EMDEC / SETRANSP http://www.emdec.com.br/hotsites/nossa cidade/norte sul.html acesso em 21/set/2015.

${ }^{85}$ Segundo consultas às imobiliárias De Lange, Lopes, De Lucca e Abyara o valor de terrenos nesta via atingiu por volta de 2013 valores na faixa de $\mathrm{R} \$ 10.000$ a $\mathrm{R} \$ 14.000$ por $\mathrm{m}^{2}$, variando de acordo com o tamanho e posição do imóvel.
} 
$1,3 \mathrm{~km}$, no trecho que vai da Rua Gustavo Armbrust até a Av. Orosimbo Maia.

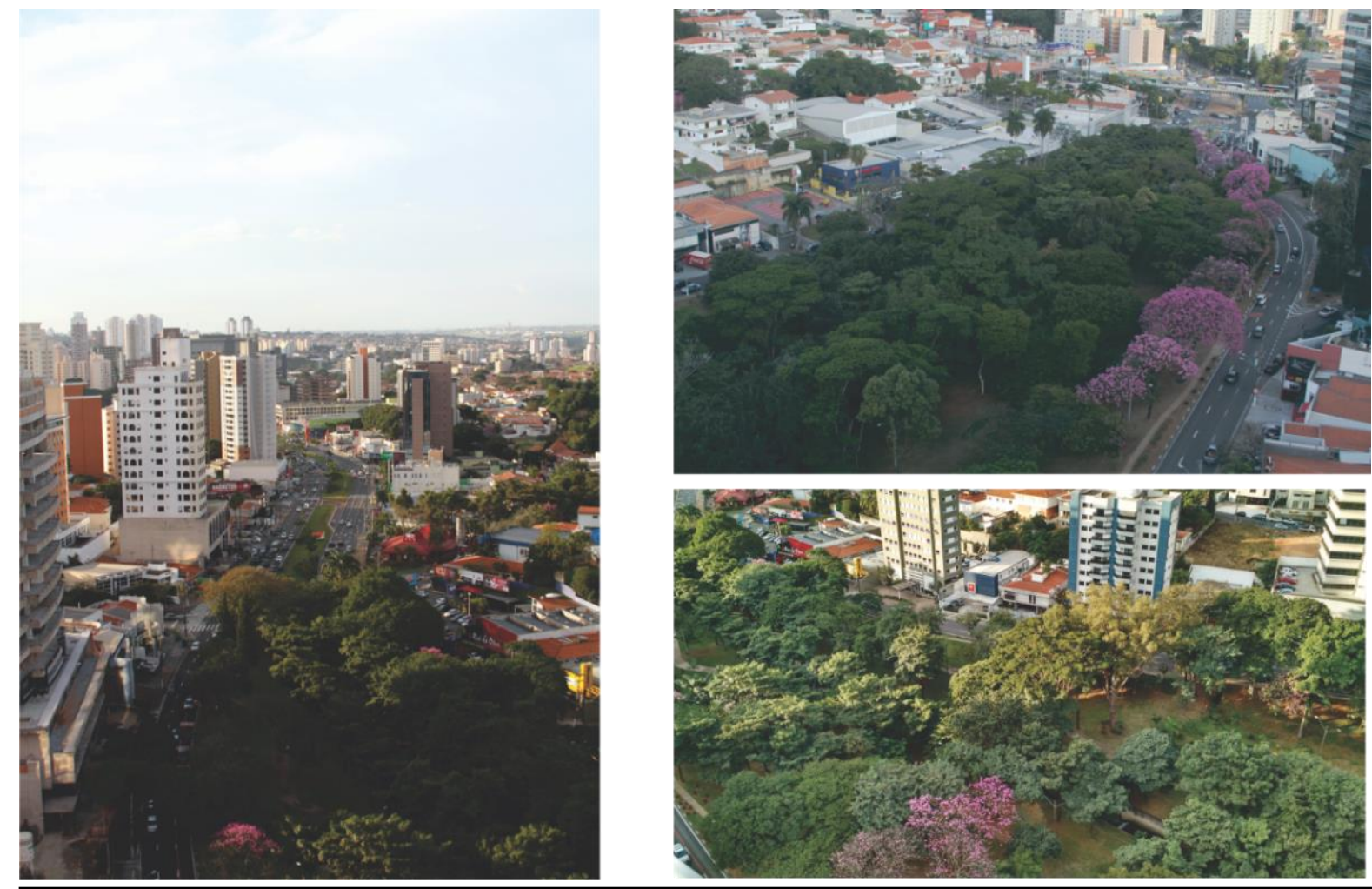

Figura 54: fotos tiradas do alto do heliponto do hotel vitória: apesar dos fluxos intensos da Av. José de Sousa Campos, o miniparque linear projeto por Macedo Vieira às margens do Córrego Proença, no trecho da Nova Campinas, permanece com uma ótima qualidade ambiental, se estendendo desde a altura da Rua Gustavo Armbrust (imagem à esquerda) até quase o Viaduto São Paulo (alto à direita).

\section{3 - Os impasses entre a lei e a dinâmica urbana:}

Com todos estes fatores que descrevemos remodelando as dinâmicas urbanas, o modelo de zoneamento monofuncional consolidado pela promulgação da Lei $N^{\circ} 6.031 / 88$ aumentou a separação entre a cidade legal e a cidade real.

Como já citamos anteriormente, ao contrário do que estabelecia a LUOS, mesmo os bairros tradicionais consolidados de alta renda já apresentavam um padrão de uso muito menos homogêneo, quando da sua promulgação.

No caso da Nova Campinas, como procuramos demonstrar, ocorre a percepção de que há um aumento na oferta de imóveis a partir do início dos anos 90, de excelente padrão construtivo, adequados à instalação de escritórios ou 
clínicas, com localização quase central e facilidade de acesso, na região com maior infraestrutura da cidade.

Em algumas áreas exclusivamente residenciais, Z3, houve a opção por hachurar a Z-3, criando uma subcategoria de zoneamento (geralmente em esquinas de algumas avenidas mais movimentadas), iniciando um processo que culminou nas 59 variantes de zoneamento existentes hoje. Esta alteração visava permitir comércio local básico, mas somente em edificações de pequeno porte, na época inferior a $250,00 \mathrm{~m}^{2}$. Esta, restrição, por sua vez, impedia a legalização de atividades que nestes bairros de maior renda, tendo em vista a área construída acima do limite de enquadramento permitido, das edificações existentes.

Houve, na verdade, um processo de flexibilização das Z3 (Lei n 8.737/96) em bairros protegidos. Porém o discurso da exclusividade permaneceu até bem pouco tempo e, quando aconteceram alterações, estas foram sempre muito tímidas envolvendo apenas trechos de algumas vias. Isto somente viria a se modificar mais radicalmente em 2014, com a edição da Lei Complementar n 62/14. No entanto, ainda aqui as alterações foram no sentido reconhecer que alguns (na verdade, hoje a maioria) dos imóveis residenciais unifamiliares, só adquirem valor de troca quando recuperam o seu valor de uso. Caso contrário, permanecem vazios.

A limitação do porte das atividades terciárias e a impossibilidade de edificar tipos de ocupação diferentes do residencial unifamiliar permanecem até hoje. Em resumo, a lei acabou por reconhecer que as atividades terciárias possam ocupar algumas áreas com imóveis originariamente residenciais, porém não permite que se instalem em imóveis projetados e construídos adequadamente para suas atividades.

De qualquer forma, os imóveis foram sendo paulatinamente ocupados por escritórios e atividades comerciais e de serviços, usos que atualmente significam mais de $50 \%$ dos imóveis do bairro, ainda que a lei o classifique como "protegido" 86 ;

Aqui temos um exemplo de fortes equívocos do modelo de zoneamento restritivo adotado pela Lei de Uso e Ocupação do Solo de Campinas e suas consequências na dinâmica da cidade.

Os padrões de conflitos decorrentes desta incompatibilidade da legislação vis

\footnotetext{
${ }^{86}$ Dados conforme levantamento realizado pelo autor, em fevereiro de 2015.
} 
a vis o uso real do solo, tornam este bairro um estudo de caso interessante, contribuindo para melhor entender as limitações da legislação na definição da localização das atividades de comércio e serviços nas cidades(VARGAS, 2015).

Devido a seu perfil de bairro de elite, as transformações no seu padrão de uso do solo sempre foram polêmicas, e apesar das várias alterações na LUOS que suavizaram as restrições ao terciário na maior parte da cidade, na Nova Campinas estas alterações nunca resolveram a questão dos usos e ocupações clandestinos, de forma minimamente adequada. Mais que isto, a relutância em reconhecer que o modelo de zoneamento restritivo salvaguardado aqui pela já citada listagem de "bairros protegidos", resultou que as alterações quase nunca atingissem seus objetivos, configurando remendos que ao invés de corrigir as distorções, potencializam-nas prejudicando muito as qualidades urbanísticas e ambientais do bairro, o que apenas confirma toda a discussão presente na literatura sobre a produção do espaço urbano, seus principais agentes e seus conflitos de interesse.

É evidente o embate entre interesses conflitantes de grupos definidos de proprietários e que culminaria, numa tentativa de tombar o bairro como patrimônio de Campinas, numa manobra de parte dos proprietários que buscava garantir sua identidade como espaço de habitação privilegiada de parcela significativa da elite campineira.

De um lado, ficavam os proprietários e residentes que se opunham ao que seria uma "invasão comercial" indevida em um bairro que deveria ser estritamente residencial, e por outro, uma parcela significativa também de proprietários e residentes solicitando alterações no zoneamento, de maneira a permitir os usos comerciais e de serviços bem como os usos multifamiliares verticais ${ }^{87}$.

Em 1995, diante das várias demandas resultantes do embate entre a legislação e a cidade real, o Poder Executivo envia à Câmara Municipal projeto de Lei de autoria do Poder Executivo resultando na promulgação da Lei $n^{\circ} 8.737 / 96$ que flexibiliza os usos comerciais nas áreas exclusivamente residenciais, Zoneadas de Z-1 a Z-7 (pela Lei 6.031/88) , $^{88}$ em imóveis residenciais com data de Habite-se anterior à de sua promulgação, com a exceção para os bairros ditos "protegidos",

\footnotetext{
${ }_{88}^{87}$ Os abaixo-assinados podem ser vistos nos anexos.
} 
pela alínea d) do Inciso III do Art. 27 da LUOS, todos bairros de moradia das camadas de renda mais alta da cidade.

No caso da Nova Campinas, que está incluída nesta lista de bairros protegidos, a lei cria uma exceção para os lotes com frente para a Av. Dr. Moraes Salles, permitindo determinados usos comerciais, porém com o porte restrito ao que a LUOS define como "pequeno porte ${ }^{89}$ ", o que à época estava limitado a $250,00 \mathrm{~m}^{2}$. A promulgação deste diploma não causou grandes polêmicas devido ao excesso de tráfego, em volume e velocidade, na Av. Dr. Moraes Salles a tornar pouco atrativa como área residencial.

Após a Lei de 1996, foram promulgadas outras duas que atualizaram e ampliaram a flexibilização do zoneamento para os usos terciários nas áreas zoneadas de Z-3 a Z-7. Em 2000 (Lei n 10.566/00) e em 2014 (Lei Complementar $n^{\circ}$ 62/14), sempre mais permissivas, porém com restrições específicas em relação à Nova Campinas, onde atinge apenas as vias principais ${ }^{90}$.

Corroborando nossa percepção da inviabilidade do modelo de zoneamento adotado pela LUOS em 1988 diante das dinâmicas urbanas relacionadas com o setor terciário, cremos ser importante assinalar o tom da justificativa apresentada pelo texto do PL615/95 de 23 de outubro de 1995 de autoria do Poder Executivo, que era assim endereçado ao poder legislativo:

“[...] A Lei $n^{\circ}$ 6.031/88, Lei de Zoneamento em vigor, ao legislar sobre uso do solo, atribuiu usos comerciais, de serviços, institucionais e industriais a áreas determinadas da cidade, fundamentada no conceito de proteger o uso habitacional, isolandoo dos demais usos urbanos. Assim, os usos comerciais, de serviços, institucionais $e$ industriais, não são permitidos nas zonas residenciais pela citada lei. Em que pese o fato da dinâmica urbana definir um padrão de estrutura em que se verifica a mescla de usos, muito mais que sua segregação, nos espaços previamente definidos

\footnotetext{
${ }^{89}$ Esta definição de pequeno porte com o limite de $250,00 \mathrm{~m}^{2}$ passaria em $1998 \mathrm{com}$ a Lei ${ }^{\circ} 9.785$ para $500,00 \mathrm{~m}^{2}$ o que, dado o tamanho médio das edificações da Nova Campinas, também se mostrou inadequado.

${ }^{90} \mathrm{Na}$ proposta original do Poder Executivo, em relação às vias internas do bairro a LC nº62/2014 libera alguns tipos de comércio na Eng ${ }^{\circ}$ Carlos Stevenson e na Dr. Jesuíno e alguns serviços na Dr. Hermas Braga. Posteriormente, através de emendas de vereadores mais 4 vias tiveram uma liberação muito mais permissiva: Gustavo Armbrust, Artur Bernardes, Rafael Andrade Duarte e Dr. José Ferreira de Camargo. Para a Av. Dr. Moraes Salles a LC também libera atividade de médio porte, isto é, até $1.000,00 \mathrm{~m}^{2}$ de construção. Fonte: PLC 29/13. Arquivo da Câmara Municipal.
} 
pela lei.

Com efeito, desde a promulgação do citado diploma legal, no final dos anos oitenta, vem ocorrendo a intensificação da tendência, que já era incipiente naquela época, de implantação de outros usos urbanos nas zonas residenciais, seja por conta do crescimento da economia informal, ensejada pela crise econômica, seja por conta da terceirização de serviços.

Como bem sabem os nobres vereadores, a terceirização de serviços, uma tendência da economia capitalista, mesmo nos países em desenvolvimento como o nosso, reforçou o aparecimento de pequenos negócios, exercidos na própria moradia. Hoje, também é usual que o profissional autônomo, seja ele técnico, ou não, utilize a moradia para desenvolver atividades econômicas de pequena envergadura, prestando serviços, ou instalando comércios de diversas naturezas.

Também não desconhecem os vereadores, que muitas edificações perderam a finalidade de moradia por se localizarem em ruas com tráfego intenso elou pesado, propiciando novas utilizações para uso residencial. Assim é que edificações residenciais localizadas em corredores urbanos, ou mesmo localizadas no interior de alguns bairros da cidade como Botafogo, Guanabara, Castelo, Jardim Chapadão, Chácara da Barra, Flamboyant, etc., são hoje utilizadas para abrigar pequenas clínicas médicas, boutiques, comércios de pequeno porte, enfim sem que isso signifique prejuizo necessário às moradias do entorno.

Em suma, a dinâmica urbana, o crescimento da cidade e a própria conjuntura econômica, forjaram uma configuração de uso e ocupação do solo em Campinas distinta daquela prevista pela Lei $n^{o}$ 6.031/88, ocasionando o fenômeno da clandestinidade dos usos comerciais, de serviços, institucionais e industriais, que funcionam em edificações residenciais, fenômeno esse que atinge cerca de $70 \%$ do comércio e serviços implantados na cidade, conforme estimativas do Departamento de Urbanismo desta Prefeitura.

$\underline{\text { Boa parte desta clandestinidade é forjada pela rigidez das }}$ regras da lei, que impede, através de normas que não tem aderência 

sempre são incômodos com o uso residencial $[\ldots . .]^{91}$

Podemos ver claramente neste texto que se constatava que o modelo de zoneamento adotado em Campinas era descolado da realidade de uma cidade que encaminhava a passos largos, seu processo de metropolização.

Apesar de o texto do Projeto de Lei não romper explicitamente com o modelo de zoneamento, a exposição de motivos do Projeto de Lei não deixa margens à dúvidas: apenas sete anos após a promulgação da LUOS, o próprio Poder Executivo já tinha a compreensão de que este modelo não se adequava à realidade de uma cidade onde a atividade econômica se voltava cada vez mais ao setor terciário. Ainda que tenha mantido praticamente as mesmas definições e o discurso da separação de usos em sua raiz, a sua flexibilização contribuiu decisivamente para evitar uma paralisia na economia da cidade, mesmo que em muitos bairros as atividades terciárias ainda permaneçam na informalidade, por dificuldades de adequação.

Esta incompatibilidade entre o discurso e a realidade, mediada por leis que a tornam o uso e a ocupação do solo em Campinas matéria de difícil apreensão inclusive por técnicos (o que dizer então, do cidadão comum?) transformaram o Território de Campinas numa colcha de retalhos onde convivem 59 tipos de zoneamento diferentes. ${ }^{92}$

Em relação ao bairro da Nova Campinas, pouca coisa mudou neste primeiro momento, já que a alteração no eixo da Av. Dr. Moraes Salles não trouxe grandes polêmicas e a Av. Jesuíno Marcondes Machado, uma das principais vias do loteamento, somente recebeu alteração no trecho externo ao bairro.

Devido ao grande fluxo de veículos, se instalam nos corredores periféricos, além de clínicas e escritórios de advocacia, muitas atividades ligadas ao setor automotivo, de concessionárias de veículos a lojas de pneus e prestadores de serviços, inclusive seguradoras.

Já nas duas principais vias internas, a Av. Jesuíno Marcondes Machado e a

\footnotetext{
${ }^{91}$ Arquivo da Câmara Municipal - PL 615/95. Protocolo 39.412/95. Trecho do Ofício de encaminhamento do PL pelo Prefeito Municipal José Roberto de Magalhães Teixeira ao Presidente da Câmara Municipal, Romeu Santini. Grifos nossos.

9259 zonas diferentes identificadas, conforme consulta ao site de zoneamento da PMC, considerando-se todos os subtipos, como BG, APA, Hachuras, etc. https://zoneamento.campinas.sp.gov.br/ acesso em 10/mai/2014.
} 
Rua Carlos Stevenson, além dos tradicionais serviços de saúde e jurídicos, consolida-se uma forte presença de lojas de móveis e decorações, inclusive showrooms de móveis planejados ${ }^{93}$.

Parte dos proprietários procurou então a ajuda de vereadores com o objetivo de amenizar as restrições de uso e viabilizar a locação ou mesmo a comercialização de seus imóveis, culminando com a Lei $n^{\circ} 10.566 / 00$ de autoria do Vereador Francisco Sellin que atualiza a Lei $n^{\circ} 8.737 / 96$, e em um de seus artigos possibilita a instalação de algumas categorias de usos de serviços nestas duas vias, alteração que viria a provocar uma reação mais forte de parte dos moradores.

Inicialmente, a lei alterava o Art. $1^{\circ}$ da 8737/96, atualizando a data de referência para o ano 2000:

Art. $1^{\circ}$ - $O$ artigo $1^{\circ}$ da Lei 8.737 , de 10 de janeiro de 1996 que "Dispõe sobre a concessão de Alvará de Uso em edificações existentes em áreas do Municipio de Campinas, zoneadas pela Lei $n^{o}$ $6.031 / 88$ em Z1, Z2, Z3, Z5, Z6 e Z7 (...) passa a vigorar com a seguinte redação.

"Artigo $1^{\circ}$ - As edificações aprovadas e com "habite-se" expedido até o dia $\underline{31 / 12 / 2000}$, situadas em áreas zoneadas com Z1, Z2, Z3, Z5, Z6 e Z7, além do uso habitacional permitido pela Lei $n^{\circ}$ $6.031 / 88$ poderão ser destinadas, parcial ou totalmente, aos usos comercial, institucional, industrial ou de serviço, desde que observadas as condições estabelecidas por esta lei".

Durante sua tramitação, foi apresentada emenda do Vereador Antonio Rafful que propunha, entre outras alterações, incluir o trecho da Av. Jesuíno Marcondes Machado pertencente à Nova Campinas e a Rua Carlos Stevenson nas áreas abrangidas, ainda que com algumas restrições, sendo que apenas determinados tipos de serviços estariam permitidos, mas não usos comerciais.

Esta diferenciação, que a princípio pode-se estranhar, se explica pelo fato de que escritórios de serviços passam uma percepção de ser atividade mais ordeira do que atividades que envolvam trocas de mercadorias físicas, e por isto teriam menor

\footnotetext{
${ }^{93}$ A Av. Jesuíno Marcondes concentra alguns dos maiores terrenos e imóveis (em áreas e testada) do bairro, além de ser praticamente plana no trecho em que corta a Nova Campinas. Possui uma ocupação diversificada, porém em nosso levantamento de usos identificamos uma certa aglutinação nos setores de decoração (móveis e móveis planejados) e imobiliário.
} 
probabilidade de geração de impactos indesejáveis. A ausência de mercadoria física parece tornar mais palatável a uma vizinhança elitista, a presença de serviços (especialmente os ligados a alguma atividade profissional "nobre" como medicina ou direito) ao contrário do comércio.

A realidade, porém, pode se comportar de maneira diversa, como em relação ao volume de trânsito gerado pelo setor de serviços, pois enquanto as trocas comerciais tendem a ocorrer em um prazo mais curto, com maior rotatividade e, dependendo do segmento, concentram-se em horários de pico, escritórios de serviços demandam mais vagas, tanto pelo número e padrão de transporte dos funcionários, como pelo tempo médio gasto por clientes ${ }^{94}$.

Ao propor incluir estas vias no escopo atingido pela flexibilização, o vereador (que não obstante, também era residente na Nova Campinas) alegava que:

“[...] dentro desses bairros estritamente residenciais nós temos alguns imóveis completamente distorcidos. Nós temos comércios, escritórios que não possuem o devido Alvará de Funcionamento. A Secretaria de Obras, pelo seu Departamento de Urbanismo não tem fiscais suficientes para fiscalizar essas irregularidades. Ai o que nós fizemos? Nós permitimos, abrimos, que nas vias arteriais definidas pela Lei de Polos Geradores de Tráfego, se fosse permitido algum tipo de servico para que aqueles imóveis não fiquem parados, por que hoje ninguém aluga uma casa na Jesuíno Marcondes Machado, na José Bonifácio, na Heitor Penteado. Então, principalmente nestas vias, a Carlos Stevenson, que a característica já está toda alterada. Apenas nós não temos a legalidade da situação, para que a Secretaria de Obras, através do seu Departamento competente, forneça os alvarás para essas pessoas. Então, nós temos inúmeras empresas instaladas, eu digo isso em relação à Nova Campinas porque eu moro lá e sei de inúmeros imóveis que trabalham de porta fechada e são escritórios de advogados, de médicos, de empresas de telefonia, de empresas de

\footnotetext{
${ }^{94}$ Reportagem do Jornal Correio Popular de 02/04/2015, ilustra bem o a dificuldade de se conseguir uma vaga em via onde se concentram escritórios de serviços funcionando em edificações adaptadas de residências, no caso a Rua Dr. Hermas Braga. Irritada com os carros que paravam na frente de sua casa, uma moradora forjou sinalização horizontal impeditiva de estacionamento e colocou placas proibindo o estacionamento além de deixar bilhetes ríspidos para os que lá estacionavam, ainda que o acesso rebaixado de sua garagem estivesse sendo respeitado.
} 
Com o advento da promulgação desta Lei, acirram-se os ânimos entre os que defendem as alterações e os que querem preservar o caráter monofuncional do bairro. A primeira década do Séc. XXI é um período, onde as tensões entre os dois grupos atingem o ponto mais alto: Se por um lado já há muito se tem certeza da mudança no perfil do bairro, alguns ainda insistem em se apegar ao tradicionalismo elitista de suas origens, citando inclusive que o Decreto de aprovação do arruamento (de 1946, como vimos) garantiria que seu uso deveria permanecer estritamente residencial unifamiliar.

É um período de ebulição neste embate entre os dois grupos, que se utilizam da coleta de abaixo-assinados, e de diversos meios de pressão sobre o Executivo e - Legislativo Municipais, para tentar fazer valer seus pontos de vista. Reportagens do jornal Correio Popular, de 24/08/2000 e 12/09/2000, que reproduzimos nos anexos dão conta deste acirramento nos ânimos.

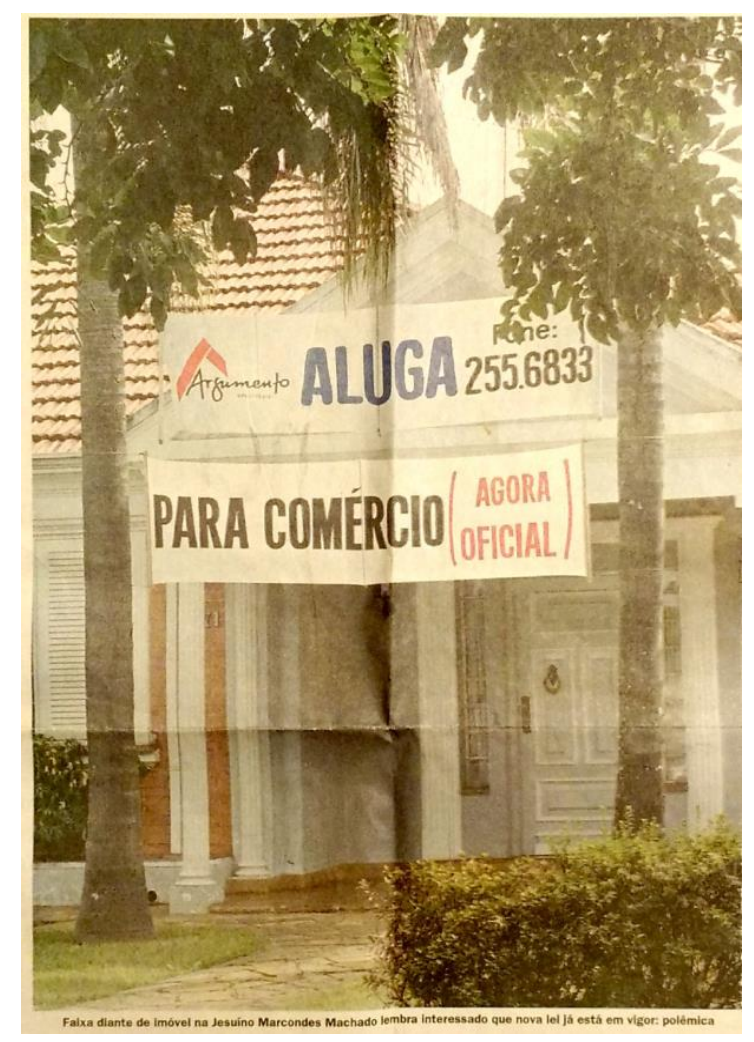

Figura 55: Foto ilustrando reportagem publicada em 26/07/2000 sobre a polêmica relativa à entrada em vigor da Lei 10.566/00. Fonte: Jornal Correio Popular. Acervo da Família Brásio.

\footnotetext{
${ }^{95}$ Trecho da fala do Vereador Antonio Rafful, retirado da transcrição da audiência pública de 14/03/2000, constante nos autos do processo protocolado sob $n^{\circ} 37.033 / 00$ e que trata do Projeto de Lei $n^{\circ} 31 / 2000$ e que viria resultar na promulgação da Lei $\mathrm{n}^{\mathrm{o}}$ 10.566/00. Fonte: Arquivo da Câmara Municipal. A transcrição dos principais trechos desta audiência está nos anexos.
} 
Inicialmente, a S.B.N.C. busca de todas as maneiras a revogação da Lei 10.566/00, inclusive patrocinando um projeto de autoria do vereador Romeu Santini visando a sua revogação ( $P L n^{\circ} 588 / 00$ ) que, contudo, não avança, mas provoca acirrados debates no Legislativo Municipal. Ocorre que 2000 foi ano de eleições municipais e, provavelmente, não houve vontade por parte da classe política, de desagradar nenhum dos dois grupos.

Assiste-se neste momento uma divisão clara entre os proprietários de imóveis no bairro, muitos defendendo inclusive a mudança de zoneamento de todo o bairro para Z-9, o que possibilitaria inclusive a verticalização em múltiplos pavimentos para fins residenciais (Padrões HMV-1 e HMV-2) e usos comerciais de médio porte com edificações tipo CSE-1 que possibilitam até 4 pavimentos comerciais (térreo, sobreloja, e mais dois pavimentos-tipo).

Sem encontrar respaldo no poder legislativo, a S.B.N.C. procura outras alternativas, para impedir a instalação de comércio e serviços na Nova Campinas e recorre então, à ideia do tombamento do bairro, seguindo o exemplo do que ocorreu em São Paulo com o Pacaembu e os Jardins, visando a prevalecer deste modo, sua concepção sobre a ocupação do bairro.

Em 30/09/2002, a S.B.N.C. protocola solicitação ao CONDEPACC visando ao "tombamento do loteamento Nova Campinas nos moldes do que já ocorreu em São Paulo, especialmente nos denominados Jardins".

Alegava para tanto que:

"Trata-se de um loteamento concebido e projetado como estritamente residencial singular conforme está expresso em seu memorial descritivo e materializado na concep̧̧ão urbanistica dada ao projeto, o que se evidencia de modo claro pela largura e o traçado sinuoso de suas ruas; pela disposição e pela quantidade de suas áreas de praças, hoje densamente arborizadas [...] Além disso, há dispositivo expresso no memorial, designando apenas duas de suas quadras, as de $n^{o s} 02$ e 10, onde será permitido o uso comercial [...].

No entanto, de uns tempos a esta data, surgiram iniciativas de uns poucos proprietários, não mais moradores do bairro, pretendendo flexibilizar a lei 
de uso e ocupação do solo para a Nova Campinas, para permitir a instalação de comércio em algumas de suas ruas, o que acabou sendo consagrado em manobra legislativa pouco ortodoxa, na promulgação da Lei $n^{o} 10.566 / 00[\ldots]$.

A promulgação desta lei, cuja tramitação ocorreu à revelia desta Sociedade de Bairro, provocou a imediata reação dos moradores que, em sua maioria, liderados por esta Sociedade, iniciaram uma intensa campanha contra esta absurda e inoportuna lei, promovendo o anexo abaixo assinado, encaminhado ao então Prefeito municipal e ao presidente da Câmara Municipal [...].

Não é admissível que o bairro que foi projetado, tendo por premissa básica de ser estritamente residencial, partindo de um conceito urbanistico que prioriza moradia, que assim foi aprovado e implantado e se desenvolveu ao longo do tempo, mantendo e aprimorando o conceito de bairro jardim, venha a ser degradado, por uma mudança pontual de zoneamento, que veio a permitir o uso comercial indiscriminado, em algumas de suas ruas, ferindo mortalmente a sua concepção urbanística original [...].

Entendemos que esta medida se impõe para se garantir a preservação do projeto urbanístico do bairro, o meio ambiente, a flora e a fauna nele existentes, evitando-se os graves problemas de trânsito, de poluição sonora e visual, decorrentes das diversas atividades comerciais que passaram a ser permitidas pela citada lei, e por outras, ainda mais perniciosas, que poderão surgir ${ }^{, 96}$.

O CONDEPACC examina o pedido e solicita maiores esclarecimentos, informando à S.B.N.C. através do Ofício n²9/04 de 23/04/2004 para que "fundamentasse o pedido de tombamento, levando-se em conta que o instituto do tombamento não pode ser utilizado de forma a substituir o zoneamento, o plano diretor e outros instrumentos legais".

Em 15/10/2004 a S.B.N.C. volta à carga, desta vez alegando outras razões adicionais, especialmente uma suposta singularidade do bairro na cidade de Campinas, como único bairro jardim remanescente, e sua autoria, do citado Eng. ${ }^{\circ}$ Jorge de Macedo Vieira que havia trabalhado na Companhia City em seu início de

\footnotetext{
${ }^{96}$ Pedido de abertura de estudo de tombamento do Bairro Nova Campinas. Protocolo n ${ }^{\circ}$ 02/10/4.378 datado de 30/09/2002. Fonte: Arquivos da CSPC.
} 
carreira.

No afã de justificar tecnicamente o tombamento, foi encaminhado ao conselho um estudo bastante superficial feito por aluna de graduação em Arquitetura da UNICAMP, intitulado "O Engenheiro Jorge de Macedo Vieira e o bairro-jardim da Nova Campinas" sendo juntado aos autos. Este estudo foi apresentado em reunião do CONDEPACC de 09/12/2004, na qual se deliberou pelo tombamento "ad referendum" (pois não houve quórum nesta reunião) do bairro.

Em abril de 2005 ocorreu nova votação, e considerando-se a deliberação pelo tombamento como referendada, desta feita somente se decidiu a respeito do teor da resolução de tombamento, em relação ao perímetro abrangido (que incluiu a já totalmente modificada parcela lindeira ao Cambuí) além de estipular regulamentos que diferiam inclusive, daqueles que alegava pretender preservar, como uma taxa de permeabilidade de $50 \%$ do lote, conflitando inclusive com a taxa de ocupação permitida na LUOS que é de $65 \%$.

Em maio de 2005, entidades lideradas pela HABICAMP (Associação das empresas do setor imobiliário de Campinas e região) e que incluía também o CRECI, o Sindicato dos Corretores de Imóveis, a ACIC (Associação Comercial e Industrial de Campinas), o SINDUSCON e o CIESP, protocolaram recurso através do protocolo $\mathrm{n}^{\circ}$ 05/10/23.431 de 04/05/2005, contestando as disposições do tombamento e solicitando sua revogação, dado que ainda não tinha sido promulgado pelo Executivo Municipal.

O recurso é encaminhado para análise da SEPLAMA - Secretaria Municipal de Planejamento, Desenvolvimento Urbano e Meio Ambiente que se manifesta favorável ao acolhimento do mesmo, dadas as várias inconsistências da resolução de tombamento:

..."Conclusão:

A Resolução elaborada, além de não se ater ao perímetro que ainda conserva as características originais definindo outra configuração, introduz parâmetros divergentes daqueles que representam as características a serem mantidas e, de um modo geral, conflita com a legislação urbanística em vigor, conforme se demonstrou.

Desta forma, a resolução $n^{\circ} 61$ de 14 de abril de 2005 inova ao legislar 
complementarmente à legislação urbanística criando parâmetros diversos daqueles que pretende preservar".

Fonte: C.S.P.C.: Processo de tombamento da Nova Campinas (Parecer técnico da SEPLAN sobre recurso interposto)

A Secretaria de Assuntos Jurídicos esposa entendimento semelhante ao da SEPLAMA e também aponta inconsistências jurídicas no rito de tombamento (quórum das deliberações) e na própria motivação afirmando que "desde o início do processo houve certa confusão entre o objetivo de proteger um bem histórico e o objetivo de impor restrições ao zoneamento" e deste modo opina pelo acolhimento do recurso.

Pela primeira (e única) vez na história um Prefeito Municipal de Campinas faz uso de suas prerrogativas em relação às deliberações do CONDEPACC e em $26 / 08 / 2005$, cancela um tombamento, remetendo o processo de volta à CSPC, órgão técnico da Secretaria Municipal de Cultura que subsidia as deliberações do CONDEPACC, para continuidade dos estudos em uma situação em que permanece inalterada até a presente data.

O assunto (tombamento) paira desde então como uma espécie de fantasma no CONDEPACC, pois um novo estudo não foi concluído e tampouco foi proposto o seu arquivamento (até dezembro de 2015).

Além destas demandas que indicam claramente um conflito de usos, e que resultaram em processos de substituição de usos nas zonas residenciais, pelo menos nas vias de maior tráfego, a pressão imobiliária começa a se manifestar mais claramente.

Em 2007, com o surge um edifício de escritórios de 18 andares na Av. José de Sousa Campos (trecho zoneado como Z-12) que passa a abrigar o Fórum trabalhista Desembargador José Teixeira Penteado. (figura 57)

Em 2011 a Justiça do Trabalho adquire o edifício e se instala definitivamente. Esta atividade pode ser considerada um polo atrator e gerador de fluxo, aumentando a demanda por vagas de estacionamento e atraindo serviços relacionados nos quarteirões próximos, escritórios de advocacia, despachantes, restaurantes, dentre outros. 

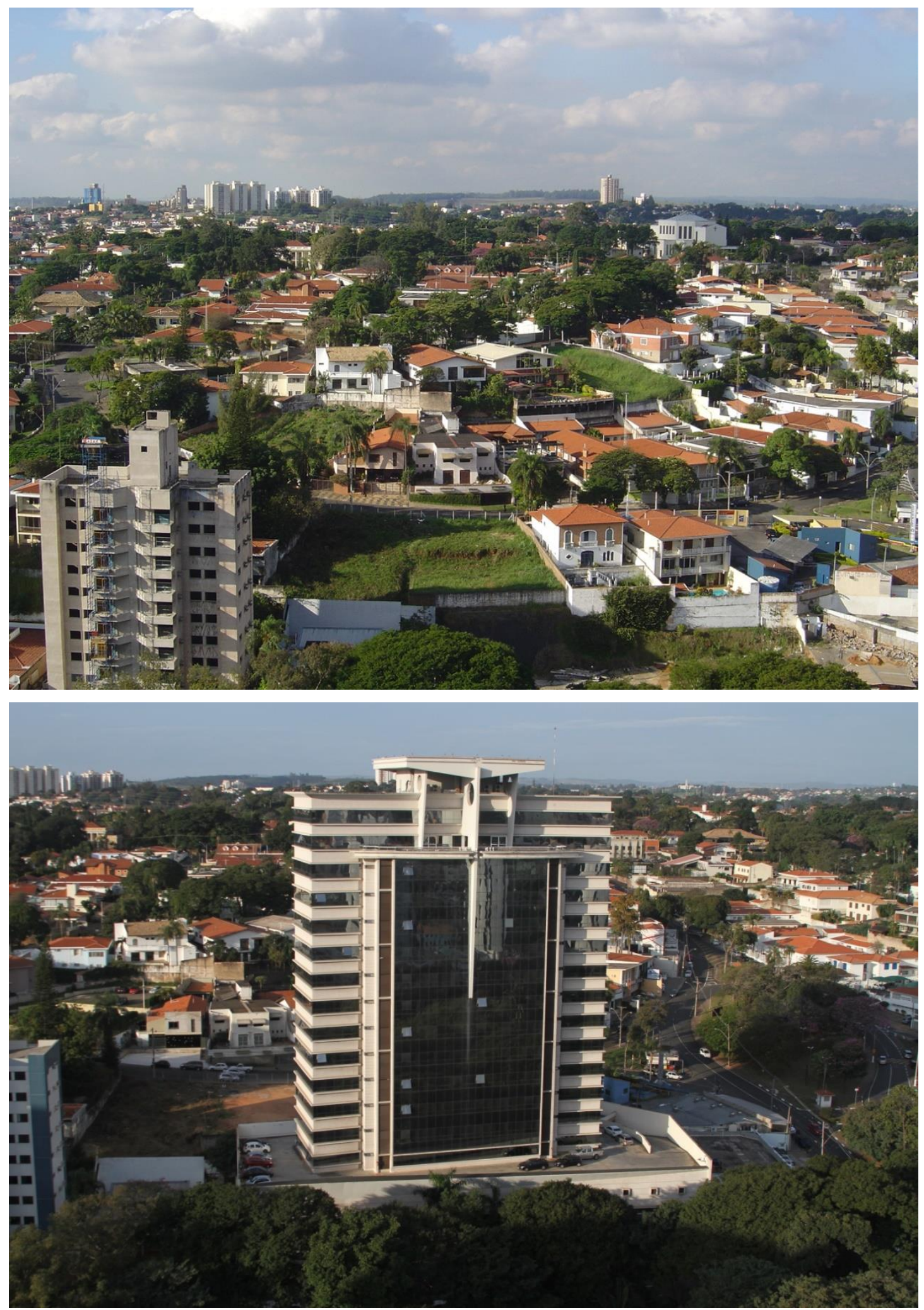

Figuras 56 e 57: Fotos tiradas do heliponto do Hotel Vitória, mostrando a demolição de imóveis (em 2004) que dariam lugar ao prédio do TRT e o edifício nos dias atuais (2015). Fontes: Arquivo da CSPC (foto de 2004) e acervo do autor. 
Como não se conseguiu atualizar a LUOS, e a data máxima de Habite-se prevista pela Lei $n^{\circ} 10.566 / 00$ para atendimento aos critérios de flexibilização não atendia mais às necessidades, criou-se em 2014 mais uma lei de flexibilização (Lei Complementar $\left.n^{\circ} 62 / 2014\right)$ visando acomodar as dinâmicas do setor terciário aos interesses dos proprietários de imóveis situados em zonas exclusivamente residenciais, mas mantendo-se o mesmo padrão de suas predecessoras, isto é, com as restrições quanto ao porte e liberando apenas algumas categorias de usos. Apesar de flexibilizar o uso de edificações residenciais já existentes, continua não permitindo que novas construções se utilizem de tipologias adequadas às diversas atividades terciárias. Esta Lei inova pela sua abrangência, pois além de atingir toda a área zoneada da cidade como Z-1, Z-2, Z-3, Z-5, Z-6 e Z-7( tal como suas antecessoras), também cita nominalmente 113 vias da cidade e rompe uma espécie de tabu, ao alcançar pela primeira vez alguns bairros protegidos pela alínea d) do Inciso III do Art. 27 da LUOS ( Jardim Guanabara; Jardim Santa Genebra (parte I); Jardim Planalto e Nova Campinas).

No caso da Nova Campinas, o Projeto de Lei Complementar enviado à Câmara ressalva que esta flexibilização será somente para a Av. Jesuíno Marcondes Machado e Rua Eng. ${ }^{\circ}$ Carlos Stevenson (alguns usos comerciais e de serviços) e Rua Dr. Hermas Braga (alguns usos de serviços), além é claro da já estabelecida Av. Moraes Salles, onde libera uma maior gama de usos e estabelecimentos de médio porte.

O envio deste Projeto de Lei Complementar serviu como "guarda-chuvas" para uma profusão de emendas", 17 no total, propostas por diversos vereadores que aproveitaram a ocasião para atender a interesses específicos. Afinal, como já comentamos, desde o advento do Plano Diretor de 2006 (Lei Complementar n¹5/2006) estão impedidos de propor qualquer proposta de alteração de zoneamento, prática quase que corriqueira nas legislaturas anteriores.

O projeto original libera as atividades de caráter local e pequeno porte nas Zonas residenciais (Z-1 a Z7) e para as determinadas vias definidas em seu Artigo $8^{\circ}$, libera atividades de âmbito geral, de pequeno porte. Para que tenhamos uma ideia da extensão destas modificações basta dizer que o PLC original propunha a alteração para 23 vias no Artigo $8^{\circ}$ e a Lei aprovada com as emendas inclui no mesmo Artigo 113 vias. 
No caso da Nova Campinas, os Vereadores incluíram através destas emendas as Ruas Dr. José Ferreira de Camargo, Rafael Andrade Duarte, Arthur Bernardes e Gustavo Armbrust. O interessante desta inclusão é que as restrições originais que atingiam a Av. Jesuíno Marcondes Machado, a Rua Hermas Braga e a Rua Carlos Stevenson aqui foram "esquecidas" e estas vias que possuem trânsito mais calmo e leito carroçável mais estreito (pois não se conectam com vias externas ao bairro), acabaram ficando muito mais permissivas no que tange à possibilidade de obtenção de Alvará de Usos do que as vias mais importantes do bairro.

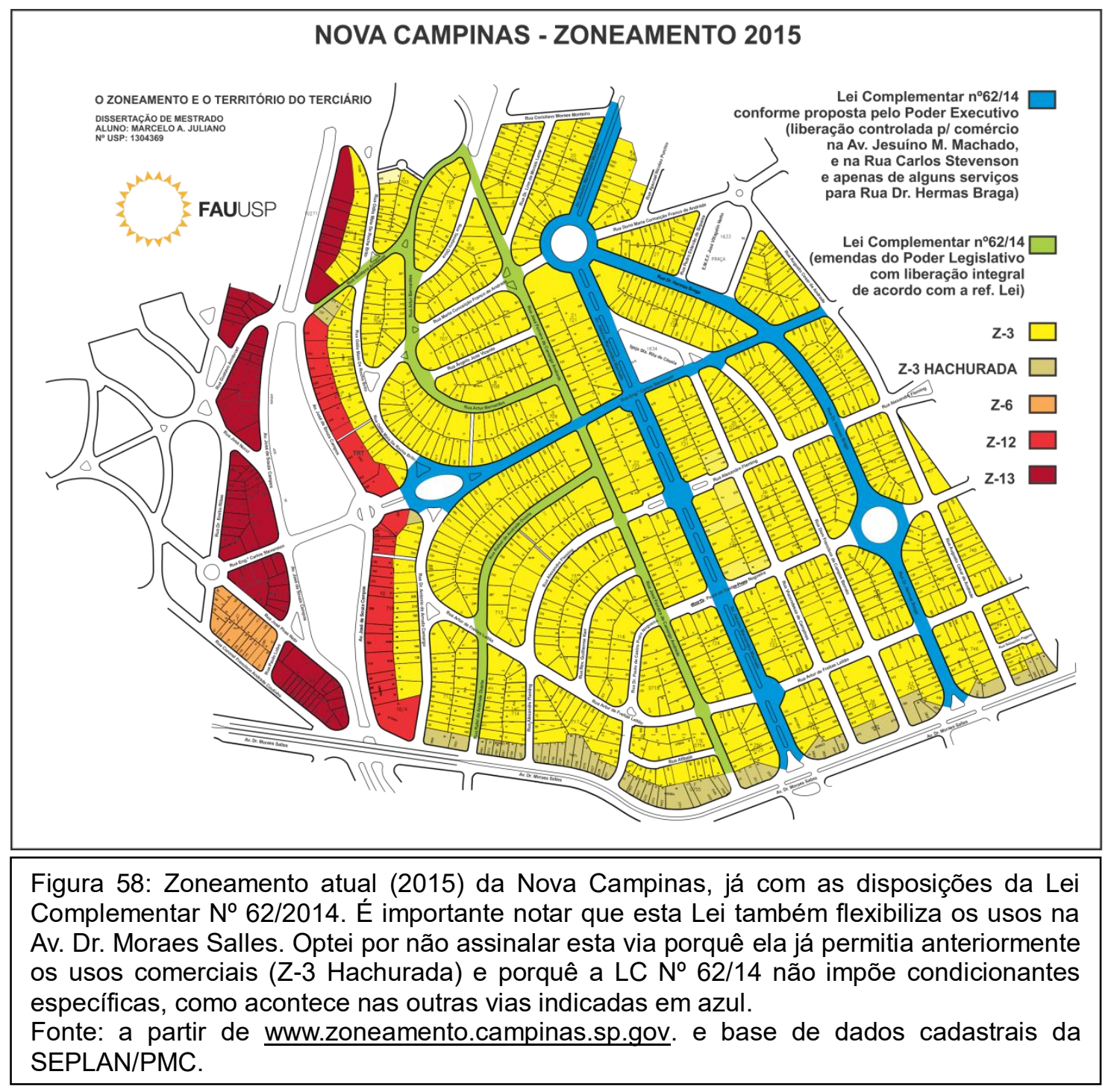




\section{4 - Levantamento de usos e conclusões:}

Executamos em fevereiro de 2015, um levantamento atualizado de usos na área da Nova Campinas que possibilitou a elaboração de um mapa que analisou todo o perímetro original do loteamento:

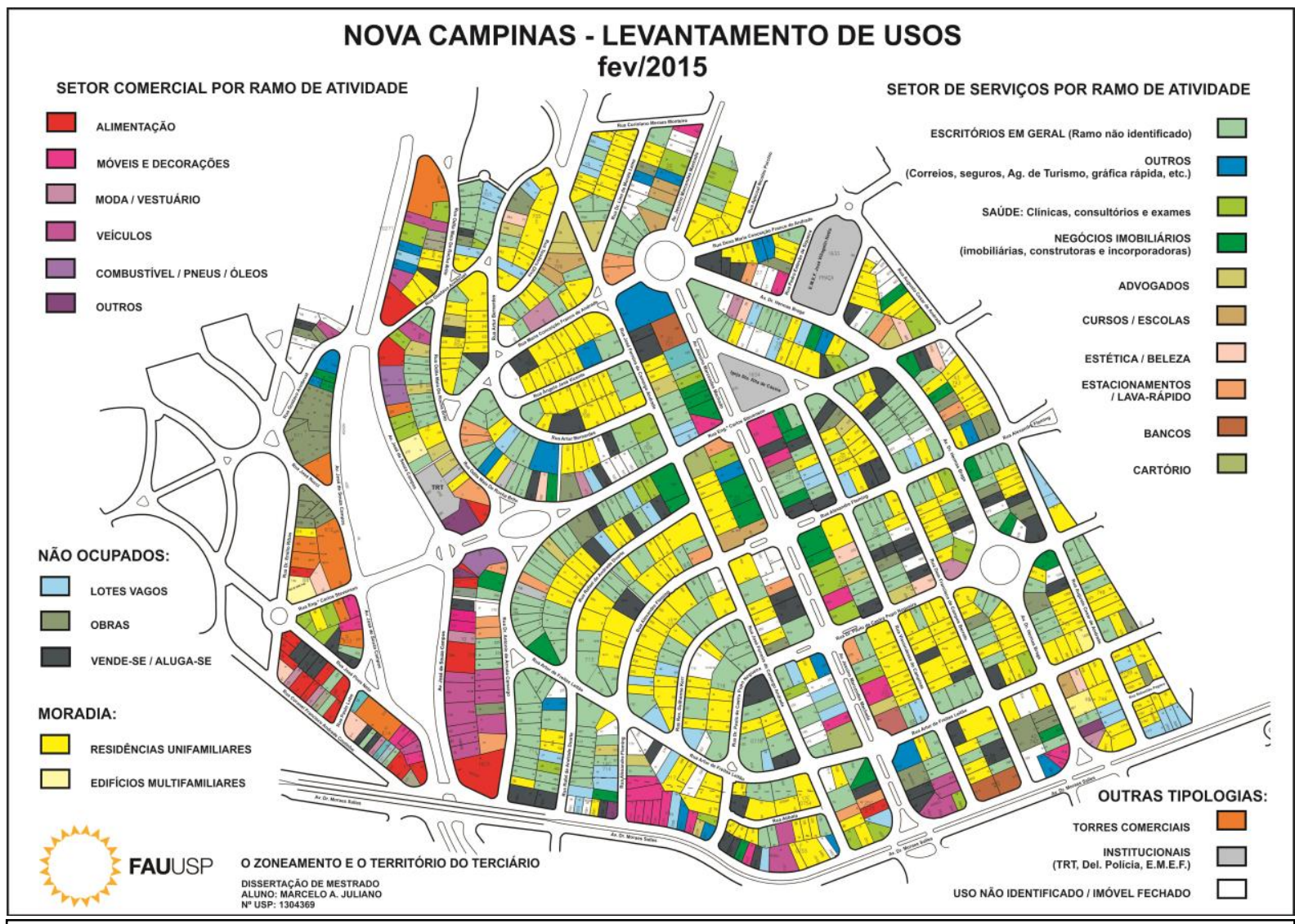

Figura 59: Levantamento de Usos na Nova Campinas. Fonte: levantamento de campo executado em Fev/2015, a partir de base cadastral do DIDC / SEPLAN.

\section{CRITÉRIOS ADOTADOS:}

1- Os imóveis de tipologia torre comercial de escritórios foram contabilizados como um só, na categoria de serviços.

2 - Levou-se em consideração os dados do cadastro para definir os números de imóveis, mesmo quando visivelmente unificados, deste modo lotes já unificados no cadastro foram contabilizados uma única vez, enquanto lotes cujo cadastro ainda permanece como lotes autônomos foram contabilizados um a um, exceto nos casos de obras de que dispomos de dados mais atualizados do que a PRC que é de 2010, através do sítio do zoneamento / SEPLAMA:

zoneamento.campinas.sp.gov.br

3 - Os imóveis institucionais, situados dentro das quadras (a Torre do TRT e os dois imóveis ocupados pela SSP/SP) foram contabilizados como do setor de serviços.

Os dados colhidos foram inseridos em uma planilha, permitindo uma leitura da situação do uso real do solo na Nova Campinas.

É possível ver claramente que na área dita como exclusivamente residencial, temos uma grande ocupação de imóveis com usos de serviços, e uma significativa 
quantidade de terrenos vazios, além de vários imóveis para locação ou venda.

Pode-se observar que praticamente $50 \%$ da área original está ocupada pelo terciário, mesmo que a legislação somente permita estes usos na área situada na margem esquerda do córrego Proença, nas Avenidas José de Sousa Campos e Moraes Salles, na Av. Jesuíno Marcondes Machado e nas Ruas Carlos Stevenson e Hermas Braga (além das outras quatro vias que foram também incluídas através de emendas à LC Nº 62/2014).

\begin{tabular}{|c|c|c|c|c|c|c|c|c|c|}
\hline \multicolumn{10}{|c|}{ LEVANTAMENTO SIMPLIFICADO DE USOS - NOVA CAMPINAS FEV/2015 } \\
\hline $\begin{array}{c}\text { № Quarteirão } \\
\text { (Levantamento) }\end{array}$ & \begin{tabular}{|c|} 
№ Quarteirão \\
(Cadastro Mun.)
\end{tabular} & $\begin{array}{l}\text { Imóveis com uso } \\
\text { Comercial }\end{array}$ & $\begin{array}{l}\text { Imóveis com uso de } \\
\text { Serviços }\end{array}$ & Imóveis Residenciais & $\mid$\begin{tabular}{|} 
Imóveis com faixas de \\
"Aluga-se / Vende-se"
\end{tabular} & Lotes Vazios & Imóveis em obras & $\begin{array}{c}\text { Usos não } \\
\text { identificados ou } \\
\text { imóvel fechado s/ } \\
\text { anúncio } \\
\end{array}$ & $\begin{array}{l}\text { TOTAL DE } \\
\text { IMÓVEIS }\end{array}$ \\
\hline 1 & 1 & 10 & 4 & 0 & 3 & 0 & 0 & 0 & 17 \\
\hline 2 & 613 & 2 & 7 & 1 & 2 & 0 & 0 & 0 & 12 \\
\hline 3 & 614 & 8 & 8 & 0 & 2 & 0 & 0 & 0 & 18 \\
\hline 4 & 710 & 22 & 6 & 0 & 0 & 2 & 1 & 2 & 33 \\
\hline 5 & 712 & 0 & 15 & 3 & 2 & 0 & 0 & 1 & 21 \\
\hline 6 & 714 & 1 & 12 & 2 & 1 & 3 & 0 & 2 & 21 \\
\hline 7 & 717 & 8 & 6 & 5 & 1 & 2 & 0 & 4 & 26 \\
\hline 8 & 755 & 3 & 5 & 8 & 3 & 1 & 0 & 1 & 21 \\
\hline 9 & 754 & 0 & 2 & 4 & 1 & 0 & 0 & 0 & 7 \\
\hline 10 & 725 & 1 & 7 & 3 & 1 & 0 & 0 & 1 & 13 \\
\hline 11 & 734 & 3 & 5 & 1 & 2 & 0 & 1 & 0 & 12 \\
\hline 12 & 738 & 0 & 5 & 4 & 2 & 0 & 0 & 0 & 11 \\
\hline 13 & 742 & 2 & 3 & 2 & 0 & 0 & 3 & 2 & 12 \\
\hline 14 & 746 & 2 & 4 & 6 & 0 & 2 & 0 & 0 & 14 \\
\hline 15 & 749 & 0 & 0 & 10 & 0 & 5 & 1 & 0 & 16 \\
\hline 16 & 748 & 0 & 5 & 5 & 0 & 0 & 1 & 0 & 11 \\
\hline 17 & 745 & 0 & 7 & 8 & 1 & 0 & 0 & 1 & 17 \\
\hline 18 & 741 & 0 & 6 & 10 & 1 & 0 & 1 & 0 & 18 \\
\hline 19 & 737 & 0 & 4 & 11 & 2 & 0 & 0 & 0 & 17 \\
\hline 20 & 733 & 1 & 7 & 6 & 0 & 1 & 0 & 0 & 15 \\
\hline 21 & 724 & 1 & 7 & 1 & 0 & 3 & 0 & 4 & 16 \\
\hline 22 & 718 & 0 & 4 & 3 & 2 & 1 & 0 & 0 & 10 \\
\hline 23 & 716 & 0 & 7 & 7 & 0 & 1 & 0 & 2 & 17 \\
\hline 24 & 715 & 0 & 7 & 13 & 0 & 3 & 0 & 1 & 24 \\
\hline 25 & 713 & 0 & 12 & 12 & 1 & 0 & 0 & 0 & 25 \\
\hline 26 & 711 & 0 & 26 & 7 & 4 & 3 & 1 & 0 & 41 \\
\hline 27 & 747 & 0 & 0 & 1 & 0 & 2 & 0 & 0 & 3 \\
\hline 28 & 744 & 0 & 7 & 3 & 3 & 0 & 2 & 2 & 17 \\
\hline 29 & 740 & 1 & 6 & 7 & 1 & 0 & 1 & 1 & 17 \\
\hline 30 & 736 & 0 & 8 & 2 & 4 & 0 & 1 & 2 & 17 \\
\hline 31 & 732 & 1 & 10 & 1 & 1 & 0 & 0 & 0 & 13 \\
\hline 32 & 723 & 0 & 3 & 4 & 2 & 0 & 1 & 3 & 13 \\
\hline 33 & 743 & 0 & 5 & $\begin{array}{l}4 \\
7\end{array}$ & 1 & 0 & 4 & 2 & 19 \\
\hline 34 & 739 & 0 & 12 & 3 & 2 & 1 & 0 & 2 & 20 \\
\hline 35 & 735 & 0 & 3 & 7 & 3 & 1 & 1 & 0 & 15 \\
\hline 36 & 731 & 2 & 9 & 1 & 4 & 0 & 1 & 0 & 17 \\
\hline 37 & 722 & 0 & 7 & 4 & 0 & 0 & 0 & 0 & 11 \\
\hline 38 & 730 & 0 & 6 & 6 & 1 & 0 & 0 & 5 & 18 \\
\hline 39 & 728 & 1 & 12 & 6 & 1 & 3 & 0 & 3 & 26 \\
\hline 40 & 721 & 1 & 11 & 1 & 1 & 2 & 0 & 2 & 18 \\
\hline 41 & 709 & 0 & 22 & 5 & 3 & 1 & 1 & 4 & 36 \\
\hline $\begin{array}{l}41 \\
42\end{array}$ & 702 & 8 & 18 & 3 & 0 & 2 & 0 & 0 & 31 \\
\hline 43 & 727 & 1 & 4 & 4 & 3 & 0 & 1 & 2 & 15 \\
\hline 44 & 708 & 0 & 3 & 11 & 1 & 0 & 0 & 0 & 15 \\
\hline 45 & 707 & 0 & 2 & 12 & 1 & 0 & 0 & 1 & 16 \\
\hline 46 & 726 & 0 & 4 & 6 & 0 & 0 & 0 & 0 & 10 \\
\hline 47 & 720 & 1 & 14 & 3 & 0 & 0 & 1 & 5 & 24 \\
\hline 48 & 719 & 0 & 6 & 11 & 0 & 2 & 0 & 0 & 19 \\
\hline 49 & 705 & 0 & 3 & 7 & 0 & 2 & 1 & 0 & 13 \\
\hline 50 & 703 & 0 & 7 & 1 & 1 & 3 & 1 & 0 & 13 \\
\hline 51 & 701 & 5 & 6 & 4 & 1 & 1 & 0 & 0 & 17 \\
\hline 52 & 706 & 1 & 10 & 5 & 0 & 0 & 0 & 1 & 17 \\
\hline 53 & 704 & 0 & 4 & 10 & 2 & 0 & 0 & 0 & 16 \\
\hline 54 & 611 & 0 & 5 & 0 & 0 & 0 & 6 & 0 & 11 \\
\hline 55 & 612 & 1 & 3 & 2 & 0 & & 1 & 0 & 7 \\
\hline 56 & 610 & 1 & 0 & 0 & 1 & & 2 & 4 & 8 \\
\hline \multicolumn{2}{|c|}{ TOTAIS POR CATEGORIA: } & 88 & 391 & 269 & 68 & 47 & 34 & 60 & 957 \\
\hline \multicolumn{2}{|c|}{ TOTAIS PERCENTUAIS } & $9,20 \%$ & $40,86 \%$ & $28,11 \%$ & $7,11 \%$ & $4,91 \%$ & $3,55 \%$ & $6,27 \%$ & $100,00 \%$ \\
\hline
\end{tabular}

Figura 60: Modelo de planilha utilizada para tabular os dados colhidos em campo referentes ao uso real das edificações em fev/2015. Foram analisados 957 imóveis (com as edificações de múltiplos pavimentos contando como um único, de acordo com os critérios explicados na figua 51), pertencentes a 56 quarteirões diferentes, que compõem o perímetro do loteamento aprovado em 1946 


\section{Levantamento de usos reais Nova Campinas - fev/2015}

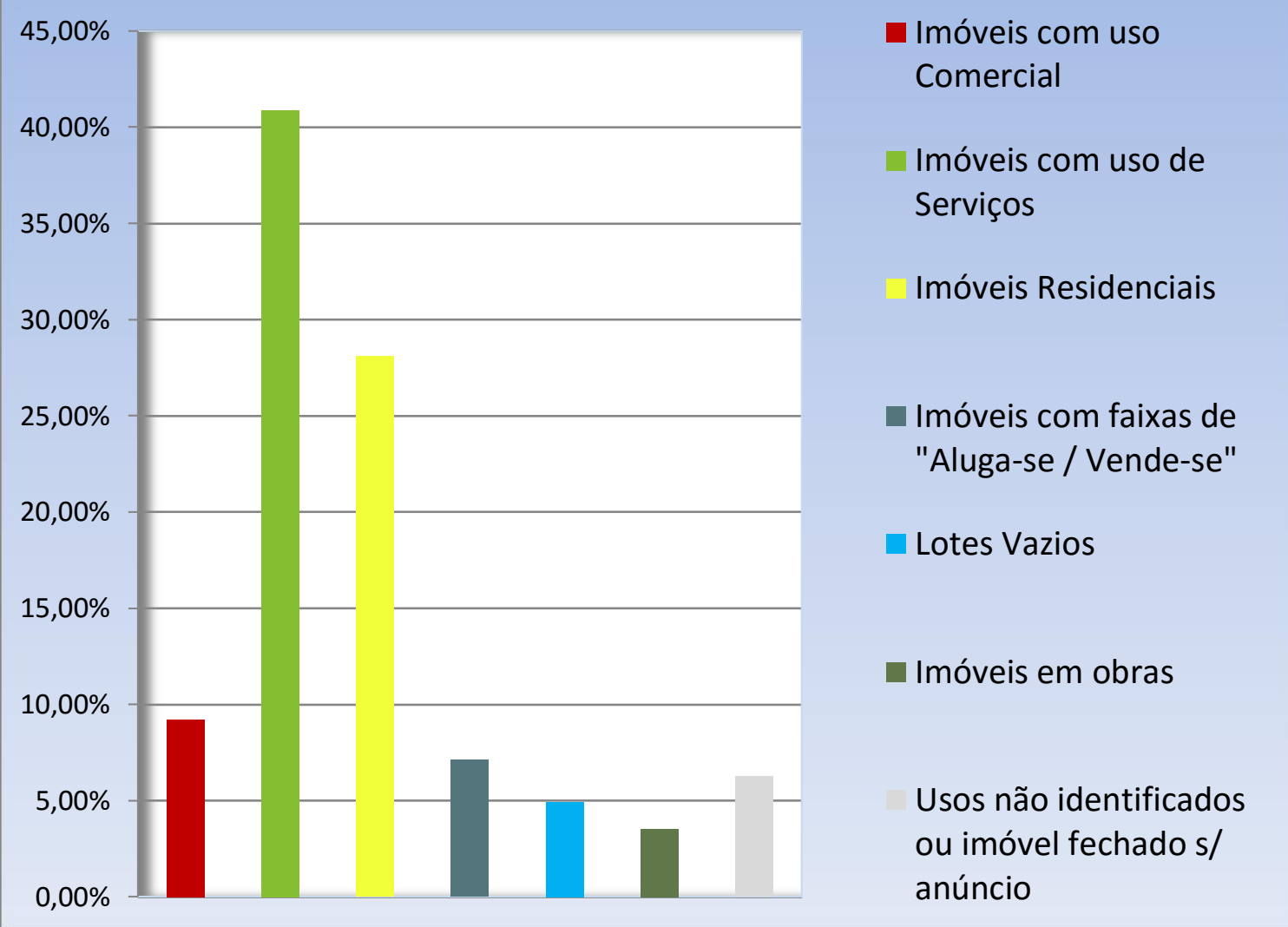

Figura 61: Gráfico extraído da planilha de dados (figura 58), onde podemos observar que apenas 269 imóveis $(28,11 \%)$ permanecem com o uso residencial. Fonte: Levantamento de campo em fevereiro de 2015.

Diante das mudanças urbanas das últimas décadas e a despeito do pretenso imobilismo no embasamento teórico da LUOS o terciário sempre encontra mecanismos de adaptação para sua inserção no território, seja à margem da Legislação, ou se valendo de uma conjugação de interesses com os dos proprietários de imóveis para modificá-la (ainda que de forma pontual e muitas vezes pouco efetiva, do ponto de vista da legalização de suas atividades).

No caso da Nova Campinas, o que se assistiu foi uma ocupação progressiva pelo setor terciário (pelo setor de serviços majoritariamente) dos imóveis cuja atratividade como moradia foi se esvaindo ao longo dos anos.

Ainda assim, há uma enorme dificuldade em se abandonar o discurso da segregação de usos. Mesmo com a Legislação totalmente retalhada e alterada, com as leis de flexibilização que citamos, permanece em vigor a LUOS cujos princípios declarados para a maior parcela do território é justamente a separação de usos. As 
mudanças acabam sendo muitas vezes inócuas, ao permitir apenas determinados usos que muitas vezes não são os estabelecidos naqueles locais que se pretende liberalizar.

Mas talvez as piores consequências para a qualidade do espaço urbano deste tipo de contorcionismo legislativo, resultam do fato de que estas leis admitirem apenas o uso de imóveis originariamente residenciais, isto é, não se permite nestes zoneamentos a edificação de imóveis das categorias de ocupação comerciais e de serviços (CSE) previstas na LUOS.

Em resumo, uma atividade comercial passa a ser permitida em um imóvel originariamente residencial (mesmo que muito reformado), mas ainda é proibida a construção de edificações adequadas ao uso comercial, o que é especialmente grave se você for proprietário de um lote e não de uma residência. Esta situação coloca ainda mais outro agravante: somente as ocupações comerciais (tipologias CSE) permitem a edificação de subsolos para veículo.

Um dos maiores desafios que a ocupação terciária da Nova Campinas coloca é, sem dúvida, o trânsito no horário comercial. Apesar de contar com ruas largas, o uso de imóveis residenciais adaptados não permite dispor vagas suficientes para funcionários e clientes que acabam estacionando nos dois lados das ruas, estreitando o leito carroçável e diminuindo a capacidade de escoamento da via.

Por outro lado, como o zoneamento, em tese, não foi alterado não se atinge ao objetivo de uma mescla eficiente de usos. Durante o dia o bairro tem todos os problemas de uma área comercial e no período noturno, devido à hoje pequena população residente, o problema de segurança aumenta, com a maioria das vias ficando desertas. Sem uma alteração que permita algum tipo de ocupação residencial de maior densidade, a tendência é que estes problemas cada vez mais se agravem. Temos assim um bairro com inegáveis qualidades ambientais e de desenho urbano, com boa infraestrutura e praticamente colado ao centro da cidade sendo muito degradado, sofrendo com os efeitos de uma legislação inadequada.

Em nossa pesquisa, ficou clara a sensação de que a Nova Campinas hoje é tudo, menos um "bairro exclusivamente residencial". Identificamos que existem três tipos básicos de imóveis: nas ruas onde são permitidos os usos comerciais, os imóveis que estão ocupados têm elementos visíveis de propaganda, como totens e 
luminosos. Quando estão à venda ou para locação fazem questão de frisar a nos anúncios essa condição de uso permitido.

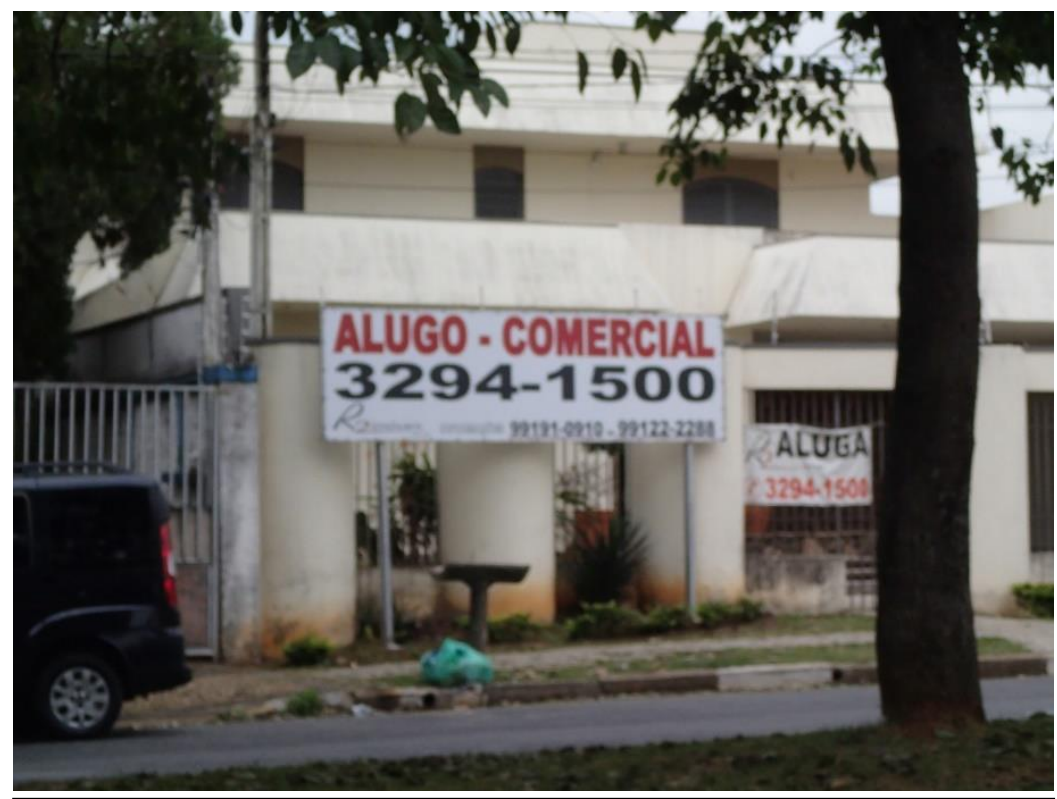

Figura 62: Imóvel para locação à Av. Jesuíno Marcondes, com faixa frisando a legalidade do uso comercial. Fonte Acervo do autor (2015).

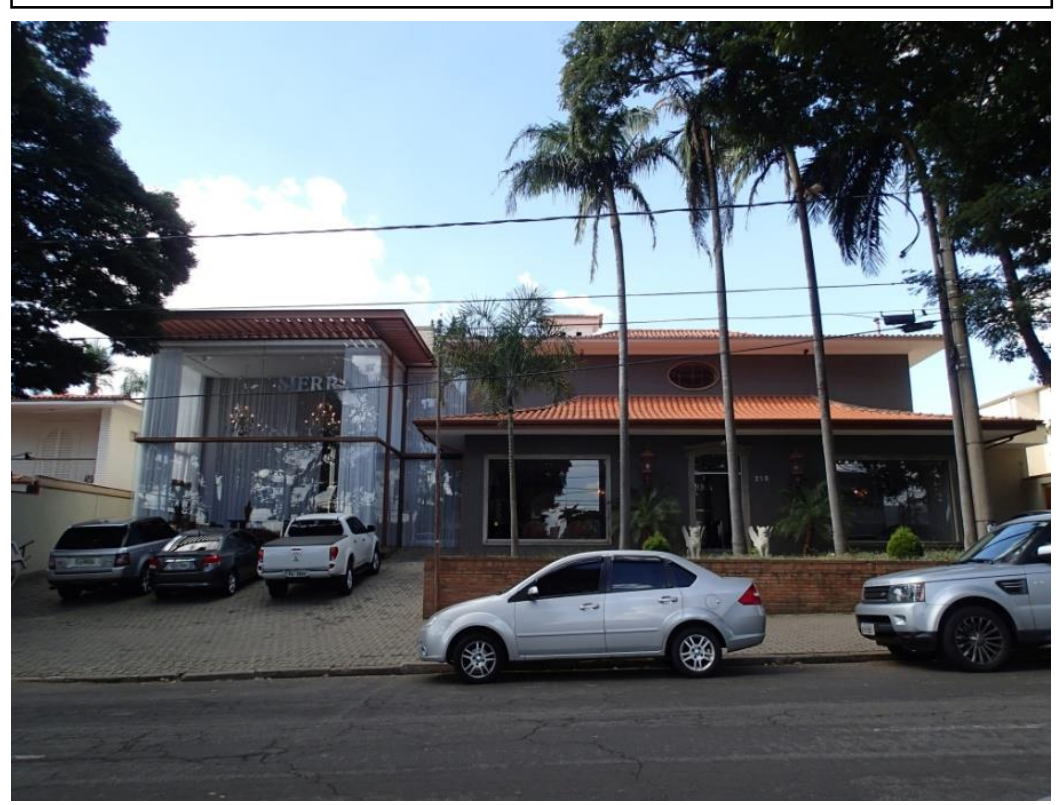

Figura 63: Loja de decoração (mobiliário) à Av. Jesuíno Marcondes. Fonte: Acervo do autor (2015). 


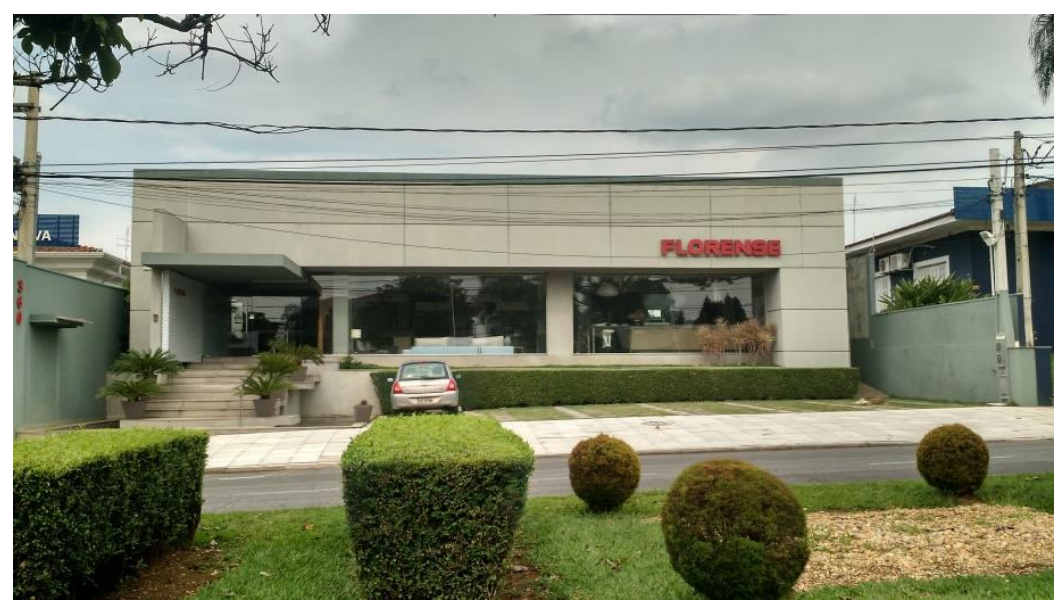

Figura 64: Loja de móveis planejados à Av. Jesuíno Marcondes. Fonte: Acervo do autor (2015).
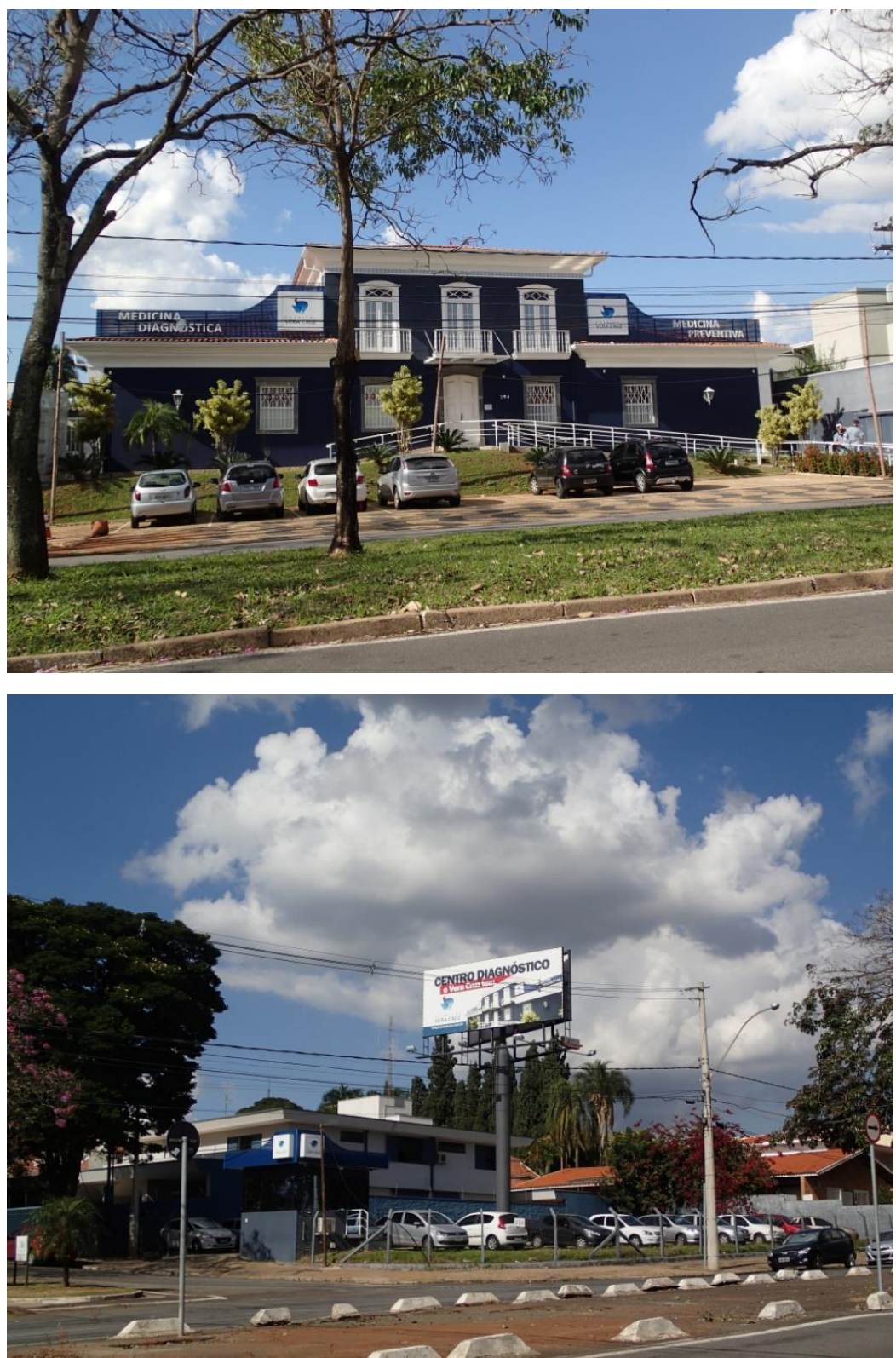

Figuras 65 e 66: Complexo médicodiagnóstico - Av. Jesuíno Marcondes Machado, $n^{\circ} 394$ e respectivo estacionamento, na mesma via na altura do $\mathrm{n}^{\circ}$ 278. Acervo do autor. 
Nas vias não contempladas pela flexibilização, ou quando a atividade exercida não se enquadra nas categorias permitidas, a maior parte dos imóveis com uso comercial se inserem num padrão, que denominamos de: "Imóveis comerciais enrustidos". São imóveis com todas as características de reformas para uso comercial, como elementos arquitetônicos típicos como a abertura de vagas de estacionamento em toda a testada. Mas na maioria dos casos não tem nenhuma placa ou anúncio de identificação, ou quando as possuem são muito tímidas, quase invisíveis.

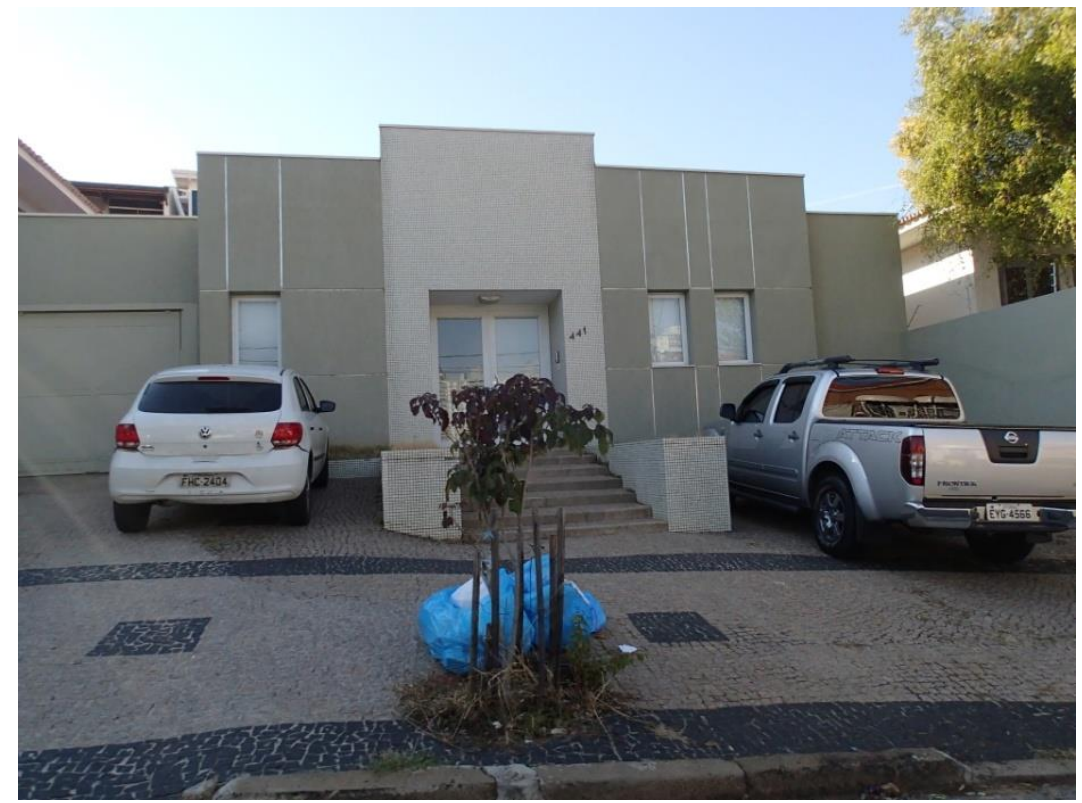

Figura 67:

Imóvel comercial

sem

identificação.

Rua Rafael

Andrade Duarte, $n^{\circ} 441$.

Uso real:

Escritório

comercial de

serviços, na

área de de TI e

Telecomunicaçõ

es. Acervo do

autor (2015).

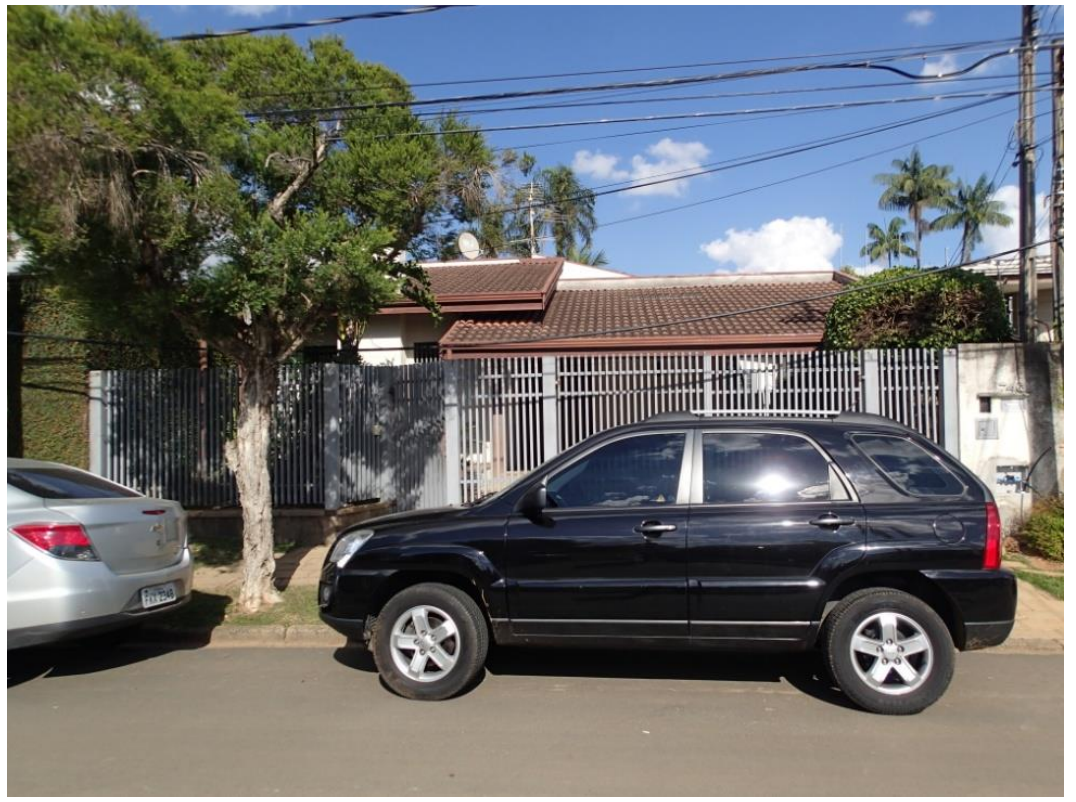

Fig. 68. Imóvel comercial sem identificação.

Rua Sir

Alexandre

Fleming, 476

Uso real:

Escritório de

Arquitetura.

Acervo do autor (2015). 
E por fim há uma grande quantidade de imóveis que está em processo de transformação, com reformas nas fachadas e que com certeza se destinarão a usos não residenciais, aumentando a pressão sobre o tráfego no miolo do bairro.
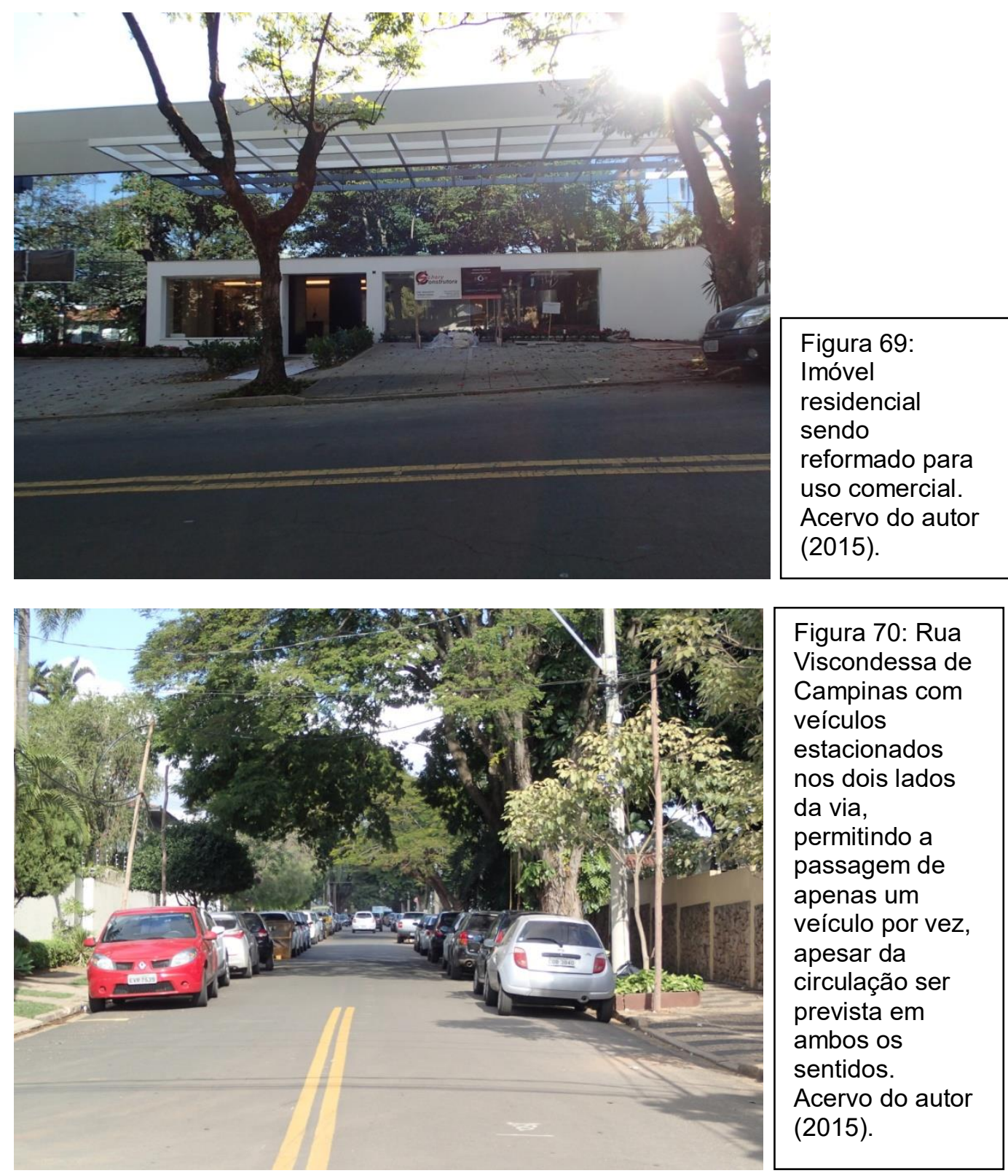

Figura 70: Rua Viscondessa de Campinas com veículos estacionados nos dois lados da via, permitindo a passagem de apenas um veículo por vez, apesar da circulação ser prevista em ambos os sentidos. Acervo do autor (2015).

A partir da década de 1980 as legislações urbanísticas de controle do uso e ocupação do espaço urbano, por seu caráter estático tem representado um papel incompatível com a dinâmica urbana, passando a responder, por meio de sucessivas alterações, ao interesse de grupos específicos. Neste sentido, o exemplo da Cidade de Campinas é esclarecedor, mostrando a dificuldade se de legislar sobre a cidade, tendo como objeto de análise a dinâmica da atividade terciária. 


\section{5- CONSIDERAÇÕES FINAIS:}

O zoneamento se consolidou durante o Século $X X$, como a mais utilizada ferramenta de que as administrações públicas dispuseram para intervir no território. $\mathrm{E}$, como todas as ações sobre o território, tiveram impactos dos mais diversos e nem sempre de acordo com as intenções expressas no discurso. Outro aspecto também presente neste século, no âmbito da gestão urbana, foi a permanência muito forte no imaginário coletivo, da imagem do modelo de cidade ideal moldada pelos preceitos da separação de usos, agravados pela insistência nas baixas densidades, com destaque para o padrão fundiário do lote residencial unifamiliar.

Assim, o presente trabalho procurou mostrar a dificuldade deste instrumento urbanístico de enfrentamento da dinâmica urbana atual, principalmente no que se refere ao entendimento do funcionamento do setor terciário nos grandes centros, marcados pela diversidade destas atividades, pelas novas tecnologias de comunicação, pelo expressivo mercado de consumo, pela mudança de hábitos e comportamentos, pela dificuldade de mobilidade urbana, pelo rearranjo das relações de trabalho, entre outros processos.

Tomado como principal objeto de análise, o processo descrito no Capítulo 4 , sobre o bairro Nova Campinas, reforça nossos argumentos quanto à rigidez das legislações urbanísticas, na forma como as temos utilizado, em dar conta da dinâmica da cidade.

No caso da Nova Campinas o processo de urbanização da cidade tornou o bairro exclusivamente residencial, marcado por residências unifamiliares, cada vez menos atraentes como área residencial, abrindo, por outro lado, o interesse para a sua ocupação por atividades terciárias, aumentando a ociosidade dos imóveis ou estimulando a clandestinidade de usos.

Como, pode ser possível reverter esta tendência de usos exclusivos herdado zoning norte-americano em prol do uso misto?

Conforme Hirt (2014), embora se tenha certeza de que atividades poluidoras e perigosas devam ser mantidas distante dos espaços onde as pessoas moram, trabalham ou tenham seu lazer, a lista de atividades passíveis de se enquadrarem 
nessas categorias de atividades incômodas é bem menor hoje, do que há 100 anos. Cita como exemplos as lavanderias e restaurantes, que não implicam mais nos riscos à saúde e mesmo à vida, como antigamente (incêndio, produtos químicos, etc.), embora outras tantas tenham passado a ser consideradas incômodas.

Outro ponto importante é a crescente proporção de trabalhadores em regime de home office, proporcionada entre outros fatores, pelo avanços nas tecnologias de comunicação e pelas dificuldades na mobilidade urbana. Além disto, toda uma série de atividades não existia, ou se modificaram tanto nas últimas décadas que fica muito difícil enquadrá-las num arcabouço legal pensado há 30 ou 40 anos e que classifica atividades em extensas e estáticas listagens ${ }^{97}$.

De certa maneira, as premissas que moldaram a formação do zoning há 100 anos em busca de uma cidade mais eficiente, segura e saudável, se aplicadas da mesma maneira não lograrão em obter respostas adequadas em um cenário tão diferente como é o das nossas metrópoles atuais e isto se aplica especialmente a sua relação com as dinâmicas do setor terciário.

As leis de flexibilização em Campinas, que expusemos no Capítulo 3, permitiram que, de certa maneira, as atividades terciárias conseguissem uma espécie de "acomodação" com a legislação, mas ficou claro com as sucessivas adaptações, que este processo tem uma validade curta. Além de tudo, a segurança jurídica fica comprometida, já que setores que não aceitam por algum motivo as modificações podem tentar levar o caso para a esfera do Poder Judiciário, assim como o próprio Ministério Público tem atuado nas modificações que alteram a LUOS, alegando geralmente erros de competência entre os Poderes ou ausência de participação Popular $^{98}$.

\footnotetext{
${ }^{97}$ Um caso interessante, já mencionado no Capítulo 3 e que surgiu a partir de entrevistas com funcionários da SEMURB em Campinas é o de representação de próteses cirúrgicas (muitas vezes diminutas, como as otológicas) que são vendidas diretamente aos hospitais e clínicas: A ANVISA classifica esta venda como "atacado", exigindo esta descrição no seu CNAE (Cadastro Nacional de Atividade Econômica) por não ser destinada ao consumidor final. Apesar de poder armazenar todo seu "estoque" em um pequeno armário ele estará impedido de conseguir um Alvará para exercer a atividade em sua residência (comércio atacadista somente é permitido pela LUOS em zona Z-14 ou superior).

${ }^{98}$ Recentemente, em outubro de 2015, o Ministério Público ingressou com uma ADIn (Protocolado no 074.991/15) contra a citada Lei Complementar $n^{\circ} 62 / 2014$, colocando em xeque todos os Alvarás emitidos com base neste diploma. Talvez até por causa desta ADIn, em 11 de janeiro de 2016 foi editada a Lei Complementar $\mathrm{n}^{\circ}$ 142/16, que entendemos vir a corroborar a percepção de que estas modificações se tornam, com o decorrer do tempo, cada vez menos eficazes. Chamado de PROREGEN, o programa por ela instituído libera (segundo cálculos da própria Prefeitura) o Alvará de uso para cerca de 48.000 empresas que estão instaladas em desconformidade com o Zoneamento. A justificativa para esta lei é econômica: segundo a P.M.C. pretende-se com o PRO-REGEN arrecadar pelo menos R \$ 10 milhões a mais em ISSQN. Mais uma vez, repete-se o
} 
Embora se admita que o zoneamento, nos moldes propostos pela LUOS, não esteja dando conta da dinâmica urbana, tendo em vista as inúmeras alterações e "concessões" das legislações complementares, não se abandona o seu discurso. Adapta-se a legislação, mas a incapacidade de romper com o paradigma da separação de usos e da proteção ao uso residencial singular ainda vai continuar a atrapalhar as dinâmicas naturais da cidade e do setor terciário com o qual tem uma relação de origem. É interessante observar que continuamos utilizando as ideias e os instrumentos criados em meados no século $X X$, para resolver problemas do século $X X I$.

Tanto isto é verdade que após a promulgação da Lei Complementar $\mathrm{n}^{0} 142 / 16^{99}$, que criou o PRO-REGEN, programa que concede Alvarás de Uso a empresas em desconformidade com o Zoneamento vigente, o Secretário de Urbanismo fez questão de declarar que "O programa não está alterando a lei de uso do solo, mas apenas flexibilizando o alvará de uso, que passa ser concedido às empresas de baixo risco instaladas em locais proibidos" ${ }^{100}$.

A questão que se coloca, é como seria um instrumento adequado e eficiente para o controle da produção do espaço urbano. Temos acompanhado as discussões sobre a revisão da LUOS e do Plano Diretor em Campinas e em São Paulo. Não se dá a devida atenção à questão da segregação de usos, ao excesso de proteção e estímulo aos enclaves de alta renda e, quando aparece a questão dos usos mistos, no máximo tenta se vender as chamadas fachadas ativas como uma espécie de panaceia, já que provavelmente o incorporador vai utilizá-la para viabilizar seus empreendimentos, mas depois, não há garantias para a ocupação de tanta oferta de área locável relativamente ao setor terciário (comércio e serviços). Fica patente que o debate continua muito mais focado em discutir coeficientes e demais parâmetros que afetam o mercado da incorporação do que na observação da lógica de funcionamento da cidade em seu cotidiano.

Ao longo deste trabalho pudemos observar que o zoneamento se tornou algo que aparenta ser natural, como se sempre tivesse existido, tal a força com que foi

equívoco no que diz respeito à proibição de qualquer ampliação (a questão do tolerado, que já foi citada) e novamente fica-se sujeito a critérios subjetivos de análise:

${ }^{99} \mathrm{O}$ texto completo da Lei está nos anexos.

${ }^{100}$ Entrevista publicada no Jornal Correio Popular de 12/01/2016. 
incorporado em nosso imaginário coletivo. Este contexto dificulta a proposição de qualquer mudança de paradigma, e entendemos ser pertinente, no que se refere aos objetivos desta dissertação, que se reforce aqui a importância de se considerar, no âmbito dos instrumentos de controle da produção do espaço urbano, alguns aspectos relativamente ao setor terciário, em prol de um uso misto condizente com a dinâmica da cidade e com a demanda de seus usuários:

- Evitar fixar em listas estáticas, o rol de atividades relativas ao setor terciário. As necessidades, desejos, e conveniências de grupos e indivíduos, relativamente às atividades terciárias, mudam velozmente;

- Soluções paliativas ou com prazo de validade, para corrigir distorções, como soluções "ad hoc" que legalizam apenas determinados usos até uma data limite, por exemplo, podem acabar por aumentar o fenômeno de clandestinidade que pretendem solucionar, reforçando os padrões de uso que se pretendia esgotar;

- A limitação da dimensão dos usos terciários (área construída) deve ser repensada, pois, nem sempre o tamanho e incomodidade apresentam uma relação diretamente proporcional - muitas vezes, uma série de pequenas atividades juntas tem impacto semelhante aos empreendimentos de grande porte e são muito mais difíceis de controlar ou de se exigir medidas compensatórias;

- Considerar a complexidade de qualquer intervenção urbana deve ser premissa obrigatória, pois existe uma relação sistêmica entre as atividades urbanas construídas no tempo e qualquer mudança pode significar impactos negativos no todo.

- Incorporar a ideia de que, onde houver fluxo e renda reunidos, ou onde houver a possibilidade de criar estas condições, o terciário vai encontrar alguma forma de se instalar.

Finalmente, é importante mencionar que, novos tempos exigem novas atitudes para enfrentar os desafios urbanos da contemporaneidade. Faz-se necessário, portanto, romper com o paradigma atual lastreado em instrumentos urbanísticos idealizados quase há um século, e buscar novos caminhos e que deem conta das dinâmicas urbanas atuais, onde o setor terciário tem assumido uma presença cada vez mais forte no cotidiano de nossas cidades. 


\section{REFERÊNCIAS:}

BADARÓ, Ricardo S.C. Campinas, o despontar da modernidade. Campinas: CEAP / PUCCAMP e Centro de Memória / UNICAMP, 1996.

BERNARDO, Rosana Guimarães. Histórico da Ocupação do Solo no Município de Campinas. São Paulo: FAU-USP, 2002. Dissertação de Mestrado.

BORGES, Marília Vicente. O Zoneamento na cidade do Rio de Janeiro: gênese, evolução e aplicação. Rio de Janeiro: IPPUR - UFRJ, 2007. Dissertação de Mestrado.

BURNS, Edward McNall. História Da Civilização Ocidental Volume II. 2.ed. Porto Alegre: Ed. Globo, 1968.

CACHINHO, Herculano. Dos regimes do tempo no comércio da metrópole contemporânea. Palestra apresentada no III Colóquio Internacional sobre Comércio e Cidade. Anais. São Paulo: FAU-USP, 2008.

CAMPOS FILHO, Cândido Malta. Cidades Brasileiras, seu controle ou o caos. 4.ed. São Paulo: Studio Nobel, 2001.

CHOAY, Françoise. O Urbanismo: Utopias e realidades, uma antologia. São Paulo. Perspectiva, 2005.

DUANY, Andres; Plater-Zyberk, Elizabeth; Speck, Jeff. Suburban Nation: The rise of Sprawl and the Decline of the American Dream. New York: North Point Press, 2000. $10^{\text {th }}$ anniversary paperback edition, 2010.

FELDMAN, Sarah. Planejamento e Zoneamento. São Paulo: 1947-1972. São Paulo: Edusp/FAPESP, 2005.

O Zoneamento Ocupa o Lugar do Plano. São Paulo, 1947-1961 in VII encontro Nacional da ANPUR, Recife, 1997.

FERRARI, Celson. Dicionário de Urbanismo. São Paulo: Disal, 2005.

FISCHEL, William. An Economic History of Zoning and a Cure for Its Exclusionary Effects - Ensaio apresentado no Florida State Critical Issues Symposium em 8-9 de novembro de 2001 e revisado em 18 dez 2001, disponível em http://www.dartmouth.edu/ wfischel/Papers/02-03.pdf acesso em 12/Jan/2014

.The Homevoter Hypothesis: How Home Values Influence Local Government Taxation, School Finance, and Land-Use Policies. Harvard University Press. Cambridge, 2001.

GARREFA, Fernando. Shopping Centers: de centro de abastecimento a produto de consumo. São Paulo: SENAC, 2011.

GUERRA, Maria M. P. Eficiência Urbana: Fluxos para o comércio e tempo para o pedestre. Dissertação de Mestrado. São Paulo: FAUUSP, 2015.

HARVEY, David. A produção capitalista do espaço. São Paulo: Annablume, 2005

HIRT, Sonia. Zoned in the USA: The origins and implications of american land-use regulation. Ithaca, New York: Cornell University Press, 2014. $1^{\text {st }}$. Ed.

HOBSBAWN, Eric. A Era do Capital, 1848-1875. Rio de Janeiro: Paz e Terra, 1977. 
JACOBS, Jane. The death and life of great American cities. $50^{\text {th }}$ anniversary edition. New York: Random House, 2011.

MANCUSO, Franco. Las Experiências del Zoning. Barcelona: Editorial Gustavo Gili S. A, 1980.

MELLO, Luís Ignácio R. de Anhaia. Problemas de Urbanismo. Boletim do Instituto de Engenharia, 1929.

MITICA NETO, Hélio. Urbanização em Campinas: mudanças no tecido urbano no entorno da rodovia Dom Pedro I. Tese de Doutorado - FAUUSP, São Paulo, 2008.

NELSON, R.L. The Selection of retail location. Nova York: Dodge,1958.

REIS, Nestor Goulart. Notas sobre urbanização dispersa e novas formas do tecido urbano. São Paulo: Via das Artes/FAUUSP/FAPESP, 2006.

ROCHEFORT, M. Les activités terciaire: leur rôle dans l'organization de l'espace. Tome I. Formes de relations entre activités tertiaires e l'organization de l'espace. Paris: CDU/SEDES, 1976.

ROLNIK, Raquel. A Cidade e a Lei. Legislação, política urbana e territórios na cidade de São Paulo. São Paulo, Studio Nobel / FAPESP, 1997.

SILVA, Paula F. F. : A Expansão Urbana de Campinas através de Condomínios e Loteamentos Fechados: (1974 -2005). EESC - USP. São Carlos, 2008. Dissertação de Mestrado.

SALGUEIRO, Teresa Barata; CACHINHO, Herculano. As Relações CidadeComércio. Dinâmicas de Evolução e Modelos Interpretativos. In: CARRERAS, CarIos; PACHECO, Suzana M. (Orgs.). Rio de Janeiro: Armazém das Letras, 2009.

SANTOS, Antonio da Costa. Campinas, das origens ao futuro: compra e venda de terra e água e um tombamento na primeira sesmaria da Freguesia de Nossa Senhora da Conceição das Campinas do Mato Grosso de Jundiaí (1732-1992). Campinas: Editora da UNICAMP, 2002.

SASSEN, Saskia. As cidades na economia global. São Paulo: Studio Nobel, 1998.

SEMEGHINI, Ulisses C. Do Café à Industrialização: Uma cidade e seu tempo. Campinas: Ed. da UNICAMP, 1991.

SILVER, Christopher. The Racial Origins Of Zoning In American Cities in: Manning Thomas, June and Marsha Ritzdorf, eds. Urban Planning and the African American Community: In the Shadows. Thousand Oaks, CA: Sage Publications, 1997.

SOUZA, Maria Adélia (Org.). A Metrópole e o Futuro - Refletindo sobre Campinas. Campinas: TERRITORIAL, 2008.

TALEN, Emily. City Rules: how regulations affect urban form. Washington: Island Press, 2012

Zoning and Diversity in Historical Perspective, Journal of Planning Histo-

$\overline{\text { ry, } 2012}$ - Versão on-line em:

http//jhp.sagepub.com/content/early/2012/05/14/1538513212444566. Baixado em:

28/03/2013

TOLL, Seymour. Zoned American. New York: Grossman,1969. 
VARGAS, Heliana Comin. Espaço Terciário: O lugar a arquitetura e a imagem do comércio. São Paulo: Editora SENAC, 2001.

. A importância das atividades terciárias no desenvolvimento regional. São Paulo: FAUUSP, 1986. Dissertação de Mestrado.

. Comércio: localização estratégica ou estratégia na localização? São Paulo: FAUUSP, 1992. Tese de Doutorado.

. 0 comércio e os serviços varejistas: Principais agentes e sua inserção urbana. p 77-87. GEOUSP Espaço e Tempo. N 8 FFLCH-USP/Humanitas, dezembro/2000.

. Localização comercial não se define por decreto. São Paulo: FAUUSP, 2015. Ensaio. Disponível em http://www.labcom.fau.usp.br/?p=577 Acessado em 05/10/2015.

Comércio e Cidade: Dinâmicas da Motivação, do Tempo e do Lugar. Palestra de encerramento do Seminário Gestão do Tempo e Apropriação da Cidade. Lisboa: Instituto de Investigação Interdisciplinar. 06/11/2014. Disponível em www.labcom.fau.usp.br/?page id=97. Acessado em 14/11/2015

VARGAS, Heliana Comin; ARAUJO, Cristina Pereira (Orgs.). Arquitetura e Mercado Imobiliário. Barueri: Ed. Manole, 2014.

VILLAÇA, Flávio. Reflexões sobre as Cidades Brasileiras. São Paulo: Studio Nobel, 2012.

. Uma contribuição para a história do planejamento urbano no Brasil, in DEÁK, Csaba, SCHIFFER, Sueli Ramos (Orgs.). O Processo de Urbanização no Brasil. São Paulo: FUPAM / EDUSP, 2010.

WILLIAMS, F. B.The law of city planning and zoning. New York: Mcmillan, 1922. WOLF, Michael A. The Zoning of America: Euclid x Ambler. Lawrence, Kansas: 2008. 


\section{SÍTIOS DA INTERNET:}

https://archive.org/details/metropolitanbui00britgoog acesso em 21/Mar/2015.

CAMPINAS (cidade). Mapas detalhados de zoneamento em:

www.zoneamento.campinas.sp.gov.br acesso em 10/Abr/2013.

. Leis e Decretos: Biblioteca da Sec. Mun. Assuntos Jurídicos:

www.campinas.sp.gov.br/bibjuri , acesso em 11/Abr/2013

Congress of New Urbanism

https://www.cnu.org, acesso em 06/Dez/2015.

Dartmouth University: www.dartmouth.edu acesso em 12/Jan/2014.

dhnet.org: www.dhnet.org.br/direitos/anthist/hamurabi.htm acesso em15/Jan/2014

NOVA YORK (cidade): NYCity Department of City Planning:

http://www.nyc.gov/html/dcp/html/zone/zonehis.shtml acesso em 18/Ago/2013.

Museu da Cidade de Nova York: mcny.org acesso em 19/Mai/2014.

Rio de Janeiro (cidade):

PINHEIRO, Manoel Carlos e FIALHO JR., Renato. Pereira Passos: vida e obra. Coleção Estudos Cariocas. Instituto Pereira Passos. Prefeitura da Cidade do Rio de Janeiro Rio de Janeiro-2006.

http://portalgeo.rio.ri.gov.br/estudoscariocas/download/2376 Pereira\%20Passos\%20 vida\%20e\%20obra.pdf acesso em 22/Mai/2015.

Russel Sage Foundation: www.russelsage.org, acesso em 28/Mar/2013.

Sociedade Ernst May: http://ernst-may-gesellschaft.de/ , acesso em 12/Dez/2015.

Suprema Corte dos Estados Unidos da America: www.supremecourt.gov , acesso em 28/Abr/2014

Sínteses de casos julgados pela Suprema Corte dos Estados Unidos:

BUCHANAN versus WARLEY, 245, U.S. $60 \mathrm{em}$ :

http//supeme.justia.com/cases/federal/us/245/60 ,acesso em 29/Abr/2014.

Village of Euclid, Ohio v. Ambler Realty Co. Em:

https://supreme.justia.com/cases/federal/us/272/365/case.html ,29/Abr/2014.

http://venice.jc-r.net/campi/ghetto.htm acesso em 28/Abr/2014.

Verein Fur Sozialpolitik: https://socialpolitik.de/en/ ,acesso em 14/Mai/2014.

http://www.vitruvius.com.br/revistas/read/arquitextos/09.097/136 acesso em 03/Mai/2014

Wikipedia: https://pt.wikipedia.org/wiki/C\%C3\%B3digo de Hamurabi acesso em 15/Jan/2014. 
ANEXOS 


\section{ANEXO A: Ata de Constituição da Sociedade do Bairro Nova Cam- pinas.}

Fonte: Acervo do $1^{\circ}$ Cartório de Registro de Títulos e Documentos, através do $2^{\circ}$

Registro de Imóveis.

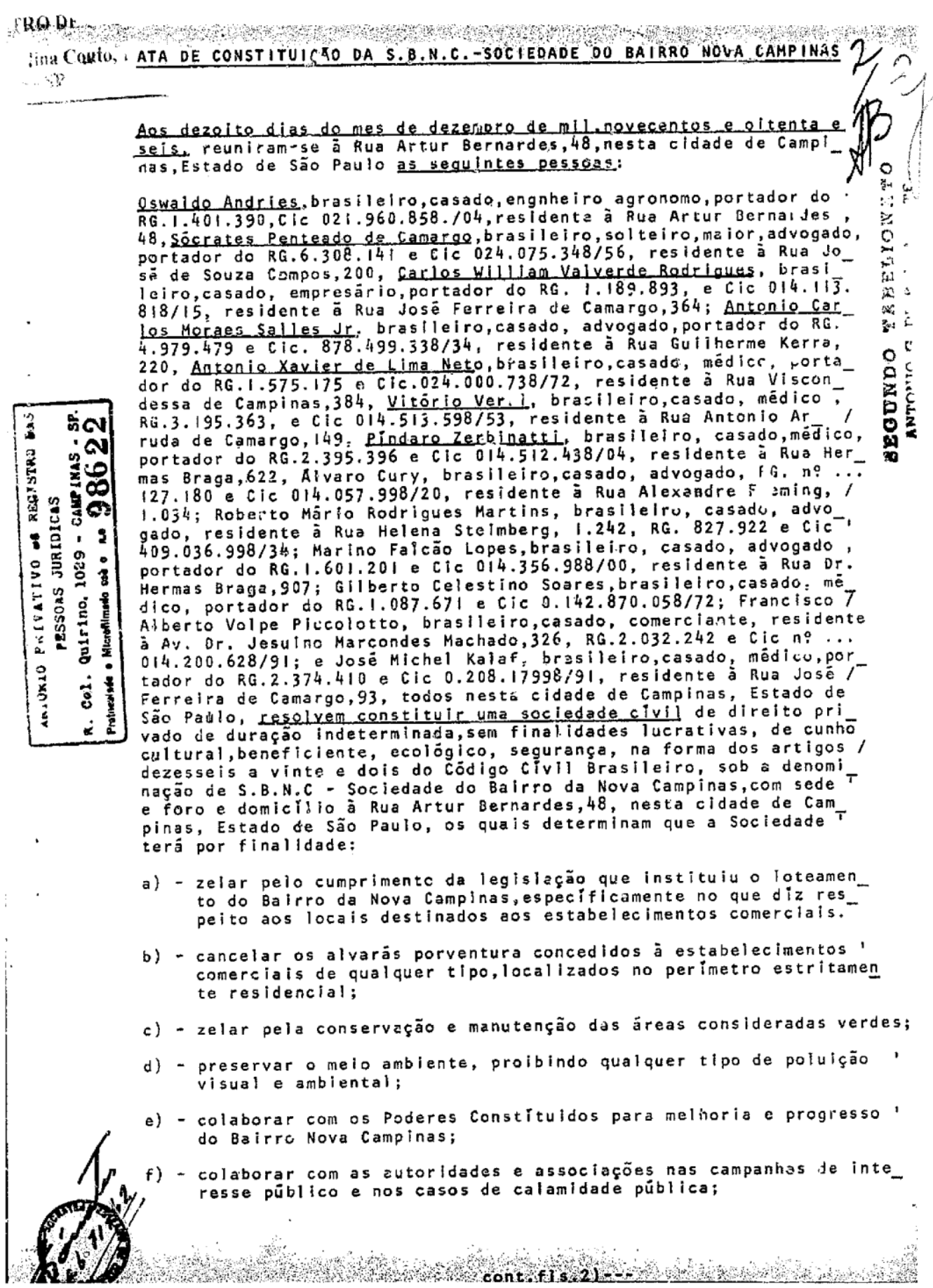




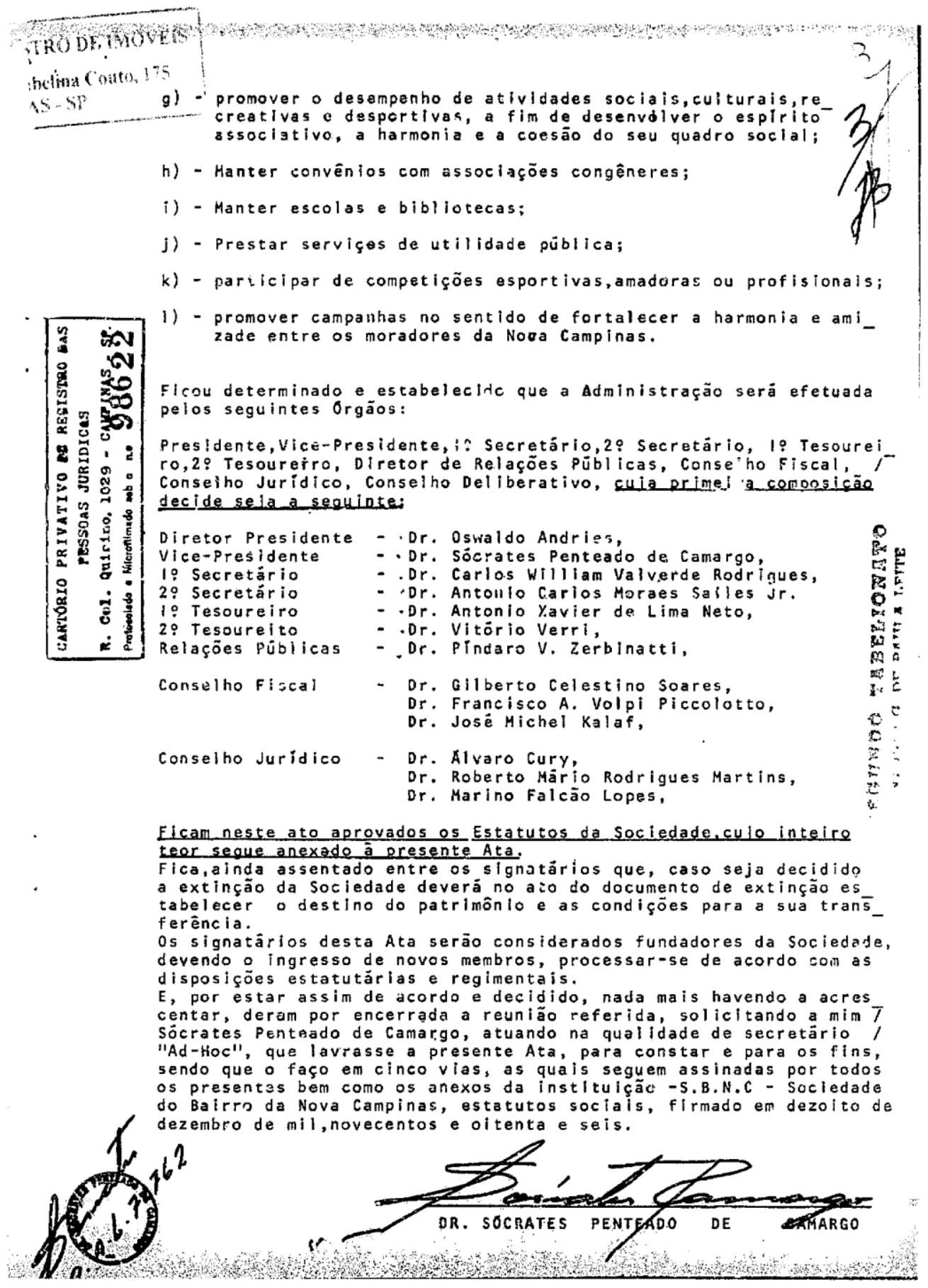



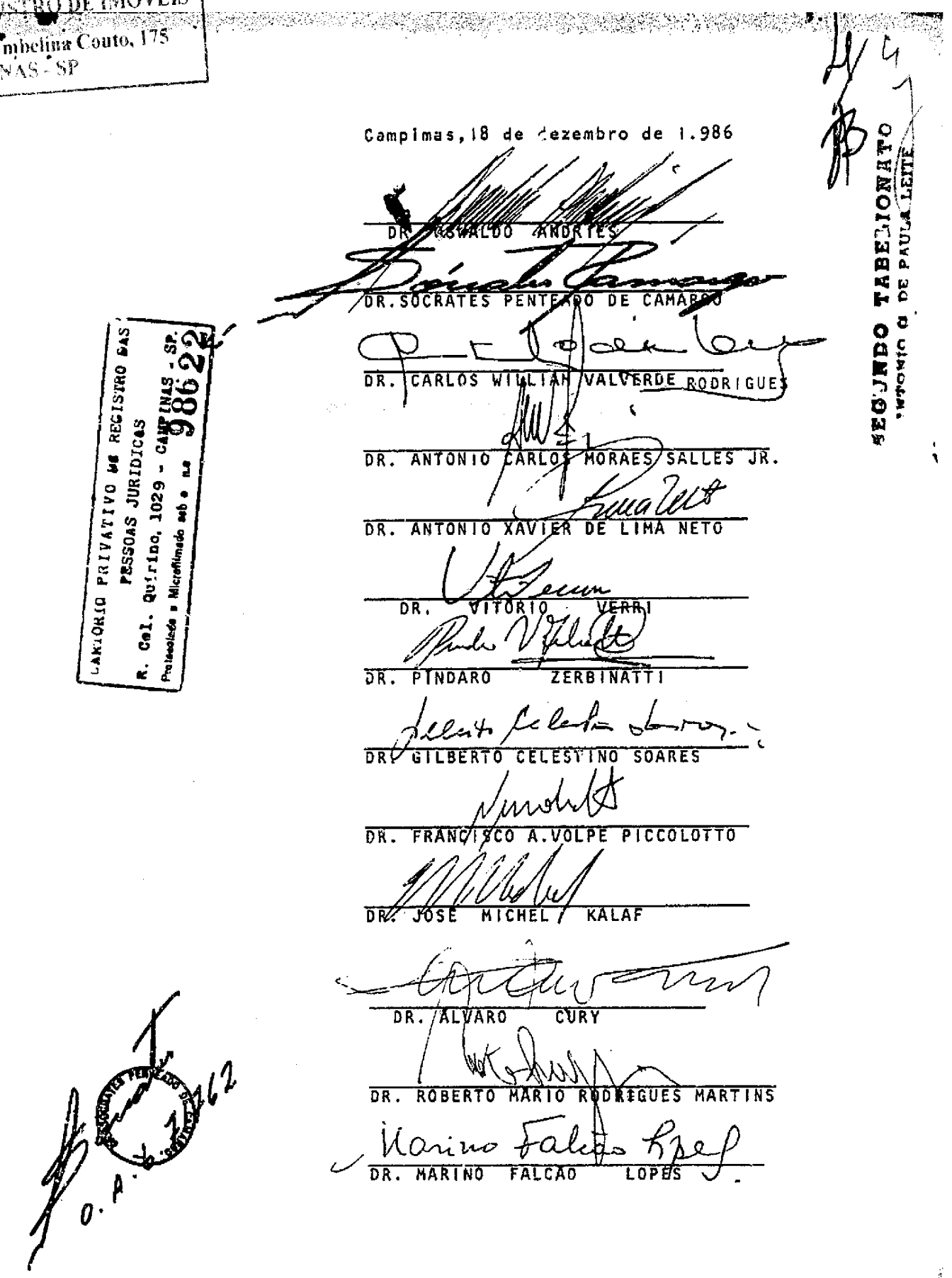

DR. ANTONIO XAVIER DE LIMA NETO

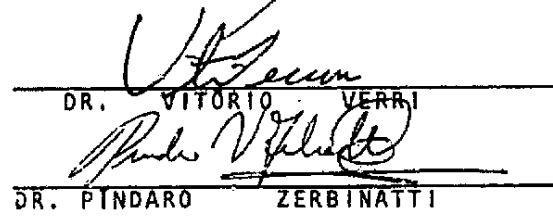

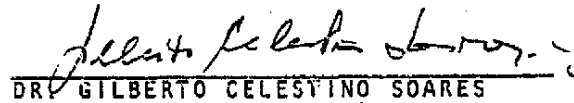
incolde

DR. FRANCTSCO A.VOLPE PICCOLOTTO
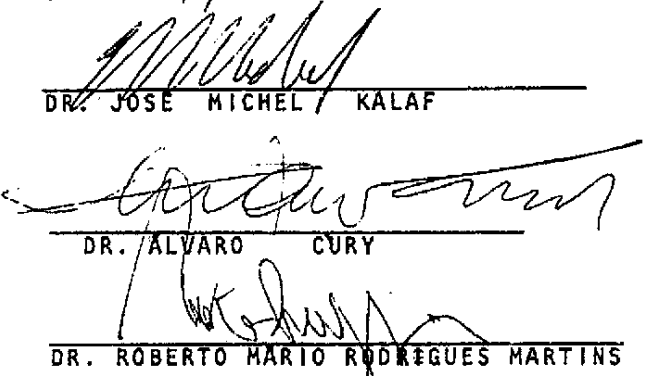

- Karimo faledio haep 


\title{
ANEXO B: Trechos da Audiência Pública sobre o PL 31/2000 que se transformaria na Lei № 10.566/2000 (Transcrição).
}

Fonte: Arquivo da Câmara Municipal, com grifos nossos.

\author{
CÂMARA MUNICIPAL DE CAMPINAS
}

AUDIÊNCIA PÚBLICA (TRANSCRIÇÃO)

$14 / 03 / 2000$

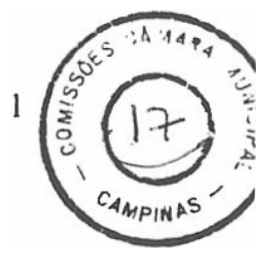

[...] O primeiro projeto a ser discutido é o Projeto de Lei 31 I 00, nós vamos tentar seguir aqui a convocação da Audiência, é o Projeto de Lei $31 / 00$, de autoria, que altera a redação do artigo primeiro da Lei 837, ou melhor 8.737, de 10 de Janeiro de 96. Como o projeto é de minha autoria, eu peço permissão à mesa para fazer um pequeno comentário sobre o projeto e passarei a palavra ao DU. Esse projeto tem por objetivo modificar o artigo primeiro da Lei 8737, de 10 de Janeiro de 1 996, que dispõe sobre a concessão de alvará do uso em edificações existentes em áreas do município de Campinas, zoneamento....zoneados pela Lei 6031 / 88, em Z1 , Z2, Z3, ZS, Z6e Z7 . Estabelece parâmetros construtivos para habitações de interesse social e dá outras providências e passa a vigorar com a seguinte redação: as edificações aprovadas com habite-se, situadas em áreas do município de Campinas, zoneada como Z1, Z2, Z3, ZS, Z6 e Z7, além do uso habitacional permitido pela lei, poderão ser destinadas parcialmente ou totalmente aos usos comercial, institucional, industrial ou de serviços, desde que observadas as condições estabelecidas por esta lei.

A justificativa: a presente proposta visa permitir que os imóveis residenciais localizados nas áreas citadas na lei, mesmo construídos a partir de 96, possam ser utilizados para os fins estabelecidos na Lei 8737 / 96. O que significa isso? Essa lei, a 8737, ela estabelece que nessas zonas poderão ser fornecidos alvarás, desde que o imóvel tenha habite-se até 10/ 06/96. Olha, se pode lá, porque não pode aqui ? Então, nós estamos eliminando essa data. Simplesmente isso. Pode sempre. Quer dizer, os que foram construídos antes de 96 e os que foram construídos depois. Achamos que para o município seria importante, para o usuário seria importante, para a população seria importante e o município só tem a ganhar. Eu acho que nós só vamos arrecadar recursos, vamos tentar dar uma oportunidade para a pessoa que queira montar um pequeno comércio, poder se estabelecer, dar emprego, criar emprego, poder manter a sua familia e, na minha visão não vejo nenhum problema. Para isso, gostaria de passar a palavra ao diretor do DU.

EVERALDO - Boa tarde, senhores vereadores. Quanto ao projeto de lei proposto pelo senhor vereador, nós lá no Departamento de Urbanismo não temos nenhuma observação a fazer, exceto de que esse é um problema com o qual a gente se depara bastante no nosso cotidiano. Por se tratar de questão de zoneamento e destinação de uso, acredito que também, mais importante até do que a posição do DU e da Secretaria de Obras, seja a posição da Secretaria de Planejamento, com referência principalmente à destinação dessas áreas, da classificação das atividades por área. Na nossa parte, quanto à emissão de alvarás, isso daqui ajudaria bastante, eliminaria uma série de problemas que nós temos lá hoje, exatamente porque o cidadão chega e pergunta: qual é a diferença que eu tenho por não estar lá em 96, o que cria essa situação para ele de discriminação.

SELLIM - Consulto a mesa ainda e alguém gostaria de se pronunciar ? Pois não.

ROSÂNGELA - Em relação a esse projeto de lei, o Departamento de Planejamento tem algumas coisas a dizer contra, em função ....só um minutinho....

SELLIM - Tem a palavra Rafful, nobre vereador. [...] 
RAFFUL - Senhor presidente, senhores. vereadores, a emenda de minha lavra, protocolada em 8 de Março, apenas ela também permite que sejam abertos para o comércio, para alguns tipos de servico, algumas ruas de nossa cidade hoje paralisadas pelo artigo, impedidas pelo Artigo 27 da Lei 6031, que apresenta restrições quanto ao uso. São bairros estritamente residenciais, mas que o próprio andamento e o próprio progresso, desde 1988 que nós temos essa lei e não foi alterada. Então, nós pensamos juntamente com nossa assessoria, aliás foi uma falha não ter discutido com a Secretaria de Planejamento antes, mas eu sabia, eu tinha noção da importância dessa audiência, para que nós aqui discutíssemos da viabilidade ou não e de talvez algum acerto nessa emenda para que se permitisse. Hoje, nós temos determinadas áreas...dentro desses bairros estritamente residenciais, nós temos alguns imóveis completamente distorcidos. Nós temos comércios instalados, escritórios que não possuem o devido alvará de funcionamento. A Secretaria de Obras, pelo seu Departamento de Urbanismo, não tem fiscais suficientes para fiscalizar essas irregularidades. Aí, o que nós fizemos? Nós permitimos, abrimos, que nas vias arteriais definidas pela Lei de Polo Gerador de Tráfego, se fosse permitido algum tipo de serviço para que aqueles imóveis não fiquem parados, porque hoje ninguém aluga uma casa para residência na Jesuíno Marcondes Machado, na José Bonifácio, na Heitor Penteado. Então, principalmente nessas vias, a Carlos Stevenson, que

a característica já está alterada. Apenas nós não temos a legalidade da situação, para que a Secretaria de Obras, através do seu departamento competente, forneça os alvarás para essas pessoas. Então, nós temos inúmeras empresas instaladas, eu digo isso com relação à Nova Campinas porque eu moro lá e eu sei de inúmeros imóveis que trabalham de porta fechada e são escritórios de advogados, de médicos, de empresas de telefonia, de empresas de exportação, tudo na Jesuíno, nenhuma delas possui o devido alvará de funcionamento. Então, pensando nisso, nós abrimos para algumas categorias, para que nós aqui pudéssemos discutir a viabilidade ou não. Então, serão permitidos os usos SP 2 - Serviços Profissionais, SL 2 - Serviço de Educação Informal, SG I Servicos Administrativos, Financeiros e Empresariais e SG 5 - Serviços de Esportes. Será também permitida a categoria de uso CL 1 , com excecão de armazéns, empório, mercearia, casas de carne, açougue, avícola, peixaria, quitanda, frutaria, padaria e panificadora. Será também permitida a categoria de uso CL 2, com excecão de bar, lanchonete, pastelaria, aperitivos, petiscos, sucos e refrescos, restaurante, pizzaria, churrascaria, cantina, bazar, armarinhos, aviamentos, casa lotérica, charutaria, tabacaria, confeitaria, doceria, chocolates, sorveteria, casas de massas e pratos prontos quentes ou congelados. Isso está tudo proibido, tá. Ficaria farmácia ou drogaria, farmácia de manipulação, algum tipo de comerc10 que talvez fosse....atendesse mais a situação que aquele bairro apresenta. Então, eu sei que é uma emenda polêmica, que existem moradores favoráveis, contrários, porque está mexendo com alguma coisa já arraigada. Só que nós apresentamos justamente essa emenda, para que nós possamos começar a discutir uma situação que já existe de fato mas não de direito. Parabenizo o vereador Sellim pela sua lei, eu acho que esse projeto de lei vai realmente resolver uma série de problemas que a Secretaria de Obras hoje tem, na regularização dos imóveis que hoje estão com suas atividades distorcidas. E, eu gostaria que a Secretaria de Planejamento analisasse a minha emenda, apoiasse, porque eu sei que é polêmica, eu vou levar pedrada e vou levar beijos, então é uma coisa muito complicada e estamos mexendo num cerne, mas que precisa ser mexido uma hora e, realmente o que nós estamos querendo é provocar essa discussão. Muito obrigado e nós vamos discutir qualquer coisamais.

$[\ldots]$

Doutora....ROSÂNGELA - Eu acho que a diretoria de Planejamento precisaria de um tempo para analisar, porque agora chegou uma emenda e tem questões até jurídicas que eu gostaria de resolver, que seriam exceções à própria categoria de uso, ou seja, foi estabelecida uma categoria de uso e foi excetuada alguns usos dentro dela. Eu não sei se isso juridicamente tem validade. Eu só posso fazer exceções a uma legislação que já excetua. Eu deveria ter algum apoio do pessoal do Jurídico para estar resolvendo esta questão. E a outra questão que vem daquela lei da flexibilização de 96, ela vem num contexto na época que era de imóveis sem condições de aluguel e, enfim, então foi feito para uma data específica. E com essa nova legislação, ela toma isso um ato corrente daqui para frente. Então, isso nos preocupa muito, porque começa a abrir um zoneamento mais genérico. Então, a gente gostaria de um tempo para analisar melhor as duas situações. 
SELLIM - Nós entendemos....pois não, nobre vereador.

RAFFUL - Gostaria que determinasse o prazo para que nós pudéssemos aguardar antes de colocarmos esse projeto em pauta. Então, ficaria determinado, por vai ficar 180 dias como tudo,não vai ficar.

$[\ldots]$

EVERALDO - Eu não tive a oportunidade de falar sobre a emenda. Eu acho que a emenda apresentada pelo vereador Rafful também, traz um.....apesar dessa questão que a Rosângela levanta, eu faço uma observação quanto ao conceito de via arterial, eu acho interessante esse conceito, porque é justamente onde a gente vê se aglutinar essas atividades comerciais, atualmente restringidas pela Alínea d). Acho muito interessante esse conceito porque isso já é uma situação posta no município e a gente corre contra essa situação. Toda vez que alguém, algum cidadão procura o DU para regularizar e tem o seu pedido negado, ele me traz fotos, ou seja, ele faz uma denúncia indireta de toda a vizinhança dele, isso gera um problema terrível porque eu não posso ficar omisso, eu não posso deixar de intimar todos os vizinhos que estão lá, então é uma coisa, um conceito bastante interessante da via arterial.

$[\ldots]$

SELLIM. - Com a palavra o nobre vereador Aurélio Cláudio.

AURÉLIO - Eu concordo com o vereador Rafful, apenas discordo na seguinte questão, que ele diz sobre a questão de vetar ou aprovar, o CMDU e a Secretaria de Planejamento. Eu acho que o CMDU e a Secretaria de Planejamento, por ser um órgão específico, eles deveriam estar à frente dos vereadores e já resolver essa questão, não deixar para os vereadores, resolver isso. Por exemplo, na minha região, na minha região Oeste, existe uma grande quantidade de comércios que nasceram naturalmente, devido à demanda, devido à necessidade da minha região e que se encontram totalmente irregulares. E se não é o vereador que está lá próximo resolver, ninguém vai resolver. Então, é essa questão da Avenida Ibirapuera, que estava em pauta até então. É apenas um dos casos, existem dezenas e dezenas, que deveria o órgão específico ou o órgão auxiliar específico, estar resolvendo, sem a necessidade de ter um vereador intermediando no caso.

RAFFUL - Mais uma coisa. Eu sugiro também, eu não sei da estrutura das diversas secretarias, para que os técnicos da Secretaria de Planejamento, saíssem um pouco de trás do vidro e fossem às ruas para sentir na pele a situacão. Aliás, eu tenho uma sugestão a fazer. Porque que a Secretaria de Planejamento não trabalha juntamente com a Secretaria de Obras e se coloque alguém da Seplama dentro do DU, para que acompanhe par e passo os problemas que o cidadão de Campinas tem, o problema que a Secretaria de Obras possui, eu sou extremamente favorável a um trabalho em conjunto, alguém... é uma luta minha antiga, que eu não consigo enfiar $n a$ cabeça do dirigente. Alguém do Planejamento desce até a Secretaria de Obras, fique no OU, acompanhe par e passo, hoje nós temos a Renata. A Renata abriu a mente dela porque ela está sentindo a dificuldade que é o trabalho do diretor do DU. 0 que vem de...o vereador hoje no caso é um despachante de luxo, para tentar quebrar os galhos que a Prefeitura não resolve. Esse é o nosso papel. O Aurélio está certo, eu acho que as secretarias têm que trabalhar em Conjunto . Isso é administração moderna, não ficar atrás do vidro, querendo uma Dinamarca, onde existe uma Calcutá hoje.

[...]

SELLIM - Obrigado, Dr. Marcelo, eu queria esclarecer, até foi importante esse diálogo aqui hoje entre CMDU, representantes do Executivo e vereadores. Na verdade, o vereador nunca tenta mudar um zoneamento por sua livre e espontânea vontade. Sempre chega a ele, não só a ele, a todos os vereadores e de repente um resolve apresentar o projeto. Nós trabalhamos sob uma pressão da população muito grande hoje, em funcão de uma lei que está aí há 12 anos. E Campinas de 12 anos atrás, ela mudou muito. Então, temos uma lei que cria o Plano Diretor, que foi criado em algumas regiões, mas que não foi criado na região do Campo Grande, na região do Ouro Verde, que vem sendo estudado desde 92. Quer dizer, em 92, a Prefeitura contratou um estudo da Pucc, da Unicamp, apresentaram 
um livro desse tamanho assim, quer dizer, um livro bonito e tal e hoje está sendo feito um outro convênio com a Pucc e a Unicamp para reestudar novamente a região do Campo Grande e do Ouro Verde porque não se conseguiu ainda incluir no Plano Diretor da cidade. Então, o vereador, que participa na fila do ônibus, na fila da padaria e tal, ele é o primeiro a ser cobrado e aqui às vezes forma fila nos gabinetes dos vereadores, para discutir o mesmo assunto. E não é possível uma região como, por exemplo, o Santa Cândida, que está cheio de barracões, cheio de lugar que quer, cheio de gente que quer montar empresa e não consegue. $\mathrm{E}$ outras avenidas da cidade, como a própria Heitor Penteado hoje, que você vai lá tem umas 12 casas para alugar, porque ninguém aluga para residência e não se pode montar nada. Então, eu aproveito aqui a presença do nosso secretário e de todos os membros da mesa, não é porque estão presentes, mas vêm desenvolvendo um grande trabalho no Executivo, com uma outra visão, que com certeza não vai levar mais 4 anos para mudar esse Plano Diretor $d a$ região do Ouro Verde, da região do Campo Grande, para que ....o vereador apresenta o projeto porque lhe é solicitado, lhe é cobrado, lhe é pedido e às vezes até briga aqui tem saído na platéia lotado de gente, fazendo pressão, para o cidadão poder montar uma pequena empresa. Tivemos o caso aqui do cidadão que quer montar uma fábria de biscoito, que emprega 100 pessoas, ele chorou aqui. Primeiro ele brigou, primeiro ele xingou, depois ele viu que perdeu, acabou chorando. Então, essa é a atividade do vereador. Não é porque ele quer ou porque ele tem um interesse. É porque a população chega aqui, quer montar o seu pequeno comércio, a sua pequena indústria e não consegue e, sabendo que, qualquer um que fosse ver in loco, autorizaria ele montar. Com a palavra o nobre vereador Sebastião Arcanjo.

SEBASTIÃO - Eu só queria registrar aqui senhor presidente, que nem todos são tratados dessa maneira. Alguns têm tratamento privilegiado. Nós estamos dando exemplo da fábrica de biscoito lá na região do Campo Belo, que tem questões do ponto de vista até da ampliação do Aeroporto de Viracopos, que deve ser considerado na análise. Mas, por outro lado nós temos também um shopping aqui na Avenida Brasil, que foi pouco discutido pelo menos no órgão que eu represento nessa Câmara, na Comissão de Polos Geradores e está funcionando em plena atividade. Tem a Unip, ali na Zona Sul, do lado do Jumbo Extra, que.também funciona e com exceções e hoje inclusive foi objeto de debate na nossa reunião da Comissão. Então, o que tem aqui na cidade de Campinas é um tratamento diferenciado, entendeu. Algumas pessoas têm um tratamento vip, outros têm um tratamento de terceira ou de quarta categoria. Nós precisamos tratar a todos de maneira igual na cidade de Campinas.

[...]

Agora, a responsabilidade de pensar a cidade do ponto de vista estratégico é da Prefeitura, do Executivo, da Secretaria de Planejamento. Isso nós estamos falando desde 97, a primeira vez que ocupamos a tribuna para discutir, eu pessoalmente assumi em 97 aqui, para discutir o primeiro pré-zoneamento. E até hoje, nós estamos no terceiro secretário do Planejamento na cidade de Campinas e nós não fizemos um debate sério sobre planejamento, desenvolvimento urbano na cidade de Campinas. Então, a questão que se coloca é para quem que nós vamos dirigir a nossa critica. Para aqueles que estão participando até voluntariamente dos conselhos, para aqueles que querem organizar uma atividade econômica na cidade, daí que entra muitas vezes entra em contradição com a legislação, para aquela situação que o presidente se referiu, em regiões que foram pensadas para cumprir...para uma vocação, algumas estritamente residenciais como a região do Ouro Verde e Campo Grande que, até em função de razões de natureza econômica que aconteceram no nosso País e na cidade, acabaram adquirindo outra vocação e que num projeto articulado e pensado é necessário rever qual que é a vocação dessas regiões. $O$ Distrito Industrial falido, 0 Aeroporto amplia, não amplia, a região do Campo Grande sem uma vocacão ainda estabelecida e as pessoas precisam viver lá. Precisam de transporte, qualidade de vida e de serviços. $\mathrm{E}$, a Prefeitura de Campinas é que tem que se responsabiliz.ar. A Prefeitura de Campinas, o chefe do Executivo, a Secretaria de Planejamento, na pessoa aí, dirigindo, espero que o secretário tenha êxito e consiga que a gente num futuro próximo estar retomando a essa discussão, que de fato chame a cidade para discutir, faça uma conferência, chame as entidades, os conselhos de participação e vamos 
discutir o que nós temos na cidade de Campinas, que tipo de cidade nós queremos para o nosso futuro. E a partir daí quem sabe, nós não tenhamos que estar aqui resolvendo situações pontuais que algumas delas são legítimas, são justas, mas muitas delas são carregadas de dúvidas, de dúvidas com relação inclusive a negócios que estabelece. O vereador Rafful tem razão, nós não somos despachantes de luxo aqui, eu rejeito o rótulo de despachante de luxo, mas infelizmente às vezes, nos cumprimos...nos deixamos a cumprir um papel subalterno e que nos coloca muitas vezes rótulos que acaba generalizando, porque às vezes você tem que fazer uma intervenção, que é correta, mas tem muita coisa que se faz nesta cidade, mal intencionada. Se adquirem lotes grandes em áreas que não tinham do ponto de vista legal, a vocação para determinado tipo de comércio ou de indústria e depois se articula na Câmara, pressiona o vereador e a gente vota infelizmente, na calada da noite um tempo atrás, ou agora vêm aqueles pacotões de final de ano. Esse ano muito mais grave ainda porque é um ano eleitoral e as acusações sobre nós devem ser muito maiores ainda. Então, para tirar esse caráter subjetivo das discussões que nós estamos fazendo aqui, era necessário que nós, a Secretaria de Planejamento, o prefeito com a autoridade que lhes convém, que lhes tem e que a Lei Orgânica os assegura, porque muitas questões que nós resolvemos aqui inclusive entram em contradição com a Lei Orgânica, são matérias que os vereadores inclusive não poderiam nem estar discutindo e a gente coloca para às vezes até provocar o debate, sabendo que são ilegais, está certo, mas alguém tem que chamar para si a responsabilidade, porque aí significa não só a ausência de um planejamento estratégico mas, principalmente, a ausência de governo . Isso é mais grave porque aí a cidade se orienta por si própria e depois nós temos que corrigir alguns casos, outros impossibilitar que as pessoas tenham o direito de regularizar o teu local de moradia e outros acertar...acertar, literalmente esse é o termo, situacões que são inadequadas, injustas e que a Prefeitura tinha que aí sim exercer a .Lei e proibir que funcionasse porque são negócios ilícitos que se articulam por debaixo do pano muitas vezes ou aproveitando contradiç̃oes que existem na legislação em Campinas. SELLIM - Eu só queria esclarecer, especialmente para os membros da Mesa, que essa crítica não cabe só a vocês, eu sou vereador há 12 anos e há 12 anos eu venho discutindo o mesmo assunto. Quer dizer, o nobre vereador está aqui desde 97, eu estou desde 89 e outros vereadores que estão comigo desde 89, desde 89 nós estamos discutindo o mesmo assunto. Quer dizer, essa crítica não cabe só a essa administração. Quer dizer, cabe que não houve um planejamento na cidade há muito tempo. Agora se fala para um planejamento 2010, tomara que tenha. Só gostaria de esclarecer isso. $[\ldots]$ 
ANEXO C: Reportagens do Jornal Correio Popular de 24/08/2000 e 12/09/2000, sobre a polêmica da Lei 10.566/00 e a instalação de usos terciários na Nova Campinas.

Fonte: Acervo da Família Brásio.

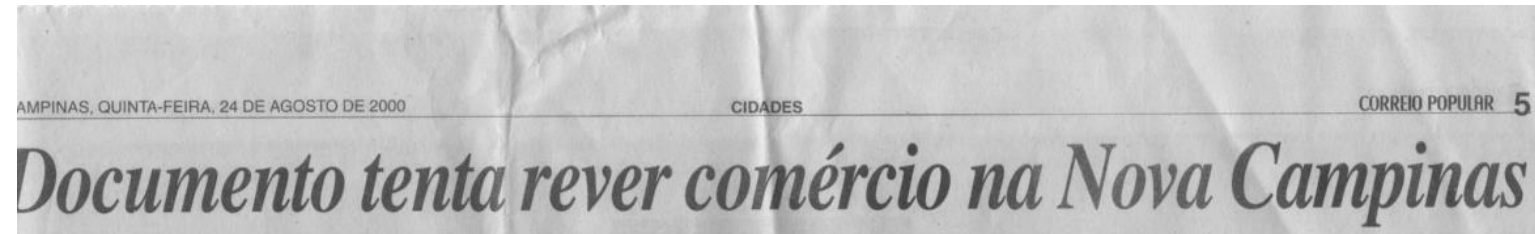

baixo-assinado é entregue à Câmara e ao prefeito Chico Amaral (PPB); vereador diz que vai apresentar novo projeto

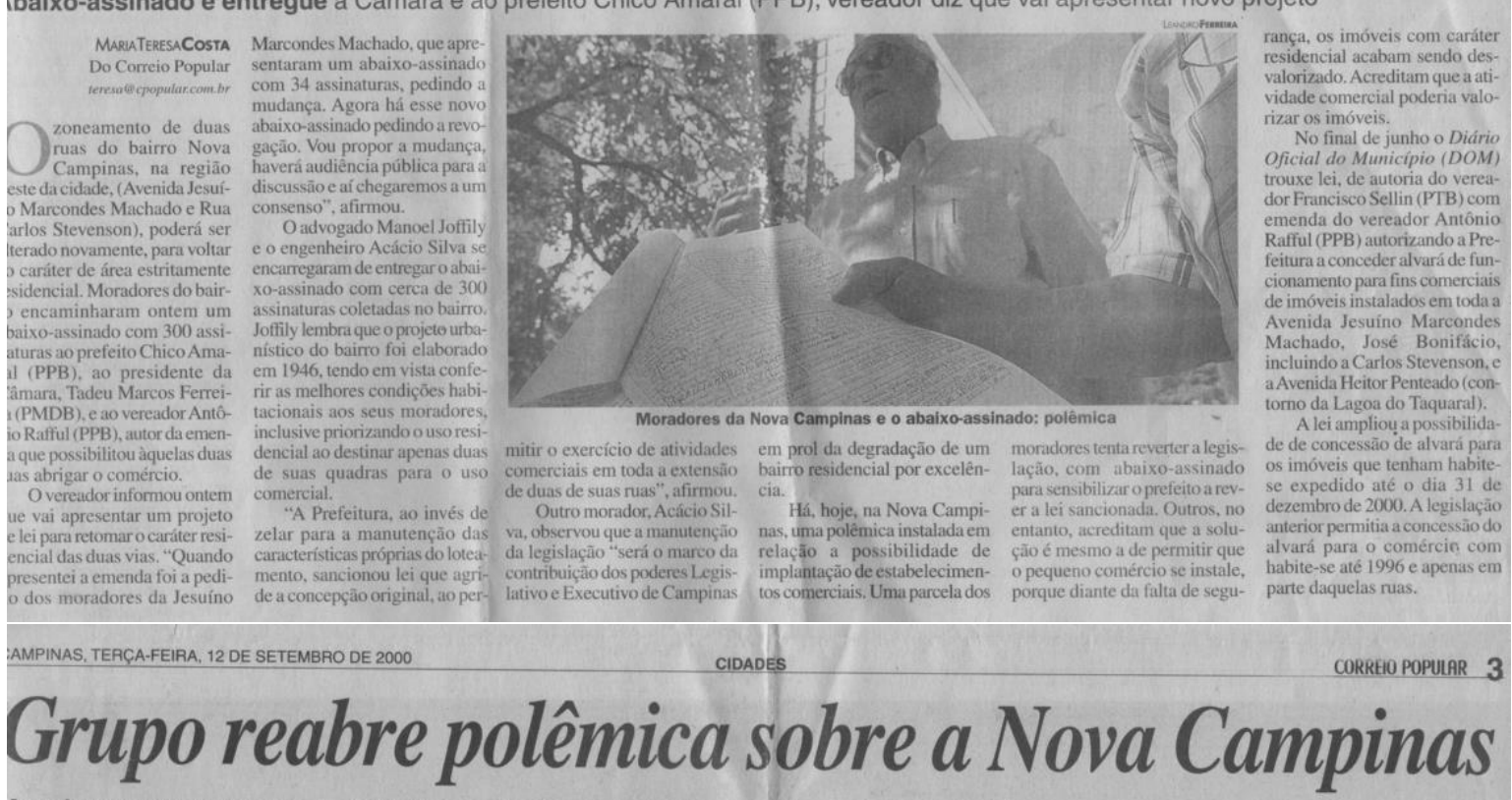

Aoradores entregam na Câmara abaixo-assinado que pede liberação do comércio em todo bairro, em proposta que vem sendo rejeitada

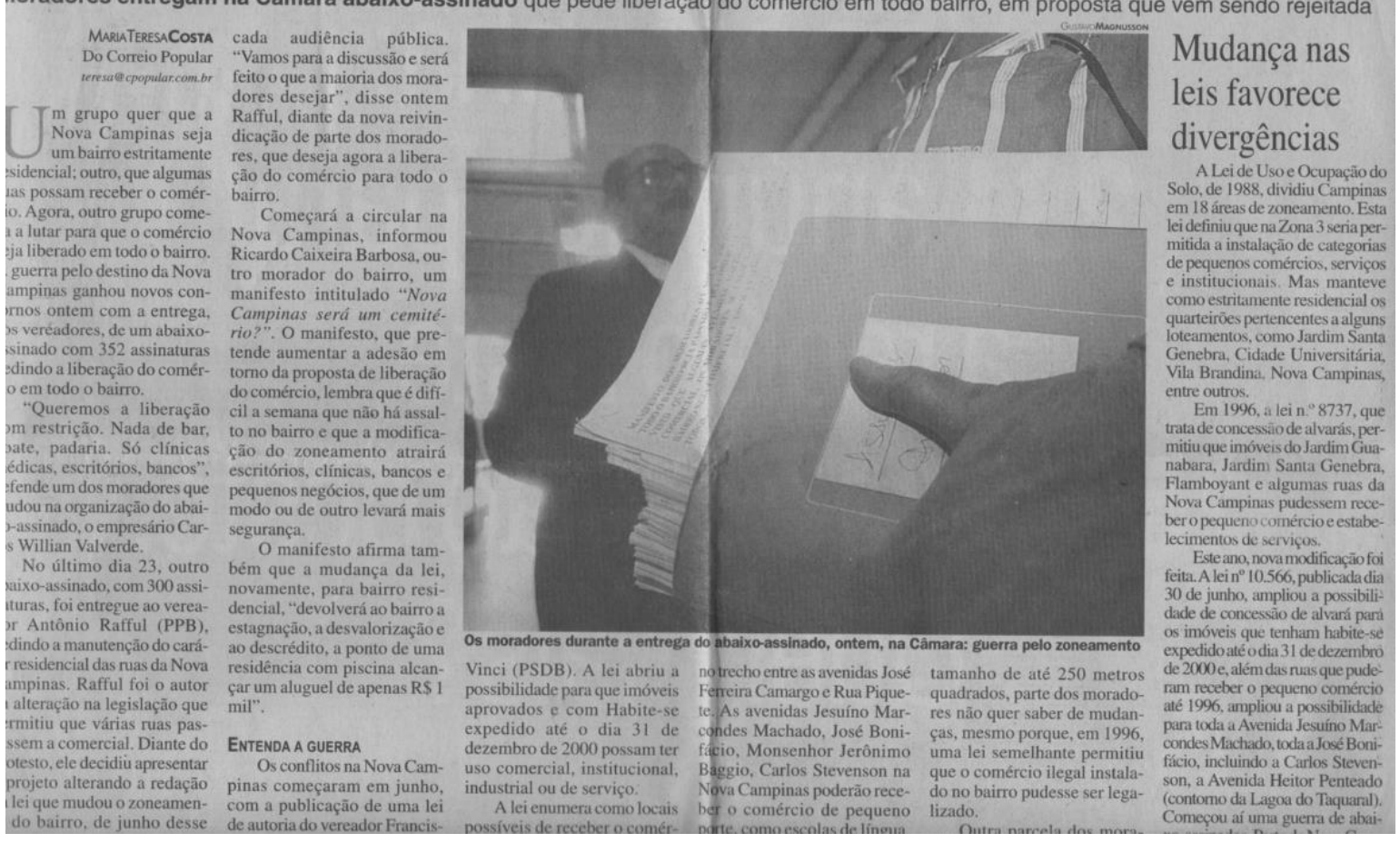

